FABIO MALINA LOSSO

\title{
OS DIREITOS AUTORAIS NO MERCADO DA MÚSICA
}

Tese apresentada ao Programa de Pós-Graduação da Faculdade de Direito da Universidade de São Paulo como requisito parcial para a obtenção do grau de Doutor em Direito Civil.

Orientador: Prof. Titular Fabio Maria De-Mattia

Faculdade de Direito da Universidade de São Paulo

São Paulo

2008 
FABIO MALINA LOSSO

OS DIREITOS AUTORAIS NO MERCADO DA MÚSICA

Faculdade de Direito da Universidade de São Paulo

São Paulo

2008 
Dedico esta tese

À minha Thaisinha, companheira de todos os momentos, fonte de minha inspiração.

Aos meus queridos pais, Arlene e Ezequias, exemplos de amor. 


\section{AGRADECIMENTOS}

Ao meu orientador, Professor Fabio Maria De-Mattia, profundo especialista em direito autoral, pelos valiosíssimos ensinamentos e invulgar gentileza.

Ao Prof. Dr. Alcides Tomasetti Jr., pelas lições nas disciplinas de pós-graduação e pelas importantes contribuições durante e após o Exame de Qualificação.

À Prof. ${ }^{a}$ Dr. ${ }^{a}$ Lídia Reis de Almeida Prado, pelas lições na disciplina de pós-graduação e contribuições no Exame de Qualificação.

Ao Prof. Dr. Rodrigo Xavier Leonardo, pela amizade e disponibilidade para a troca de idéias sobre temas de direito e de música, os quais domina com precisão. 
A cena musical como a vejo hoje é pouco diferente de quando eu estava crescendo. Os percentuais são aproximadamente os mesmos: 95\% de lixo e 5\% puro.

Contudo, os sistemas de marketing e distribuição estão no meio de uma enorme guinada, e por volta do final desta década creio ser improvável que qualquer uma das atuais gravadoras ainda esteja no negócio. Com todo o respeito a todos os envolvidos, isso não seria uma grande perda. A música sempre vai achar um caminho até nós, com ou sem negócios, política, religião ou qualquer outra baboseira ligada a ela. A música sobrevive a tudo e, como Deus, está sempre presente. Não precisa de ajuda, e não é obstruída. Ela sempre me encontrou e, com a bênção e permissão de

Deus, sempre haverá de encontrar

(CLAPTON, Eric. A autobiografia. Trad. Lúcia Brito. São Paulo: Planeta do Brasil, 2007. p.394). 


\section{RESUMO}

A presente tese parte da constatação de que diversas crises nos direitos autorais impactaram o mercado da música, todas coincidentes com a introdução de novas tecnologias. Com o advento das tecnologias digitais de fixação de obras musicais e da internet, passou-se a questionar se o momento atual permite identificar uma autêntica crise no direito do autor e, a partir disso, como se pode refletir sobre as questões decorrentes das novas tecnologias que, fatalmente, são pensadas com as velhas normas e teorias. São linhas essenciais do trabalho: a) a criatividade musical e o impacto de diferentes tecnologias para sua fixação e distribuição; b) a criatividade musical e o reconhecimento e a proteção de direitos do criador; c) a inflexão entre os interesses do criador e os outros diversos sujeitos envolvidos na fixação e distribuição da obra artística musical ao lado do interesse dos destinatários; d) a pluralidade de soluções para definir os moldes dessa inflexão e as direções tomadas pelo direito brasileiro. Verifica-se, no decorrer do presente estudo, a existência de conflito de interesses entre o investidor cultural, o compositor e o consumidor, que se projeta no conflito entre os direitos autorais e o direito de acesso aos bens culturais. A conformação de ambos constitui um relevante desafio trazido pelos novos tempos da chamada "sociedade da informação", na qual a música digital está inserida.

Palavras-chave: Direito autoral, música, mercado fonográfico, internet, novas tecnologias. 


\begin{abstract}
The present thesis parts from the affirmative that many crises in copyright impacted the music market, all coincident with the introduction of new technologies. With the advent of digital technologies for the fixation of musical works and of the internet, it was questioned whether the present moment permits identification of an authentic crisis in copyright, and, from that, how is it possible to reflect about the issues due to the new technologies that, fatally, are thought according to old laws and theories. The essential guidelines of the thesis are: a) musical creativity and the impact of different technologies for its fixation and distribution; b) musical creativity and the acknowledgement and copyrights protection; c) the inflexion between the author's and other people's, who are involved in the fixation and distribution of artistic musical works, interests contrasted with the interests of the addressees; d) the plurality of solutions to define the molds of this inflexion and the directions taken by Brazilian law. It is verified, throughout the present study, the existence of a conflict of interests between the cultural investor, the composer and the consumer, that projects itself on the conflict between copyrights and the right to access cultural assets. The conformation of both constitutes a relevant challenge brought by the new times of what is called "information society", in which digital music is inserted.
\end{abstract}

Keywords: Copyright, music, phonographic market, internet, new technologies. 


\section{RIASSUNTO}

La presente tesi parte dalla constatazione che diverse crisi nel diritto d'autore, impattano il mercato della musica, tutte coincidenti con l'introduzione delle nuove tecnologie. Con l'avvento delle tecnologie digitali di fissazione delle opere musicali e della Internet, si è passato a questionare se il momento attuale permette identificare una autentica crisi nel diritto dell'autore e, a partire da ciò, come si può riflettere sulle questioni causate dalle nuove tecnologie che, fatalmente sono pensate come le vecchie norme e teorie. Sono linee essenziali del lavoro: a) la creatività musicale e l'impatto musicale delle differenti tecnologie per la sua fissazione e distribuzione; b) la creatività musicale e il riconoscimento e la protezione dei diritti del creatore; c) l'inflessione fra gli interessi del creatore e gli altri diversi soggetti coinvolti nella fissazione e distribuzione dell'opera artistica musicale al fianco dell'interesse dei destinatari; d) la pluralità delle soluzioni per definire i modelli di questa inflessione e le direzioni prese dal diritto brasiliano. Si verifica, a partire del presente studio, l'esistenza di conflitto di interessi fra l'investitore culturale, il compositore e il consumatore, che si progetta nel conflitto fra i diritti d'autori e il diritto all'accesso ai beni culturali. La conformazione di entrambi costituisce una sfida rilevante tratta dai nuovi tempi della chiamata "società dell'informazione", nella quale la musica digitale sarà introdotta.

Parole-chiave: Diritto d'autore, musica, mercato fonografico, internet, nuove tecnologie. 


\section{SUMÁRIO}

INTRODUÇÃO

CAPÍTULO 1 - AS EVOLUÇÕES TECNOLÓGICAS E AS CRISES DO DIREITO AUTORAL NA MÚSICA.

1.1 A MÚSICA NA LEI N. ${ }^{0} 9.610 / 98$................................................................ 12

1.1.1 O Objeto da Proteção Autoral na Obra Musical................................................ 12

1.1.2 Os Sujeitos de Direitos Autorais na Música...................................................... 17

1.1.3 O Conteúdo Dúplice do Direito de Autor...……………………………………. 19

1.1.4 As Exceções aos Direitos Autorais................................................................... 24

1.1.5 A Dicotomia dos Sistemas de Proteção aos Direitos Autorais: Continental versus copyright ...................................................................................... 27

1.2 A INSTALAÇÃO DA INDÚSTRIA FONOGRÁFICA........................................ 31

1.2.1 A Primeira Crise: A Invenção dos Meios de Fixação de Sons ............................ 32

1.2.2 A Segunda Crise: A Radiodifusão...................................................................... 43

1.3 O PÓS-GUERRA: O "OLIMPO" DA INDÚSTRIA FONOGRÁFICA................ 51

1.3.1 A Instituição dos Direitos Conexos: a Convenção de Roma................................. 54

1.3.2 A Terceira Crise: a Fita-Cassete ....................................................................... 57

1.4 A QUARTA CRISE DO DIREITO AUTORAL NA MÚSICA: O SURGIMENTO DO COMPACT DISC (CD) ............................................................. $\quad 65$

1.4.1 O Relançamento, pelas Gravadoras, de Fonogramas do "Catálogo" no "CD" ....... 66

1.4.2 A Popularização do CD Regravável: O Prenúncio do Declínio da Indústria Fonográfica nos Moldes Tradicionais ........................................................... 74

CAPÍTULO 2 - A ATUAL CRISE DOS DIREITOS AUTORAIS NA MÚSICA..... 81

2.1 INTERNET E DIREITOS AUTORAIS: NOTAS INTRODUTÓRIAS................ 81

2.2 A INTERNACIONALIZAÇÃO DO DIREITO AUTORAL NA MÚSICA ......... 85

2.3 O PARADIGMA DIGITAL: APROFUNDAMENTO DA INTANGIBILIDADE DO BEM IMATERIAL............................................................................. 88

2.4 A DISTRIBUIÇÃO DE OBRAS MUSICAIS ……………………………….... 101

2.5 A EDIÇÃO MUSICAL ………………………………………………….... 109

2.6 A EXPLORAÇÃO DO MERCADO FONOGRÁFICO DIGITAL PELA

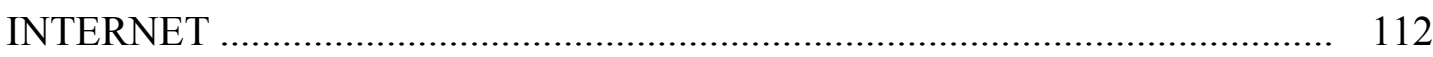

2.6.1 O Desenvolvimento de Tecnologias de Compressão de Dados ........................ 112 
2.6.2 A Aquisição de CD's pela Internet

2.6.3 A Distribuição de Obras Musicais Digitais pelos Digital Music Shops (ou as Lojas Virtuais)

2.6.3.1 Sítios nacionais de distribuição de música

2.6.3.1.1 O caso dos aparelhos leitores portáteis de música digital e os sítios brasileiros de distribuição de música

2.6.3.2 Os sítios estrangeiros de distribuição de músicas.

2.6.4 As "Rádios" On-Line 132

2.6.5 A Transmissão de Arquivos Digitais pelas Redes Ponto-a-Ponto.

2.6.5.1 Aspectos jurídicos do compartilhamento de músicas pelas redes ponto-aponto

CAPÍTULO 3 - DIREITOS AUTORAIS VERSUS DIREITO DE ACESSO AOS BENS CULTURAIS: TENDÊNCIAS E PROPOSTAS.

3.1 DA INDÚSTRIA FONOGRÁFICA AO MERCADO MUSICAL: NOVAS FORMAS DE UTILIZAÇÃO DA OBRA MUSICAL ......................................... 152

3.1.1 Os Sítios de Relacionamento ....................................................................... 156

3.1.2 Os Aparelhos de Telefonia Celular ................................................................ 166

3.1.3 Podcasts, Rádios On-Line e Jogos Eletrônicos ................................................ 176

3.2 OS MECANISMOS TECNOLÓGICOS DE PROTEÇÃO AOS DIREITOS AUTORAIS - DRMs

3.2.1 Os DRMs e o Novo Paradigma dos Direitos Autorais na Música Digital 196

3.3 PROPOSTAS VISANDO À CONFORMAÇÃO DOS INTERESSES EM JOGO..... 205

3.3.1 Breve Análise das Propostas em Face dos Desafios Impostos pela Evolução Tecnológica 


\section{INTRODUÇÃO}

O segmento de mercado musical atravessa momento de profunda crise que, segundo representantes da indústria fonográfica, é causada pela pirataria de obras musicais pela internet. Chega-se a afirmar que tal crise é a mais severa já havida e pode, num cenário extremo, vir a extinguir a produção musical.

O presente estudo objetiva avaliar em que medida essa premissa, já tão fortemente incutida no "senso comum" por meio de artigos jornalísticos e campanhas de marketing da indústria fonográfica, é verdadeira. Em vista da inafastável correlação entre direitos autorais e música, buscar-se-á, também, verificar de que modo a legislação autoral é atingida - ou atinge - os interesses em jogo e se adequa a acompanhar a evolução tecnológica.

Nesse aspecto, cada evolução tecnológica pode ser entendida como provocadora de uma crise e, de fato, conforme será visto no decorrer da presente tese, no que concerne aos direitos autorais na música isso é recorrente.

No conhecido dicionário de filosofia de Gerard Legrand ${ }^{1}$, apresentam-se diferentes sentidos para o termo "crise":

\footnotetext{
(Do grego Kraisis, julgamento de uma disputa, fase decisiva de uma doença, faculdade de discernimento).

$\mathrm{Na}$ ordem científica fala-se de crise quando as noções sobre que assenta uma disciplina ou uma teoria são postas em questão.

$\mathrm{Na}$ ordem psicológica ou moral, há igualmente crise quando o sujeito descobre (ou corre o risco de descobrir) que as motivações habituais, conscientes ou não, da sua conduta não the parecem suficientes e que sofre com esta contradição. No que tem de específico, o pensamento filosófico ignora a noção de crise; esta só pode intevir na possibilidade do discurso como sinal de crises exteriores, que a filosofia é sempre livre de admitir ou recusar de acordo com as suas vias específicas, podendo a admissão eventual ter lugar de dois modos (perturbação, anexação) cujo jogo reinsere o pensamento filosófico no conjunto do devir histórico, mas não pode com isso implicar a sua submissão às instâncias desse mesmo devir.
}

Sob o enfoque na acepção de crise pelo risco, surgem, como problematizadoras desse estudo, as seguintes questões: o momento atual permite identificar uma autêntica crise no direito do autor? Ante uma resposta afirmativa ou negativa, como se pode refletir sobre as questões decorrentes das novas tecnologias que, fatalmente, são pensadas com as velhas normas e teorias?

1 LEGRAND, Gerard. Dicionário de filosofia. Lisboa: Edições 70, 1986. p.102. 
A partir dessas considerações, convida-se o leitor a refletir sobre as linhas essenciais do trabalho: a) a criatividade musical e o impacto de diferentes tecnologias para sua fixação e distribuição; b) a criatividade musical e o reconhecimento e proteção de direitos do criador; c) a inflexão entre os interesses do criador e os outros diversos sujeitos envolvidos na fixação e distribuição da obra artística musical ao lado do interesse dos destinatários; d) a pluralidade de soluções para definir os moldes dessa inflexão e as direções tomadas pelo direito brasileiro.

Para tanto, no Capítulo 1 são analisadas as diversas crises havidas no direito autoral na música, mediante as sucessivas evoluções tecnológicas, no decorrer do século passado, desde a invenção dos meios de fixação até a introdução do meio digital de fixação Compact Disc, passando pela importante distinção entre os sistemas protetivos dos direitos autorais: o latino-germânico e o do copyright, que será de muita importância para o desenvolvimento dos capítulos seguintes. Se perceberá que as crises foram causadas por avanços tecnológicos motivadores de sucessivos réquiens do direito autoral, mas que, a cada nova situação, a legislação internacional sobre a matéria era alterada, seguida pelos diplomas nacionais.

No Capítulo 2, o enfoque recai na análise da atual crise do direito autoral na música, a partir da utilização da internet como meio de disseminação de obras musicais. Tem lugar minuciosa verificação prática dos modos de exploração do mercado fonográfico digital.

O Capítulo 3 versa sobre o conflito entre direitos autorais e direito de acesso aos bens culturais, o que se faz por meio da apresentação das perspectivas do segmento de mercado musical e seus impactos no direito autoral, mediante o estudo das novéis formas de utilização musical que se apresentam. Faz-se, também, cuidadoso estudo sobre os mecanismos tecnológicos de proteção aos direitos autorais e são verificadas as propostas existentes, que visam a conformação dos interesses em jogo.

Objetivando ampliar a reflexão sobre o tema ora versado, buscou-se suporte na literatura estrangeira, e excertos dela utilizados foram traduzidos livremente, disponibilizando-se em notas de rodapé o texto em seus idiomas originais. 


\title{
CAPÍTULO 1 \\ AS EVOLUÇÕES TECNOLÓGICAS E AS CRISES DO DIREITO AUTORAL NA MÚSICA
}

\author{
1.1 A MÚSICA NA LEI N. ${ }^{\circ} 9.610 / 98$
}

\subsubsection{O Objeto da Proteção Autoral na Obra Musical}

Apresenta-se grande dificuldade em definir o significado de "música"2, de modo que para o presente estudo será adotada a definição estipulativa de que consiste numa combinação de sons e de silêncios que se desenvolvem ao longo do tempo ${ }^{3}$.

A música, mais do que apenas exprimir sentimentos do autor ou do intérprete, os faz aflorar nas mais variadas formas naqueles que a escutam. Para muitos, a música está conectada ao espiritual; para outros, à natureza, ao cultural, ao funcional, ao social. Desde o aparecimento do homem e nas várias etapas da evolução humana, a música sempre esteve

2 "Nos parece entretanto que tentar decifrar o que é a música nada mais resultaria do que no exercício de criar uma armadilha na qual aprenderíamos apenas uma parte de nossa questão. Qualquer definição de música representaria, quando muito, a definição de uma música em particular, ou ainda, apenas o ponto de visita restrito e particular sobre o assunto. A validade dessa busca por algo que não cabe dentro de definições estanques é questionável na medida em que a música se apresenta como estrutura dinâmica e viva que se reconfigura dentro de suas práticas, dentro da criação e da escuta e como tal deve ser percebida como algo vivo, em constate mutação e que se atualiza a cada momento de sua realização: 'ninguém pode dizer o que é música, a não ser por proposições normativas, porque 'música em si' é de fato algo não demonstrável e sua prática não é nem arbitrária nem baseada em fundações físicas ou metafísicas' (Vaggione, 2001: 55). Ao contrário, embora possamos falar de música com muita propriedade, esse discurso não se baseia necessariamente em dados precisos ou formalizáveis, embora possam ser objetivos e não-arbitrários." (IAZZETTA, Fernando. O que é a música (hoje). Trabalho apresentado no I FÓRUM CATARINENSE DE MUSICOTERAPIA, Florianópolis, 31 ago. e 01 set. de 2001. Disponível em: $<$ http://www.eca.usp.br/prof/iazzetta/papers/forum2001.pdf>. Acesso em: 10 dez. 2007).

3 Para Luis Ellmerich, a música é "uma criação da inteligência humana, contendo dois fatôres: o primeiro é de ordem artística porque a música é arte na manifestação do belo por meio dos sons; o segundo, é científico porque a produção e combinação dos sons são regulados por leis físicas" (ELLMERICH, Luis. História da música. 2.ed. São Paulo: Boa Leitura, 1964. p.20). Mediante tal definição pode-se perceber o motivo da dificuldade em se definir a música: seria a música apenas a manifestação do belo? O feio então não poderia ser música? Mais além: o que seria o belo e o que seria o feio? 
presente, inegavelmente fortalecida e popularizada diante do surgimento e aprimoramento de tecnologias de fixação, reprodução, difusão e comunicação ${ }^{4}$.

Pelo entendimento comum da importância da música é que o direito de autor lhe reserva especial enfoque normativo, que abrange desde o direito dos tratados até as legislações internas dos países.

Concede-se, assim, proteção ao autor musical (compositor) mediante a intervenção da disciplina do direito autoral na defesa das "as composições musicais, tenham ou não letra"5, "criações do espírito, expressas por qualquer meio ou fixadas em qualquer suporte, tangível ou intangível, conhecido ou que se invente no futuro"6. Protege-se a obra para proteger o autor.

Para Deborah De Angelis:

O objeto da tutela é, portanto, todo gênero de expressão musical que atenda aos requisitos de criatividade e originalidade exigidos pelo legislador. A obra deve assim representar o fruto da atividade criativa do autor, como expressão de seu trabalho intelectual e deve, além disso, revestir um quid novi que a distinga das obras precedentes do mesmo gênero. A atividade criativa deve concretizar-se em uma forma perceptível, ainda que não se exija que seja fixada sobre um suporte tangível. ${ }^{7}$

Manuel de Andrade delimita o instituto do direito de autor:

O objecto de tais direitos é a respectiva obra na sua forma ideal, na sua concepção intelectual, e não a coisa ou as coisas materiais que constituem a sua corporização ou encarnação exterior, através das quais ela fez a sua aparição no mundo sensível. Os direitos que recaem sobre essas coisas materiais são vulgares direitos de propriedade, salva qualquer variante não essencial. Os que recaem sobre a obra como entidade ideal, como particular combinação de pensamentos ou impressões, é que revestem uma fisionomia específica, embora muito próxima, nos seus principais aspectos, da dos direitos reais sobre coisas corpóreas. A obra ideal constitui, pois, um quid

4 Cf. Deborah De Angelis. Informa também a autora italiana que o histórico da música foi perdido no tempo, em vista da ausência ou da simplicidade rudimentar dos meios primitivos de transposição da obra musical em um corpus mechanicum (De ANGELIS, Deborah. La tutela giuridica delle opere musicali digitali. Milão: Giuffrè, 2005. p.80-81).

5 Lei.$^{\circ}$ 9.610/98 (LDA), art. 7, V.

6 LDA, art. 7, caput.

7 Tradução livre de "oggetto della tutela è, pertanto, ogni genere di espressione musicale che risponda ai requisiti di creatività ed originalità richiesti dal legislatore. L'opera deve cioè rappresentare il frutto dell'attività creative dell'autore, come espressione del suo lavoro intellettuale e deve, inoltre, rivestire un quid novi che la distingua dalle opere precedenti dello stesso genere. L'attività creativa deve concretizzarsi in una forma percepibile, anche se non è richiesto che essa sia fissata su di un supporto tangibile" (De ANGELIS, La tutela giuridica..., p.109). A autora faz tal assertiva a respeito do objeto da proteção na lei autoral italiana (Legge 633/1941). 
independente das suas incarnações materiais. É um bem que a ordem jurídica provê da tutela que julgou adequada, mediante a concessão daqueles direitos. Estes resumem-se no poder de disposição exclusiva da mesma obra, facultado ao seu autor dentro de certos limites, só a ele competindo autorizar que a obra seja tornada pública (deixe de ser inédita) ou por qualquer modo seja reproduzida, executada (composição dramática), traduzida (obra literária ou científica), adaptada ou corrigida. Tal poder de disposição exclusiva manifesta-se, principalmente, através de prerrogativas que tendem a reservar para o autor a exploração econômica da obra. Mas comporta ainda certas outras prerrogativas (faculdade de deixa inédita a obra. De impedir a sua publicação em nome de autor ou sob um falso nome. De obstar a que, uma vez publicada, seja ulteriormente reproduzida com modificações), inspiradas na ideia de salvaguardar a personalidade do autor enquanto reflectida na obra cuja paternidade intelectual lhe pertence. $^{8}$

Ao exteriorizar seus sentimentos, o ser humano compartilha-os com a coletividade por meio da expressão ou materialização de suas criações de espírito, o que é feito no exercício das garantias constitucionais de liberdade de expressão ${ }^{9}$, de criação ${ }^{10} \mathrm{e}$ de proteção ao direito de autor ${ }^{11,12}$. Extrai, assim, do substrato comum elementos que, transformados pelo seu intelecto, mediante a criatividade13, são devolvidos por meio da obra musical como o "plus que se acresce ao acervo comum"14.

8 ANDRADE, Manuel. Teoria geral da relação jurídica, I. Coimbra: polic. [segundo a edição da Livraria

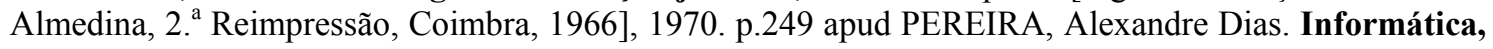
direito de autor e propriedade tecnodigital. Coimbra: Coimbra Editora, 2001. p.140.

9 Constituição Federal, art. 5. ${ }^{\circ}$, IX: "é livre a expressão da atividade intelectual, artística, científica e de comunicação, independentemente de censura ou licença".

10 Constituição Federal, art. 220: "A manifestação do pensamento, a criação, a expressão e a informação, sob qualquer forma, processo ou veículo não sofrerão qualquer restrição, observado o disposto nesta Constituição. § $2{ }^{\circ}$ - É vedada toda e qualquer censura de natureza política, ideológica e artística".

11 Constituição Federal, art. 5. ${ }^{\circ}$, XXVII: "aos autores pertence o direito exclusivo de utilização, publicação ou reprodução de suas obras, transmissível aos herdeiros pelo tempo que a lei fixar"; e XXVIII "são assegurados, nos termos da lei: a) a proteção às participações individuais em obras coletivas e à reprodução da imagem e voz humanas, inclusive nas atividades desportivas; b) o direito de fiscalização do aproveitamento econômico das obras que criarem ou de que participarem aos criadores, aos intérpretes e às respectivas representações sindicais e associativas".

12 Pontes de Miranda aponta a intrínseca relação entre liberdade de criação e direitos autorais: "É exercendo a liberdade de criar, de produzir obras, inseparável do homem, que êles os adquirem. A liberdade de criar é direito a criar obras." (PONTES DE MIRANDA, Francisco Cavalcanti. Tratado de direito privado. Rio de Janeiro: Borsoi, 1956. Tomo VII. p.143).

13 Para Antônio Chaves, "A matéria-prima do direito de autor é, com efeito, mais preciosa do que os materiais e metais mais raros: a criatividade, extraordinário e misterioso atributo de que a natureza privilegiou o homem." (CHAVES, Antônio. Criador da obra intelectual. São Paulo: LTr, 1995. p.29).

14 Para Carlos Alberto Bittar, "a criatividade é, pois, elemento ínsito nessa qualificação: a obra deve resultar de esforço intelectual, ou seja, de atividade criadora do autor, com a qual introduz na realidade fática manifestação intelectual estética não existente (o plus que se acresce ao acervo comum)" (BITTAR, Carlos Alberto. Curso de direito autoral. Rio de Janeiro: Forense, 1988. p.24). 
Note-se, entretanto, que na concepção moderna do direito autoral continua-se ressaltando o aspecto fundamental da criação humana ${ }^{15}$, mas sua defesa não se dá mais pela justificativa do direito natural, mas sim pela proteção ao criador mediante a concessão de direitos específicos e proteção à sua obra, para que contribua com o interesse público da coletividade em ter acesso às obras musicais ${ }^{16}$.

A definição de obra ${ }^{17}$, para Pierre-Yves Gautier, é "todo esforço de inovação do espírito humano, condutor a uma produção intelectual, que pode ter um objetivo prático, mas deve comportar um mínimo de efeito estético, atrelada de qualquer maneira às belas artes".

A originalidade ${ }^{18}$ é ínsita à criação musical, sendo certo que não se pode exigi-la na forma absoluta, sob pena de criar-se uma indevida reserva de mercado sobre o patrimônio

15 "Com efeito, traduzindo-se a originalidade na impressão digital do criador que individualiza a obra, interesses ligados à sua pessoa reclamam também protecção, uma vez que aquela é criação desta. Para ser protegida, a obra deve ter a sua origem no exercício da liberdade de criação que se reconhece às pessoas humanas." (PEREIRA, Informática, direito..., p.249).

16 Para Eduardo Vieira Manso "o moderno Direito Autoral afasta-se, cada vez mais, das concepções individualistas que o estruturaram em suas origens, principalmente por influência da Revolução Francesa, passando a estender seu amparo muito mais à própria obra intelectual do que ao seu autor" e "o interesse público que há sobre e por toda obra intelectual é que fundamenta a extensão das prerrogativas próprias de seu autor, a quem são atribuídos direitos que lhe possibilitam, a um só tempo, extrair desse bem todo proveito econômico a que possa dar causa, e zelar por sua inteireza e pela manutenção de suas peculiaridades, a fim de resguardar o seu valor intelectual, e, pois, preservar o bem cultural (bom ou mal, é indiferente), conforme a pessoal concepção do próprio autor. Essa preservação visa a manter a obra, tanto quanto possível, naquela genuína forma como resultou da atuação da sociedade sobre o espírito do autor, levando este àquela precisa manifestação intelectual" (MANSO, Eduardo Vieira. Direito autoral: exceções impostas aos direitos autorais: derrogações e limitações. São Paulo: Bushatski, 1980. p.23-24). Note-se, entretanto, que tal retribuição garantida ao autor não deve ser considerada como uma retribuição por trabalho, conforme explica Vittorio M. de Sanctis: "D'altra parte, è pacifico che il diritto di autore non possa essere considerato né la retribuzione di un lavoro, perché ciò implicherebbe un giudizio sulla qualità e quantità dello sforzo lavorativo impiegato nell'opera, né la retribuzione per un contributo dell'autore all'arte o alla cultura, perché anche ciò implicherebbe un giudizio di valore estetico che è invece estraneo alla tutela dell'autore, cosi come modernamente concepita." (SANCTIS, Vittorio M. de. I soggetti del diritto d'autore. Milão: Giuffrè, 2000. p.21).

17 Tradução livre de "Nous proposons, en l'état du droit positif, de définir 'œuvre' tout effort d'innovation de l'esprit humain, condusiant à une production intellectuelle, qui peut tendre vers un but pratique, mais doit comporter un minimum d'effet esthétique, la rattachant d'une quelconque façon à l'ordre des BeauxArts." (GAUTIER, Pierre-Yves. Propriété littéraire et artistique. 2e éd. mise à jour. Paris: Presses Universitaires de France, 1996. p.60).

18 Alertava Pedro Bobbio que "originalidade é conceito que só pode ser aceite na tecnica jurídica por definição negativa, sob pena de arbitrariedade. Não podemos definir o que seja. Apenas poderemos considerar original o que não possa ser confundido com outra creação intelectual, por excesso de semelhança, substancial ou formal. Assim consideraremos objeto de direito de autor toda obra literaria, artistica ou cientifica que, constituindo projeção externa da personalidade de seu creador, não seja apenas imitação pedissequa de creação inteletual preexistente e possua carateristicos individuais eliminadores de qualquer possibilidade de confusão com outras obras do mesmo gênero" (BOBBIO, Pedro Vicente. O direito de autor na creação musical. São Paulo: LEX, 1951. p.14). 
cultural comum ${ }^{19}$ e de impedir o desenvolvimento de novos estilos musicais. É por isso que não se exige a novidade, a exemplo do que ocorre no âmbito da propriedade industrial, notadamente no caso das patentes de invenção.

Nessa relativa originalidade, para a obra ser considerada criação primígena, devem estar presentes características próprias passíveis a individualizá-la, sendo aceitável que sejam oriundas dos patrimônio cultural comum, mas não que sejam derivadas de outras obras intelectuais protegidas. Se o forem, hão de ser autorizadas pelo criador originário e serão consideradas "obras derivadas" 20 , a essas sendo conferida a mesma proteção daquela originária, já que, para fins legais, também é considerada original21.

Assim, é objeto de proteção autoral a composição musical, tenha letra ou não, sendo que constituirá obra, "para efeitos de protecção pelo direito de autor, na medida em que constitua uma forma original de expressão comunicativa literária ou artística com sentido individual próprio, ainda que de carácter utilitário ou funcional"22.

19 Para Mario Are, "anche per le opere musicali, tuttavia, non si può ipotizzare una assoluta originalità, poiché esse, come tutte le altre opere dell'ingegno, si fondano necessariamente sull'intelletto oggettivato ed in particolare sul patrimonio culturale comune" (ARE, Mario. L'oggetto del diritto di autore. Milão: Giuffrè, 1963. p.369). No mesmo sentido, Carlos Alberto Bittar: "ademais, presenta a originalidade caráter relativo, não se exigindo, pois, novidade absoluta, eis que inexorável é, de um ou outro mundo, o aproveitamento, até inconsciente, do acervo cultural comum" (BITTAR, Curso de direito autoral, p.25).

20 LDA, art. 5, VIII, g: "Art. 5. ${ }^{\circ}$ Para os efeitos desta Lei, considera-se: VIII - obra, g) derivada - a que, constituindo criação intelectual nova, resulta da transformação de obra originária".

21 Perceba-se a diferenciação, para fins de direito de autor, em relação ao significado de "obra originária" e "obra original". Originária é aquela obra dotada de originalidade suficiente para ser considerada protegida pelo direito de autor e, portanto primígena, de acordo com o artigo 5. ${ }^{\circ}$, VIII, f da LDA. Entretanto, mesmo a obra derivada, se devidamente autorizada pelo criador da obra originária e dotada de suficiente originalidade, será considerada original para fins de proteção pelo direito de autor, com a mesma proteção que a obra originária. Para Delia Lipszyc: "en el derecho de autor, el término creación no tiene el significado corriente de sacar algo de la nada y la originalidad de la obra no tiene de ser absoluta. No es necesario que la inspiración del autor esté libre de toda influencia ajena. Las ideas utilizadas en la obra pueden ser viejas y, sin embargo, la obra puede ser original pues, insistimos, el derecho de autor admite que la creación intelectual se realice sobre la base de elementos prévios. Solo es necesario que la obra sea distinta de las que existían con anterioridad, que no se a una copia o imitación de otra" (LIPSZYC, Delia. Derecho de autor y derechos conexos. Paris: UNESCO, 2001. p.66).

22 PEREIRA, Informática, direito..., p.253. 


\title{
Na lição de André Bertrand
}

\begin{abstract}
A criação musical pode resultar da composição de uma nova obra original ou do arranjo de uma composição pré-existente. Ela pode igualmente, como as outras criações, resultar seja de uma concepção refletida de seu autor, seja de improvisações, fazendo o objeto de uma fixação. No que concerne às letras das canções, podem ser consideradas como originais todas as justaposições de frases arbitrárias, mesmo banais. ${ }^{23}$
\end{abstract}

Com efeito, protege-se, assim, a obra musical, caracterizada pelas composições musicais, com letra ou não ${ }^{24}$, sendo relevante notar, desde já, que se trata de objeto diferente do fonograma, que consiste na fixação de sons $^{25}$, cuja autorização depende do compositor, entretanto, uma vez efetuada, corresponde a um direito conexo do produtor musical, conforme será visto adiante.

\subsubsection{Os Sujeitos de Direitos Autorais na Música}

A lei autoral assegura direito de autor à pessoa física ${ }^{26}$ criadora de obra literária, artística ou científica $^{27}$, independente de registro ${ }^{28}$, sendo considerado autor aquele que indicar ou anunciar essa qualidade na utilização da obra, não havendo prova em contrário ${ }^{29}$.

23 BERTRAND, André. La musique et le droit De Bach à Internet. Paris: Éditions Litec, 2002. p.36. Para o autor, "A estrutura musical ocidental se caracteriza tradicionalmente por três elementos: a melodia, a harmonia e o ritmo, cuja reprodução isolada ou combinada pode constituir, conforme a jurisprudência, um ato de contrafação. De uma maneira geral, a música ocidental "é concebida em uma estrutura complexa na qual irá se instaurar uma dialética entre a melodia, a harmonia e o ritmo que a compõe, e que pode conduzir à aparição de um ou dois dominantes. Dito de outra forma, em uma estrutura concebida, irá se estabelecer uma relação entre essencial e acessório (...). Em resultado os três elementos da obra musical podem respectivamente tornar-se o dominante desta estrutura". Portanto, essa análise tradicional representa pouco ou nenhum interesse no que diz respeito a certas músicas de origem e/ou de inspiração folclórica ou não ocidental, bem como de outro lado, certas músicas criadas por sistemas de informática", (p.47) - tradução livre.

24 LDA, "art. 7, V - as composições musicais, tenham ou não letra";

25 LDA, "art. 5, IX - toda fixação de sons de uma execução ou interpretação ou de outros sons, ou de uma representação de sons que não seja uma fixação incluída em uma obra audiovisual".

26 "Com efeito, traduzindo-se a originalidade na impressão digital do criador que individualiza a obra, interesses ligados à sua pessoa reclamam também protecção, uma vez que aquela é criação desta. Para ser protegida, a obra deve ter a sua origem no exercício da liberdade de criação que se reconhece às pessoas humanas". (PEREIRA, Informática, direito..., p.249). "Las personas físicas son las únicas que tienen aptitud para realizar actos de creación intelectual". (LIPSZYC, Derecho de autor..., p.123).

27 LDA, art. 11. O parágrafo único deste artigo prevê a extensão da proteção ao autor às pessoas jurídicas, nos casos previstos na mesma lei. Note-se que o que se faz é a extensão da proteção e não a atribuição da autoria.

28 LDA, "Art. 18. A proteção aos direitos de que trata esta Lei independe de registro". 
No caso da obra musical, o autor é o compositor, sujeito originário do direito de autor ou, no caso de haver mais de um autor, tanto compositores quanto letristas, institui-se a co-autoria ${ }^{30}$, que legitima todos os co-autores ao exercício, em comum acordo, dos direitos morais e patrimoniais de autor ${ }^{31}$.

A proteção pelo direito de autor se inicia no exato momento da criação da obra protegida $^{32}$ e perdura, no aspecto patrimonial, pelo prazo de setenta anos após a morte do autor ${ }^{33}$.

São também sujeitos de direitos autorais na música, por meio dos direitos conexos aos de autor: o produtor musical ${ }^{34}$, as empresas de radiodifusão e os artistas intérpretes ou executantes ${ }^{35}$, sobre os quais será tratado no presente estudo.

29 LDA, "Art. 12. Para se identificar como autor, poderá o criador da obra literária, artística ou científica usar de seu nome civil, completo ou abreviado até por suas iniciais, de pseudônimo ou qualquer outro sinal convencional. Art. 13. Considera-se autor da obra intelectual, não havendo prova em contrário, aquele que, por uma das modalidades de identificação referidas no artigo anterior, tiver, em conformidade com o uso, indicada ou anunciada essa qualidade na sua utilização".

30 LDA, "Art. 15. A co-autoria da obra é atribuída àqueles em cujo nome, pseudônimo ou sinal convencional for utilizada." É muito comum que na criação musical mais de uma pessoa se envolva, já que o compositor pode criar a melodia, a seqüência de sons, enquanto outro autor cria a letra da música, na chamada "obra em colaboração", que para Delia Lipszyc "son las creadas por dos o más personas que trabajan juntas, o al menos tienen mutuamente em cuenta sus contribuciones, y bajo uma inspiración común" (LIPSZYC, Derecho de autor..., p.123). O legislador protegeu os criadores intelectuais na medida em que incluiu o seguinte parágrafo "§ $1 .^{\circ}$ Não se considera co-autor quem simplesmente auxiliou o autor na produção da obra literária, artística ou científica, revendo-a, atualizando-a, bem como fiscalizando ou dirigindo sua edição ou apresentação por qualquer meio." Ainda, possibilita, no campo musical, a utilização em separado, pelo compositor ou pelo letrista, de suas contribuições na obra, desde que não cause prejuízo à exploração da obra comum. É o que diz o parágrafo segundo: "§ 2 . $^{\circ}$ Ao co-autor, cuja contribuição possa ser utilizada separadamente, são asseguradas todas as faculdades inerentes à sua criação como obra individual, vedada, porém, a utilização que possa acarretar prejuízo à exploração da obra comum." Desse modo, por exemplo, o letrista está autorizado a apresentar sua criação inclusa em um livro, se assim desejar.

31 LDA, art. 23: "Os co-autores da obra intelectual exercerão, de comum acordo, os seus direitos, salvo convenção em contrário."

32 LDA, art. 7, V. Para Vittorio de Sanctis, "ciò significa che il diritto d'autore non è attribuito al suo titolare a seguito di un atto o di un negozio di natura privatistica o pubblicistica, ma da un fatto che il soggetto pone in essere e che, sussistendone i requisiti, la legge assume come fattispecie costitutiva del diritto" (SANCTIS, I soggetti..., p.17).

33 LDA, art 41: "Os direitos patrimoniais do autor perduram por setenta anos contados de $1 .^{\circ}$ de janeiro do ano subseqüente ao de seu falecimento, obedecida a ordem sucessória da lei civil".

34 LDA, art. 5. ${ }^{\circ}$ : " XI - produtor - a pessoa física ou jurídica que toma a iniciativa e tem a responsabilidade econômica da primeira fixação do fonograma ou da obra audiovisual, qualquer que seja a natureza do suporte utilizado."

35 LDA, art. 5. . : XIII - artistas intérpretes ou executantes - todos os atores, cantores, músicos, bailarinos ou outras pessoas que representem um papel, cantem, recitem, declamem, interpretem ou executem em qualquer forma obras literárias ou artísticas ou expressões do folclore." 
Recentemente - e em decorrência da evolução tecnológica, como adiante será visto - mais um sujeito foi acrescentado aos direitos autorais: o usuário. Em vista não somente da interatividade possibilitada pelas novas tecnologias, mas principalmente da garantia constitucional e do direito dos tratados que lhe garante o acesso aos bens culturais.

\subsubsection{O Conteúdo Dúplice do Direito de Autor}

Aos autores é atribuída a titularidade dos direitos morais e patrimoniais sobre a obra criada ${ }^{36}$, em adoção à teoria dualista ${ }^{37}$. Na lição de Fabio Maria de-Mattia "o direito de autor é composto por duas realidades jurídicas independentes, por dois direitos distintos, sendo que cada um obedece às regras especiais que dirigem sua própria natureza: o direito moral e o direito pecuniário"38.

O sistema protetor do direito autoral adotado no Brasil acompanha o sistema introduzido e válido na França, no modelo chamado de direito de autor "continental" ou "latino-germânico", e apresenta fundamento jusnaturalista ${ }^{39}$, privilegiando o autor e sua

36 LDA. "Art. 22. Pertencem ao autor os direitos morais e patrimoniais sobre a obra que criou."

37 Em contraposição à teoria monista, em que seus partidários "consideran que todas las prerrogativas que corresponden al creador tanto de carácter personal como patrimonial constituyen manifestaciones de un derecho unitario que garantiza, en su conjunto, tanto los intereses intelectuales del autor como los económicos" (LIPSZYC, Derecho de autor..., p.152).

38 DE MATTIA, Fabio Maria. O direito de tradução no direito comparado. In: DE MATTIA, Fabio Maria. Estudos de direito de autor. São Paulo: Saraiva, 1975. p.4. O direito moral é, nas palavras de Deborah De Angelis "la proiezione dello stretto legame che sussiste tra l'autore e la sua opera, ove si fondono la qualità più intime dell'artista (inteso come autore)", enquanto que o direito patrimonial é, nas palavras da mesma autora, que analisava o caso da obra musical "il potere di sfruttare economicamente l'opera musicale, creando così una sorta di monopolio legale intorno all'oggeto della tutela" (De ANGELIS, La tutela giuridica..., p.114). "El derecho patrimonial asegura al autor la exclusividad de la explotación de la obra en cualquier forma en que ésta sea utilizada, y los derechos morales o extrapatrimoniales se traducen en una serie de prerrogativas personales derivadas del hecho de la creación." (EMERY, Miguel Ángel. Propriedad Intelectual. Buenos Aires: Editorial Astrea, 2003. p.76). Na LDA, o conteúdo e regras do direito moral (os 'direitos morais') estão dispostos no Capítulo II, artigos 24 a 27 , enquanto que o conteúdo e regras do direito patrimonial ('direitos patrimoniais') estão no Capítulo III, artigos 28 a 45 .

39 É o que sintetizava o célebre dito de Le Chapelier: "la plus sacrée, la plus personelle de toutes les proprietés est l'ouvrage fruit de la pensée d'un écrivain" apud UBERTAZZI, Luigi Carlo. I diritti d'autore e connessi. 2.ed. Milão: Giuffrè Editore, 2003. p.9. No mesmo sentido, Pedro Vicente Bobbio: "os direitos interentes à creação da obra são, por natureza, pessoais perpetuos, inalienaveis". (BOBBIO, O direito de autor..., p.7) e Antonio Chaves, para quem "se algum direito natural existe, nenhum poderá ser mais 'natural' do que o direito de autor" (CHAVES, Antônio. Direito do autor: princípios fundamentais. Rio de Janeiro: Forense, 1987. p.4). É perceptível, entretanto, a mudança do entendimento doutrinário, porquanto boa parte da nova geração de autoralistas entende que a justificativa jusnaturalista não se 
indissociável relação com sua obra, no reconhecimento primaz do caráter moral do direito de autor, muito embora também contemple o aspecto patrimonial. Entretanto, a evolução do direito autoral alterou a justificativa, passando a focar a proteção ao criador mediante a concessão de direitos específicos e proteção à sua obra, para que este contribua com o interesse público da coletividade em ter acesso às obras musicais.

A Constituição Federal de 1988 garante aos autores, no título dos direitos e garantias individuais, o direito exclusivo à utilização, publicação ou reprodução de suas obras ${ }^{40}$, assim como lhes assegura o direito de fiscalização do respectivo aproveitamento econômico de suas criações, extensivo aos intérpretes em relação às suas participações ${ }^{41}$.

Foi preocupação do legislador constituinte garantir o caráter patrimonial dos direitos autorais, já que os direitos elencados são de tal natureza, salvo a publicação, que possui caráter dúplice, pelo aspecto moral que contém ${ }^{42}$. Ambos os dispositivos constitucionais conferem à lei o caráter regulamentar, motivo pelo qual constituem substrato direto ao Capítulo III da Lei n. ${ }^{\circ}$ 9.610/9843.

sustenta: "Non si può tuttavia sottovalutare nemmeno la valenza ideologica del riferimento iniziali agli strumenti proprietari di tutela giuridica: perché questo riferimento esprimeva una determinata concezione borghese e liberale, che assegnava al diritto di proprietà un ruolo centrale ed un fondamento giusnaturalistico; e perché il medesimo riferimento perde progressivamente colore col declino dell'ideologia liberale." (UBERTAZZI, I diritti d'autore..., p.56); "Pois que a criação da Propriedade Intelectual é - completa e exclusivamente - uma elaboração da lei, que não resulta de qualquer direito imanente, anterior a tal legislação." (BARBOSA, Denis Borges. Uma introdução à propriedade intelectual. Rio de Janeiro: Lúmen Júris, 2003. p.88); "Esse direito também não pode ser atribuído ao autor por lhe ser 'natural', pois se trata de um direito histórico-cultural como qualquer outro." (CARBONI, Guilherme. Função social do direito de autor. Curitiba: Juruá, 2006. p.18); e, em crítica ao que denomina "sistema tradicional de direitos autorais", cf; STAUT JÚNIOR, Sérgio Said. Percurso e crise dos direitos autorais: uma leitura crítica da expressão patrimonial e do conteúdo moral. 2002. Dissertação (Mestrado em Direito) - Setor de Ciências Jurídicas - Universidade Federal do Paraná, Curitiba, 2002. p.55 e segs.

40 Constituição Federal, "art. 5. ${ }^{\circ}$, XXVII - aos autores pertence o direito exclusivo de utilização, publicação ou reprodução de suas obras, transmissível aos herdeiros pelo tempo que a lei fixar."

41 Constituição Federal, "art. 5. ${ }^{\circ}$, XXVIII - são assegurados, nos termos da lei: b) o direito de fiscalização do aproveitamento econômico das obras que criarem ou de que participarem aos criadores, aos intérpretes e às respectivas representações sindicais e associativas".

42 LDA: "Art. 24. São direitos morais do autor: III - o de conservar a obra inédita".

43 LDA: "Capítulo III. Dos Direitos Patrimoniais do Autor e de sua Duração.

Art. 28. Cabe ao autor o direito exclusivo de utilizar, fruir e dispor da obra literária, artística ou científica. Art. 29. Depende de autorização prévia e expressa do autor a utilização da obra, por quaisquer modalidades, tais como:

I - a reprodução parcial ou integral;

II - a edição;

III - a adaptação, o arranjo musical e quaisquer outras transformações; 
De outro modo, percebe-se a ausência de menção expressa da proteção constitucional aos direitos morais, com o que se poderia partir do pressuposto de que a previsão contida na LDA, especificamente aquela do artigo 24, exorbita o mandamento constitucional e, portanto, ultrapassaria o clássico entendimento da prevalência dos direitos morais em relação aos patrimoniais, que constitui fundamento do direito de autor latino-germânico, ou mesmo em relação ao seu conteúdo dúplice.

É um tema relevante, causador de discussões doutrinárias. Para Denis Borges Barbosa, "provavelmente haveria alguma razão para listar entre os direitos fundamentais o estrato moral dos direitos autorais e de propriedade industrial"44. Na opinião de Guilherme Carboni:

O legislador constituinte falhou ao não fazer referência expressa ao direito de paternidade (que, conforme já mencionado, é o direito moral de autor por excelência) no rol dos direitos e garantias fundamentais no art. 5. ${ }^{\circ}$ da Carta Magna, pois é ele

IV - a tradução para qualquer idioma;

V - a inclusão em fonograma ou produção audiovisual;

VI - a distribuição, quando não intrínseca ao contrato firmado pelo autor com terceiros para uso ou exploração da obra;

VII - a distribuição para oferta de obras ou produções mediante cabo, fibra ótica, satélite, ondas ou qualquer outro sistema que permita ao usuário realizar a seleção da obra ou produção para percebê-la em um tempo e lugar previamente determinados por quem formula a demanda, e nos casos em que o acesso às obras ou produções se faça por qualquer sistema que importe em pagamento pelo usuário;

VIII - a utilização, direta ou indireta, da obra literária, artística ou científica, mediante:

a) representação, recitação ou declamação;

b) execução musical;

c) emprego de alto-falante ou de sistemas análogos;

d) radiodifusão sonora ou televisiva;

e) captação de transmissão de radiodifusão em locais de freqüência coletiva;

f) sonorização ambiental;

g) a exibição audiovisual, cinematográfica ou por processo assemelhado;

h) emprego de satélites artificiais;

i) emprego de sistemas óticos, fios telefônicos ou não, cabos de qualquer tipo e meios de comunicação similares que venham a ser adotados;

j) exposição de obras de artes plásticas e figurativas;

IX - a inclusão em base de dados, o armazenamento em computador, a microfilmagem e as demais formas de arquivamento do gênero;

$\mathrm{X}$ - quaisquer outras modalidades de utilização existentes ou que venham a ser inventadas.

Art. 30. No exercício do direito de reprodução, o titular dos direitos autorais poderá colocar à disposição do público a obra, na forma, local e pelo tempo que desejar, a título oneroso ou gratuito.

$\S 1 .^{\circ} \mathrm{O}$ direito de exclusividade de reprodução não será aplicável quando ela for temporária e apenas tiver o propósito de tornar a obra, fonograma ou interpretação perceptível em meio eletrônico ou quando for de natureza transitória e incidental, desde que ocorra no curso do uso devidamente autorizado da obra, pelo titular.

$\S 2 .^{\circ}$ Em qualquer modalidade de reprodução, a quantidade de exemplares será informada e controlada, cabendo a quem reproduzir a obra a responsabilidade de manter os registros que permitam, ao autor, a fiscalização do aproveitamento econômico da exploração.

Art. 31. As diversas modalidades de utilização de obras literárias, artísticas ou científicas ou de fonogramas são independentes entre si, e a autorização concedida pelo autor, ou pelo produtor, respectivamente, não se estende a quaisquer das demais".

44 BARBOSA, Uma introdução..., p.92. 
que mereceria a classificação como direito fundamental e não os direitos de propriedade industrial ou o direito patrimonial de autor que, a nosso ver, são reflexos de movimentos de política econômica e cultural. ${ }^{45}$

Realmente, o constituinte deixou passar uma boa oportunidade para incluir na Constituição Federal de 1988 a proteção ao direito moral de autor, em termos expressos e inequívocos.

Por outro lado, o Brasil é signatário de tratados, a exemplo da Declaração Universal dos Direitos Humanos ${ }^{46}$ e da Convenção de Berna ${ }^{47}$, que referenciam expressamente a proteção ao direito moral de autor ${ }^{48}$, de sorte que a proteção conferida pela Lei n. ${ }^{\circ}$ 9.610/98 ao direito moral de autor é indiretamente justificada pela Constituição Federal (por meio da garantia de liberdade de expressão e do princípio da dignidade da pessoa humana) e diretamente justificada pelos tratados aqui devidamente internalizados.

Os direitos morais de autor ${ }^{49}$ estão incluídos no rol dos "direitos da personalidade", muito embora - ressalva Bruno Jorge Hammes ${ }^{50}$ - não possam ser confundidos com o direito de personalidade em geral.

45 CARBONI, Função social..., p.145.

46 "Artigo XXVII. 2. Toda pessoa tem direito à proteção dos interesses morais e materiais decorrentes de qualquer produção científica, literária ou artística da qual seja autor".

47 "Artigo 6-bis. 1. Independentemente dos direitos patrimoniais do autor, e mesmo após a cessão desses direitos, o autor conserva o direito de reivindicar a paternidade da obra e de se opor a qualquer deformação, mutilação ou outra modificação dessa obra ou a qualquer atentado a mesma obra, que possam prejudicar a sua honra ou a sua reputação".

48 Já o TRIPS - Acordo sobre aspectos dos direitos de propriedade intelectual relacionados ao comércio -, firmado como passo para a harmonização entre o direito de autor latino-germânico e o copyright, não prevê a obrigatoriedade da observância dos direitos morais, por seus membros que não signatários da Convenção de Berna: "ARTIGO 9. Relação com a Convenção de Berna. 1 - Os Membros cumprirão o disposto nos Artigos 1 a 21 e no Apêndice da Convenção de Berna (1971). Não obstante, os Membros não terão direitos nem obrigações, neste Acordo, com relação aos direitos conferidos pelo art.6 'bis' da citada Convenção, ou com relação aos direitos dela derivados". O Brasil é signatário desse tratado, que embasou a vigente Lei autoral.

49 "O princípio da pessoalidade do conteúdo do direito de autor significa, nos termos da lei, que este abrange, para além de direitos patrimoniais, direitos de natureza pessoal, denominados direitos morais (art. 9. $\left..^{\circ}, 1\right)$. Trata-se, designadamente, do direito de reivindicar a respectiva paternidade de assegurar a sua genuidade, independentemente dos direitos patrimoniais, e mesmo depois da transmissão ou extinção destes (art. 9. ${ }^{\circ}, 3$ ). Sendo que, autor é o criador intelectual da obra, ou seja, a pessoa humana à qual se deve a origem da forma original de expressão comunicativa. $\mathrm{Na}$ verdade, para que a obra goze de protecção é necessário que seja original, isto é, que tenha a 'impressão digital' do seu criador. Nessa medida, sendo a obra expressão da personalidade do criador, o direito de autor tutela-a por via do reconhecimento de direitos morais ao autor, protegendo o laço pessoal entre a obra e o seu criador.". (PEREIRA, Informática, direito..., p.359-360). 
Para Carlos Alberto Villalba e Delia Lipszyc ${ }^{51}$ :

o direito moral é um direito da personalidade do autor em relação com a existência, a circulação e a exploração de uma obra determinada; diferentemente do que acontece com os direitos da personalidade em geral, também denominados direitos personalíssimos, o direito moral de autor não é inato: não o tem todas as pessoas, pelo simples fato de serem tais, senão aquele que cria uma obra e em relação a esta.

Conforme o artigo 24 da $\mathrm{LDA}^{52}$, são direitos morais: o reconhecimento à paternidade; a indicação do nome por ocasião da utilização; o direito de inédito; à integridade da obra; e o de modificação, sendo que o primeiro, o da paternidade, pode ser considerado o mais importante de todos ${ }^{53}$.

Na música, muito embora se constatem com freqüência infrações aos direitos morais, principalmente em relação à nominação no momento da utilização e falsa atribuição de autoria, o que realmente apresenta desafio é a exploração dos direitos patrimoniais conferidos

50 HAMMES, Bruno Jorge. O direito de propriedade intelectual: subsídios para o ensino. 3.ed. São Leopoldo: Ed. Unisinos, 2002. p.60. O autor ainda menciona o exemplo anedótico do Prof. Eugen Ulmer: "contam ao pintor $\mathrm{P}$ que um colega medíocre (M) estaria afirmando que uma porção de quadros de $\mathrm{P}$, em verdade, teriam sido pintados por ele (M). P teria respondido: 'Enquanto $\mathrm{M}$ anuncia que ele teria pintado os meus quadros, prefiro silenciar; se, entretanto, dissesse que eu pintara os seus quadros, protestaria'. No primeiro caso haveria uma violação de direito moral de autor, no segundo uma violação de direito de personalidade em geral. O direito moral seria a ligação (vínculo) do direito de autor em seu todo a uma determinada obra.

51 VILLALBA, Carlos Alberto; LIPSZYC, Delia. El derecho de autor en la Argentina. Buenos Aires: La Ley, 2001. p.83.

52 LDA, "Art. 24. São direitos morais do autor: I - o de reivindicar, a qualquer tempo, a autoria da obra; II - o de ter seu nome, pseudônimo ou sinal convencional indicado ou anunciado, como sendo o do autor, na utilização de sua obra; III - o de conservar a obra inédita; IV - o de assegurar a integridade da obra, opondo-se a quaisquer modificações ou à prática de atos que, de qualquer forma, possam prejudicá-la ou atingi-lo, como autor, em sua reputação ou honra; V - o de modificar a obra, antes ou depois de utilizada; VI - o de retirar de circulação a obra ou de suspender qualquer forma de utilização já autorizada, quando a circulação ou utilização implicarem afronta à sua reputação e imagem; VII - o de ter acesso a exemplar único e raro da obra, quando se encontre legitimamente em poder de outrem, para o fim de, por meio de processo fotográfico ou assemelhado, ou audiovisual, preservar sua memória, de forma que cause o menor inconveniente possível a seu detentor, que, em todo caso, será indenizado de qualquer dano ou prejuízo que lhe seja causado."

53 No mesmo sentido, Antonio Chaves: "(...) sem dúvida, o mais importante de todos, isto é, o direito ao reconhecimento da paternidade da obra" (CHAVES, Antonio. Proteção internacional do direito autoral de radiodifusão. São Paulo: Max Limonad, 1952. p.302) e também Guilherme Carboni: "a nosso ver, o núcleo essencial do direito moral de autor (...) diz respeito à atribuição da paternidade da obra. Isso porque a atribuição da paternidade da obra a uma outra pessoa que não o próprio autor, seria um desvirtuamento da própria realidade, o qual, evidentemente, não poderia ser amparado pelo Direito". (CARBONI, Função social..., p.67). 
ao autor, pelo direito exclusivo de utilizar, fruir e dispor da obra literária, artística ou científica (art. $28 \mathrm{LDA})^{54}$.

Já dizia Pedro Bobbio ${ }^{55}$ que "de todas as creações inteletuais, a musical é que da lugar ao maior numero de especificações do direito autoral, no campo dos direitos de reprodução, ou explorativos ou patrimoniais". Com efeito, as disposições contidas no artigo 29 da LDA, seus incisos e alíneas, que versam sobre as formas de utilização da obra, podem ser todas aplicadas em função da música, diferentemente do que em relação a outras formas de obras literárias, artísticas ou científicas.

Ainda, é amplo o feixe de direitos patrimoniais assegurados, não somente ao autor ou ao cessionário titular como também aos titulares de direitos conexos (produtores musicais, intérpretes e empresas de radiodifusão) $)^{56}$, sendo certa, entretanto, a hierarquia inferior de tais direitos em relação aos dos autores ${ }^{57}$.

São inúmeras as questões jurídicas que se apresentam a partir do momento em que se envolve o caráter econômico. Conforme será visto no próximo capítulo, o que atualmente aflige os titulares de direitos autorais é o fato de que estão sendo solenemente ignorados os preceitos legais que regem o setor e não se vislumbra, ao menos em curto prazo, a perspectiva de mudança no cenário.

\subsubsection{As Exceções aos Direitos Autorais}

O compositor retira do substrato comum elementos que, modificados sob sua particular ótica e submetidos ao processo criativo, resultam na obra musical. O direito autoral, então,

54 Para Alexandre Dias Pereira, "o princípio da patrimonialidade significa que o direito de autor é composto por direitos de carácter patrimonial, abreviadamente denominados direitos patrimoniais. Vale isto por dizer que a obra é protegida enquanto fonte de aproveitamento econômico, sendo reservado ao autor o exclusivo da sua utilização e exploração. Trata-se de um bem imaterial que constitui objecto de direitos de natureza patrimonial. Com efeito, o direito de autor consiste, na sua vertente patrimonial, no direito exclusivo de dispor, fruir e utilizar a obra ou de autorizar a sua fruição e utilização, total ou parcial, por terceiro (art. 9. ${ }^{\circ}, 2$ ). Assim, a obra é um bem imaterial coisificado, integrando a categoria das coisas incorpóreas". (PEREIRA, Informática, direito..., p.303).

55 BOBBIO, $\mathrm{O}$ direito de autor..., p. 16.

56 Cf. arts. 89-96 LDA.

57 LDA, "Art. 89. As normas relativas aos direitos de autor aplicam-se, no que couber, aos direitos dos artistas intérpretes ou executantes, dos produtores fonográficos e das empresas de radiodifusão. Parágrafo único. A proteção desta Lei aos direitos previstos neste artigo deixa intactas e não afeta as garantias asseguradas aos autores das obras literárias, artísticas ou científicas." [grifo nosso] 
passa a protegê-lo por meio da proteção à sua obra, conferida por direitos morais e patrimoniais. Já o substrato comum de onde retirou a inspiração significa o domínio público (a vida em sociedade, a natureza, ou mesmo a leitura inconsciente do apanhado de obras autorais com as quais teve contato) e consiste em exceção aos direitos autorais. $\mathrm{Na}$ lei autoral brasileira são consideradas obras em domínio público aquelas cujo prazo de proteção já expirou, as de autores falecidos que não tenham deixado sucessores e de autores desconhecidos (ressalvada a proteção legal aos conhecimentos étnicos e tradicionais) ${ }^{58}$.

Além da exceção do domínio público, a lei prevê a incidência de limitações aos direitos autorais, objetivando assegurar o interesse público de acesso às obras, representado por determinadas utilizações predeterminadas, listadas nos artigos 46, 47 e 48 da Lei n. ${ }^{\circ} 9.610 / 98^{59}$.

58 LDA, art. Art. 45. Além das obras em relação às quais decorreu o prazo de proteção aos direitos patrimoniais, pertencem ao domínio público:

I - as de autores falecidos que não tenham deixado sucessores;

II - as de autor desconhecido, ressalvada a proteção legal aos conhecimentos étnicos e tradicionais".

59 LDA, Art. 46. Não constitui ofensa aos direitos autorais:

I - a reprodução:

a) na imprensa diária ou periódica, de notícia ou de artigo informativo, publicado em diários ou periódicos, com a menção do nome do autor, se assinados, e da publicação de onde foram transcritos;

b) em diários ou periódicos, de discursos pronunciados em reuniões públicas de qualquer natureza;

c) de retratos, ou de outra forma de representação da imagem, feitos sob encomenda, quando realizada pelo proprietário do objeto encomendado, não havendo a oposição da pessoa neles representada ou de seus herdeiros;

d) de obras literárias, artísticas ou científicas, para uso exclusivo de deficientes visuais, sempre que a reprodução, sem fins comerciais, seja feita mediante o sistema Braille ou outro procedimento em qualquer suporte para esses destinatários;

II - a reprodução, em um só exemplar de pequenos trechos, para uso privado do copista, desde que feita por este, sem intuito de lucro;

III - a citação em livros, jornais, revistas ou qualquer outro meio de comunicação, de passagens de qualquer obra, para fins de estudo, crítica ou polêmica, na medida justificada para o fim a atingir, indicando-se o nome do autor e a origem da obra;

IV - o apanhado de lições em estabelecimentos de ensino por aqueles a quem elas se dirigem, vedada sua publicação, integral ou parcial, sem autorização prévia e expressa de quem as ministrou;

V - a utilização de obras literárias, artísticas ou científicas, fonogramas e transmissão de rádio e televisão em estabelecimentos comerciais, exclusivamente para demonstração à clientela, desde que esses estabelecimentos comercializem os suportes ou equipamentos que permitam a sua utilização;

VI - a representação teatral e a execução musical, quando realizadas no recesso familiar ou, para fins exclusivamente didáticos, nos estabelecimentos de ensino, não havendo em qualquer caso intuito de lucro;

VII - a utilização de obras literárias, artísticas ou científicas para produzir prova judiciária ou administrativa;

VIII - a reprodução, em quaisquer obras, de pequenos trechos de obras preexistentes, de qualquer natureza, ou de obra integral, quando de artes plásticas, sempre que a reprodução em si não seja o objetivo principal da obra nova e que não prejudique a exploração normal da obra reproduzida nem cause um prejuízo injustificado aos legítimos interesses dos autores.

Art. 47. São livres as paráfrases e paródias que não forem verdadeiras reproduções da obra originária nem lhe implicarem descrédito.

Art. 48. As obras situadas permanentemente em logradouros públicos podem ser representadas livremente, por meio de pinturas, desenhos, fotografias e procedimentos audiovisuais". 
Se, por seu lado, o autor vê protegida sua obra e recompensados seus interesses patrimoniais, a sociedade, por sua vez, busca acesso à cultura. Nasce daí um conflito de interesses "igualmente legítimos, igualmente inafastáveis, que o Estado deve atender de maneira igualmente satisfatória para ambos $60 "$. E essa é a função da limitação ao direito autoral, da qual parte-se do pressuposto que nenhum direito é absoluto a ponto de excluir o interesse público. Daí porque, para alguns específicos usos, limita-se o exercício dos direitos patrimoniais por parte dos titulares de direitos autorais.

Como advento da tecnologia (e isso será explorado no decorrer deste estudo), existe o entendimento de que o rol taxativo do artigo 46 não cumpre com o objetivo de, ao mesmo tempo, contemplar ambos os interesses, motivo pelo qual surgiu movimento, em nosso país, para a modificação de tal artigo. Assim, a ABPI (Associação Brasileira da Propriedade Intelectual ${ }^{61}$ ) sugeriu que seja promovida alteração em tal artigo, com a adoção de conceito similar ao do "uso justo" (fair use), oriundo do sistema estadunidense, com o que a redação passaria a ser a seguinte:

\footnotetext{
Art. 46. Não constitui ofensa aos direitos autorais, a reprodução parcial ou integral, a distribuição e qualquer forma de utilização de obras intelectuais que, em função de sua natureza, atenda a dois ou mais dos seguintes princípios, respeitados os direitos morais previstos no art. 24:

I - tenha como objetivo, crítica, comentário, noticiário, educação, ensino, pesquisa, produção de prova judiciária ou administrativa, uso exclusivo de deficientes visuais em sistema Braile ou outro procedimento em qualquer suporte para esses destinatários, preservação ou estudo da obra, ou ainda, para demonstração à clientela em estabelecimentos comerciais, desde que estes comercializem os suportes ou equipamentos que permitam a sua utilização, sempre na medida justificada pelo fim a atingir;

II - sua finalidade não seja essencialmente comercial para o destinatário da reprodução e para quem se vale da distribuição e da utilização das obras intelectuais; III - o efeito no mercado potencial da obra seja individualmente desprezível, não acarretando prejuízo à exploração normal da obra;

Parágrafo Único - A aplicação da hipótese prevista no inciso II deste artigo não se justifica somente pelo fato de o destinatário da reprodução e quem se vale da distribuição e da utilização das obras intelectuais ser empresa ou órgão público, fundação, associação ou qualquer outra entidade sem fins lucrativos.
}

\footnotetext{
60 MANSO, Direito autoral..., p.90.

61 Resolução ABPI n. ${ }^{\circ}$ 67, de 2005.
} 
Tal redação é interessante, por trocar enunciado objetivo por outro subjetivo, motivo pelo qual remete ao Poder Judiciário, mediante o caso em concreto e a aplicação da jurisprudência, a incumbência de definir os parâmetros aceitáveis, os quais, inclusive, são essencialmente mutáveis em vista das mudanças sociais. Por outro lado, o sistema jurídico estadunidense é baseado justamente na Case Law e o que temos de mais parecido com isso é a súmula vinculante.

Ressalte-se que a Convenção de Berna, na revisão de 1967, em seu artigo 9(2) houve por bem limitar a aplicação das exceções (e limitações) aos direitos autorais por meio do chamado "three steps test", que consiste em verificar a aplicação: i) em casos especiais; ii) quando a reprodução não prejudique a exploração normal da obra; e iii) que a reprodução não cause prejuízo injustificado aos legítimos interesses do autor.

\subsubsection{A Dicotomia dos Sistemas de Proteção aos Direitos Autorais: Continental versus copyright}

São dois os sistemas de proteção aos direitos autorais, o latino-germânico, também denominado continental, oriundo do droit d'auteur francês, baseado no "princípio do criador", e o do copyright, baseado no "princípio da proteção do investimento" 62.

No sistema do direito de autor da Europa continental, o que se protege de forma primeira é o criador, pessoa física, por meio da proteção à sua obra, a qual representa traço indissociável de sua personalidade, portanto é o único titular originário. Há a prevalência do direito moral sobre o direito patrimonial.

Segundo Alexandre Dias Pereira, "o princípio do criador significa que o droit d'auteur é apenas destinado a proteger o autor pelas suas criações intelectuais pessoais no

62 Para Alexandre Dias Pereira, "assim, o copyright protegeria os investimentos dos criadores e dos produtores, em ordem à comercialização nos mercados nacionais e internacionais dos produtos que criam, tratando-se de uma concepção destinada a acautelar, em primeira linha, os interesse econômicos dos agentes envolvidos, não sendo protegida a personalidade dos criadores senão na medida em que não entravasse a comercialização dos objectos protegidos pelo copyright. No cerne do copyright estariam as obras (works), em torno das quais gravitariam os criadores em condições de paridade com os produtores e outros agentes de exploração econômica das obras; sendo que, apesar da sua posição comparativamente mais fraca nas relações negociais, os autores não beneficiariam de qualquer protecção legal especial, ficando entregues aos princípios da autonomia da vontade e da liberdade contratual (freedom of contract), e restando-lhes o recurso, em situações de impotência, aos meios jurídicos gerais do Common Law" (PEREIRA, Informática, direito..., p.97). 
domínio da literatura, da ciência e da arte ${ }^{63}$. As criações do espírito deverão ser originais e exprimir a personalidade do autor".

O sistema do copyright, introduzido pela Inglaterra e adotado também pelos Estados Unidos e demais países que adotam o sistema da common law, notadamente aqueles pertencentes à Commonwealth ${ }^{64}$, significa, de forma sintética, o "direito de cópia"65 ou a reserva, em exclusivo, do mesmo.

Tal sistema pode ser considerado como o substituto direto do sistema de privilégios, pelo seu caráter comercial, monopolista e patrimonial, no passo em que pode não beneficiar diretamente o autor, pela possibilidade da concessão de direitos originários a terceiros, inclusive pessoas jurídicas. Só recentemente, em 1988 na Inglaterra e em 1990 nos Estados Unidos, sobreveio o reconhecimento do direito moral ${ }^{66}$, e mesmo assim restrito a determinados segmentos, como forma de auxiliar na harmonização dos sistemas de direito autoral ${ }^{67}$.

63 O autor faz tal afirmação com base nas leis autorais alemã e francesa: $\S 1$ UrhG: "Die Urheber von Werken der Literatur, Wissenschaft und Kunst genießen für ihre Werke Schutz [...]"; § 11 UrhG: "Das Urheberrecth schützt den Urheber in seinen geistigen und persönlichen Beziehungen zum Werk und in der Nutzung des Werkes".

Art. L. 111-1 CPI: "L'auteur d'une œuvre de l'esprit jouit sur cette œuvre, du Seul fait de la création, d'un droit de propriété incorporelle exclusif et opposable à tous"; Art. L. 112-1 CPI: "Les dispositions du présent code protègent les droits des auteurs sur toutes les ouvres de l'esprit, quels qu'en soient le genre, la forme d'expression, le mérite ou la destination". (PEREIRA, Informática, direito..., p.98-99).

64 A Commonwealth é uma associação de 53 estados independentes que deliberam e colaboram nos interesses comuns de seus povos e na promoção de entendimento internacional e paz mundial. 1,8 bilhões de cidadãos da Commonwealth, aproximadamente 30 por cento da população mundial, são compostos por grande variedade de crenças, raças, culturas e tradições. (Disponível em: <http://www.thecommonwealth.org/Internal/ 20596/about_us/. Acesso em: 16 ago. 2006). Tradução livre de: "The Commonwealth is an association of 53 independent states consulting and co-operating in the common interests of their peoples and in the promotion of international understanding and world peace. The Commonwealth's 1.8 billion citizens, about 30 per cent of the world's population, are drawn from the broadest range of faiths, races, cultures and traditions".

65 Segundo o dicionário Aurélio, Copyright ou copirraite é o "direito exclusivo de imprimir, reproduzir ou vender obra literária, científica ou artística". A definição da Organização Mundial da Propriedade Intelectual (OMPI) para copyright é de que "is a legal term describing rights given to creators for their literary and artistic works" (Definição extraída do sítio internet disponível em: $<$ http://www.wipo.int/aboutip/en/copyright.html>. Acesso em: 28 maio 2006).

66 "Enquanto que o sistema de copyright tem vindo paulatinamente a reconhecer os direitos morais, no sistema de direito de autor a primazia concedida à protecção do laço existente entre a obra e o seu criador tem conduzido ao triunfo dos direitos morais sobre as considerações de teor econômico". (AKESTER, Patrícia. O direito de autor e os desafios da tecnologia digital. Cascais: Principia, 2004. p.35).

67 Muito embora desde a última revisão da Convenção de Berna, em 1971, já se note uma aproximação dos sistemas, somente recentemente, já com a chamada "revolução digital", e sob a égide do acordo TRIPS, vem sendo, de certa maneira, atingida a pretendida conciliação dos sistemas de proteção ao direito de autor. 
Fronçoise Benhamou e Joëlle Farchy reforçam as principais linhas de ruptura entre os sistemas:

\begin{abstract}
O copyright, mesmo sendo fundado em um princípio constitucional, tem natureza utilitária e econômica antes de ser ancorado no campo jurídico, enquanto, ao contrário, podemos dizer que o jurídico prima pela economia em relação ao direito de autor. Os Estados Unidos, o Reino Unido, a Irlanda, e ainda em certa medida os Países Baixos e os países Nórdicos adotaram o sistema do copyright. Os direitos são atribuídos àquele que assume o risco econômico para arcar com o financiamento da criação. Foi assim que Orson Welles, numa brincadeira um pouco dolorosa, percebeu que o autor de Citizen Kane foi a RKO em 1941 e, por conseqüência, outros produtores que não ele mesmo. Por outro lado, nos países inspirados pela noção do direito 'à francesa', o direito de autor remete à pessoa (ou às pessoas) à origem da criação, e os direitos são atribuídos aos seus únicos criadores; eles se vinculam à pessoa física e não à pessoa física ou moral do produtor/financiador.

O segundo elemento da oposição é característico ao direito moral, teoricamente ausente do copyright. Com efeito, no caso do copyright, a obra (e suas explorações presentes e futuras) premia, enquanto o autor está no coração da construção jurídica do direito de autor, em uma visão romântica do que constitui a essência do direito moral. As modalidades de aplicação divergem enfim: para o copyright, um registro é necessário, como para a patente, enquanto na França a proteção ao direito de autor se aplica naturalmente, independente de registro, a todas as obras realizadas sob certos parâmetros reconhecidos pela lei. A obrigação do registro para o copyright, contudo, foi perdendo força em 1989.68
\end{abstract}

Apesar de os sistemas correrem em paralelo, cada Estado passou a proteger, no plano normativo interno, os interesses dos seus autores e (ou) "investidores autorais", quer pela justificativa do incentivo ao potencial criativo por meio das garantias necessárias à

68 Tradução livre de: "Les grandes lignes de clivage. Le copyright, même s'il est fondé sur um príncipe constitutionnel, est de nature utilitariste et économique avant que d'être ancré dans le champ du juridique, tandis qu'a l'inverse on peut avancer que lê juridique prime sur l'economique avec le droit d'auter. Les États-Unis, le Royaume-Uni, l'Irlande, et aussi dans une certaine mesure les Pays-Bas et les pays nordiques ont adopté le système du copyright. Les droits sont attributes à celui qui assume le risque économique en prenant en charge le financement de la creation. C'est ainsi que Orson Welles, dans une boutade un peu amère, remarquait que les auteurs de Citizen Kane étaint la RKO en 1941, d'autres producteurs par la suite, et non pas lui-même. En revanche, dans les pays inspires par la notion de droit 'a la française' le droit d'auter renvoie à la personne physique et non à la personne physique ou morale du producteur/financeur.

Le second element de l'opposition a trait au droit moral, théoriquement absent du copyright. Em effet, dans lê cas du copyright, l'ouvre (et sés exploitations presentes et à venir) prime, tandis que l'auteur est au cour de la construction juridique du droit d'auteur, dans une vision romantique qui constitue le terreau du droit moral. Les modalités d'application divergent enfin: pour le copyright, un dépôt est nécessaire, comme pour le brevet, tandis qu'en France la protection par le droit d'auteur s'applique naturellement, indépendamment de tout dépôt, à toutes les œuvres réalisées sur certains types de support reconnus par la loi. L'obligation de deposer une notice pour le copyright a toutefois éte alégée en 1989." (BENHAMOU, Françoise; FARCHY, Joëlle. Droit d'auteur et copyright. Paris: La Découverte, 2007. p.21-22). 
produção cultural, para assegurar independência e dignidade aos criadores e intérpretes ${ }^{69}$, quer pelo incentivo às ciências e às artes.

Diferem os fundamentos filosóficos ${ }^{70}$ dos sistemas de proteção dos direitos autorais, notadamente no aspecto da proteção moral do criador, fortalecida no direito autoral denominado continental ${ }^{71}$, o qual apresenta maior abrangência do que o copyright ${ }^{72}$.

Tal distinção entre os sistemas de proteção aos direitos autorais é relevante para o presente estudo, na medida em que as diferenças, mesmo as filosóficas, historicamente repercutiram nas crises dos direitos autorais na música, amplificando, em especial, a atual crise, em vista do caráter transnacional da internet, que rompeu com a noção de fronteiras físicas para estabelecer a idéia de fronteiras virtuais.

Daí porque urge a harmonização ${ }^{73}$ dos sistemas, entretanto se levando em conta que "a harmonização de duas tradições jurídicas com raízes tão distintas não poderá ter lugar em termos de prevalecimento da concepção de um dos dois sistemas sobre a outra"74,

69 Consta do preâmbulo da Diretiva da Comunidade Européia 2001/29/CE: "(11) Um sistema rigoroso e eficaz de protecção do direito de autor e direitos conexos constitui um dos principais instrumentos para assegurar os recursos necessários à produção cultural europeia, bem como para garantir independência e dignidade aos criadores e intérpretes".

70 Para análise da natureza jurídica do direito de autor, v. LIPSZYC, Derecho de autor..., p.18-27; CHAVES, Direito do autor..., p.8-16.

71 Para Christophe Caron, "ainsi, est possible de constater l'importance sans cesse grandissante du système anglo-saxon du copyright, qui répond à une philosophie différente de celle du droit d'auteur, notamment par la place très secondaire qu'il accorde aux prérogatives Morales du créateur. De plus, le droit d'auteur s'industrialise sous l'effet, notamment, de la consommation de masse des produits cultureles. De ce fait, les logiques économiques tendent à dominer les exigences personnalistes. C'est pourquoi le droit d'auteur, apparaît de plus en plus comme um droit em péril, comme une discipline menacée dans sés fondaments et dans son génie." (CARON, Christophe. Abus de droit et droit d'auteur. Paris: LITEC, 1998. p.4-5).

72 É a constatação de Victorio de Sanctis: "...gli Stati Uniti, fedeli al principio di proteggere solo il diritto di copia (Copyright) e non il più complesso ed ampio diritto dell'autore ...". (SANCTIS, I soggetti..., p.44).

73 A harmonização dos sistemas constitui objetivo da Comunidade Européia, como consta do preâmbulo da Diretiva 2001/29/CE: "(1) O Tratado prevê o estabelecimento de um mercado interno e a instituição de um sistema capaz de garantir o não falseamento da concorrência no mercado interno. A harmonização das legislações dos Estados-Membros em matéria de direito de autor e direitos conexos contribui para a prossecução destes objectivos". O Tratado que se menciona é o de Constituição da Comunidade Européia.

74 Para essa assertiva, Alexandre Dias Pereira se apóia em autora alemã, a qual afirma: "Eine Harmonisierung zweier Rechtstraditionen mit so unterschiedlicher Grundausrichtung wird jedenfalls nicht so ablaufen können, daß einem der beiden Systeme die Ideologie des anderen gleichsam übergestülpt wird". (ELLINS, Julia. Copyright Law, Uhreberrecht und ihre Harmonisierung in der Europäischen Gemeinschaft (von den Anfängen bis ins Informationszeitalter). Berlim: Duncker \& Humblot, 1997. p.234 apud PEREIRA, Informática, direito..., p.106, nota de rodapé 195). 
como ocorre na atualidade, com a tentativa de sobreposição dos dispositivos do copyright em questões que envolvem a internet.

Tal tentativa de prevalecimento é especialmente perceptível em escritos de autores estadunidenses, que não levam em conta as diferenças essenciais entre os sistemas de proteção, pelo que propõem soluções para problemas cujas intensidades se revelam muito menores no sistema do direito de autor latino-germânico. Sobre isso adiante será visto nesta tese.

\subsection{A INSTALAÇÃO DA INDÚSTRIA FONOGRÁFICA}

Remonta a meados do século XIX o marco inicial das periódicas (r)evoluções que dizem respeito à música, alçada de privilégio para uns poucos abastados à popularização ${ }^{75}$, pois num período anterior à invenção das tecnologias de gravação de sons o que fazia disseminá-la eram as partituras impressas e as interpretações por músicos.

Para Marcia Tosta Dias, "alguns autores creditam às partituras e a um de seus reprodutores, o piano, as origens da 'música de massa"'76 e que "os editores teriam sido então os primeiros empresários fonográficos, constituindo verdadeiros centros de comércios de edições"77 e:

por mais que favorecessem amplamente a difusão musical, as partituras apresentavam um limite característico de toda mercadoria musical, independentemente do seu formato: a necessidade de mediação por uma máquina ou instrumento musical e a conseqüente exigência de conhecimento técnico acumulado, em algum momento da reprodução ${ }^{78}$.

75 "L'histoire de la musique du 20ème siècle est indissociable de celle des techniques qui lui ont permis d'exister et de se déveloper. Les modes de production et de diffusion du son ont ouvert des champs nouveax à la création musicale, dont il est encore aujourd'hui difficile de mesurer toute l'ampleur. Le bouleversement le plus considérable provient certainement de l'avènement de techniques de diffusion à grande èchelle de la musique: celles-ci ont abouti à de nouveax modes de consummation qui ont affecté la nature meme de la musique tout en créant des circuits économiques nouveaux adaptés à la production de musique enregistrée et à sa diffusion à grande échelle." (BERTRAND, La musique..., p.25).

76 DIAS, Marcia Tosta. Os donos da voz: indústria fonográfica brasileira e mundialização da cultura. São Paulo: Boitempo, 2000. p.33.

77 DIAS, Os donos da voz..., p.33. Nesse aspecto, informam Vittorio M. de Sanctis e Mario Fabiani que "dopo l'invenzione della 'notazione neumatica sul rigo' di Guido d'Arezzo (sec. XI), l'industria editoriale della musica si è mossa sulla falsa riga dell'editoria libraria per la pubblicazione e la diffusione delle opere musicale". (DE SANCTIS, Vittorio M.; FABIANI, Mario. I contratti di Diritto di Autore. Milão: Giuffrè, 2000. p.210).

78 DIAS, Os donos da voz..., p.33. 
Já se tinha, naqueles tempos longínquos, notícia de infrações ao direito de autor ${ }^{79}$ relacionadas à contrafação de partituras musicais, muito embora na lei não houvesse menção expressa à obra musical ${ }^{80}$, mas somente à obra literária. Em decorrência disso, houve evolução legislativa em diversos países no sentido de incluir a proteção de obras às obras artísticas, categoria na qual a música se inclui, de modo que, em 1886, ano da Convenção de Berna, diploma condutor do direito autoral, já era pacífico o entendimento pela inclusão da obra musical como protegida, mesmo que sob o manto da proteção das partituras.

\subsubsection{A Primeira Crise: A Invenção dos Meios de Fixação de Sons}

Em 1877, Thomas Alva Edison inventou o fonógrafo, aparelho que gravava sons em um cilindro e posteriormente os fazia executar, o que constituiu marco na música, visto ter introduzido a possibilidade, mesmo que rudimentar, de se fixar obras musicais para posterior audição ${ }^{81}$.

79 Estipula-se, desde já, que no presente estudo as expressões "direito de autor" e "direitos de autor" serão utilizadas quando se tratar do instituto per se, com a pluralidade de situações jurídicas ativas e passivas que compõem o seu conteúdo; e que a expressão "direitos autorais" será utilizada quando o objeto tratado for o do "direito de autor" em conjunto com aqueles que lhe são conexos, o que se faz por força do contido na Lei n. ${ }^{\circ}$ 9.610/98, Art. 1. ${ }^{\circ}$ "Esta Lei regula os direitos autorais, entendendo-se sob esta denominação os direitos de autor e os que lhes são conexos". Estipula-se, também, que poderão ser utilizadas as iniciais LDA (iniciais de Lei dos Direitos Autorais) para indicar a Lei n. ${ }^{\circ}$ 9.610/98. Será utilizada a expressão "direito autoral" para designar a disciplina.

80 Tem-se conhecimento de que o mais antigo privilégio para impressão e venda de partitura musical foi concedido, em 25 de Maio de 1498, da República de Veneza para Ottaviano dei Petrucci, pelo prazo de 20 anos. A música, na época, recebeu proteção não per se mas pelo fato de estar fixada em papel, sob forma de obra literária. No direito inglês, o primeiro caso de reconhecimento judicial da proteção da obra musical pelo copyright se deu por decisão prolatada em 18 de março de 1773, mesmo que restrita à declaração de ilicitude da "multiplicação de cópias de material impresso", na ação proposta por Johann Christian Bach, filho mais novo de J.S. Bach, em conjunto com Carl Friedrich Abel, ao descobrirem a publicação indevida de exercícios e sonata de suas autorias pela editora Longman \& Lukey. Martin Kretschmer e Friedemann Kawohl transcreveram o que Cowper relatou sobre o entendimento da Corte no caso: "The words of the Act of Parliament are very large: 'books and other writings'. It is not confined to language or letters. Music is a science; it may be written; and the mode of conveying the ideas, is by signs and marks. A person may use the copy by playing it, but he has no right to rob the author of the profit, by multiplying copies and disposing of them for his own use." (KRETSCHMER, Martin; KAWOHL, Friedemann. The History and Philosophy of Copyright. In: FRITH, Simon; MARSHALL, Lee (Orgs.). Music and Copyright. 2.ed. Edimburgo: Edinburgh University Press, 2004. p.23 e 35).

81 Para leitura acerca da trajetória do universo da gravação, Amaro Moraes e Silva Neto desenvolveu um "museu virtual", o qual denominou de "Odisséia do Som" (Disponível em: <http://www.odisseiadosom.com.br>. Acesso em: 10 out. 2007). 
Dez anos após a descoberta de Edison, o alemão Emil Berliner inventou o gramofone, aparelho que reproduzia discos planos gravados, com melhores atributos técnicos que os cilindros do fonógrafo. $O$ prático formato de tal meio de fixação possibilitava a confecção de um número virtualmente ilimitado de cópias, elaboradas a partir de uma matriz, o que contribuiu para que tal invenção se tornasse mais popular do que o fonógrafo e, conseqüentemente, sua tecnologia fosse aprimorada.

A intenção de Berliner era possibilitar a disseminação da cultura, por meio do acesso à música clássica a um número maior de pessoas, pois o ingresso aos locais de concertos era limitado àqueles que faziam parte da elite cultural e econômica. $\mathrm{O}$ fato é que tal invenção abriu um extraordinário campo de difusão das obras musicais ${ }^{82}$.

Tendo patenteado sua invenção nos Estados Unidos, em 1888 Berliner voltou à Alemanha onde, em sua cidade natal, fundou em 1898, a empresa Deutsche Grammophon Gesellschaft, primeira fábrica para produção de discos, a qual, no espaço de dez anos, já fabricava milhões de unidades por ano ${ }^{83}$.

A tecnologia presente nesse período inaugural das máquinas de sons não permitia que o número de músicas a ser incluído em um álbum fosse significativo nem que a correspondente duração fosse completa, já que a capacidade de gravação era de aproximadamente dois minutos, de forma com que eram gravados somente os trechos considerados principais. Pelo mesmo motivo, houve significativa alteração no processo criativo da composição, já que se passou a adequar sua duração para tal reduzido tempo de gravação.

Dentre os pioneiros a gravar seus discos com a novel tecnologia estavam o tenor italiano Enrico Caruso, o baixo russo Feodor Chaliapin e a "prima-dona" dos palcos de ópera Nellie Melba. É curioso notar que esta última, ao comentar o sucesso dos discos gravados em 1904, afirmou que: "uma das particularidades que o gramofone trouxe à

82 "Infatti, quando alla fine del Secolo XIX, fu inventato il primo metodo meccanico capace di registrare e riprodurre fedelmente $i$ suoni, si aprì per la musica un nuovo straordinario campo di diffusione che ovviamente dette vita a nuovi rapporti." (DE SANCTIS e FABIANI, I contratti..., p.211).

83 Cf. Autor desconhecido. "Qualidade absoluta. Do gramofone ao CD". Artigo publicado no sítio do Deutsche Welle no dia 20/09/2003, na seção de Cultura (Disponível em: <http://www.dw-world.de/ $\mathrm{dw} /$ article/0,2144,971608,00.html>. Acesso em: 12 nov. 2006). 
minha vida foi toda uma série de pedidos de casamento de gente que ouvira minhas gravações, porém jamais me vira"84.

Foi esse o cenário inicial do segmento fonográfico, mas suficiente para gerar sentimentos de estupefação na sociedade e se transformar em motivo de preocupação aos autores e investidores musicais, em termos mundiais.

Em 9 de setembro de 1886 foi firmada a Convenção de Berna para a Proteção de Obras Literárias e Artísticas, principal diploma do direito de autor, constantemente atualizada $^{85}$. Nela foram convencionados três princípios básicos ${ }^{86}$ :

(a) Obras originadas de um dos estados contratantes (que significa, obras cujo autor é nacional de tal Estado ou obras que foram antes publicadas em tal Estado) devem receber a mesma proteção em cada um os outros Estados contratantes como é garantida às obras de seus próprios nacionais (princípio do 'tratamento nacional').

84 Cf. Autor desconhecido. "Qualidade absoluta. Do gramofone ao CD". Artigo publicado no sítio do Deutsche Welle no dia 20/09/2003, na seção de Cultura. Disponível em: <http://www.dw-world.de/ dw/article/0,2144,971608,00.html>. Acesso em: 12 nov. 2006).

85 Foi objeto de revisão em Paris (1896) e Berlim (1908), complementada em Berna (1914), revisada em Roma (1928), Bruxelas (1948), Estocolmo (1967) e em Paris (1971), com emenda em 1979. Tais revisões buscam atualizar a norma em função das mudanças sociais e dos avanços tecnológicos. Para Alexandre Dias Pereira, "o passado do direito de autor é um processo contínuo de adaptação a novas realidades tecnológicas. (...). A fotografia, as gravações sonoras, a radiodifusão, o cinema, são apenas alguns dos exemplos de meios tecnológicos que permitiram novas formas de criação e de exploração de obras. $\mathrm{O}$ direito de autor assimilou estas novas tecnologias, ainda que por vezes essa protecção tenha sido complementada através de direitos conexos e figuras afins". (PEREIRA, Informática, direito..., p.25).

86 Informações constantes no sítio internet da Organização Mundial da Propriedade Intelectual - OMPI (Disponível em: <http:/www.wipo.int/treaties/en/ip/berne/summary_berne.html>. Acesso em: 28 maio 2006). Tradução, pelo autor, de "The three basic principles are the following: (a) Works originating in one of the contracting States (that is, works the author of which is a national of such a State or works which were first published in such a State) must be given the same protection in each of the other contracting States as the latter grants to the works of its own nationals (principle of 'national treatment'). (b) Such protection must not be conditional upon compliance with any formality (principle of 'automatic' protection). (c) Such protection is independent of the existence of protection in the country of origin of the work (principle of the 'independence' of protection). If, however, a contracting State provides for a longer term than the minimum prescribed by the Convention and the work ceases to be protected in the country of origin, protection may be denied once protection in the country of origin ceases." Para Alexandre Dias Pereira: "Em termos gerais, os três princípios fundamentais analisam-se nos seguintes termos. Primeiro, o princípio do tratamento nacional, nos termos do qual, as obras tendo por origem um dos Estados contraentes (isto é, as obras cujos autores são nacionais ou residentes habituais de um desses Estados ou que foram aí publicados pela primeira vez) devem beneficiar em cada um dos outros Estados contraentes da mesma protecção que aí é atribuída às obras dos seus próprios nacionais. Segundo, o princípio da protecção automática, que significa que a protecção não deve ser sujeita a qualquer formalidade (por ex., registo, depósito). Terceiro, o princípio da independência da protecção, segundo o qual esta protecção é independente da existência de protecção no país de origem da obra, embora a protecção possa ser recusada, em certos termos, se tiver cessado no país de origem, no caso em que um Estado contraente prevê uma duração mais longa do que o mínimo prescrito pela Convenção e a obra cessou de ser protegida no país de origem." (PEREIRA,. Informática, direito..., p.94). 
(b) Tal proteção não será condicional à submissão a qualquer formalidade (princípio da 'proteção automática').

(c) Tal proteção independe da existência de proteção no país de origem do trabalho (princípio da 'independência da proteção). Se, entretanto, um Estado contratante garante prazo maior do que o mínimo estabelecido pela Convenção e a obra deixa de ser protegida no país de origem, a proteção pode ser negada uma vez que a proteção no país de origem se encerrou.

As leis nacionais promulgadas na seqüência da Convenção de Berna buscaram enfrentar diversas situações que envolviam a obra musical, imprevistas na ocasião daquele diploma internacional. No caso brasileiro, em 1 de agosto de 1898, foi sancionada a Lei n. ${ }^{\circ} 496$, que expressamente incluía no conceito de "obra litteraria, scientifica ou artistica" as obras "musicaes ou dramatico-musicaes, composições de musica com ou sem palavras".

Em 1 de janeiro de 1916 foi promulgada a Lei n. ${ }^{\circ}$ 3.071, que instituiu o Código Civil, com capítulo destinado à "propriedade literária, artística e científica". Nessa codificação, a obra musical se encontrava sob o manto geral da "obra artística", a cujo autor era atribuído o direito exclusivo de reprodução - conforme disposto no artigo 64987 - sendo-lhe concedida ampla proteção, independentemente da qualidade de sua obra ${ }^{88}$; assim, não importava o senso estético, mas tão-somente, conforme o firme entendimento doutrinário do direito de autor, bastava que houvesse a originalidade, fruto da concepção criativa da inteligência humana.

Eram três os artigos do Código Civil de 1916 que especificamente versavam sobre música: os artigos 655,657 e 658.

O artigo 655 previa que "o autor de composição musical, feita sobre texto poético, pode executá-la, publicá-la ou transmitir o seu direito, independente de autorização do escritor, indenizando, porém, a este que conservará direito a reprodução do texto sem a música". É interessante notar que se limitava o direito de autor do escritor de poemas quando o compositor desejasse tomar tal obra como substrato para a sua criação musical,

87 Lei n. ${ }^{\circ}$ 3.071/16, "Art. 649. Ao autor de obra literária, científica, ou artística pertence o direito exclusivo de reproduzi-la".

88 Aponta J.M. de Carvalho Santos que "para os efeitos do direito de propriedade sobre as produções literárias, científicas e artísticas, a lei não distingue nada quanto ao seu valor e à sua importância. Desde o momento em que uma obra é creada, e protegida. Não exige a lei que se trate de uma obra prima. Uma obra abaixo de medíocre tem igual amparo legal. E tanto a lei protege o autor de um tratado científico, de um romance notavel ou de uma ópera sublime, como aquele outro autor de um simples folheto de reclame, de um romance desses de porta de engraxate, ou de uma cançoneta popular" (SANTOS, J. M. de Carvalho. Código civil brasileiro interpretado. 3.ed. Rio de Janeiro: Freitas Bastos, 1943. v.8. p.405). 
que bem poderia ser de modo integral ou da forma desejada pelo compositor, desde que aquele fosse indenizado.

O artigo 657 previa a limitação do direito de autor do compositor em relação à utilização isenta de lucro: "publicada e exposta à venda uma obra teatral ou musical, entende-se anuir o autor a que se represente, ou execute, onde quer que a sua audição não for retribuída".

Era o teor do artigo 658: "aquele que, com autorização do compositor de uma obra musical, sobre os seus motivos escrever combinações, ou variações, tem, a respeito destas, os mesmos direitos, e com as mesmas garantias, que sobre aquela o seu autor".

Da leitura dos dispositivos é perceptível a valorização de determinada forma artística (música) em detrimento de outra (poesia) ${ }^{89}$, uma vez que, conforme já visto, enquanto o artigo 655 autorizava a utilização compulsória remunerada de obra poética preexistente para a criação de composição musical, o artigo 658 explicitava a necessidade de autorização do compositor para que uma nova obra fosse criada com base na original.

Em 2 de janeiro de 1924 foi publicado o Decreto n. ${ }^{\circ} 4.790$, que ampliou a inteligência do artigo 657 do Código Civil e instaurou minúcias para a defesa dos direitos autorais na música. Houve, entretanto, sensível mudança no enfoque, visto que da codificação constava o permissivo legal à utilização não-remunerada ${ }^{90} \mathrm{e}$, no decreto, a tônica era a sanção à utilização remunerada não-autorizada ${ }^{91}$, numa primária demonstração do direcionamento do sistema de propriedade intelectual, recorrente até os dias atuais.

Assim, as leis de 1898, de 1916 e o decreto de 1924, no que dizem respeito à música, trataram de questões afetas ao aspecto patrimonial da obra musical, mediante sua comunicação ao público por apresentações ao vivo e mesmo sobre reprodução e distribuição

89 "Neste passo o Código abre uma como que exceção à doutrina, segundo a qual uma peça musicada forma um todo indisivel, levando em conta que a obra musical tem vida própria e, em certo sentido, é de mais valor do que a parte poética." (SANTOS, J. M. de C., Código civil..., p.434).

90 Lei n. ${ }^{0}$ 3.071/16: "Art. 657 publicada e exposta à venda uma obra teatral ou musical, entende-se anuir o autor a que se represente, ou execute, onde quer que a sua audição não for retribuída".

91 Decreto n. ${ }^{\circ}$ 4.790/24: "Art. 2. ${ }^{\circ}$ Nenhuma composição musical, tragedia, drama, comedia ou qualquer outra producção, seja qual fôr a sua denominação, poderá ser executada ou representada em theatros ou espectaculos publicos, para os quaes se pague entrada, sem autorização, para cada vez, do seu autor, representante, ou pessôa legitimamente subrogada nos direitos daquelle". 
de partituras, sob o enfoque da propriedade literária, mas não se versou sobre questões que envolvessem a fixação de sons em fonogramas ${ }^{92}$ ou sua comercialização.

O fato é que a novel tecnologia foi disseminada e as fixações em discos de gomalaca para serem utilizados em gramofones já estavam ocorrendo, em quantidade cada vez maior.

Por volta de 1925, a gravação dos discos, antes mecânica, passou a ser realizada mediante processo elétrico, o que resultou em eficiência e velocidade na fabricação, ao mesmo tempo em que se dobrou a capacidade de gravação, de dois minutos para quatro minutos. Tal aprimoramento técnico significou importante fortalecimento da indústria fonográfica, que fabricava os aparelhos leitores e também os discos a serem executados e, em pouco tempo, forte concorrência se estabeleceu e originou onda de importantes fusões entre as principais empresas do setor ${ }^{93}$.

Em paralelo às fantásticas possibilidades trazidas pela nova tecnologia ocorreu a primeira crise no direito de autor, fomentada pelo sentimento de insegurança que passou a afligir os agentes envolvidos no novo modelo de negócios, principalmente os compositores, os artistas e os investidores culturais, dada a imprevisão normativa quanto aos meios de fixação.

Se antes as interpretações musicais eram feitas ao vivo, em lugares restritos, para um número determinável de pessoas, agora poderiam ser simultaneamente realizadas em lugares variados, bastando para isso a utilização de aparelho leitor dos discos, o gramofone.

A música, dessa forma, passou a atingir um público mais significativo, no que se alcançou o objetivo de Emil Berliner. Do mesmo modo, maior número de sujeitos passou a compor o cenário musical, já que, além do compositor, do intérprete, do editor de partituras, do empresário musical (normalmente o proprietário do local, café ou teatro onde

92 LDA: "Art. 5. ${ }^{\circ}$, IX - fonograma - toda fixação de sons de uma execução ou interpretação ou de outros sons, ou de uma representação de sons que não seja uma fixação incluída em uma obra audiovisual". A utilização de tal vocábulo, que deriva do fonógrafo de Edison, demonstra a influência estadunidense, muito embora a tecnologia que efetivamente prosperou foi a do gramofone. Observe-se que mesmo no direito dos tratados tal palavra prevaleceu, já que, segundo a Convenção de Roma para a Proteção dos Intérpretes, Produtores e Organismos de Radiodifusão, de 1961, fonograma significa "qualquer fixação aural exclusiva de uma performance ou de outros sons". A distinção entre a obra musical e o fonograma é relevante: a primeira é a composição em si, objeto de proteção do direito autoral, enquanto que o segundo representa sua fixação e a seu titular corresponde direito conexo ao autoral.

93 Marcia Tosta Dias apresenta quadro indicativo das fusões ocorridas entre 1928 e 1945, que originaram as empresas EMI, RCA-Victor, CBS, Polydor e Phonogram Sobre o assunto, cf. DIAS, Os donos da voz..., p.36. 
era feita a apresentação) e do público espectador, surgiu a figura do produtor musical: ao mesmo tempo investidor, fabricante e distribuidor de obras musicais e dos gramofones.

$\mathrm{O}$ investidor, independentemente do segmento de atuação, busca o retorno sobre o dinheiro aplicado, acrescido de lucro sobre o montante. Almeja, também, que seu investimento seja garantido pela maior segurança possível, mormente por meio de legislação adequada e respeito aos contratos. Foi nesse sentido que, no exterior, os produtores rapidamente obtiveram a garantia legal sobre a titularidade de gravações, primeiro na Inglaterra, a partir do "Copyright Act" de 1911, quando lhes foi concedido o direito único de reprodução, mediante a manufatura de cópias de suas gravações em discos ou cilindros ${ }^{94} \mathrm{e}$, posteriormente, em outros países.

A indústria fonográfica estrangeira, por seus agentes denominados "produtores musicais", passou a pressionar os autores e intérpretes a assinar contratos abusivos, contendo cláusulas que operavam verdadeiras cessões integrais de direitos, camufladas sob o manto da edição, inclusive sobre obras futuras.

A lei brasileira da época, ao contrário da mencionada lei inglesa, não previa a fixação de interpretações de composições musicais, as contratações se operavam sob as regras do contrato de edição ${ }^{95}$, dispostas nos artigos 1346 a 1358 do Código Civil de 1916 e, no que aplicável, sob as regras gerais de direito autoral ${ }^{96}$, especialmente em relação à

94 Copyright Act de 1911: "19.-(1) Copyright shall subsist in records, perforated rolls, and other contrivances by means of which sound may be mechanically reproduced, in like manner as if such contrivances were musical works, but the term of copyright shall be fifty years from the making of the original plate from which the contrivance was directly or indirectly derived, and the person who was the owner of such original plate at the time when such plate was made shall be deemed to be the author of the work, and where such owner is a body corporate, the body corporate shall be deemed for the purposes of this Act to reside within the parts of His Majesty's dominions to which this Act extends if it has established a place of business within such parts." Esse artigo 19 traz, ainda, diversas disposições acerca do copyright em música. Tal lei representou importante marco no direito de autor.

95 "O contrato de gravação de discos é contrato de edição. (...) gravar disco é editar." (PONTES DE MIRANDA, Francisco Cavalcanti. Tratado de direito privado: parte especial. Rio de Janeiro: Borsoi, 1956. Tomo XVI. p.160). Pontes de Miranda percebeu a tendência em se considerar o editor como cessionário de direito real, o que de forma veemente rechaçou, ao esclarecer que "o que se transfere, com o contrato de edição, não é o direito autoral de exploração, mas elemento do exercício dêsse, pela dívida e pela obrigação que assume o titular do direito autoral de exploração. (...) Não há confundir-se a transmissão do direito de edição, ainda que seja de número indeterminado de edições e de exemplares, com a transmissão do direito de propriedade intelectual, ou a constituição de direito real". (PONTES DE MIRANDA, Francisco Cavalcanti. Tratado de direito privado: parte especial. Rio de Janeiro: Borsoi, 1963. Tomo XLIV. p.322 e 327).

96 Para Clóvis Bevilacqua, "as composições teatrais ou musicais, quanto à publicação, regem-se pelas normas que regulam o direito de reprodução dos demais produtos da inteligência" (BEVILACQUA, Clovis. Direito das coisas. 2.ed. atual. Rio de Janeiro: Freitas Bastos, 1946. v.1. p.289). 
cessão de direitos. Na prática significava que o autor, aquele que deveria ser protegido, tinha de submeter-se ao poder da indústria fonográfica, já que o acesso aos meios de produção de discos era limitado, sendo absolutamente necessária a presença daquele que detivesse o capital.

Nesse sentido, especificamente sobre a experiência brasileira, já informava Pedro Vicente Bobbio que:

No Brasil a realidade é, por enquanto, bem mais desfavoravel aos titulares de direito autoral, que as fabricas gravadoras sujeitam a imposições constrangedoras. Sistematicamente as fabricas gravadoras brasileiras (isto é: estabelecidas no Brasil, já que as maiores não são nacionais) contratam as gravações mediante pagamento de regalias fixadas, em nivel que não atinge a 30\% do nivel internacional. Além disso, impõem nos contratos condições leoninas, chegando ao ponto de neles incluirem a cessão do direito de execução pública, do direito de irradiação, do direito de sincronização etc. embora sem qualquer contraprestação especifica. ${ }^{97}$

Nessa fase inicial, as questões concernentes ao direito de autor resumiam-se àquelas correspondentes às atuais definições de publicação ${ }^{98}$, distribuição ${ }^{99}$ e comunicação ao público ${ }^{100}$, sendo que os conceitos atuais de reprodução ${ }^{101}$ e de contrafação ${ }^{102}$ já eram vigentes em relação às obras musicais desde que as partituras eram impressas ou mesmo copiadas à mão.

Por meio de contratos de edição ou ainda de cessão de direitos patrimoniais (direito autoral de exploração, para Pontes de Miranda) firmados com os produtores culturais, o compositor autorizava a fixação de sua obra, por si interpretada ou por terceiro.

97 BOBBIO, O direito de autor..., p.51.

98 LDA: "Art. 5. ${ }^{\circ}$ Para os efeitos desta Lei, considera-se: I - publicação - o oferecimento de obra literária, artística ou científica ao conhecimento do público, com o consentimento do autor, ou de qualquer outro titular de direito de autor, por qualquer forma ou processo."

99 LDA: "Art. 5. ${ }^{\circ}$ Para os efeitos desta Lei, considera-se: IV - distribuição - a colocação à disposição do público do original ou cópia de obras literárias, artísticas ou científicas, interpretações ou execuções fixadas e fonogramas, mediante a venda, locação ou qualquer outra forma de transferência de propriedade ou posse." Necessária a ressalva de que esse conceito de distribuição, ora exposto, foi trazido somente com o tratado TRIPS, de 1996. Naquela primeira fase da indústria fonográfica não se falava, por exemplo, de locação. Tratava-se, mais acertadamente, de uma comercialização do disco contendo o(s) fonograma(s).

100 LDA: "Art. 5. ${ }^{\circ}$ Para os efeitos desta Lei, considera-se: V - comunicação ao público - ato mediante o qual a obra é colocada ao alcance do público, por qualquer meio ou procedimento e que não consista na distribuição de exemplares."

101 LDA: "Art. 5. ${ }^{\circ}$ Para os efeitos desta Lei, considera-se: VI - reprodução - a cópia de um ou vários exemplares de uma obra literária, artística ou científica ou de um fonograma, de qualquer forma tangível, incluindo qualquer armazenamento permanente ou temporário por meios eletrônicos ou qualquer outro meio de fixação que venha a ser desenvolvido."

102 LDA: "Art. 5. Para os efeitos desta Lei, considera-se: VII - contrafação - a reprodução não autorizada." 
Gravava-se o disco original (máster), a partir do qual eram confeccionadas as cópias que seriam lançadas e oferecidas ao mercado consumidor. Assim se dava a publicação, forma pela qual "a obra é retirada do âmbito pessoal do seu criador, para ser levada ao conhecimento da coletividade, na sua forma definitiva"103.

As questões jurídicas sob o objeto da publicação eram, na sua maioria, de natureza contratual, oriundas da insatisfação de alguma das partes quanto à sua execução. $\mathrm{O}$ mais comum era que o compositor ficasse descontente com a escolha ou performance dos artistas indicados pelo produtor musical ou que o intérprete ficasse insatisfeito com a infraestrutura fornecida para a gravação e com sua qualidade final ${ }^{104}$. Ocorrência mais grave, entretanto, era a publicação indevida de obras musicais, que infringia tanto o direito patrimonial do autor quanto o seu direito moral, garantido pela Convenção de Berna, da qual o Brasil era signatário. Tal infração era de fácil percepção e combate, uma vez que, à época, via de regra se dava geograficamente próxima ao autor.

Uma vez gravadas as músicas e lançado o disco, eram feitas as cópias e então se iniciava a comercialização (hoje denominada distribuição) dos exemplares, geralmente prevista no mesmo instrumento contratual por meio do qual foi autorizada a publicação. O consumidor final adquiria seu exemplar físico em lojas especializadas no ramo musical, que já vendiam partituras e instrumentos musicais.

Nessa etapa da comercialização, as questões que se apresentavam eram, de forma geral, de natureza contratual, pautadas na desconfiança do compositor quanto ao número real de discos postos no mercado, algo que, aliás, até os dias de hoje desperta protestos de intérpretes e compositores.

No exterior, especialmente na Europa e nos Estados Unidos, a indústria fonográfica encontrava-se mais evoluída que no Brasil e as leis já dispunham sobre a questão específica da fixação e da comercialização musical. Era, entretanto, dos Estados Unidos que vinham os modelos contratuais a serem aqui utilizados, elaborados com base e por conta de um

\footnotetext{
103 CHAVES, Proteção internacional..., p.151.

104 Com a ressalva de que os intérpretes não possuíam, então, reconhecidos quaisquer direitos conexos ao autoral.
} 
sistema jurídico distinto (Common Law). Diante dessa imprevisão legal em nosso país ${ }^{105}$ e servindo-se do princípio da autonomia privada, parte das gravadoras aproveitava para firmar, com o compositor, contrato no qual estava prevista a remuneração com base em número de cópias vendidas, de modo que faziam repartir os riscos do empreendimento ${ }^{106}$.

Já as questões referentes à comunicação ao público despertavam muita atenção nos sujeitos da música, sendo que execuções e interpretações indevidas tiradas ao vivo preocupavam especialmente os compositores, que já tinham a proteção normativa desde a Lei n. ${ }^{\circ} 496$ de $1898^{107}$, que foi repetida no Código Civil de $1916^{108}$ e no Decreto n. ${ }^{\circ} 4.790 / 24109$.

Entretanto, dúvidas foram geradas a partir do questionamento acerca da abrangência de tal proteção: com o novel uso do gramofone, os autores-compositores não teriam mais qualquer controle do momento e local em que seriam executadas suas criações, se tais execuções se dariam sob remuneração direta ou indireta e, em caso positivo, sob que parâmetros seriam feitas as retribuições autorais.

Para complicar tudo, da leitura do artigo 657 do Código Civil de 1916 entendia-se que, uma vez publicada e exposta a obra, o autor tacitamente anuía pela sua representação

105 É a crítica de Fabio Maria De Mattia, para quem "a extrema generalidade e liberalidade testemunhadas pelo Estado favorecem a eclosão de certas limitações de fato. É assim que se verifica que a organização atual da economia e as práticas comerciais excluem, numa larga medida, a determinação individual do conteúdo do contrato. Os contratos-tipo submeteram certos setores da produção intelectual. A edição disto fornece um exemplo eloqüente pelo menos se nos ativermos à prática de certos editores importantes. O economicamente forte pode, quase sempre, impor seu ponto de vista ao economicamente fraco. É um fato que não se pode deixar de deplorar. Desejar-se-ia aboli-lo em qualquer que fosse a medida possível" (DE MATTIA, Fabio Maria. O autor e o editor na obra gráfica: direitos e deveres. São Paulo: Saraiva, 1975. p.20).

106 "O contrato de edição em que os lucros líquidos têm de ser divididos é o contrato múltiplo, - há o contrato de edição e o de sociedade, porque só se atribuiu quota do exercício do direito de edição; ou é negócio jurídico parciário. Não há solução a priori." (PONTES DE MIRANDA, Tratado de direito privado, Tomo XLIV, p.325).

107 Lei n. ${ }^{\circ}$ 496/1898: "Art. 15. Toda execução ou representação publica total ou parcial de uma obra musical não póde ter logar sem consentimento do autor, quer ella seja gratuita, quer tenha um fim de beneficencia ou exploração. Todavia, si ella for publicada e posta á venda, considera-se que o autor consente na sua execução em todo o logar onde não se exija retribuição alguma".

108 Lei n. ${ }^{\circ}$ 3.071/1916: "Art. 657. Publicada e exposta à venda uma obra teatral ou musical, entende-se anuir o autor a que se represente, ou execute, onde quer que a sua audição não for retribuída".

109 Dec. n. ${ }^{\circ}$ 4.790/1924: "Art. 2. ${ }^{\circ}$ Nenhuma composição musical, tragedia, drama, comedia ou qualquer outra producção, seja qual fôr a sua denominação, poderá ser executada ou representada em theatros ou espectaculos publicos, para os quaes se pague entrada, sem autorização, para cada vez, do seu autor, representante, ou pessôa legitimamente subrogada nos direitos daquelle". 
"onde quer que a sua audição não for retribuída", portanto isentava o utilizador do pagamento de contraprestação autoral quando não houvesse cobrança direta de ingresso. Nesse caso, se um café ou casa noturna utilizasse um gramofone, não teria que pagar ao compositor nem a ninguém (salvo o preço do disco) qualquer espécie de contraprestação.

Essa mudança, do "natural" representado pela execução ao vivo, ao "artificial", representado pela execução mecânica, é alvo de críticas por parte dos autores estadunidenses David Kusek e Gerd Leonhard, os quais mencionam que a execução musical baseada em fonogramas "mudou para sempre o conceito de música de uma experiência dinâmica e interativa para um produto fixo"110.

Com efeito, de interpretação com caráter humano, realista, contendo erros e acertos provenientes de uma execução ao vivo, caracterizada pela prestação de serviços diretamente ofertada pelos músicos e, indiretamente, pelo compositor, a música passou a ser mecânica, perfeita, bem acabada, uma vez que as tentativas de gravação eram sucessivamente repetidas até que ficassem a contento. Adquiriu, assim, a música, pelo seu novo suporte físico, o caráter de produto ${ }^{111}$. E esse é um aspecto de relevância no presente estudo.

O público, acostumado a desembolsar por uma apresentação ao vivo, serviço executado em teatros, cafés e demais lugares destinados a tal, passou a desembolsar pela aquisição de um produto, meio físico representado por um disco de goma-laca, que podia ser escutado tantas vezes quanto desejasse o usuário, em qualquer hora do dia ou da noite.

Foi quando surgiu a grande dúvida nos titulares de direito de autor, e que bem resume a primeira crise constatada do direito autoral e música: como controlar a utilização do gramofone, o qual possibilitou que as pessoas passassem a escutar músicas sem

110 Cf David Kusek e Gerd Leonhard, para os quais "the big deal was that the gramophone allowed people to listen to music without having to actually be at the performance. It forever changed the concept of music from a dynamic and interactive entertainment experience to a fixed product" (KUSEK, David; LEONHARD, Gerd. The future of music: manifesto for the digital music revolution. Boston: Berklee Press, 2005. p.12). [grifo nosso].

111 David Kusek e Gerd Leonhard acentuam o caráter experimental e dinâmico que a música possuía antes da criação do gramofone (e, conseqüentemente, da indústria fonográfica): "prior to the nineteenth century, music wasn't played the exact same way more than once, since it was impossible to reproduce the exact circumstances of a performance. The instruments and orchestration would chang, as would the performers, their moods, audiences, and performance environments. Songs were performed as well as they could be in that moment, and composers worked hard to create a continuous flow of fresh music for fairs, operas, concerts, trade show, theaters, and so forth. The composers of the time also liberally borrowed material from one another, often adapting, updating, and improving the songs for the players and performances at hand" (KUSEK e LEONHARD, The future of music..., p.12). 
necessariamente estarem presentes à audição? Como remunerar os compositores e intérpretes, diretamente atingidos por essa inovação técnica?

Tal situação era confortável à indústria fonográfica, já que o que lhe interessava era vender os discos e os aparelhos leitores. E isso efetivamente estava a ocorrer. Não havia contrafação ${ }^{112}$ de discos, até mesmo porque quem pretendesse fazê-la deveria adquirir os caros equipamentos para tal, e, conseqüentemente, quem os tinha eram somente as representantes da indústria fonográfica, as quais, por sua vez, preferiam produzir os discos com as músicas dos compositores e intérpretes do seu próprio elenco, com os quais mantinham contratos de exclusividade. Assim, não faria sentido destinar somas vultosas para reproduzir músicas alheias.

Tampouco interessava às gravadoras, nesse início, o local em que eram feitas as execuções das músicas gravadas, se nos recintos privados ou públicos, contanto que vendessem cada vez maior número de produtos (gramofones e discos).

Em vista da posição contratual privilegiada que as gravadoras detinham em relação ao compositor, a este era transferido o ônus de investigar quanto às execuções musicais de suas obras, se remuneradas ou não, e, caso positivo, tentar cobrar os respectivos direitos, o que lhes era inviável pelo alto custo judicial e dificuldade de comprovação.

Em resumo, a primeira crise do direito de autor na música foi causada pela introdução da tecnologia da fixação de sons em meio físico para posterior audição e consistiu, principalmente: i) no início de uma forte indústria fonográfica, que nas décadas seguintes passou a decidir o que seria escutado pelo público; (ii) na constatação da mudança da caracterização da música de serviço para produto, com as implicações sociais e jurídicas decorrentes; e (iii) no estabelecimento de dúvida quanto ao mecanismo de controle da execução musical e respectiva remuneração aos compositores.

\subsubsection{A Segunda Crise: A Radiodifusão}

Ao final do século XIX, comprovando a teoria desenvolvida pelo físico alemão Heinrich Hertz, o italiano Guglielmo Marconi patenteou o primeiro sistema de radiodifusão, que

112 LDA, "Art. 5. Para os efeitos desta Lei, considera-se: VII - contrafação - a reprodução não autorizada." 
evoluiu e se tornou popular a partir da década de $1920^{113}$. Com a introdução de tal tecnologia, mais pessoas passaram a ter contato com as obras musicais, já que as performances radiofônicas se davam por meio de fonogramas executados por gramofone ou ao vivo, a partir dos estúdios da emissora de rádio, e se propagavam via ondas hertzianas a um número indefinido de pessoas que dispusessem de aparelhos receptores, nos mais variados lugares, inclusive em países diferentes do local de emissão ou retransmissão dos sinais radiofônicos.

Foi imenso o impacto causado pela radiodifusão na sociedade. As possibilidades de utilização do novo meio eram assustadoras e abrangiam aspectos culturais, educacionais, políticos e religiosos, além de econômicos.

Para Antonio Chaves:

\begin{abstract}
A radiodifusão desenvolve junto a cada indivíduo, no mundo inteiro, uma missão de distração, de instrução e de educação cuja importância não pode ser exagerada. Não sòmente aumenta extraordinàriamente a divulgação das obras intelectuais, anteriormente feita apenas através de livros, publicações e conferências, como o faz numa instantaneidade análoga à de um jato de luz. (...) é indiscutível que a propagação, elemento e condição da produção intelectual, tornou-se facílima e prática, dando ao pensamento uma importância e um poderio qual nunca registrou em qualquer época da história. ${ }^{114}$
\end{abstract}

A radiodifusão, em pouquíssimo tempo, foi alçada ao status estratégico pelos governos dos países e, na maioria deles, passou a ser alvo de regulação e objeto de concessão pelo Estado, constituindo serviço público. Os empreendedores que desejassem ingressar em tal ramo, além do vultoso investimento em equipamentos, teriam de estar preparados para atender às finalidades educacionais que as leis nacionais passaram a determinar ${ }^{115}$, o que também representava custos.

113 "Referem os historiadores que, embora a radiodifusão tenha tido início pràticamente em 1919, a primeira difusão de manifestações do pensamento humano por meio das ondas elétricas e de sinais convencionais se verificou quando Guilherme Marconi, no ano de 1896, levantou a primeira antena emissora." (CHAVES, Proteção internacional..., p.96).

114 CHAVES, Proteção internacional..., p.100-101. Com efeito, tal constatação, tomada décadas atrás, pode muito bem retratar a realidade atual, da (r)evolução causada pela internet e demonstra como a história acaba por se repetir sob outras roupagens, fato perceptível durante toda a história recente da música e suas implicações perante o direito de autor.

115 A reação natural daqueles que detêm o poder, quer seja político, quer seja econômico, é a rejeição da mudança e a manutenção do status quo, mediante a adoção de postura conservadora. Não foi diferente com a radiodifusão. Os governos, ao não compreenderem direito a abrangência e o poder que tal nova tecnologia trazia, preferiram, ao mesmo tempo em que controlavam a concessão das freqüências, instituir normas restritivas que vinculavam a radiodifusão a um fim educacional. Adolf Hitler, aliás, soube muito bem utilizar o rádio para disseminar a "educação" que lhe parecia mais conveniente e assim doutrinar não somente seus concidadãos como diversos cidadãos estrangeiros, por toda a Europa. 
Corriam riscos, ainda, os donos de rádio, pela sujeição às justas reclamações não somente dos compositores, mas também por parte da indústria fonográfica. Os primeiros recorriam ao Poder Judiciário contra a exploração não-autorizada de suas obras, aonde vinham obtendo indenizações - em vista da interpretação extensiva que o julgador dava ao direito de autor vigente em relação à novel tecnologia. A segunda, do desinteresse inicial pela comunicação ao público, passou a se preocupar com a utilização não-remunerada de suas gravações pelas rádios, através da radiodifusão ${ }^{116}$.

Então, se num primeiro momento, não muito atrás, os principais problemas enfrentados pelos compositores eram relacionados à contrafação das partituras musicais e à comunicação ao público, normalmente com efeitos mais facilmente rastreáveis, agora se deparavam com a desconhecida situação proporcionada pelos avanços tecnológicos ${ }^{117}$. O fato é que imediatamente após verem a criação de uma indústria fonográfica baseada na gravação em meios físicos (discos), que ainda não havia sido devidamente assimilada, foram surpreendidos com a transmissão e propagação de suas obras, com as vantagens e o ônus que isso lhes proporcionava.

A vantagem mais evidente que a radiodifusão proporcionava ao compositor era o aumento de possibilidade de seu reconhecimento e apreço, pelo público em geral. Ainda, o número de pessoas que passariam a ter acesso à sua criação seria ilimitado, o que traria benefícios financeiros tanto diretos quanto indiretos. O ônus mais patente é que muitos passaram a ser contratualmente obrigados a simplesmente ceder os respectivos direitos de execução radiofônica da obra à gravadora, a exemplo do que já muitas vezes eram forçados a fazer em relação aos demais conteúdos patrimoniais correspondentes à fixação em fonogramas ${ }^{118}$.

116 Pontes de Miranda aponta confusão doutrinária que havia em relação à execução musical e a radiodifusão de música: "É preciso insistirmos em que a radiodifusão da música não é execução. Execução já houve, ou está havendo; a radiodifusão é plus e posterius. Tão-pouco é representação a televisão. Representação já houve, ou está havendo; a radiodifusão é plus e posterius. Ali, há nova reprodução acústica; aqui, nova reprodução ótica." (PONTES DE MIRANDA, Tratado de direito privado, Tomo XVI, p.151).

117 Diversas dúvidas, entretanto, passaram a afligir os autores: as normas existentes poderiam ter interpretação extensiva ou seria necessária a edição de leis específicas?; como controlar as emissões de suas músicas, considerando que, num primeiro momento, as interpretações eram feitas ao vivo, entretanto em localidades diferentes, até em território estrangeiro?; tais emissões poderiam ser feitas sem autorização prévia, mas legitimadas por contraprestação financeira, sob forma de licenciamento compulsório?

118 E isso ocorria porque as gravadoras eram cônscias da necessidade de obter diferentes autorizações para diferentes utilizações. Para Pontes de Miranda; "Cada nôvo modo de utilização como que debulha o direito autoral de exploração, em cujo conteúdo há feixe de poderes" e "a outorga do poder de fazer 
Assim, a indústria fonográfica assumiu, mais uma vez pela via contratual, a posição jurídica do autor-compositor, sujeito protagonista do direito de autor, para, em nome dele, ou em seu próprio nome quando cessionária dos direitos patrimoniais, ou representada por sociedade de defesa dos direitos autorais ${ }^{119}$, pleitear pagamentos referentes à execução pelas rádios. Esse relacionamento se construiu e alternou, ao longo dos anos, ciclos de amor e ódio, já que, para que uma música viesse a se tornar um sucesso e assim impulsionar a venda de discos, a rádio constituía um meio importante, mas, em contrapartida, justamente pelo fato de a rádio transmitir as músicas, teoricamente menor quantidade de exemplares de discos seria vendida ${ }^{120}$.

A esse respeito, Pedro Vicente Bobbio já informava que:

\begin{abstract}
Quando o radio surgiu, os fabricantes julgaram interessante e proveitosa a publicidade que as emissoras faziam às obras gravadas em discos. Mas a multiplicação das estações emissoras e a generalização dos aparelhos receptores introduziram, no público, o hábito de procurar nas audições radiofônicas a satisfação das suas preferencias musicais, sem a necessidade de gastar dinheiro na compra dos discos. A venda desses caiu verticalmente. E os fabricantes tornaram-se ferrenhos adversários da radiodifusão. ${ }^{121}$
\end{abstract}

discos não importa em outorga do poder de dar o disco à irradiação (outra exploração); nem a outorga do poder de fazer o disco para irradiar atribui o de fazer discos para vender." (PONTES DE MIRANDA, Tratado de direito privado, Tomo XVI, p.159).

119 Cf. Dec. 5.492/28: "Art. 28. As sociedades nacionaes ou estrangeiras, legalmente constituidas para a defesa de direitos autoraes, reputar-se-hão mandatarias de seus associados, para todos os fins de direito, pelo simples acto de filiação ás mesmas, salvo clausula expressa em contrario". Pontes de Miranda apresenta severíssima crítica à possibilidade de cobrança de direitos autorais pelos produtores musicais, por intermédio de sociedade de defesa de direitos autorais: "Se a sociedade que se diz para proteção dos direitos autorais contém sócios que são editôres ou empresas de execução (teatros, clubes, casa de diversões, sociedades de execução musical), dentro dela mesma está colisão de interesses, que a torna essencialmente inadequada à finalidade que a lei provê para a representação dos autores." (PONTES DE MIRANDA, Tratado de direito privado, Tomo XLIV, p.352).

120 Para Stan Liebowitz, a transmissão por radiodifusão não auxilia o mercado fonográfico: "I have examined two episodes in which the impact of radio should be relatively easy to observe. The evidence from this empirical examination indicates that, contrary to common beliefs, radio broadcast does not enhance the market for sound recordings." (LIEBOWITZ, Stan J. The Elusive Symbiosis: The Impact of Radio on the Record Industry. School Of Management. Dallas: University of Texas. Mar. 2004. p.41).

121 BOBBIO, O direito de autor..., p.99-100. No mesmo sentido, Antonio Chaves afirmava que: "a princípio, quando a radiodifusão se encontrava ainda em período experimental, o interêsse geral estava concentrado na nova conquista técnica, da qual todos percebiam a extraordinária importância. Nessa ocasião, a radiodifusão em geral valia-se de trabalhos que não gozavam da proteção do direito de autor. Somente mais tarde, com a divulgação da nova técnica, lançou-se a radiodifusão à procura de outros trabalhos, surgindo então a questão de saber se o direito de autor proibia as radiodifusões não autorizadas. Relutaram a princípio as radiodifusoras em pagar retribuições aos autores, alegando, como justificativas ainda hoje invocadas, as grandes despesas das instalações, equipamentos e manutenção, e os benefícios que a radiodifusão traria aos autores independentemente mesmo de qualquer remuneração direta, pela extraordinária divulgação de suas obras" (CHAVES, Antonio. Proteção internacional do direito autoral de radiodifusão. São Paulo: Marajó, s/d. p.161). 
Com efeito, o rádio proporcionava maior qualidade sonora e comodidade aos usuários, uma vez que, ao contrário do que ocorria com os discos, não se precisava trocar de lado a cada quatro minutos, e justamente por isso deixavam de comprar os discos, preferindo escutá-los pelo rádio ${ }^{122}$.

Entretanto, todo avanço tecnológico traz junto incertezas. Com a radiodifusão não foi diferente. Desconhecida situação passou a compor a esfera dos atores da cena musical. Ao mesmo tempo em que formidáveis perspectivas se abriam pela possibilidade em dar conhecimento geral e virtualmente ilimitado às obras musicais e, conseqüentemente, fazer com que os autores ficassem cada vez mais conhecidos e financeiramente recompensados, passaram a ser cada vez mais freqüentes as explorações, tidas como indevidas, das obras musicais.

Era a segunda grande crise do direito de autor no âmbito da música que, a exemplo da primeira, foi motivada pela novidade tecnológica e pela ausência de previsão normativa. Acresça-se o fato de que ambas as crises ocorreram de forma quase simultânea.

Do mesmo modo que com os investidores da indústria fonográfica na primeira crise do direito de autor, os proprietários de empresas de radiodifusão, sentindo-se ameaçados pelos produtores musicais e pelas outras rádios que praticavam retransmissões não-autorizadas, perceberam a necessidade da constituição de garantias normativas, o que originou o entendimento de que deveriam gozar o que atualmente são conhecidos como direitos conexos ao direito de autor, pelo que passaram a pressionar as autoridades.

Pedro Cordeiro, ao tratar do tema, constatou que "a ubiquidade da radiofonia era incontrolável e, como sempre acontece, foi o Direito que teve de se adaptar à realidade e não o inverso" 123 .

122 "Listening to radio or sound recordings could both be done at home. The acoustic quality of radio was often better than what was available with early recordings. Sound recordings in the 1920s and 1930s tended to allow only four minutes or so of play on a side before another record would have to be loaded onto the platter, making them fairly inconvenient for listening to music at long stretches. It is not surprising, therefore, that there was a reasonable substitution effect that hurt the market for records." (LIEBOWITZ, The Elusive Symbiosis..., p.25).

123 CORDEIRO, Pedro João Fialho da Costa. Direito de autor e radiodifusão: um estudo sobre o direito de radiodifusão desde os primórdios até à tecnologia digital. Coimbra: Almedina, 2004. p.23. 
Em 1928, teve lugar na Itália a Conferência Diplomática de Roma, que objetivava a revisão da Convenção de Berna. Ao lado do direito moral, a radiodifusão foi o tema principal $^{124}$, pois a crise estava no auge.

Informa o português Pedro Cordeiro ${ }^{125}$ que enquanto "vários Estados pretendiam que o interesse público estivesse contemplado através da possibilidade dos países estabelecerem licenças não-voluntárias", outros defendiam o contrário. Prevaleceu o meiotermo, que refletiu no texto do artigo 11-bis da Convenção de Berna ${ }^{126}$ :

1 - Os autores das obras literárias e artísticas gozam do direito exclusivo de autorizar a comunicação das suas obras ao público pela radiodifusão.

2 - Compete às leis nacionais dos países da União regular as condições do exercício dos direitos referidos na alínea precedente, mas essas condições terão um efeito estritamente limitado ao país que as tiver estabelecido. Elas não poderão em nenhum caso atingir o direito moral do autor, nem o direito que pertence ao autor de obter uma remuneração eqüitativa fixada, na falta de acordo amigável, pela autoridade competente.

À época da Conferência de Roma tudo era ainda muito recente, de modo que se preferiu postergar as discussões referentes à radiodifusão para a próxima revisão, mas já com o reconhecimento explícito do direito exclusivo do autor em autorizar a comunicação das obras pela via da nova tecnologia.

Vinte anos depois, em 1948, Bruxelas foi sede da Conferência de revisão da Convenção de Berna, onde se estatuiu o texto do artigo 11-bis hoje vigente ${ }^{127}$, sobre

124 Os intérpretes, que atuavam a descoberto de qualquer direito, buscaram, nessa Revisão de Roma, sua inserção no quadro do direito autoral, sob a égide da Convenção de Berna. Não obtiveram êxito.

125 CORDEIRO, Direito de autor..., p.37.

126 Tal texto é aquele da Conferência de Roma e foi alterado em Conferências posteriores. Foi proposto pela França e seu teor em francês é: "Art. 11-bis:(1) Les auteurs d'oeuvres littéraires et artistiques jouissent du droit exclusif d'autoriser la communication de leurs oeuvres au public par la radiodiffusion. (2) Il appartient aux législations nationales des Pays de l'Union de régler les conditions d'exercice du droit visé à l'alinéa précédent, mais ces conditions n'auront qu'un effet strictement limité au pays qui les aurait établies. Elles ne pourront en aucun cas porter atteinte ni au droit moral de l'auteur, ni au droit qui appartient à l'auteur d'obtenir une rémunération équitable fixée, à défaut d'accord amiable, par l'autorité compétente". No Brasil, a revisão da Conferência de Roma na Convenção de Berna foi internalizada pelo Decreto n. ${ }^{\circ} 23.270$, de 24 de outubro de 1933.

127 "Artigo 11-bis. 1) Os autores de obras literárias e artísticas gozam do direito exclusivo de autorizar: $1 .^{\circ}$ A radiodifusão das suas obras ou a comunicação pública dessas obras por qualquer outro meio que sirva à difusão sem fio dos sinais, sons ou imagens; 2. ${ }^{\circ}$ Qualquer comunicação pública, quer por fio, quer sem fio, da obra radiodifundida, quando essa comunicação seja feita por outro organismo que não o de origem; $3 .^{\circ}$ A comunicação pública, por alto-falante ou por qualquer outro instrumento análogo transmissor de sinais, sons ou imagens, da obra radiodifundida. 
radiodifusão, que trata da comunicação ao público de obras protegidas pelo direito de autor de maneira ampla e abrangente, inclusive às novas tecnologias.

Enfim, as questões que nessa etapa mais afligiam os sujeitos envolvidos na radiodifusão eram referentes à comunicação ao público, até mesmo porque o conceito de público havia sofrido mudanças desde a (recente) primeira crise do direito de autor na esfera musical. Com o alcance que a radiodifusão proporciona, o público passou a ser indefinido e ilimitado. É o que constata Pedro Cordeiro:

\begin{abstract}
O que fica dito ganha, ainda, maior expressão se atendermos a que o próprio conceito de público é em Direito de Autor evolutivo - adaptando-se às circunstâncias e desenvolvimento técnicos. De facto, a primeira noção de público referia-se à reunião de um grande número de pessoas em espaços onde se realizavam espetáculos. Tinham-se em vista, sobretudo, representações cénicas e execuções musicais. A primeira cambiante deu-se precisamente com a radiodifusão e no sentido em que expusemos - o público passa a ser entendido como o conjunto indeterminado e indiscriminado de potenciais receptores independentemente do local onde se encontrem. ${ }^{128}$
\end{abstract}

Com o advento da radiodifusão, foram acrescentados à esfera do direito de autor na obra musical primígenos dos conceitos atuais de transmissão ${ }^{129}$, retransmissão ${ }^{130}$ e radiodifusão ${ }^{131}$.

2) Compete às legislações dos países da União regular as condições de exercício dos direitos referidos na alínea 1) supra, mas essas condições terão um efeito estritamente limitado ao país que as tiver estabelecido. Elas não poderão em nenhum caso atingir o direito moral do autor, nem o direito que pertence ao autor de obter uma remuneração equitativa fixada, na falta de acordo amigável, pela autoridade competente.

3) Salvo estipulação em contrário, uma autorização concedida em conformidade com a alínea 1) do presente artigo não implica a autorização de gravar, por meio de instrumentos permitindo a fixação dos sons e imagens, a obra radiodifundida. Fica, todavia, reservado às legislações dos países da União o regime das gravações efémeras efectuadas por um organismo de radiodifusão pelos seus próprios meios e para as suas emissões. Essas legislações poderão autorizar a conservação dessas gravações nos arquivos oficiais por motivo do seu carácter excepcional de documentação". Nas Conferências de Estocolmo (1967) e de Paris (1971) foram diversas as propostas para alteração do artigo 11-bis, o que acabou não ocorrendo, em vista da falta de consenso para sua alteração".

128 CORDEIRO, Direito de autor..., p.58.

129 LDA: "Art. 5. ${ }^{\circ}$ Para os efeitos desta Lei, considera-se: II - transmissão ou emissão - a difusão de sons ou de sons e imagens, por meio de ondas radioelétricas; sinais de satélite; fio, cabo ou outro condutor; meios óticos ou qualquer outro processo eletromagnético."

130 LDA: "Art. 5. ${ }^{\circ}$ Para os efeitos desta Lei, considera-se: III - retransmissão - a emissão simultânea da transmissão de uma empresa por outra".

131 LDA: "Art. 5. ${ }^{\circ}$ Para os efeitos desta Lei, considera-se: XII - radiodifusão - a transmissão sem fio, inclusive por satélites, de sons ou imagens e sons ou das representações desses, para recepção ao público e a transmissão de sinais codificados, quando os meios de decodificação sejam oferecidos ao público pelo organismo de radiodifusão ou com seu consentimento". 
Cabe ressaltar que, em 1934, foi desenvolvida a tecnologia que originou o gravador de rolo, pela qual se fixavam sons em rolos de fitas magnéticas, o que era feito em alta qualidade. As emissoras de rádio passaram a utilizar tais equipamentos para a gravação de suas transmissões, armazenamento em arquivos e posterior retransmissão.

É digno de nota, ainda, o fato de que paralelamente às duas primeiras crises do direito de autor na música surgiram o cinema falado e conceito de obra audiovisual 132 .

132 Em paralelo à criação e desenvolvimento dos meios de fixação de sons, os irmãos Lumière inventaram o cinematógrafo, em 1895, aperfeiçoando o cinetoscópio de Thomas Edison. O primeiro filme a ser publicamente exibido foi "L'Arrivée d'un Train à La Ciotat".

No início, as apresentações dos curtos filmes eram realizadas sem qualquer espécie de som, mas na medida em que a tecnologia foi evoluindo percebeu-se a possibilidade da introdução de fundo sonoro para realçar o filme e assim aprimorar a experiência dos espectadores. Passou-se a contratar músicos, especialmente pianistas, que executavam ao vivo determinada seleção musical, de acordo com as imagens exibidas, na chamada "sincronia", que deu remota origem ao chamado "direito de sincronização", exposto no art. 29, V da vigente Lei n. ${ }^{\circ}$ 9610/98, que é, nas palavras do estadunidense Steve Gordon "o direito de gravar uma composição musical em sincronizada conexão com os quadros ou imagens em uma produção audiovisual, tal como um filme, programa televisivo, comercial televisivo, produção de vídeo ou sítio internet" (GORDON, Steve. The future of the music business: how to succeed with the new digital techonologies. São Francisco: Backbeat Books, 2005. p.7).

Em 1927 o estúdio Warner lançou "The Jazz Singer", o qual continha algumas músicas e diálogos, intercalados com momentos sem qualquer som. Em 1928, The Lights of New York", também do estúdio Warner, foi o primeiro filme a apresentar total sincronização de sons e vídeo. Em 1929 a tecnologia foi aprimorada, o que possibilitou a inserção de sons na produção cinematográfica e, com isso, a verdadeira instauração do "cinema falado" em Hollywood e o conceito de obra audiovisual. A indústria cinematográfica evoluiu e causou profundas mudanças sociais. São diversas as tecnologias utilizadas, com evolução em ritmo rápido e desenvolvimento de novas experiências, a exemplo dos filmes em terceira dimensão.

Para M. William Krasilovzky e Sydney Shemel, "a música é muito importante para a indústria cinematográfica e, reciprocamente, filmes são de primordial importância para a indústria fonográfica. Uma considerável quantidade de música aparece em um filme qualquer. Os filmes geralmente atingem vasta exposição para o público e há exposição compatível da música no filme" (KRASILOVSKY, M. William; SHEMEL, Sidney. This business of music: the definitive guide to the music industry. 9.ed. Nova Iorque: Watson-Guptill Publications, 2003. p.226).

A exemplo da indústria fonográfica, a indústria cinematográfica passa, atualmente, por um momento de intensa preocupação em vista da indefinição quanto a seu futuro. Culpa a disseminação ilícita de conteúdos pela internet por perdas que considera gigantescas. Conduz, entretanto, ao mesmo questionamento de fundo deste trabalho que versa sobre direito de autor sob enfoque musical: estará tal indústria preparada para as amplas mudanças que o digital trouxe ou buscará manter o estado anterior, mediante interpretações rigorosas das leis civis e penais que ajudou a criar?

Outrossim, a introdução do cinema e do direito de sincronização não chegaram a representar uma crise no direito de autor no âmbito musical, mas sim uma oportunidade preciosa de se fazer com que determinadas músicas caíssem no gosto popular e, conseqüentemente, fossem aumentadas as vendas de discos, do mesmo modo que as músicas constituíram fator fundamental para a indústria cinematográfica Diante disso, constata-se que o cinema foi - e é - muito valioso para a música. Entretanto, em que pese tal importante inter-relação, foge do escopo do presente estudo adentrar em pormenores em relação à obra audiovisual. Existem, também, relevantes questões referentes à execução de obras musicais sincronizadas em filmes e sua cobrança por associações de cobrança de execução pública de obras musicais, lítero-musicais e fonogramas (no Brasil o ECAD), assim como os mesmos problemas em relação ao que se convencionou chamar de "pirataria" (é exemplar o famoso caso, no final de 2007, do "lançamento" do filme "Tropa de Elite" pelos vendedores ambulantes, meses antes do lançamento oficial). As conclusões deste estudo em grande parte poderão ser aplicadas à industria dos filmes. 
Em resumo, a segunda crise do direito de autor na música foi causada pelo advento da radiodifusão, tendo ocorrido em tempo quase simultâneo à primeira crise, da fixação de sons em meio físico, e consistiu: i) no início de um forte segmento de radiodifusão; ii) na incerteza jurídica que passou a afligir, num primeiro momento, os compositores e, num segundo momento, os produtores musicais, no que diz respeito à utilização de fonogramas pelas emissoras e respectivas retribuições autorais; iii) no desenvolvimento dos que viriam a ser conhecidos como direitos conexos aos autorais, pela garantia legal que passaram a ter os organismos de radiodifusão.

\subsection{O PÓS-GUERRA: O "OLIMPO" DA INDÚSTRIA FONOGRÁFICA}

Na Europa e nos Estados Unidos, a Segunda Guerra Mundial forçou as indústrias a modificarem suas linhas de produção para a fabricação de equipamentos militares, assim como estagnou o mercado de bens de consumo que não fossem essenciais.

Conseqüência natural é que, imediatamente após o cessar-fogo, tudo aquilo que estava represado, latente, emergisse com força total. E com a música não foi diferente. A pesquisa, direcionada em tempos de guerra para fins militares, proporcionou avanços que passaram a ser utilizados em tempos de paz e voltou a ser praticada pelos mais diversos setores, inclusive o musical.

Assim, antes mesmo do final da década de 1940 foi desenvolvida a tecnologia do microssulco, com a instituição do disco de vinil (o chamado Long Play - LP) no lugar do antigo material goma-laca, o que possibilitou a obtenção de melhor qualidade sonora e, principalmente, maior capacidade de tempo de gravação, que praticamente decuplicou.

A última Conferência de Revisão da Convenção de Berna havia sido em 1928, em Roma, quando muitas questões ficaram em aberto em virtude dos avanços tecnológicos e da ausência de consenso em pontos de extrema importância (vide o já mencionado exemplo da radiodifusão, tema sobre o qual as partes decidiram postergar qualquer decisão de maior relevância).

Imediatamente após a mencionada conferência, foram iniciados estudos preparativos para a próxima, o que tomou boa parte da década de 1930, mas que tiveram de ser suspensos em virtude do conflito mundial. Em 1948, três anos após o cessar-fogo, teve lugar a Conferência de Bruxelas, a qual, no que concerne à questão musical, teve o condão de introduzir as bases do moderno direito de autor, com previsões amplas sobre a recepção automática de avanços tecnológicos. 
A Segunda Grande Guerra deixou um vácuo a ser preenchido nos espíritos das pessoas, que culminou no fortalecimento de formas de entretenimento durante a década de 1950, quando a indústria fonográfica percebeu uma excelente oportunidade para lançar cantores-ídolos que movimentassem as multidões, que mexessem com o imaginário das massas. Estilos musicais que até então, sob uma análise puritana, eram tidos como profanos, a exemplo do blues e do jazz, passaram a ser valorizados e tocados nas rádios, bem como ofertados pelas gravadoras aos consumidores de discos. Nasceu o Rock'n Roll, sob a voz dos ídolos populares Elvis Presley, Jerry Lee Lewis, Johnny Cash, dentre outros que rapidamente se tornaram modelos para uma geração de jovens que cresceram sob educação restritiva e rígida, acompanhando notícias bélicas ${ }^{133}$.

A indústria fonográfica passou a faturar quantias enormes, baseada em um modelo de negócios que consistia: i) na busca de bons compositores, dos quais adquiriam os direitos e ii) na busca e contratação de bons intérpretes para as músicas, quando não era o próprio compositor que as interpretava.

Nessa fase, a radiodifusão era de extrema importância para atingir o público, já que fazia toda a diferença a quantidade de vezes que a música era tocada para que ela fosse vendida, encartada em disco com outras interpretações do(s) mesmo(s) intérprete(s).

Para o contato e desenvolvimento de relações com as rádios foram estabelecidos, nas gravadoras, os departamentos comerciais, que se encarregavam de enviar os chamados "singles" contendo aquela música, dentre outras do álbum, que certamente cairia no gosto popular e que se encarregaria de motivar o público a comprar o disco. Foi fortalecido, também, nesse momento, no Brasil, o popularmente chamado "jabaculê" ou "jabá"134, que

133 "Rock'n 'roll revitalized pop music starting with Chuck Berry and then Elvis and growing into the era of the Beatles and the Rolling Stones. During those years the music business grew approximately tenfold. The music became a more important component in our culture and our identity than ever before. The music became part of the boomer generation's identity and their vision of the world and their future." (GORDON, The future of music..., p.91).

134 Que nos Estados Unidos é chamado de payola, numa palavra criada a partir de pay (pagar) mais victrola (vitrola), ou seja, pagar para tocar a vitrola. Trata-se de algo ilegal nos Estados Unidos, mas que foi muito praticado desde a década de 1920. O chamado "jabá" é prática muito comum no Brasil, onde também recebe a denominação de "verba de divulgação" ou "acordo comercial", conforme narra a repórter Adriana Negreiros, ao entrevistar o empresário Tutinha, proprietário da Rádio Jovem Pan: "por isso é tão escandalosa a crítica mais recorrente a Tutinha: de que ele cobra jabá (presentes, dinheiro ou vantagens) para que artistas toquem em sua rádio. Ele não nega, embora não goste do termo - prefere falar que é um 'acordo comercial'. Sem constrangimento, Tutinha diz ter ganhado 1 milhão de dólares por ter lançado a cantora colombiana Shakira no Brasil. Também afirma ter conhecido vários países graças aos pacotes pagos pelas gravadoras de artistas internacionais. Nesta entrevista, ele revela candidamente seu método de escolha dos músicos que tocam na Jovem Pan: 'Recebo 30 artistas novos por dia na rádio. Seleciono dez, vou à gravadora e, para aquela que me 
para a indústria fonográfica era computado como custo de divulgação, mas que se revelou uma relação promíscua de interferência na programação das rádios, que acabavam por tocar as músicas recebendo direta ou indireta contraprestação.

Nessa época pós-guerra, os compositores cujas obras atingissem o gosto do grande público estavam sendo bem recompensados e adquiriam posição de negociação muito mais confortável do que há poucos anos antes. A competição entre as gravadoras era intensa, com vistas a contratar com aqueles que demonstravam talento e competência (note-se que não necessariamente qualidade) para promover a venda de discos.

A legislação, no aspecto formal, bem protegia o autor, ao menos aquela baseada no direito de autor latino-germânico (Brasil aí incluso), entretanto como muito se operavam as cessões de direitos patrimoniais, a proteção transmitia-se ao novo titular, usualmente as gravadoras.

A indústria fonográfica passou a ser organizada sob os preceitos empresariais, com diversos departamentos: de produção, que se encarregava da gravação, com sofisticados estúdios e equipamentos de prensagem dos discos; comercial, que efetuava as vendas e a logística de distribuição dos discos; marketing, que se encarregava da promoção dos artistas e dos discos, além de identificar as tendências para os próximos lançamentos; e jurídico, que elaborava e gerenciava os contratos que eram assinados com os compositores e intérpretes.

$\mathrm{O}$ fato é que quem quisesse desenvolver carreira musical, quer como compositor, quer como intérprete, a exemplo do que ocorria entre as décadas de 1920-40, deveria necessariamente se vincular à indústria fonográfica, em vista de que se não o fizesse simplesmente não veria a carreira prosperar, já que não havia a possibilidade de fazer gravações sem os caros

dá alguma vantagem, eu dou preferência"'. (NEGREIROS, Adriana. Tutinha. Revista Playboy, ed. 368, nov. 2005. Entrevista.). Projeto de Lei n. ${ }^{\circ} 1.048 / 2003$, de autoria do Dep. Fernando Ferro, tramita na Câmara dos Deputados, com texto que insere artigo que crimizaliza tal conduta, no Código Brasileiro de Telecomunicações: "Art. 1. ${ }^{\circ}$ Esta lei visa proibir as pessoas jurídicas autorizadas, concessionárias ou permissionárias de serviços de radiodifusão e televisão, de receber dinheiro, ou qualquer outra vantagem, direta ou indireta, de gravadora, artista ou seu empresário, promotor de concertos, ou afins, para executar ou privilegiar a execução de determinada música. Art. 2. ${ }^{\circ}$ A Lei n. ${ }^{\circ}$ 4.117, de 27 de agosto de 1962, passa a vigorar acrescida do seguinte art. 53A: 'Art. 53A. Constitui crime, punível com a pena de detenção, de 1 (um) a 2 (dois) anos, sem prejuízo das sanções de multa, suspensão ou cassação, previstas nesta lei, receber, na qualidade de proprietário, gerente, responsável, radialista ou apresentador de pessoa jurídica autorizada, concessionária ou permissionária de serviço de radiodifusão, dinheiro, ou qualquer outra vantagem, direta ou indireta, de gravadora, artista ou seu empresário, promotor de concertos, ou afins, para executar ou privilegiar a execução de determinada música.' Art. 3. ${ }^{\circ}$ Esta lei entra em vigor na data de sua publicação". Para aprofundamento no tema vide: SIDAK, J. Gregory; KRONEMYER, David E. The 'New Payola' and the American Record Industry: Transaction Costs and Precautionary Ignorance in Contracts for Illicit Services. Harvard Journal of Law and Public Policy, v.10, n.3, p.521-572, 1981 . 
equipamentos que as possibilitavam acontecer ${ }^{135}$ nem tampouco sem o acesso à radiodifusão, então meio fundamental para a divulgação do trabalho.

\subsubsection{A Instituição dos Direitos Conexos: a Convenção de Roma}

Da mesma maneira que décadas antes, e agora cada vez mais, em vista de os investimentos também serem maiores, todos os sujeitos envolvidos passaram a pressionar por maior garantia, representada por regras de abrangência internacional, ai incluídos a indústria fonográfica, os intérpretes (que se encontravam protegidos por algumas leis nacionais) e os organismos de radiodifusão. E isso finalmente ocorreu em 1961, com a "Convenção de Roma para a Proteção dos Intérpretes, Produtores e Organismos de Radiodifusão", diploma em que se dispôs sobre os parâmetros mínimos de proteção que os países contratantes deveriam prever em seus regramentos internos.

Em linhas gerais, informa a Organização Mundial da Propriedade Intelectual que os direitos assegurados nessa Convenção são os seguintes:

1) Intérpretes (atores, cantores, músicos, dançarinos e outras pessoas que interpretam obras literárias ou artísticas) são protegidos contra determinados atos sobre os quais não consentiram. Tais atos são: a transmissão e a comunicação ao público de suas performances ao vivo; a fixação de suas performances ao vivo; a reprodução de tal fixação se a fixação original foi feita sem os seus consentimentos ou se a reprodução foi feita para propósitos diferentes daqueles para os quais deram seus consentimentos.

2) Produtores de fonogramas gozam do direito de autorizar ou proibir a reprodução direta ou indireta de seus fonogramas. Fonogramas são definidos na Convenção de Roma sob o significado de qualquer fixação aural exclusiva de uma performance ou de outros sons. Quando um fonograma lançado para fins comerciais dá origem a usos secundários (tais como transmissão ou comunicação ao público sob qualquer forma), uma única e justa remuneração deve ser paga pelo usuário aos intérpretes, ou aos produtores de fonogramas, ou a ambos; os Estados contratantes são livres, entretanto, para não aplicar esta regra ou limitar sua aplicação.

3) Os organismos de radiodifusão gozam do direito de autorizar ou proibir determinados atos, a saber: a retransmissão de suas transmissões; a fixação de suas transmissões; a reprodução de tais fixações; a comunicação ao público de suas transmissões televisivas se tal comunicação é feita em locais acessíveis ao público mediante pagamento de entrada. ${ }^{136}$

135 Fato já denunciado pelos doutrinadores da época, a exemplo de Pedro Bobbio (BOBBIO, O direito de autor..., 1951).

136 Tradução livre "(1) Performers (actors, singers, musicians, dancers and other persons who perform literary or artistic works) are protected against certain acts they have not consented to. Such acts are: the broadcasting and the communication to the public of their live performance; the fixation of their live performance; the 
Deborah De Angelis bem resume o conteúdo dessa Convenção:

A Convenção de Roma tem o mérito de reservar aos titulares do direito conexo, seja a título originário (os artistas) seja a título derivado (os produtores de fonogramas e os organismos de radiodifusão), uma proteção contra as utilizações não-autorizadas, respectivamente, de suas execuções, de suas reproduções fonográficas e das fixações de suas retransmissões. ${ }^{137}$

O Brasil é signatário da Convenção de Roma desde 1961, a qual internalizou pelo Decreto n. ${ }^{\circ} 57.125$ de 19 de outubro de 1965. Em cumprimento ao mandamento da Convenção que previa sobre a instituição de leis internas nos países signatários, em 6 de abril de 1966 entrou em vigor a Lei n. ${ }^{\circ}$ 4.944, regulamentada em 1967 pelo Decreto n. ${ }^{\circ} 61.123$, no qual, conforme convinha ao regime de então, aproveitou-se para delegar ao Serviço de Censura de Diversões Públicas (SCDP) do Departamento de Polícia Federal a censura prévia das manifestações artísticas ${ }^{138}$. Infelizmente lançou-se mão da aplicação de bem-intencionada Convenção internacional para a instituição da barbárie.

reproduction of such a fixation if the original fixation was made without their consent or if the reproduction is made for purposes different from those for which they gave their consent. (2) Producers of phonograms enjoy the right to authorize or prohibit the direct or indirect reproduction of their phonograms. Phonograms are defined in the Rome Convention as meaning any exclusively aural fixation of sounds of a performance or of other sounds. When a phonogram published for commercial purposes gives rise to secondary uses (such as broadcasting or communication to the public in any form), a single equitable remuneration must be paid by the user to the performers, or to the producers of phonograms, or to both; contracting States are free, however, not to apply this rule or to limit its application. (3) Broadcasting organizations enjoy the right to authorize or prohibit certain acts, namely: the rebroadcasting of their broadcasts; the fixation of their broadcasts; the reproduction of such fixations; the communication to the public of their television broadcasts if such communication is made in places accessible to the public against payment of an entrance fee" (Disponível em: <http://www.wipo.int/treaties/en/ip/rome/summary_rome.html>. Acesso em: 11 nov. 2006).

137 "La Convenzione di Roma ha il pregio di riservare ai titolari del diritto connesso, sia a titolo originario (gli artisti) sia a titolo derivato (i produttori di fonogrammi e gli organismi di radiodiffusione), una protezione contro le utilizzazioni non autorizzate, rispettivamente, delle loro esecuzioni, delle loro riproduzioni fonografiche e delle fissazioni delle loro ritrasmissioni." (De ANGELIS, La tutela giuridica..., p.90).

138 Salta aos olhos a rigidez do regramento, que impunha severa burocracia e desestimulava a expressão artística. Estavam abrangidos por tal "Serviço", de não-saudosa memória: "art. 8. ${ }^{\circ}$ Dependem de prévia aprovação de respectivo programa pelo Serviço de Censura de Diversões Públicas (SCDP) do Departamento de Polícia Federal: I - as execuções, irradiações, bailes, funções esportistas, recreativas ou beneficentes, realizadas em teatros, cinemas, estações de rádio e televisão (com ou sem auditório), circos, parques, cassinos, bares, "boites", hotéis, restaurantes, "dancings", cabarés, cafés-concerto, sociedades recreativas ou esportistas, salões ou dependências adequadas, ou quaisquer outros estabelecimentos ou locais freqüentados pelo público; II - as representações e execuções dos quais participe ator, locutor, narrador, declamador, cantor, coreógrafo, bailarino, músico ou qualquer outra pessoa que interprete ou execute obra literária, artística ou científica; III - sempre que realizadas por processo mecânico, auditivo ou audiovisual, de qualquer tipo ou natureza: a) as representações de peças teatrais de qualquer espécie, integralmente ou em parte; b) as execuções de números de canto, música, bailados, peças declamatórias e pantomimas; c) as audições de discos fonográficos". 
A introdução da proteção aos direitos conexos aos autorais ${ }^{139}$ (droits voisins ou direitos vizinhos, em vernáculo) foi justificada pela necessidade de ampliar o intuito inicial do direito de autor denominado "continental" ou "latino-germânico", que era a proteção do indivíduo-autor, por meio de sua obra. Assim, em vista das freqüentes descobertas da humanidade foi desenvolvido mecanismo que oferecesse o alargamento da proteção autoral a determinadas categorias de agentes.

No sistema do copyright, entretanto, a construção da disciplina dos direitos conexos não foi necessária, pois o sistema jurídico da common law já abarcava em sua formulação os interesses dos sujeitos que seriam beneficiados por tais direitos ${ }^{140}$.

Nessa construção jurídica, por mais que o criador intelectual mantivesse a primazia sobre a obra autoral, autorizando ou não a outros que dela se utilizassem, foi alargada a proteção e passou-se a conceder garantias normativas próprias aos produtores, editores, intérpretes e empresas de radiodifusão.

Os direitos conexos ao direito de autor são a base do desenvolvimento e da manutenção da indústria fonográfica, e sua proteção internacional, no âmbito do direito dos tratados, teve início com a Convenção de Roma de $1961^{141}$.

139 "O fonógrafo de Thomas Alva Edison e o gramofone de Emil Berliner, o cinematógrafo dos irmãos Luis e Augusto Lumière e o rádio de Enrique Federico Hertz e de Guillermo Marconi foram, entre o fim do século XIX e o início do século XX, os pontos de partida do desenvolvimento tecnológico que deu lugar ao reconhecimento dos direitos conexos." (LIPSZYC, Derecho de autor..., p.349). No âmbito da música, os interesses dos produtores de fonogramas e dos proprietários de rádios em verem assegurados e protegidos seus direitos fizeram com que surgissem, no início do século XX, as primeiras leis internas de proteção aos direitos conexos, verdadeiro alargamento do âmbito de proteção do autor, as quais, no caso da radiodifusão, especificavam o direito da transmissão de obras autorais sob parâmetros prédefinidos de retribuição autoral.

140 Aponta Miguel Ángel Emery que o conteúdo dos direitos conexos já se encontra abarcado pelo copyright, na forma de entrepreneurial copyrights: "si bien se puede hablar de derechos de autor y derechos conexos o afines, no corresponde referirse a copyright y derechos conexos, porque este se extiende a los derechos de los intérpretes, de los productores de fonogramas y de los organismos de radiodifusión, los que juntamente com los filmes cinematográficos, las emisiones de cable y los formatos tipográficos, son conocidos como entrepeneurial copyrights, o sea, copyrights empresários" (EMERY, Propriedade intelectual, p.7). No mesmo sentido, Delia Lipszyc: "el copyright se utiliza para proteger derechos originados en actividades técnico-organizativas que no tienen naturaleza autoral" (LIPSZYC, Derecho de autor..., p.40) e Patrícia Akester que, entretanto, ressalta o fato de que "a lei americana atribui direitos civis aos artistas intérpretes ou executantes e prevê sanções criminais para a tutela dos direitos em causa". (AKESTER, O direito de autor..., p.39).

141 A Organização Mundial da Propriedade Intelectual (OMPI) administra os tratados que instituíram a obrigação das partes contratantes a inserir em seus ordenamentos jurídicos locais a proteção aos direitos conexos. São eles: Convenção de Roma, de 1961, que visa à proteção de intérpretes, produtores de fonogramas e organizações de radiodifusão; Convenção de Genebra, de 1971, que visa à proteção dos produtores de fonogramas contra duplicação não-autorizada; Convenção de Bruxelas, de 1974, referente à distribuição de programas através de sinais transmitidos por satélite; o Tratado de Copyright da OMPI, de 1996, que estende a proteção ao software e banco de dados e; o Tratado OMPI para performances e 
É importante ressaltar que os direitos conexos são dependentes do direito autoral ${ }^{142} \mathrm{e}$ seu exercício exige consonância com a proteção do autor ${ }^{143}$. Mesmo assim, notícias de exercício abusivo de tais direitos são comuns, conforme será visto adiante.

\subsubsection{A Terceira Crise: a Fita-Cassete}

Nos anos 1960, as técnicas de gravação de músicas foram aprimoradas, com a introdução das mesas de gravação multicanais, que trouxe à indústria fonográfica o aumento do número de sujeitos envolvidos no processo da gravação da obra musical, antes constituído basicamente pelos compositores, intérpretes e produtores e agora inserido o engenheiro de som, que também passou a ser figura importante no processo criativo ${ }^{144}$. Isso muito interessa ao direito de autor, já que ressalta o fato de que, a cada evolução tecnológica - e são muitas em tão pouco tempo - novos atores surgem em cena.

Nessa época, o fenômeno "The Beatles" teve o condão de aumentar a venda de discos em níveis altíssimos. Tal banda musical sempre utilizou ao máximo a proteção

fonogramas, de 1996. O Brasil, entretanto, não é parte signatária nos três últimos tratados. Percebe-se, aliás, também na OMPI, nítida divisão entre o posicionamento dos países do sistema de copyright, em especial os Estados Unidos e os países do sistema continental, liderados pela França e Itália.

142 LDA: "Art. 89. As normas relativas aos direitos de autor aplicam-se, no que couber, aos direitos dos artistas intérpretes ou executantes, dos produtores fonográficos e das empresas de radiodifusão.

Parágrafo único. A proteção desta Lei aos direitos previstos neste artigo deixa intactas e não afeta as garantias asseguradas aos autores das obras literárias, artísticas ou científicas." [grifo nosso]

143 Para Alexandre Dias Pereira, ao tratar da questão dos direitos conexos sob o prisma constitucional português: "não se afigura de todo irrazoável sustentar que os direitos conexos não serão providos da mesma dignidade constitucional que os 'direitos de autor"' e que "os direitos conexos não são destinados a proteger bens gerados no exercício da liberdade de criação cultural como as obras tuteladas pelos direitos de autor, mas antes prestações artísticas e 'prestações empresariais', como sejam, por exemplo, as dos produtores de fonogramas e de filmes e dos organismos de radiodifusão" (PEREIRA, Informática, direito..., p.167).

144 O canadense Paul Théberge traz importante perspectiva sobre tal inovação e aponta o caso de George Martin, produtor, arranjador musical e intérprete em projetos da banda The Beatles, o qual era tido por muitos como "o quinto Beatle": "With the introduction in the 1960s of multitrack recording technology and the recording practices associated with it, popular musicians began to explore the possibilities offered by the recording medium, to regard sound recording not simply as a means of reproducing music but as an integral part of music creation. In the decades that followed, several trends emerged that had significant implications for copyright law. Firstly, the use of multitrack studio fostered new forms of creative collaboration between musicians, producers and engineers. In some cases, producers became closely connected to the artists with whom they worked: for example, George Martin, in his various roles as producer, arranger and occasional performer on recording projects for The Beatles, came to be regarded by many as 'the fifth Beatle', and his contribution to the sound of their recordings has been widely recognized." (THÉBERGE, Paul. Technology, Creative Practice and Copyright. In: FRITH, Simon; MARSHALL, Lee (Orgs.). Music and Copyright. 2.ed. Edimburgo: Edinburgh University Press, 2004. p.141-142). 
concedida pelo direito autoral, organizando-se de modo a preservar suas composições e interpretações, recusando-se a autorizar utilizações de suas obras em trilhas sonoras e compilações e organizando competente estrutura de coleta de valores a título de direitos autorais patrimoniais ${ }^{145}$.

Foi a partir daí que a indústria fonográfica transformou-se de negócio milionário a negócio bilionário, influindo de forma profunda na sociedade, ao adiantar tendências de comportamento e se constituir numa verdadeira linha de produção de "estrelas" musicais, as quais eram seguidas por legião de fãs.

Se antes escutar música era um ato per se, passou a ser pano de fundo para todas as ocasiões, das mais corriqueiras até para momentos festivos e de protestos. A música passou a embalar a história e adquiriu relevante significância no cotidiano das pessoas. A enorme venda de discos era o termômetro do aquecimento do negócio da música.

A situação era muito satisfatória para a indústria fonográfica, até que, mais uma vez causada pela evolução tecnológica, sobreveio a terceira crise do direito de autor na música.

Em 1963, a empresa holandesa Philips ${ }^{146}$, conglomerado com negócios em variados setores da economia, lançou a fita-cassete ${ }^{147}$, contendo tecnologia que utilizava o mesmo fundamento do gravador de rolo, a fita magnética, entretanto com sistema que a armazenava

145 "The Beatles and their affiliated companies have been some of the most litigious musicians ever. They have even sued each other and fought over rights in countless lawsuits brought against unauthorized users of their works. They have steadfastly refused to license their music for most soundtracks and compilations, and they vigorously defend their rights when samples are used". (KUSEK e LEONHARD, The future of music..., p.49).

146 É interessante notar que a Philips também era uma das principais gravadoras da época, com importantes negócios no segmento ao redor do mundo, inclusive no Brasil, onde em 1958 adquiriu a Companhia Brasileira de Discos (CBD), tendo lançado importantes discos com os artistas do movimento da "Bossa Nova" Baden Powell, Carlos Lyra, Silvia Telles, Aracy de Almeida, Lúcio Alves e Vinícius de Moraes. Cf. sítio internet da Universal Music do Brasil (Disponível em: <http://www.universalmusic.com.br/ quemsomos.asp>. Acesso em: 12 nov. 2006).

147 Em paralelo, em 1952, o americano Bernard Cousino criou uma tecnologia que consistia num cartucho onde pequenos pedaços de fita tocavam sons ininterruptamente por meio de mecanismo interno de roldanas. Tal tecnologia foi aprimorada por George Eash e desde 1959 passou a ser largamente utilizada pelas emissoras de rádio americanas para anúncios de abertura e fechamento de programas de rádio, bem como comerciais. Em 1962, Earl "Madman" Muntz vislumbrou potencial de utilizar as gravações de músicas em cartuchos para audição nos carros, onde até então somente as rádios possibilitavam a audição de músicas. Assim, licenciou álbuns de música popular das principais gravadoras e passou a oferecê-los ao público consumidor. A tecnologia dos cartuchos perdurou até o final dos anos 70, quando sucumbiu perante a fita-cassete principalmente pelo fato de que, ao contrário desta, o cartucho não podia ser gravado em casa, já era comprado com o seu conteúdo (Cf. MORTON. David. A History of The Eight Track Tape. Disponível em: <http:/www.wgeneration.com/70f4.html>. Acesso em: 12 nov. 2006). 
dentro de um invólucro de plástico, de tamanho reduzido e portátil, que contava com boa capacidade de gravação.

Junto com a fita-cassete foi lançado seu aparelho leitor, o chamado "toca-fitas" e, também, aparelhos que tinham a função tanto de ler quanto de gravar sons, tornando fácil a tarefa de duplicar obras musicais, incluídas aquelas fixadas em fonogramas sob forma de disco de vinil (LPs), que já contavam com a proteção normativa contra a reprodução.

Se, pouco antes, a única chance de se obter sucesso no show business era a vinculação a uma gravadora, que detinha o sofisticado aparato necessário para a produção de LPs, com a inovação da fita-cassete o cenário timidamente começou a mudar e possibilitou que os músicos pudessem gravar suas interpretações, mesmo que de forma amadora e com significativa perda de qualidade em relação aos discos de vinil, mas ao menos passaram a ter uma nova opção, da qual lançavam mão para divulgar seus trabalhos artísticos ao público.

Com efeito, parece claro que o intuito da Philips, ao desenvolver e lançar a fitacassete era possibilitar que os músicos gravassem suas interpretações musicais, amadoras ou profissionais, mas também que pessoas comuns gravassem o que bem desejassem nessa invenção, e não que copiassem seus discos de vinil para esse novo meio e oferecessem tais cópias aos seus amigos. Mas é fato que foi isso que passou a ocorrer.

Ao mesmo tempo em que a Philips passou a colher os frutos do enorme sucesso de vendas de sua invenção, na qualidade de ser uma das principais gravadoras passou a se sentir prejudicada pela transferência das músicas para as fitas-cassete, efetuada pelos usuários sem o pagamento de direitos autorais, os quais supostamente deixariam de adquirir os discos de vinil.

Assim, mais do que simplesmente transferir os álbuns do LP para a fita-cassete, os consumidores de músicas passaram a montar as próprias coletâneas ${ }^{148}$, criando novos hábitos e modificando a rígida imposição da indústria fonográfica, que selecionava as músicas que comporiam o disco, geralmente incluindo somente uma ou duas faixas que cairiam no gosto do público e, conseqüentemente, fariam sucesso.

148 Para interessante artigo jornalístico sobre o tema das chamadas tape mix consultar DORIA, Pedro. Perda de capricho. O Estado de S. Paulo, São Paulo, 27 nov. 2006, Caderno Link, p.L12. No Brasil, a inovação introduzida pela fita-cassete possibilitou também o acesso dos ouvintes a obras musicais e artistas que não eram aqui lançados, já que viajantes internacionais traziam LPs em suas bagagens e promoviam a transferência para as fitas-cassete, que eram revendidas ou presenteadas aos amigos, possibilitando o acesso a uma diversidade maior de músicas e estilos musicais. 
As próprias gravadoras podiam lançar seus álbuns em um formato mais barato, o que era especialmente importante para minimizar os riscos do lançamento de novo artista.

Porém, a indústria fonográfica sentiu-se ameaçada pela nova tecnologia, por entender que a transferência de músicas fixadas em LP para a fita-cassete infringia os direitos autorais. Para tal entendimento tomou por base a interpretação da legislação autoral vigente no Brasil, inserida no Código Civil, notadamente o artigo 649, que dispunha: "Ao autor de obra literária, científica, ou artística pertence o direito exclusivo de reproduzi-la", direito cujo exercício era conferido à gravadora após a fixação do fonograma pela previsão expressa no artigo 4. ${ }^{\circ}$ da Lei n. ${ }^{\circ} 4.944$ de 6 de Abril de 1966149: "Cabe, exclusivamente, ao produtor de fonogramas autorizar ou proibir-lhes a reprodução, direta ou indireta, a transmissão, a retransmissão pelos organismos de radiodifusão e execução pública por qualquer meio."

Nesse momento tornou-se mais visível um tema sempre conflituoso no cenário musical: o interesse do público consumidor do produto musical versus o interesse patrimonial das gravadoras, ferrenhas opositoras das possibilidades trazidas pela tecnologia que constituíssem ameaça a seus faturamentos. Para tanto, lançavam mão do discurso de defesa dos direitos autorais.

É importante notar que o sentimento do público consumidor de música era de que não estava fazendo algo ilícito ao transferir o conteúdo de seus discos para o novo meio, por entender que seria ilógico pretender que alguém que já dispusesse do LP legitimamente adquirido, por meio do qual lhe era conferida a licença para uso privado, fosse proibido de utilizá-lo no novo formato de fita-cassete, que apresentava vantagens, a exemplo das possibilidades de ser ouvido no automóvel e de ser selecionada coletânea com as músicas de preferência.

O acima exposto era corroborado pela interpretação da limitação ao direito de autor contida no artigo 666, VI do Código Civil de 1916: "Não se considera ofensa aos direitos de autor: A cópia, feita à mão, de uma obra qualquer, contanto que se não destine à venda."

Os defensores da licitude de tal cópia alegavam, também, sob o aspecto formal, que o que se vedava era a reprodução e que ela não acontecia, mas sim tão-somente uma mudança, uma transferência de formato, do LP para a fita-cassete.

149 Lei que internalizou no ordenamento jurídico pátrio a Convenção de Roma, de 1961. 
Por outro lado, a transferência para a fita-cassete com finalidades comerciais, que também surgiu, era evidentemente abusiva e lesiva aos direitos autorais, ilegal e imoral, pois possibilitava lucro a uns que nada investiam em detrimento dos direitos autorais, o que constituía verdadeiro enriquecimento ilícito, além de não contar com a proteção da exceção aos direitos autorais contida no mencionado artigo 666, VI do Código Civil de 1916.

Passados o susto e o torpor iniciais, a indústria fonográfica reagiu fortemente, buscando a censura de uma atividade que já estava abertamente sendo praticada. Ao invés de compreender tal fenômeno e optar por modelos alternativos de negócios, que contemplassem o ponto principal da nova tecnologia - o inevitável fato de que foi dado poder ao consumidor, na medida em que ele mesmo poderia decidir o que iria gravar na fita - preferiu lançar mão de campanhas educativas por meio de ações de marketing e de lobbies ao redor do mundo, que visavam ao recrudescimento das sanções civis e à criminalização do usuário comum, eventual infrator da lei feita "sob medida e encomenda".

A pressão surtiu efeito no âmbito normativo internacional, já que em 1971 foi firmada a Convenção para a Proteção dos Produtores de Fonogramas contra Duplicação Não-autorizada de seus Fonogramas, na qual se prevê a proteção quanto à duplicação em qualquer forma, com o que se abrangeu a cópia para qualquer formato, inclusive a fitacassete. Ao invés de se ampliar o conceito de reprodução preferiu-se inovar e criar tal nova conceituação, de forma que não fosse deixada margem a interpretações diversas.

É a definição de duplicata, de acordo com essa Convenção: "Artigo 1(c) 'duplicata' significa um artigo que contém sons tirados diretamente ou indiretamente de um fonograma e no qual se inclui todo ou substancial parte dos sons fixados neste fonograma"150.

A Convenção previu que os Estados contratantes tomariam as medidas para proteger os produtores fonográficos quanto às duplicatas e sua importação, que somente poderiam ser realizadas mediante autorização desses produtores ${ }^{151}$. Foi também previsto que a proteção poderia ser feita com legislação de direitos autorais, concorrência desleal e com

150 Tradução livre de "(c) 'duplicate' means an article which contains sounds taken directly or indirectly from a phonogram and which embodies all or a substantial part of the sounds fixed in that phonogram".

151 Convenção para a Proteção dos Produtores de Fonogramas contra Duplicação Não-autorizada de seus Fonogramas. Artigo 2..': "Each Contracting State shall protect producers of phonograms who are nationals of other Contracting States against the making of duplicates without the consent of the producer and against the importation of such duplicates, provided that any such making or importation is for the purpose of distribution to the public, and against the distribution of such duplicates to the public." 
sanções penais ${ }^{152}$. Esse Tratado entrou em vigência no Brasil em 24 de dezembro de 1975, mediante o Decreto n. ${ }^{\circ} 76.906$.

Em 24 de julho de 1971, houve a Revisão de Paris da Convenção de Berna e, a exemplo da Convenção para proteção dos produtores de fonogramas, foi internalizado no Brasil somente em 1975, por meio do Decreto n. ${ }^{\circ} 75.699$, de 6 de maio daquele ano, que previa, no seu artigo 9. ${ }^{\circ}$ :

1) Os autores de obras literárias e artísticas protegidas pela presente Convenção gozam do direito exclusivo de autorizar a reprodução destas obras, de qualquer modo ou sob qualquer forma que seja.

2) Às legislações dos países da União reserva-se a faculdade de permitir a reprodução das referidas obras em certos casos especiais, contanto que tal reprodução não afete a exploração normal da obra nem cause prejuízo injustificado aos interesses legítimos do autor.

3) Qualquer gravação sonora ou visual é considerada uma reprodução no sentido da presente Convenção. [grifo nosso]

Percebe-se que, no decorrer dessa crise, a indústria fonográfica buscou, de maneira incisiva, a ampla e expressa proteção normativa, o que foi feito na revisão da Convenção de Berna por meio das expressões destacadas "de qualquer modo ou sob qualquer forma que seja" e "qualquer gravação sonora ou visual é considerada uma reprodução no sentido da presente Convenção". De modo inequívoco se abrangem a fitacassete e qualquer outro novo meio que a partir daí fosse inventado.

Importante notar que havia permissivo no item 2 do artigo 9 da Convenção acima aludida no sentido de que as leis nacionais poderiam permitir a reprodução das obras protegidas em certos casos especiais, contanto que tal reprodução não afetasse a exploração normal da obra nem causasse prejuízo injustificado aos interesses legítimos do autor ${ }^{153}$.

É com base nisso que surgiu mais um ponto de conflito entre a indústria fonográfica e o público consumidor, já que em 1. ${ }^{\circ}$ de janeiro de 1974 entrou em vigor, no Brasil, antes, portanto da internalização de ambas as normas internacionais acima mencionadas, a Lei n. 5.988 de 14 de dezembro de 1973, o chamado "Código do Direito Autoral", à época internacionalmente reconhecido como um diploma inovador e completo, o qual autorizava

152 Convenção para a Proteção dos Produtores de Fonogramas contra Duplicação Não-autorizada de seus Fonogramas. Artigo 1. : "The means by which this Convention is implemented shall be a matter for the domestic law of each Contracting State and shall include one or more of the following: protection by means of the grant of a copyright or other specific right; protection by means of the law relating to unfair competition; protection by means of penal sanctions."

153 É o "teste dos três passos" ou o "three steps test", conforme já tratado no item 1.1.4 deste estudo. 
a reprodução, em um exemplar, de obra autoral, portanto também a gravação de fonograma em fitas-cassete, em seu artigo 49: "Não constitui ofensa aos direitos do autor: II - A reprodução, em um só exemplar, de qualquer obra, contando que não se destine à utilização com intuito de lucro".

As gravadoras entendiam que as Convenções posteriormente introduzidas no ordenamento jurídico brasileiro, em especial a Convenção de Berna, por específicas que eram e por gozarem, à época, na hierarquia normativa, do mesmo status de lei ordinária ${ }^{154}$, teriam ab-rogado o artigo 49, II do Código do Direito Autoral e que o permissivo do item 2 do artigo 9. ${ }^{\circ}$ da Convenção de Berna deveria ser interpretado no todo, com o entendimento de que a reprodução ou duplicação de fonogramas afetaria a exploração normal da obra e causaria prejuízo aos interesses legítimos do autor.

Em sentido contrário entendiam os usuários, os quais advogavam pela aplicação do disposto na Lei de 1973, elaborada após o tratado, mas antes de sua internalização, sob o argumento de que a exceção da lei configurava justamente o caso especial previsto no tratado e que sua aplicação não causaria prejuízo injustificado aos interesses legítimos do autor e, mesmo que causasse, não seria injustificado, na medida em que o que era autorizada era a cópia pessoal, sem intuito de lucro.

O fato é que as fitas-cassete continuaram a ser gravadas e não havia qualquer possibilidade prática de evitar-se tal hábito do público consumidor ${ }^{155}$.

154 Cf. Terceira Turma do Superior Tribunal de Justiça em relação a conflito entre os mencionados diplomas mas sob outro enfoque (duração), dirimido no REsp 74376 / RJ, "TRATADO INTERNACIONAL - LEI ORDINARIA - HIERARQUIA. O TRATADO INTERNACIONAL SITUA-SE FORMALMENTE NO MESMO NIVEL HIERARQUICO DA LEI, A ELA SE EQUIPARANDO. A PREVALENCIA DE UM OU OUTRO REGULA-SE PELA SUCESSÃO NO TEMPO. DIREITO DE AUTOR. A OBRIGAÇÃO ASSUMIDA PELO BRASIL DE PROTEÇÃO DO DIREITO AUTORAL, NO CAMPO INTERNACIONAL, NÃO SIGNIFICA DEVA SER OUTORGADA AQUELA QUE TEM O AUTOR EM SEU PAIS, MAS QUE SERA DISPENSADO O MESMO TRATAMENTO CONCEDIDO AOS SOB SUA JURISDIÇÃO. (REsp 74.376/RJ, Rel. Ministro EDUARDO RIBEIRO, TERCEIRA TURMA, julgado em 09.10.1995, DJ 27.11 .1995 p.40887)". [grifo nosso]. Importante notar que tal entendimento do STJ vem em decorrência da decisão do Supremo Tribunal Federal, em julgamento ocorrido em 1977, RE 80004/SE, Relator Min. Xavier de Albuquerque, voto vencido, onde, por maioria e com intensas e prolíficas discussões teóricas entre os Exmos. Ministros, prevaleceu o entendimento de que tratado e lei ordinária situam-se no mesmo grau de hierarquia.

155 Muitas discussões foram tomadas nesse tema, as quais somente tiveram ponto final com o aparecimento da tecnologia digital, nos anos 1980, mediante a introdução do Compact Disc (CD), quando a gravação em fitas-cassete passou a ser colocada em segundo plano, pois a perda de qualidade sonora na duplicação de CD para fita-cassete era grande, o que não mais justificava mais tal atitude por parte do usuário. 
Conforme já mencionado, justo no auge da terceira crise do direito de autor na música, com a popularização da fita-cassete, entrou em vigor a Lei n. ${ }^{\circ}$ 5.988/73. Tal lei, acompanhando a evolução do segmento musical e na esteira dos vários tratados internacionais sobre o tema, ampliou a regulação, no que diz respeito à obra musical.

O disco Long Play (LP) de vinil, as fitas-cassete e a radiodifusão constituíram, até os anos 1980, as formas pelas quais o público tinha acesso à musica. Tratava-se de uma atitude passiva do usuário de música, de forçosa aceitação do que a indústria fonográfica oferecia. Artistas que não possibilitassem perspectivas de bom faturamento eram desde logo descartados. Se, a despeito da falta de apelo popular fossem bons artisticamente, restava ainda a opção do lançamento de suas obras por uma gravadora independente, as chamadas "indies", que percebiam um nicho de mercado, arriscavam-se na produção dos discos e, com alguma sorte, conseguiam fazer emplacar algum sucesso, o qual, ironicamente, acabava por ser oferecido ao público em conjunto com as majors ${ }^{156}$, por meio da formidável estrutura de distribuição de alguma delas.

Por fim, emblemática foi a campanha "home taping is killing music" (em vernáculo algo como "a gravação de fitas-cassete em casa está matando a música"), iniciada pela British Phonographic Industry, a associação que congrega e representa a indústria fonográfica britânica, fundada justamente para combater a denominada "pirataria ${ }^{157 " . ~ A l i a ́ s, ~ o ~ s i ́ m b o l o ~}$ de tal campanha remetia diretamente ao símbolo pirata, conforme se vê a seguir ${ }^{158}$ :

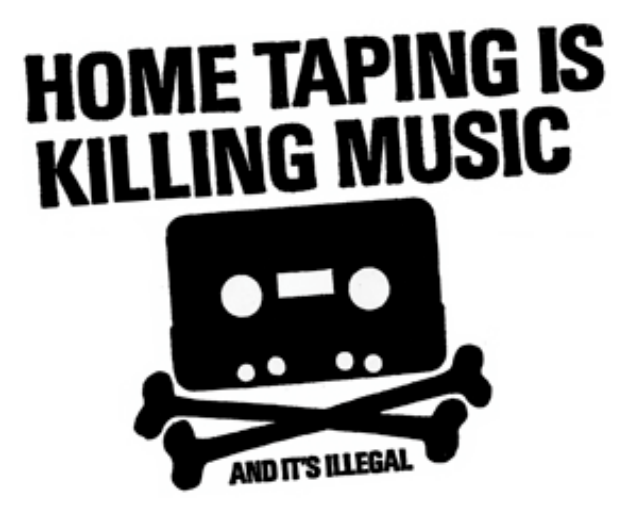

156 Termo utilizado no meio fonográfico para designar as maiores gravadoras.

157 "Nella disciplina del diritto d'autore con il termine 'pirateria' si indica tradizionalmente la violazione dei diritti esclusivi riconosciuti dalla legge ai titolari del diritto d'autore e dei diritti connessi commessa a fini di lucro o comerciali." (De ANGELIS, La tutela giuridica..., p.14).

158 Logomarca extraída de <http://www.theregister.co.uk/2006/06/07/bpi/>. Acesso em: 19 nov. 2006. 
Foi nesse ambiente que vigeu a Lei . $^{\circ} 5.988 / 73$, elaborada sob a influência da Convenção de Roma, de 1961.

\subsection{A QUARTA CRISE DO DIREITO AUTORAL NA MÚSICA: O SURGIMENTO DO COMPACT DISC (CD)}

Em 1982 a Philips introduziu, em conjunto com a Sony ${ }^{159}$, a tecnologia do Compact Disc (CD), que consiste em um disco de policarbonato utilizado para armazenar dados digitais de áudio. Tal meio possibilita a fixação da obra musical e a posterior extração de sons com ausência de ruídos.

O lançamento do Compact Disc foi cuidadosamente planejado, acompanhado por massiva campanha publicitária e oferta imediata aos consumidores de grande quantidade de aparelhos leitores. Tanto a Philips quanto a Sony eram corporações que possuíam seus braços fonográficos e ansiavam por frear os prejuízos que estavam tendo com a duplicata dos LPs para fitas.

Do ponto de vista técnico, as empresas elaboraram um padrão a ser seguido por aqueles que quisessem se utilizar da tecnologia, com parâmetros descritos em um documento denominado "livro vermelho ${ }^{160 "}$. Tal estratégia funcionou, e tanto os fabricantes de produtos eletrônicos quanto as gravadoras adotaram o padrão proposto, o que fez com que o CD em pouco tempo substituísse o LP no mercado, em vista das vantagens que apresentava em relação ao antigo meio físico.

159 É interessante perceber que foi a equipe da Philips que iniciou os estudos acerca da possibilidade de armazenamento de conteúdos, inicialmente figuras, por intermédio da tecnologia óptica. No final dos anos 1970, após diversos anos de pesquisas e protótipos, a Philips decidiu por discutir com a Sony acerca dos parâmetros técnicos para o possível lançamento do que seria o Áudio CD. Finalmente, em 31 de Março de 1982 a tecnologia foi apresentada ao público, como um projeto que envolvia a Philips e seu braço fonográfico Polygram, a Sony e seu braço fonográfico CBS/Sony (Cf. informações disponíveis nos sítios internet das empresas mencionadas, disponíveis em: $<$ http://www.research.philips.com/newscenter/ dossier/optrec/index.html > e <http://www.sony.net/Fun/SH/1-20/h5.html>, bem como IMMINK, Kess A. Schouhamer. The compact disc history. J. Audio Engineering Society, v.46, n.5, p.458-465, maio 1998. Disponível em: <http://www.exp-math.uni-essen.de/ immink/pdf/cdstory.pdf>. Todos os acessos efetuados em 29 de novembro de 2006.

160 "The Red Book or system description CD-Digital Audio (CD-DA) specifies the CD Digital Audio disc format including CD Graphics, CD (Extended) Graphics, CD TEXT, CD-MIDI, CD Single (8cm), CD Audio Maxi-single $(12 \mathrm{~cm})$ and CDV Single $(12 \mathrm{~cm})$. The description includes Main parameters, Audio specification, Disc specification, Optical stylus, Modulation system, Error correction system and the Control \& Display system. (Latest version May 1999.)" (Informação extraída do sítio internet da Philips. $<$ http://www.licensing.philips.com/information/cd/audio/>. Acesso em: $10 \mathrm{dez}$. 2006). 
A perspectiva da indústria fonográfica era que os consumidores trocassem suas coleções de LPs por outra em formato digital. E isso efetivamente ocorreu, com o que se pagava duas vezes pela mesma música, somente em meio físico diferente. Um bom negócio para as gravadoras.

Poucas empresas investiram nos equipamentos necessários para a fabricação do meio físico para a nova tecnologia digital. A maioria preferiu contratar com sociedades constituídas especificamente para essa finalidade. Operou-se, assim, importante modificação no modelo de negócios do segmento musical, com a introdução da cultura da terceirização, de modo que às gravadoras restou a seleção dos artistas, desenvolvimento das estratégias de marketing, logística de distribuição dos CDs e gestão dos direitos autorais.

As gravadoras passaram a experimentar verdadeiro "mar de almirante", já que vendiam números gigantescos de Compact Discs e a única possibilidade de copiá-los era para uma fita-cassete. Nesse caso, todavia, a perda de qualidade era tão grande que não se justificava tal cópia, além do contratempo que era "rebobinar" a fita para localizar a faixa musical pretendida. No CD tudo era automático. Se o usuário quisesse, por exemplo, escutar a terceira faixa de um álbum bastava somente selecioná-la em seu aparelho leitor.

A qualidade sonora oferecida pelo novo meio era muito boa, já que os níveis de ruídos presentes nas gravações podiam ser digitalmente retirados, assim como incluídos, na edição técnica musical, novos instrumentos e sons dos mais variados, que complementavam a composição.

Assim, depois de combalida pela utilização em massa das fitas-cassete para a duplicação dos LPs, a indústria fonográfica, tal qual fênix, ressurgiu das cinzas.

\subsubsection{O Relançamento, pelas Gravadoras, de Fonogramas do "Catálogo" no "CD"}

A popularização da tecnologia do CD fez com que em pouco tempo o "toca-disco" fosse aposentado. A indústria eletrônica vendia milhões de aparelhos reprodutores de $\mathrm{CD}$, enquanto a indústria fonográfica, por sua vez, estava satisfeita pela enorme venda de discos contendo lançamentos de novos álbuns de seus artistas contratados e também pela possibilidade de relançar, no novo meio, os chamados "catálogos", que eram os álbuns lançados em outros tempos, mas que agora eram oferecidos aos mesmos usuários que já os tinham no formato LP. 
Importante ressaltar que o relançamento, no novo meio, de antigos álbuns do "catálogo" das gravadoras era feito, muitas vezes, ao arrepio e mesmo com o desconhecimento dos compositores e intérpretes, aqueles titulares do direito de autor e esses de direitos conexos, sob a interpretação de que pelo fato de serem, as gravadoras, titulares de direitos conexos por haverem fixado os fonogramas ou serem cessionárias dos direitos patrimoniais de determinados álbuns, livremente poderiam regravá-los no novo meio. A partir daí, simplesmente produziam e vendiam os CDs, inclusive sem o pagamento dos direitos autorais ou conexos a quem de direito.

Não deixa de ser interessante notar, outrossim, que tal interpretação extensiva era, de certo modo, aquela dos usuários de LPs em relação às transferências que faziam para as fitas-cassete: de que, uma vez que haviam adquirido o meio físico e obtido com isso a licença de execução privada conferida por tal aquisição, podiam adequá-lo à nova tecnologia.

Noutras palavras, dois pesos e duas medidas. Enquanto, por um lado, a indústria fonográfica poucos anos antes lutou contra a transferência do conteúdo dos LPs para o então novo meio físico das fitas-cassete - lançando mão de campanhas publicitárias e lobbies, que resultaram na modificação e no recrudescimento da normativa internacional e, conseqüentemente, nacional -, por outro, significativa parcela da mesma indústria, ao ser questionada pelos titulares de direitos autorais aos quais não solicitou as devidas autorizações para os relançamentos de composições ou álbuns dantes gravados em LPs para o novo meio físico $\mathrm{CD}$, passou a argumentar que se tratava de mera adequação aos novos meios tecnológicos, contratualmente respaldada.

Na década de 1980, quando surgiu o Compact Disc, vigia no Brasil a Lei n. ${ }^{\circ}$ 5.988/73, a qual dispunha que: "Art. 53. A cessão total ou parcial dos direitos do autor, que se fará sempre por escrito, presume-se onerosa. $\S 2{ }^{\circ}$ Constarão do instrumento do negócio jurídico, especificamente, quais os direitos objeto de cessão, as condições de seu exercício quanto ao tempo e ao lugar, e, se for a título oneroso, quanto ao preço ou retribuição". Era esse dispositivo legal, em conjunto com o artigo 98 da mesma Lei ${ }^{161}$, que as gravadoras

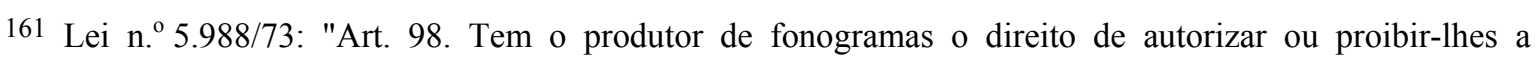
reprodução, direta ou indireta, a transmissão e a retransmissão por empresa de radiodifusão, bem como a execução pública a realizar-se por qualquer meio." 
interpretavam como sendo o permissivo para o relançamento dispensado de autorização e mesmo remuneração dos compositores e intérpretes, das obras musicais que lhes convinham, no novo formato $\mathrm{CD}$, uma vez que as cessões que com eles operavam eram, via de regra, em caráter definitivo.

Tal entendimento foi alvo de oposição por parte dos compositores e dos intérpretes, que passaram a questionar tanto a ausência da autorização quanto, em alguns casos, o não-pagamento dos direitos patrimoniais correspondentes. A solução, entretanto, dependia de quem protestava. Se tivesse renome artístico e a gravadora ainda se interessasse numa relação contratual, não deixava que a reclamação fosse levada ao Poder Judiciário e providenciava o acordo extrajudicial, da maneira mais silenciosa possível para evitar a criação de precedente. Por outro lado, se quem reclamava estava no ostracismo ou em contrato vigente com uma concorrente, só restava a via judicial.

Os autores ou intérpretes que decidiam buscar o resguardo do Poder Judiciário, via de regra, se deparavam com um entendimento contrário aos seus interesses ${ }^{162}$, no sentido de que não havia ato ilícito no relançamento de fonograma em $\mathrm{CD}$, sob a alegação de que a titularidade dos direitos patrimoniais havia sido transferida ${ }^{163}$.

Há que se notar, entretanto, que algumas das decisões em demandas nas quais eram partes somente intérpretes e gravadoras, sem constar o compositor, o pleito indenizatório não foi acolhido, tendo sido decidido pela validade do caráter definitivo da cessão dos direitos de interpretação para regravações em qualquer forma, ainda que não existente à época do contrato. Entretanto, é de interessante leitura a decisão representada pelo Acórdão 5.112/2000, da 16. ' Câmara Cível do Tribunal de Justiça do Rio de Janeiro, Relator

162 Nesse sentido, TJ/RJ - APELAÇÃO CÍVEL 2003.001.05541 Rel. DES. GAMALIEL Q. DE SOUZA Julgamento: 29/04/2003 - DECIMA SEGUNDA CÂMARA CÍVEL - AÇÃO DE INDENIZAÇÃO DIREITO AUTORAL - COMERCIALIZACAO - USO INDEVIDO - NÃO CARACTERIZAÇÃO AÇÃO ORDINÁRIA DE INDENIZAÇÃO POR USO INDEVIDO DE FONOGRAMA - A alegada prática de ato ilícito decorrente de lançamento, sem autorização de produtos fotográficos, não se verificou, porque sendo a recorrida detentora dos direitos autorais, não se fazia necessária autorização, existente nos contratos de cessão, firmados, sem limite temporal, não se operando, por conseguinte a caducidade sustentada pela ré, como se pode inferir do que está consignado na cláusula 9 . $^{\text {a }}$ do instrumento celebrado, em 21.05.76 - Improvimento do recurso".

163 Muito embora já em 1951 Pedro Vicente Bobbio mencionasse o "principio geral, hoje pacífico, que a cessão de direitos feita por autor a terceiro, mesmo geral e genérica, só é compreensiva aos direitos patrimoniais existentes no momento e não se estende aos acrescidos de futuro, salvo clausula expressa", sendo que certa a impossibilidade de se se expressar o que se desconhecia. (BOBBIO, $O$ direito de autor..., p.18). 
Des. Miguel Ângelo Barros ${ }^{164}$, no qual há a reconhecimento expresso da diferenciação entre o estatuto jurídico do intérprete e do compositor, mesmo sob a égide da lei antiga, o que consistia em novidade, uma vez que, na maioria das decisões, não parecia importar para o julgador tal basilar diferenciação. Essa decisão, tomada em 2000 - muito embora sob os auspícios da legislação de 1973 -, certamente foi norteada pelos ventos da nova legislação de 1998, o que infelizmente outras decisões não o fizeram.

Contudo, tal conflito, instaurado a partir de negócio jurídico ${ }^{165}$ de cessão patrimonial de direitos autorais, bem demonstrou que a legislação que deveria proteger o autor, paulatinamente passou a ser interpretada em seu desfavor e que o recrudescimento das normas, perceptível em toda a história recente da disciplina do direito autoral, acaba por beneficiar tão-somente o investidor.

Isso se diz em vista da interpretação dos tribunais, em casos em que a parte hipossuficiente (no caso os autores e intérpretes) geralmente restavam vencidas e condenadas ao pagamento dos ônus de sucumbência. Em outras palavras, aquele que ousasse demandar contra as gravadoras, além de ficar mal-visto no mercado, perdia a causa e tinha que desembolsar as despesas do processo e os honorários dos patronos da parte contrária.

O acima exposto seria até aceitável se decorresse da melhor interpretação da lei então vigente, por parte dos tribunais, em especial em relação ao autor. Mas não parece ser o caso. Para demonstrar o desacerto do entendimento então dominante, analise-se um caso

164 "Direito autoral. Interprete. Direitos sobre fixação. Cessão. Caráter definitivo. Possibilidade. Relançamento. Direito do cessionário. 1. O intérprete de obras musicais, ao contrário do autor, pode ceder a um produtor, em caráter definitivo, os seus direitos sobre determinadas interpretações fixadas em meio magnético terminado o prazo contratual ou rescindindo o contrato de exclusividade, ele pode fazer nova fixação da mesma obra, hipótese em que poderão conviver no mercado o relançamento das fixações antigas e o lançamento da nova fixação. 2. Sendo detentor dos direitos sobre diversas interpretações de diferentes obras musicais fixadas por determinado intérprete em ocasiões diferentes, o produtor pode relançá-las independentemente de autorização do intérprete, reunidas da mesma forma que no lançamento original ou de forma diferente, desde que pague ao interprete a remuneração contratual. 3. Apelação a que se nega provimento. (SCK) Vencido o Des. Ely Barbosa, que dava provimento ao recurso". 2000.001.05112 - APELAÇÃO CÍVEL, DES. MIGUEL ANGELO BARROS - Julgamento: 30/05/2000 - DÉCIMA SEXTA CAMARA CÍVEL, TJ/RJ. No mesmo sentido, com as mesmas partes: "Direito autoral. Contrato de cessão onerosa de interpretações fixadas, garantidas com exclusividade. Ação ordinária objetivando recebimento de indenização ao fundamento de terem ocorrido regravações não autorizadas. Improcedência. Apelação. O relançamento de fonogramas, cedidos pelo interprete `a gravadora, apos o vencimento do contrato, não constitui ato ilícito e não dá ensejo à reparação de danos se se pactuou de forma expressa o direito de regravações, mesmo apos o vencimento do contrato. Provimento parcial. (ETA)". TJ/RJ. Apelação Cível 3616/2002, 5. ${ }^{a}$ Câm. Cível, Rel: Des. Carlos Ferrari.

165 "Como em toda a transferência, entre vivos, de domínio, a transferência da propriedade intelectual supõe negócio jurídico básico e o acôrdo de transmissão". (PONTES DE MIRANDA, Tratado de direito privado, Tomo XLIV, p.321). 
hipotético: o autor X, em 1974, opera com a gravadora XYZ, cessão total de direitos patrimoniais referentes a determinado álbum, contendo canções de sua autoria e interpretação. O LP é produzido, gravado, lançado e posto à venda. Tem um sucesso razoável de público. Pelos idos dos anos 1990, um autor de telenovelas entende que uma das músicas de X se encaixaria de forma perfeita em sua obra.

Assim, a emissora de televisão entra em contato com a XYZ e negocia o direito de sincronização referente àquela música, a qual, movida pela perspectiva de altos lucros, decide relançar o álbum, agora em formato Compact Disc, sem sequer comunicar o X.

Tal exemplo reflete muitos casos concretos e tem a seguinte leitura jurídica, sob o entendimento da indústria fonográfica e da jurisprudência dominante: a) as partes, em conformidade com o disposto no artigo 53, $\S 2 .^{\circ}$ da Lei n. $.^{\circ} 5.988 / 73^{166}$, então vigente, operaram cessão total e definitiva, negócio jurídico perfeito que abrangia tanto o direito de autor de $\mathrm{X}$ como compositor quanto o seu direito conexo de interpretação, o que tornou a XYZ perpétua titular de todos os direitos patrimoniais em questão, contratualmente transmitidos às sucessoras; b) à cessão total seria somado o direito conexo disposto no artigo 98 da Lei n. ${ }^{0} 5.988 / 73^{167}$, ou seja, as gravadoras, em relação aos fonogramas, que poderiam "autorizar ou proibir-lhes a reprodução direta ou indireta", sendo que "reprodução", conforme dispunha a mesma lei, era "a cópia de obra literária, científica ou artística bem como de fonograma"168; c) diante disso e sob um raciocínio não-coordenado com os princípios do direito de autor, tem-se que a própria gravadora, já sendo a titular perpétua dos direitos autorais em questão, e acrescendo o fato de que a lei lhe concede o direito de autorizar ou proibir a cópia, logo não existe ato ilícito no relançamento de álbum ou músicas de seu "catálogo" no novo formato "CD".

Os motivos para se discordar do entendimento dominante nos tribunais são, entretanto, relevantes: a) como forma de proteção ao autor, parte historicamente hipossuficiente, a

166 Lei n. ${ }^{\circ}$ 5.988/73 "Art. 53. A cessão total ou parcial dos direitos do autor, que se fará sempre por escrito, presume-se onerosa. $\S 2 .^{\circ}$ Constarão do instrumento do negócio jurídico, especificamente, quais os direitos objeto de cessão, as condições de seu exercício quanto ao tempo e ao lugar, e, se for a título oneroso, quanto ao preço ou retribuição".

167 Lei n. ${ }^{\circ}$ 5.988/73: "Art. 98. Tem o produtor de fonogramas o direito de autorizar ou proibir-lhes a reprodução, direta ou indireta, a transmissão e a retransmissão por empresa de radiodifusão, bem como a execução pública a realizar-se por qualquer meio".

168 Lei n. ${ }^{\circ}$ 5.988/73: "Art. 4. $^{\circ}$ Para os efeitos desta lei, considera-se: IV - reprodução - a cópia de obra literária, científica ou artística bem como de fonograma". 
doutrina construiu e a norma incorporou o princípio da interpretação restritiva nos negócios jurídicos sobre direitos autorais, inclusive aquela vigente à época ${ }^{169}$ da assinatura do instrumento jurídico que operou a cessão; b) o que se protege, e sempre se protegeu, de modo precípuo é o direito do autor e não o direito conexo do produtor fonográfico ${ }^{170}$.

Assim, numa leitura coordenada da legislação autoral vigente à época, abarcando-se tanto o entendimento das gravadoras quanto dos compositores e artistas, conclui-se que a posição dominante nos tribunais era equivocada, especialmente no que diz respeito aos litígios entre autor e gravadora, uma vez que os negócios jurídicos em direitos autorais, no caso a cessão total de tais direitos autorais, devem ser interpretados restritivamente, ou seja, vale a cessão para as formas de utilização então existentes, sendo vedada a extensão para novos meios e, em 1974, não existia o formato Compact Disc.

Noutras palavras, uma vez que o artigo $53, \S 2 .^{\circ}$ da Lei . $^{\circ} 5.988 / 73$ determinava a especificação dos direitos objetos de cessão e das condições de seu exercício quanto ao tempo e ao lugar e, exceto num exercício de futurologia, não havia como constar no documento que o autor cedia totalmente os direitos patrimoniais de sua obra para a gravação no formato $\mathrm{CD}$.

Em vista de o sistema continental ou latino-germânico de autor prever a proteção ao autor (ao contrário do sistema do copyright, de cunho comercial), é esse o espírito das leis autorais dos países filiados a esse sistema, como é o caso do Brasil. Assim, também, se o entendimento fosse de que havia omissão legislativa, essa não poderia ser invocada em detrimento do autor.

Tanto é assim que o legislador, ciente da interpretação dos tribunais e do evidente prejuízo que os compositores estavam tendo, houve por bem dirimir qualquer dúvida ao revogar a legislação de 1973 e incluir expressamente, na Lei n. ${ }^{\circ}$ 9.610/98, hoje vigente, os seguintes dispositivos:

169 Lei n. ${ }^{\circ}$ 5.988/73: "Art. 3. ${ }^{o}$ Interpretam-se restritivamente os negócios jurídicos sobre direitos autorais" e também na legislação que a revogou, a hoje vigente Lei . $^{\circ}$ 9.610/98: "Art. 4 . $^{\circ}$ Interpretam-se restritivamente os negócios jurídicos sobre os direitos autorais."

170 Lei n. ${ }^{\circ}$ 5.988/73: "Art. 94. As normas relativas aos direitos do autor aplicam-se, no que couber, aos direitos que lhes são conexos", previsão repetida na LDA, "Art. 89. As normas relativas aos direitos de autor aplicam-se, no que couber, aos direitos dos artistas intérpretes ou executantes, dos produtores fonográficos e das empresas de radiodifusão." 
Art. 49. Os direitos de autor poderão ser total ou parcialmente transferidos a terceiros, por ele ou por seus sucessores, a título universal ou singular, pessoalmente ou por meio de representantes com poderes especiais, por meio de licenciamento, concessão, cessão ou por outros meios admitidos em Direito, obedecidas as seguintes limitações:

(...)

V - a cessão só se operará para modalidades de utilização já existentes à data do contrato; [grifo nosso]

Art. 89. As normas relativas aos direitos de autor aplicam-se, no que couber, aos direitos dos artistas intérpretes ou executantes, dos produtores fonográficos e das empresas de radiodifusão.

Parágrafo único. A proteção desta Lei aos direitos previstos neste artigo deixa intactas e não afeta as garantias asseguradas aos autores das obras literárias, artísticas ou científicas. [grifo nosso]

Em relação aos intérpretes, fez constar que:

Art. 90. Tem o artista intérprete ou executante o direito exclusivo de, a título oneroso ou gratuito, autorizar ou proibir:

(...)

V - qualquer outra modalidade de utilização de suas interpretações ou execuções. [grifo nosso]

Já como direitos dos produtores fonográficos:

Art. 93. O produtor de fonogramas tem o direito exclusivo de, a título oneroso ou gratuito, autorizar-lhes ou proibir-lhes:

I - a reprodução direta ou indireta, total ou parcial;

II - a distribuição por meio da venda ou locação de exemplares da reprodução;

III - a comunicação ao público por meio da execução pública, inclusive pela radiodifusão;

IV - (VETADO)

V - quaisquer outras modalidades de utilização, existentes ou que venham a ser inventadas. [grifo nosso]

Clarificou-se o que nunca deveria ter sido deixado de lado: o direito de autor deve proteger o autor. Não se pode, simplesmente, importar para o nosso sistema a preponderância do fator econômico presente no copyright.

Resta claro, outrossim, que a nova legislação bem explicita o degrau hierárquico existente entre o autor e os titulares de direitos conexos, ao manter intactas e não afetar as garantias asseguradas aos autores das obras literárias, artísticas ou científicas ${ }^{171}$.

O esclarecimento quanto à impossibilidade de a cessão, pelo autor, incluir novas modalidades de utilização é inequívoco. Além do fato de a legislação ser muito clara, a

171 Parágrafo único do artigo 89 da LDA: "Parágrafo único. A proteção desta Lei aos direitos previstos neste artigo deixa intactas e não afeta as garantias asseguradas aos autores das obras literárias, artísticas ou científicas." 
mensagem de veto $\mathrm{n}^{\circ} .234$ da Presidência da República ${ }^{172}$, mediante a qual se apresentam as razões pelas quais se vetou o inciso IV do artigo 93, cuja redação original era "IV todas as utilizações a que se refere o art. 29 desta Lei a que se prestem os fonogramas", explicitando que tal inciso "é inadequado, uma vez que, em se tratando de direitos conexos, referencia um artigo que trata exclusivamente de direito de autor, o que pode levar a uma equiparação entre esses dois institutos distintos da propriedade intelectual".

Já em relação ao intérprete o tema depende de considerações, visto que tanto ele quanto o produtor fonográfico possuem o mesmo status de titulares de direitos conexos perante a lei, sendo cabível a interpretação de que o inciso V do artigo 90 da LDA é permissivo para que ele autorize "qualquer outra modalidade de utilização de suas interpretações ou execuções", não havendo qualquer vedação temporal ou em relação a novas tecnologias. Ou seja, uma vez expressamente pactuado com o produtor fonográfico a autorização que abranja o contido em tal inciso e também fixado o fonograma, sobre esse o produtor tem os direitos garantidos no artigo 93 da mesma lei, inclusive quanto à transferência para novos meios tecnológicos que venham a ser inventados, naturalmente sem que se interfira no direito do compositor, caso o intérprete também o seja, circunstância em que o direito do produtor de fonogramas submete-se ao direito do autor.

Pode-se, por outro lado, interpretar que o contido no inciso V do artigo 90 não é permissivo mas sim limitador, na medida em que é escrito no singular "qualquer outra modalidade...", o que geraria o entendimento de que se restringe para outra modalidade que seja de uso corrente no momento da autorização. Corrobora tal entender o fato de que no inciso V do artigo 93 está no plural "quaisquer outras modalidades de utilização, existentes ou que venham a ser inventadas", o que dá a sensação de amplitude, de abarcar toda e qualquer outra modalidade de utilização, o que não ocorreria no uso do singular.

Por fim, é de se concluir que o legislador corretamente garantiu proteção ao autor, mas deixou a lacuna a ser colmatada pelos tribunais mediante caso concreto, nas relações entre produtor e intérprete.

172 Mensagem de veto presidencial disponível em: <http://www.planalto.gov.br/CCIVIL/LEIS/Mensagem_ Veto/1998/Vep9610-98.pdf>. Acesso em: 14 jan. 2007. 
1.4.2 A Popularização do CD Regravável: O Prenúncio do Declínio da Indústria Fonográfica nos Moldes Tradicionais

Em 1988, a Philips e a Sony publicaram o Orange Book, contendo especificações sobre mídias regraváveis no formato Compact Disc, o que, na prática, possibilitava que fossem desenvolvidos e fabricados aparelhos que não somente liam mas gravavam dados e áudio, para uso do consumidor final, em seus respectivos computadores pessoais. Por volta de 1990, o CD-R foi lançado para o mercado estadunidense, tendo começado a se disseminar no Brasil durante os primeiros cinco anos daquela década e se popularizado perto do final do século passado.

No início, o preço praticado para a venda do aparelho leitor e gravador era na casa dos milhares de dólares, quantia suficiente a comprar um carro popular. Com o tempo, no entanto, a tecnologia se disseminou e tanto o aparelho óptico quanto os discos regraváveis passaram a ser vendidos por preços muito acessíveis. Em dezembro de 2006 um aparelho custava mais barato do que uma miniatura comum de um carro em escala $1 / 18$, ao mesmo tempo em que a mídia CD-R é vendida, no varejo, pelo preço de um copo de água mineral.

Foi daí que, com a possibilidade e facilidade de se copiar músicas de um CD para outro, a indústria fonográfica experimentou o início de seu declínio ${ }^{173}$. Não somente os usuários duplicavam uns para os outros seus CDs como começou a existir um processo, no início informal, de duplicação e venda com fins comerciais. O disco que era vendido no mercado legal por R\$20,00, nos anos 1990, tinha sua duplicata sendo vendida por entre $\mathrm{R} \$ 5,00$ e R\$10,00.

Foi o início da pirataria dos CDs, consistente na reprodução não-autorizada, portanto ilegal, com finalidades comerciais.

Mas o que a indústria fonográfica fez? Justificando-se pela queda nas vendas causadas pela pirataria, tratou de aumentar o valor de venda dos discos, que ao longo dos anos passou a custar em torno de $\mathrm{R} \$ 30,00$, enquanto os CDs ilegais passaram a ser vendidos, dos vendedores ambulantes para o usuário final a poucos reais, chegando a custar, no centro de São Paulo, o valor de R\$1,00.

173 "By digitizing music and distributing it on the CD, the music industry made it possible for just about anyone to make an infinite number of perfect digital copies of every song ever release on CD. In so doing, the industry opened itself up to the massive changes we're seeing today." (KUSEK e LEONHARD, The future of music..., p.4). 
É fato notório que a indústria fonográfica suporta custos elevados nos seus variados departamentos, dá emprego a pessoas qualificadas, contrata compositores e intérpretes, assume riscos dos mais variados e, principalmente, paga impostos. Atua, no aspecto formal, dentro da legalidade.

Por outro lado, a "indústria informal" baseada na cópia de álbuns já lançados atua de forma absolutamente ilegal. Tão-somente pega um trabalho pronto, escolhendo somente aqueles de intérpretes que já têm sucesso, e se preocupa somente em fazer a duplicação e a distribuição, em larga escala, dos CDs contrafeitos. Não emprega ninguém formalmente, não recolhe nada em direitos autorais, não assume riscos que não aqueles oriundos dos ilícitos que comete e não paga impostos. Além de ilegal é imoral ${ }^{174}$, já que se locupleta do esforço alheio.

A ABPD - Associação Brasileira dos Produtores de Discos informa, em seu sítio na internet ${ }^{175}$, que:

Em 2004, a oferta de produtos piratas se manteve estável no País, com mais da metade do mercado sendo tomado por produtos ilegais, fato que manteve o Brasil no ranking mundial dos 10 mercados mais afetados pelo problema da pirataria física de CDS.

- Os efeitos da pirataria no setor fonográfico período - 1997 A 2004

- Postos de trabalho direto: $-50 \%$.

- Artistas contratados: $-50 \%$.

- N. ${ }^{\circ}$ de pontos de vendas fechados: -2.500 .

- Lançamentos de produtos: Nacional - 44\%.

- Estimativa de perda de arrecadação em impostos em função da pirataria: R\$ 500 milhões anuais (Somente considera ICMS, PIS e Cofins).

- N. ${ }^{\circ}$ de empregos perdidos no setor: - 60 Mil (gravadoras, fabricantes, comércio varejista, etc...).

E, ainda, citando como fonte os dados fornecidos pela APDIF - Associação Protetora dos Direitos Intelectuais Fonográficos, que:

Segundo acompanhamento da APDIF - Associação Protetora dos Direitos Intelectuais Fonográficos, de janeiro a dezembro de 2005, mais de 31 milhões de unidades de CDs ilegais foram apreendidos no país, entre gravados e virgens, 165 pessoas foram presas por crime contra o Direito Autoral. Porém, esse número ainda não pode ser considerado um resultado positivo, uma vez que os

174 O consumidor de tais produtos muitas vezes é lesado ao receber exemplar defeituoso ou que não contém as músicas prometidas, não tendo a quem formalmente reclamar. Graves também são as repercussões no âmbito trabalhista, já que dentre a rede informal de vendedores ambulantes muitas vezes se configura o descumprimento da legislação trabalhista.

$175<$ http://www.abpd.org.br/pirataria_dados.asp>. Acesso em: 14 jan. 2007. 
níveis de pirataria musical vêm aumentando ano após ano e o mercado legal vem se reduzindo seguidamente.

No ranking da entidade, o estado de São Paulo é a região mais afetada, onde o número apreendido passa a casa da 16 milhões de unidades. O Paraná ficou em segundo lugar no ranking com cerca de 9,1 milhões de CDs falsificados apreendidos em 2005 e em terceiro lugar ficou o estado do Rio Grande do Sul, com mais de um milhão de unidades apreendidas.

No total foram acompanhadas 1.745 ações, em todo o país, entre operações de rua (ambulantes e lojas), estouro de laboratórios e depósitos. Foram apreendidos também cerca de 21.094 drives de gravação.

\begin{tabular}{lr|r|r|r|r}
\hline \multicolumn{1}{c|}{ Apreensões } & \multicolumn{1}{c|}{2000} & \multicolumn{1}{c}{2001} & \multicolumn{1}{c}{2002} & \multicolumn{1}{c}{2003} & \multicolumn{1}{c}{2004} \\
\hline CDs Gravados & 3.223 .295 & 2.976 .217 & 3.783 .535 & 5.686 .253 & 3.473 .371 \\
CDs Virgens & 122.165 & 315.643 & 8.649 .590 & 11.455 .421 & 12.168 .818 \\
Drivers de Gravação & 280 & 691 & 847 & 4.883 & 8.238 \\
Pessoas Averiguadas & 1.348 & 1.213 & 1.264 & 1.060 & 1.064 \\
Presos & S/ registros & 8 & 58 & 142 & 149 \\
\hline
\end{tabular}

\begin{tabular}{l|r}
\hline \multicolumn{1}{c|}{ Apreensões } & \\
\hline CDs gravados & Janeiro a Dezembro de 2005 \\
DVDs gravados & 4.177 .104 \\
CDs virgens & 676.982 \\
DVDs virgens & 17.215 .590 \\
Drives de Gravação & 8.453 .776 \\
Pessoas Indiciadas/Averiguadas & 21.092 \\
Pessoas Presas & 1.638 \\
\hline
\end{tabular}

Fonte: Apdif

Da análise dos dados percebe-se que a partir de 2002 a indústria fonográfica centrou o foco de sua atenção nos CDs virgens, matéria-prima para a duplicação de CDs, cujo comércio em si não é, obviamente, proibido, provavelmente por meio de ações nas fronteiras e nos portos, de apreensões justificadas por importações irregulares, ou contrabando, indícios de que iriam parar na mão dos "piratas".

Nos últimos anos, aliás, muito se tem falado da "pirataria", que consiste, conforme já visto neste estudo, na violação dos direitos autorais com finalidade comercial ou lucrativa. Massivas campanhas publicitárias têm lançado mão da idéia de que as quadrilhas mais perigosas, praticantes de toda a sorte de crimes, também são aquelas envolvidas com a pirataria.

Tal entendimento exsurge do seguinte raciocínio: i) vigora lei que garante aos titulares dos direitos autorais os direitos patrimoniais sobre a obra, dentre os quais os de reprodução e de distribuição das cópias; ii) há quem se disponha a concorrer no mercado, na busca do lucro, com os titulares da obra na exploração dos direitos patrimoniais, entretanto sem fazer qualquer pagamento a título de retribuição autoral e sem estar 
disposto a investir sequer ínfima parcela do investimento da indústria fonográfica ou mesmo buscar autorização dos respectivos titulares; iii) tais sujeitos adquirem as mídias (no caso, os CDs) para a reprodução das obras musicais a serem ilegalmente distribuídas no mercado, e isso geralmente o fazem mediante a aquisição de produtos oriundos de importação irregular ou mesmo de contrabando, no caso de pretenderem praticar a contrafação no Brasil ou, então, providenciam a aquisição dos CDs já contrafeitos em outros países e, em conjunção de ilícitos civis, penais e tributários, fazem chegar ao nosso país; iv) para que os produtos ingressem no país, não é incomum a prática do crime de corrupção ativa a funcionários alfandegários e agentes policiais; v) ao fazer a distribuição e oferta à venda, lançam mão de estrutura informal, principalmente de vendedores ambulantes sem autorização para comerciar em logradouros públicos (infração administrativa), os quais, a exemplo dos fornecedores, também não pagam qualquer espécie de imposto.

O modelo de funcionamento desse mercado paralelo é o seguinte:

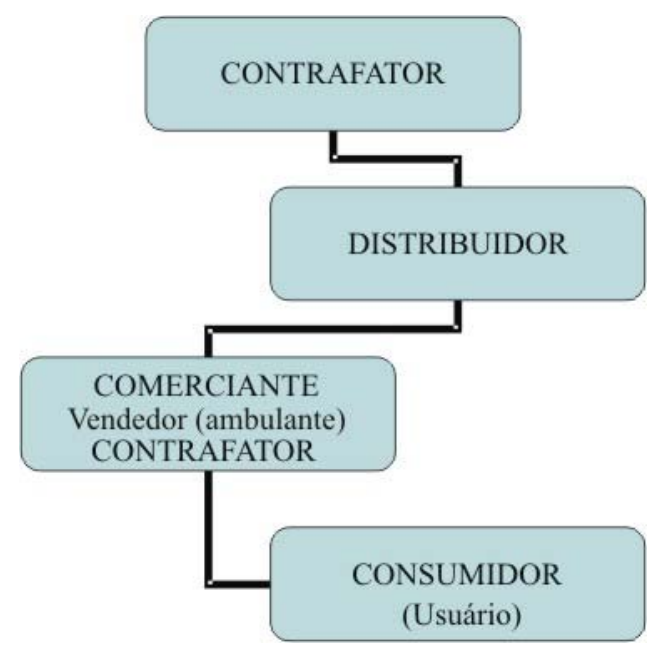

Nesse contexto, não sem razão, os titulares de direitos autorais passaram a protestar pela aplicação da rigorosa legislação existente e a ressaltar ao público a condição de infratores dos contrafatores, já que suas estruturas, embora informais, nada têm de amadoras, antes ao contrário, apresentam níveis bem definidos e sofisticados de atuação e profissionalismo, o que também acaba por justificar a reclamação da indústria fonográfica de que compete com o crime organizado.

Por outro lado, não se pode olvidar que o mercado paralelo de CDs contrafeitos somente existe em virtude de haver um público consumidor disposto a adquirir os produtos, não lhe importando serem originais ou piratas, uma vez que a tecnologia digital 
possibilita a cópia exatamente igual ao original. O usuário de músicas é sedento por variedade musical e o acesso aos discos é efetivamente um fator de exclusão, sendo certo que a grande massa acaba por preferir adquirir CDs de seus artistas prediletos no comércio paralelo. ${ }^{176}$

Ainda, a facilidade na concessão do crédito pessoal ${ }^{177}$, que as redes varejistas têm oferecido de alguns anos para cá, possibilitou que os consumidores das classes mais baixas tivessem acesso aos aparelhos leitores de Compact Disc, no formato dos famosos "micro system", a versão atualizada dos "três-em-um", que continham leitor de Long Play, fitascassete e rádio.

Mas ter um aparelho leitor de CD sem ter os discos é como ter um veículo sem o combustível. Assim, essa massa composta por consumidores de baixa renda se defrontou com os altos preços da cópia de CD legitimamente adquirido, de modo que não havia nem há - como se pretender que tal usuário, mesmo imbuído da melhor boa-vontade, adquirisse legalmente o disco almejado, e isso efetivamente não ocorreu. Os artistas de maior popularidade, representantes da música sertaneja e forró são aqueles que mais sofrem com a pirataria. Não por acaso são eles que mais aparecem nas ações de marketing das gravadoras, em encontros com políticos (várias vezes visitaram os Presidentes Fernando Henrique Cardoso e Lula) e em "cerimônias" de destruição de CDs apreendidos por meio de imensos rolos compressores.

A camada mais pobre da população brasileira não consegue acompanhar pari passu as inovações tecnológicas, por custosas que são. Aqui, o CD ainda poderá ser utilizado por alguns anos, ao contrário do que ocorre, por exemplo, nos Estados Unidos,

176 Informa Ronaldo Lemos que "há, no Brasil, um movimento nas periferias que já pratica a transcendência do modelo do direito autoral tradicional", o qual possibilitou a inclusão musical de pessoas das classes sociais mais baixas, que não tinham como ser consumidores dos CDs no valor praticado pelas gravadoras (LEMOS, Ronaldo. Direito, tecnologia e cultura. Rio de Janeiro: FGV, 2005. p.90). Hermano Vianna trata do fenômeno do "tecnobrega", que ocorre no Pará e representa a total desvinculação da indústria fonográfica tradicional, com os mais de 2000 discos anualmente lançados, gravados no formato MP3 (n.: no capítulo 2 será tratado sobre tal tecnologia) sendo vendidos apenas por camelôs, tudo ocorrendo na total informalidade (VIANNA, Hermano. A música paralela. Folha de S. Paulo, São Paulo, 12 dez. 2003, Caderno Mais!, p.10 e 11). É, também, exemplar o caso da banda Calypso, maior expoente do estilo de mesmo nome, que percebeu o fato dos preços de venda dos CDs praticados pelo sistema tradicional serem onerosos por demasia a seu público-alvo e tratou de lançar, por conta própria, seus primeiros álbuns, os quais foram vendidos a $\mathrm{R} \$ 10,00$ (dez reais) por meio da estrutura informal dos camelôs.

177 Que é crédito fácil para se emprestar mas não necessariamente barato nem fácil para pagar. Aqueles que optam pelos crediários oferecidos pelo comércio varejista e por instituições financeiras chegam a pagar o equivalente a três vezes o valor que pagariam se comprassem o mesmo produto à vista. 
onde a proliferação de tecnologias digitais que se utilizam de compressão de dados aliada à inclusão digital e acesso à internet em banda larga já fez diminuir consideravelmente o mercado dos $\mathrm{CDs}^{178}$, com a quebra de tradicionais varejistas de CDs e LPs, a exemplo da famosa Tower Records ${ }^{179}$.

É o motivo pelo qual a indústria fonográfica, por alguns anos ainda, continuará a promover, em nosso país, a firme defesa de seus interesses em relação às cópias piratas de $\mathrm{CDs}^{180}$, algo que praticamente já deixou de fazer nos países desenvolvidos e agora foca em problemas maiores, como o compartilhamento de músicas pela internet, esses a serem tratados nos próximos capítulos deste estudo.

Para David Kusek e Gerd Leonhard ${ }^{181}$, entretanto, a obsolescência do Compact Disc deve ser interpretada como o fim de um ciclo de reposição, na medida em que aqueles que tinham suas coleções musicais em discos de vinil iam adquirindo os novos meios físicos CDs, quando esses eram lançados, até chegar o momento em que não havia mais o que ser comprado, uma vez que as gravadoras não lançavam novos artistas na velocidade em que o público poderia consumir.

178 De 803,3 milhões de unidades de CDs vendidos em 2002 caiu para 614,9 em 2006. Leve-se em conta que em 2002 o impacto das novas tecnologias já era sentido na indústria fonográfica (RECORDING INDUSTRY IN NUMBERS. London: IFPI, 2007. p.21).

179 A qual requereu falência em 2004 e encerrou suas operações de varejo em lojas "reais" no final de 2006. Atualmente um grupo independente adquiriu o domínio www.tower.com e lançou uma loja "virtual" de músicas digitais.

180 Tanto é assim que em 2007 foi criada a APCM - Associação Antipirataria Cinema e Música, a qual apresentou o primeiro balanço de sua atuação, compreendendo os meses de janeiro a maio de 2007, onde dá conta que o foco precípuo é o combate à pirataria física: "Resumo das Operações - Apreensões Janeiro a Maio de 2007: CDs fonográficos (gravados e virgens) 6.552.156; DVDs fonográficos (gravados e virgens) 2.628.202; Drives de Gravação 9.948; Envolvidos/ Presos 517". (Sítio da ABPD - Associação Brasileira dos Produtores de Discos. Disponível em: <http://www.abpd.org.br/noticias_internas.asp? noticia=147>. Acesso em: 9 ago. 2007.

181 "CDs were developed to replace vinyl with a better quality, more portable, and more durable product. When CDs came onto the market and everyone had to convert from vinyl to digital, it was an unprecedented boom time for the music industry. Though that boom was unsustainable over the long term, everyone enjoyed it, and many a record executive grew fat and complacent. No wonder: just crunk out the old stuff again, repackage it nicely, and take in another huge round of cash. This resulted in cementing drastic, unrealistic expectations in regards to future revenues. However, after almost twenty years, today the CD replacement cycle was ended. Yes, almost everyone did buy the same album twice. Why should the record companies expect that sales levels would remain the same or continue to increase?." (KUSEK e LEONHARD, The future of music..., p.82-83). 
Enfim, no Brasil, país considerado incontrolável em se tratando de pirataria física de CDs, agora se oferece o acesso às tecnologias digitais em rede ao público já acostumado a consumir produtos contrafeitos na sua forma física. Diante disso, será então possível pretender que passem a adquirir suas músicas mediante pagamento aos titulares? 


\section{CAPÍTULO 2}

\section{A ATUAL CRISE DOS DIREITOS AUTORAIS NA MÚSICA}

\subsection{INTERNET E DIREITOS AUTORAIS: NOTAS INTRODUTÓRIAS}

A definição de internet, exposta nos dicionários, é que se trata de uma "rede de computadores dispersos por todo o planeta que trocam dados e mensagens utilizando um protocolo comum, unindo usuários particulares, entidades de pesquisa, órgãos culturais, institutos militares, bibliotecas e empresas de toda envergadura" 182 .

A partir dessa concepção, é de se questionar se, nos dias atuais, a internet representaria algo puramente virtual, tão-somente um eficiente meio técnico-digital a existir em paralelo ao chamado "mundo real", ou então seria algo já entrelaçado ao cotidiano da coletividade, tendo ultrapassado a fronteira do virtual para daquela efetivamente se tornar parte indissociável?

Nesse sentido, a definição dos dicionários pode ser considerada reducionista por não refletir a fenomenal importância da internet à humanidade. É difícil mencionar algo ou alguém que pela "grande rede" não tenha sido atingido, direta ou indiretamente. Os sistemas governamentais, bancários, de telecomunicações e mesmo os relacionamentos interpessoais foram fortemente modificados após o desenvolvimento da rede, inicialmente concebida com fins militares, para evitar que os Estados Unidos ficassem isolados, no caso de um ataque nuclear ${ }^{183}$.

182 Cf. verbete "internet" do Dicionário Houaiss, disponível em: <http://houaiss.uol.com.br/busca.jhtm? verbete $=$ internet $\& \mathrm{x}=0 \& \mathrm{y}=0 \&$ stype $=\mathrm{k}>$. Acesso em: 19 mar. 2007. A rede internet é interligada por protocolos de comunicação TCP/IP, que dá transporta diversos aplicativos, em especial o "HTTP" (HyperText Transfer Protocol ou Protocolo de Transferência de Hipertexto, em vernáculo), que é o protocolo que faz funcionar sua face mais conhecida, a World Wide Web (WWW), bem como o FTP (File Transfer Protocol ou Protocolo de Transferência de Arquivos) e, no que muito interessa ao presente estudo, dá suporte a todos os aplicativos que fazem a transmissão de obras musicais, conforme será adiante objeto de análise.

183 Alexandre Freire Pimentel informa que "o modelo de computador 'mainframe', que ficava ao centro de um sistema como uma estrela do mar cujos tentáculos interligavam em cada extremidade 'terminais burros', noutras palavras, terminais que para processar determinada informação dependiam da 'inteligência' da máquina central, da 'estrela', já no ano de 1969, havia sido superado pelo conceito de rede telemática em que muitas máquinas inteligentes podem ser conectadas, de maneira a usufruírem de informações, compartilhando recursos, sem que, no entanto, nada mais fosse centralizado num único computador. E isso aconteceu quando o Departamento de Defesa dos Estados Unidos, no citado ano, criou a ARPAnet (Advanced Research Projects Agency - Agência de Projetos de Desenvolvimento Avançado), com a finalidade de evitar que um ataque nuclear fosse capaz de, uma vez destruindo os 
Ainda, pelo fato de a internet disseminar informação convertida em dados, portanto imaterial, na temática dos direitos autorais o impacto de seu uso foi mais intenso.

Na rede, as obras musicais são digitalizadas ${ }^{184}$, pois transformadas em bits $^{185}$ :

Em forma eletrônica, as obras protegidas pelo direito de autor analisam-se em seqüências de dígitos, tal como os programas de computador em código objecto. Isto é, em 'forma digital, uma obra é geralmente gravada (fixada) como uma seqüência de códigos binários (zeros e uns) utilizando meios especiais de codificação'. ${ }^{186}$

'mainframes', aniquilar todas as informações que os mesmos contivessem. (...) Com o fim da Guerra Fria, a rede, que mais tarde veio a receber o nome de Internet, teve seu acesso a partir de então disponibilizado para o público em geral". (PIMENTEL, Alexandre Freire. O direito cibernético: um enfoque teórico e lógico-aplicativo. Rio de Janeiro: Renovar, 2000. p.44-45).

184 Para detalhado histórico do roteiro da estrutura da música eletrônica, desde seu início (em 1937, com a guitarra elétrica) até a digitalização, vide BERTRAND, La musique..., p.25-35.

185 Extrai-se das aulas ministradas em 1974 pelo Professor italiano Mario G. Losano no Curso de Extensão Universitária realizado no Departamento de Direito Econômico Financeiro da Faculdade de Direito da Universidade de São Paulo que: "os termos caracteres binários traduzem o inglês 'binary digits'. Da aglutinação destas duas palavras nasceu o termo bit, que indica justamente o dígito binário. (...) Se o bit é a menor parte da informação, mas não tem significado, o byte é a menor parte significativa de um código EBCD. Um byte é composto, pois, de 8 bits e corresponde à dupla tétrade que caracteriza esse código". (LOSANO, Mario G. Lições de informática jurídica. São Paulo: Resenha Tributária, 1974. p.67). "O sistema binário é um sistema de numeração formado por apenas dois algarismos: 0 (zero) e 1 (um). Ou seja, só admite duas possibilidades, sempre antagônicas, como: tudo/nada; ligado/desligado; presença/ausência, direito/esquerdo, alto/baixo, verdadeiro/falso, aceso/apagado... Semelhante ao sistema de numeração arábico que usamos (que, quando se chega ao 9, retorna-se ao 0), no código binário quando se chega ao 1 volta-se ao 0 , já que o conjunto só possui dois algarismos. Os microprocessadores percebem somente sinais elétricos, distinguindo-os em dois níveis de voltagem: - nível alto, "high", H, correspondente a tensão elétrica alta, e - nível baixo, "low", L, tensão elétrica baixa. Portanto, qualquer comunicação com o microprocessador pode ser reduzida exclusivamente a esses dois sinais, asociando-se $\mathrm{H}$ com o bit 1 e L com o bit 0". (CONTI, Fátima. Muitas dicas. Disponível em: <http://www.cultura.ufpa.br/dicas/ progra/arq-cod.htm>. Acesso em: 5 maio 2007). Norbert Wiener explica o motivo da escolha do código binário: "a máquina de computação deve ser uma máquina lógica tanto quanto aritmética e devem combinar contingências de acôrdo com algum algoritmo sistemático. Embora haja inúmeros algoritmos que poderiam ser utilizados na combinação de contingências, o mais simples é conhecido como a álgebra da lógica par excellence, ou a álgebra de Boole. Este algoritmo, como a aritmética binária, baseia-se na dicotomia, a escolha entre o sim e o não, a escolha entre estar em uma classe e estar fora. As razões de sua superioridade sôbre outros sistemas são da mesma natureza que as da superioridade da aritmética binária sôbre outras aritméticas". (WIENER, Norbert. Cibernética; ou, contrôle e comunicação no animal e na máquina. Trad. Gita K. Ghinzberg. São Paulo: Polígono e Universidade de São Paulo, 1970. p.155-156). Uma curiosidade: o correspondente a "USP", em código binário, é "010101010101001101010000" e a "direito de autor" é "011001000110100101110010011001010110100 10111010001101111001000000110010001100101001000000110000101110101011101000110111101 $1100100000110100001010 "$. Aliás, não deixa de ser interessante saber que o equivalente a "01" é, em código binário: "0011000000110001". Existe um sítio na internet que oferece a "tradução", e pode ser acessado em <http://nickciske.com/tools/binary.php>. Acesso em: 5 maio 2007.

186 PEREIRA, Alexandre Dias. Música e eletrônica: "sound sampling", obras de computador e direitos de autor na internet. In: Direito da sociedade da informação. Coimbra: Coimbra Editora, 2004. p.318-319. Com a ressalva de que, conforme adiante será visto, não é unânime na doutrina o entendimento de que a gravação da obra em meio digital pode ser considerada fixação nos termos da legislação autoral. 
Boa parte do conteúdo disponível na internet é objeto de proteção pelos direitos autorais, o que fundamenta a necessidade de autorização de seus respectivos titulares para que lá seja utilizado.

No início da internet comercial, que ocorreu na primeira metade da década de 1990 nos Estados Unidos da América e em 1995 no Brasil, muitos a consideravam um mundo à parte ${ }^{187}$, um espaço livre de direitos ${ }^{188}$, sem a aplicação das leis estatais, mas tãosomente de um código de conduta baseado no bom-senso. Com isso, sob o pretenso anonimato proporcionado por um acesso efetuado a partir de sua residência, muitos dos usuários se entendiam inatingíveis, portanto aptos a praticar o que bem entendessem inclusive infringir direitos autorais.

Inevitável, pois, que severa tensão passasse a ter lugar na relação entre os direitos autorais e a nova mídia internet, já que obras de toda natureza (fotografias, textos, músicas e vídeos) passaram a ser transferidas de seus meios físicos (corpus mechanicum) para o meio virtual, mediante processos de digitalização que foram desenvolvidos e aprimorados ${ }^{189}$ com notável rapidez.

187 Nesse sentido, a "Declaração de Independência do Ciberespaço", escrita por John' Perry Barlow, fundador da EFF - Electronic Foundier Foundation disponível, em inglês, no sítio <http://homes.eff.org/ barlow/ Declaration-Final.html>. Acesso em: 5 maio 2007.

188 Informa José de Oliveira Ascensão que "uma corrente de origem norte-americana sustentou que o ciberespaço seria um espaço livre de direitos. Escaparia aos comandos do copyright, que não teriam sido estabelecidos em atenção a esse meio. No extremo oposto, outra corrente sustentou que o Direito Autoral abrangeria automaticamente todo o novo campo aberto pela informática. Só o meio mudava, mas isso seria juridicamente irrelevante. A utilização pela internet estaria assim sujeita ao Direito Autoral clássico, sem que este necessitasse de alterações" (ASCENSÃO, José de Oliveira. Aspectos jurídicos da distribuição em linha de obras literárias, musicais, audiovisuais, bases de dados e produções multimédia. In: Direito da sociedade da informação. Coimbra: Coimbra Editora, 2004. v.5. p.84-85).

189 Sobre a evolução e aprimoramento da linguagem computacional, noticia Alexandre Freire Pimentel que "a linguagem de máquina - baixo nível - fora substituída pela de montagem ou assembly, na primeira tentativa de aproximar a linguagem utilizada pelo computador com a humana. Os bits foram substituídos por palavras mnemônicas, ou seja, associando aquilo que deve ser memorizado com dados ou símbolos já conhecidos. A linguagem assembly, no entanto, apresenta vários dos problemas inerentes à linguagem de máquina, o que somente foi solucionado pelas linguagens avançadas ou de alto nível. As linguagens de alto nível conseguiram finalmente tornar-se independentes em relação ao hardware, viabilizando a utilização de um mesmo programa em diferentes equipamentos, através do uso de programas compiladores, prescindindo-se do conhecimento do hardware específico do equipamento" (PIMENTEL, Alexandre Freire. O direito cibernético: um enfoque teórico e lógico-aplicativo. Rio de Janeiro: Renovar, 2000. p.215-216). 
Naquele momento inicial, diversos sítios ${ }^{190}$ pessoais e comerciais deram início à utilização de fotografias sem os devidos créditos e muito menos remunerar o fotógrafoautor, assim como obras literárias passaram a ser reproduzidas sem autorização ${ }^{191}$. A infração passou a constituir a regra. O cenário que se delineou para os direitos autorais foi o mais sombrio possível.

Em relação à música, o tamanho dos arquivos que as continham era um problema, até mesmo porque as conexões de acesso à internet eram lentas, por linha discada, mas mesmo assim, havia quem, no período inicial, as digitalizasse e as disponibilizasse em seus sítios ${ }^{192}$, sem se preocupar com questões legais, assim como começaram a surgir, especialmente no exterior, diversas "rádios on-line" e os serviços de troca de arquivos.

O fato é que, em decorrência da característica global da internet ${ }^{193}$, criou-se a necessidade do aprofundamento das disciplinas jurídicas no acompanhamento das questões que se colocam, mesmo cotidianas, mas não mais em termos locais, porém mundiais, mormente aquelas relacionadas com direitos autorais.

190 Sítio = Website ou simplesmente site. "Na sua configuração mais simples, o website é a expressão de um conjunto de documentos e elementos digitais (scripts, bancos de dados associados, hiperlinks) que compõem o espaço virtual através do qual indivíduos e entidades disponibilizam informações, ofertam bens e serviços e se comunicam com o público em geral na Internet". (SANTOS, Manoel J. Pereira dos. A proteção autoral do website. Revista da ABPI - Associação Brasileira da Propriedade Intelectual, n.57, p.5, mar./abr. 2002).

191 Como exemplo, os trabalhos acadêmicos, que passaram a ser publicados e tornados disponíveis na rede como forma de possibilitar o mais amplo acesso ao conhecimento, então começaram a ser despudoradamente utilizados por alunos dos mais diversos níveis mediante simples cópia e alteração da autoria, como se sua própria fosse. Deu-se início ao hábito do "copia-e-cola" estudantil, que além de infringir direito moral e patrimonial de autor em muito prejudica a pesquisa.

192 Em opinião diversa, no sentido de que a obra musical digitalizada foi a primeira a explorar o ciberespaço, Deborah De Angelis, para quem "la musica è stata la prima tra le opere dell'ingegno ad esplorare il cyberespacio: infatti, una composizione musicale, tradotta in codice binario, si adatta facilmente ad essere trasmessa, racchiusa in un pacchetto di dati, sulle autostrade dell'informazione" (De ANGELIS, La tutela giuridica..., p.9).

193 "La musica è universale e tale circostanza si sposa perfettamente con la globalità delle comunicazioni della rete internet." (De ANGELIS, La tutela giuridica..., p.9). 


\subsection{A INTERNACIONALIZAÇÃO DO DIREITO AUTORAL NA MÚSICA}

Desde antes da Convenção de Berna já se buscava a internacionalização da proteção autoral, pela constatação de que a infração aos direitos intelectuais não respeitava fronteiras, fazendo com que diversos Estados firmassem acordos bilaterais sobre direito autoral no decorrer do século XIX nos quais, reciprocamente, estendiam aos cidadãos ou súditos do outro Estado a mesma proteção conferida aos seus ${ }^{194}$.

Em análise das modificações nas leis protetoras internas havidas por força das crises do direito autoral na música, constata-se que todas foram promovidas sob influência de tratado internacional do qual o Estado em questão foi parte e, até, conforme adiante será abordado, também em função de tratados dos quais não é signatário, mas acaba por voluntariamente inserir algumas das disposições lá contidas na sua legislação interna.

Desse modo, se por um lado a influência do direito internacional não constitui qualquer novidade aos sistemas de proteção dos direitos autorais, por outro é fato que o advento da sociedade da informação ${ }^{195}$, na qual se insere a internet, ampliou em muito os desafios de grande complexidade à disciplina do direito autoral.

No ciberespaço ${ }^{196}$, a facilidade com que os sujeitos passaram a transpassar fronteiras, mesmo que virtuais, certamente representa um problema muito maior do que aqueles passíveis de serem resolvidos na esfera interna de cada país, em razão dos correspondentes

194 Informa Michael Blakeney que os primeiros acordos bilaterais foram firmados entre a Prússia e 32 estados alemães, no período entre 1827 e 1829 e que na metade do século XIX Grã-Bretanha e França firmaram acordos bilaterais de direito de autor com a maioria dos Estados europeus (BLAKENEY, Michael. The international protection of industrial property: From the Paris Convention to the TRIPS agreement. Cairo: OMPI, 2003. p.8).

195 Na lição de José de Oliveira Ascensão, a sociedade da informação "seria a sociedade de comunicação total, resultante de um diálogo de todos, de modo que cada um apareceria como um comunicador também. E a sociedade em que cada um teria, pelos meios digitais, um acesso quase ilimitado à informação". Para o autor, a sociedade da informação é um resultado do objeto "veículos multimédia" com o veículo "auto-estradas da informação". (ASCENSÃO, José de Oliveira. Os direitos de autor no domínio das telecomunicações. In: Coimbra: Almedina, 2001. p.71). . Estudos sobre direito da internet e sociedade da informação.

196 Para Alexandre Dias Pereira, ciberespaço "é o produto da convergência tecnológica da informática, das telecomunicações e do audiovisual. Convergência essa que, por seu turno, é possibilitada pela linguagem binária da informática". (PEREIRA, Informática, direito..., p.18). Segundo Omar Kaminski: "A invenção da palavra cyberspace é atribuída ao escritor de ficção-científica norte-americano William Gibson, em sua obra "Neuromancer", de 1982. Gibson utilizou o termo para definir uma rede de computadores futurista, utilizada conectando-se a mente diretamente a ela. Um mundo virtual, não tangível, paradoxal; algo como um céu onde cada estrela representa um foco de atividade. Ambiente esse 'contido' na Internet, e não sinônimo desta." (KAMINSKI, Omar. A internet e o ciberespaço. Disponível em: $<\mathrm{http}$ //buscalegis.ccj.ufsc.br/arquivos/a14-internetC.htm>. Acesso em: 6 maio 2007). 
ilícitos trans-fronteiriços cometidos. Ao mesmo tempo em que, com a tecnologia, são apresentadas soluções de problemas caracterizados por notável complexidade, outros são criados ${ }^{197}$.

A grande questão é que, em vista das diferentes sociedades e culturas que preenchem o globo terrestre, atos que são perfeitamente lícitos em um país podem constituir ilícitos graves em outro (e muitas vezes efetivamente o são). Daí porque o direito internacional passou a ter, nos tempos atuais, grande papel no auxílio da resolução dos problemas advindos do caráter transnacional da internet ${ }^{198}$.

Nesse contexto, surgem as tentativas de minimizar os problemas gerados pelo atrito entre diferentes sistemas sociais e, por conseqüência, diferentes sistemas jurídicos. $\mathrm{Na}$ atualidade é amplamente defendida a harmonização ${ }^{199}$ das normas de proteção aos direitos autorais, pela União Européia e pelos governos dos países que adotam o sistema do direito de autor continental, enquanto o governo dos Estados Unidos da América acompanhado pelos titulares de direitos autorais -, notadamente as gravadoras - defende a uniformização 200 .

Por meio da Diretiva 2001/29/CE do Parlamento Europeu e do Conselho, de 21 de maio de 2001, relativa à harmonização de certos aspectos do direito de autor e dos direitos conexos na sociedade da informação, a União Européia declaradamente se pôs partidária da harmonização, sob a justificativa de que

197 É o que aponta Victor Uckmar, sob o enfoque do fluxo internacional de capitais, reportando-se ao relatório do Fundo Monetário Internacional - FMI denominado "Liberalizing Capital Movements, 1999", onde consta que "revolutionary change in information and communications technologies have transformed the financial services industries world-wide. Computer links enable investors to access information on asset prices at minimal cost on a real-time bases, while increased computing power enables them to rapidly calculate correlations among asset prices and between asset prices and other variables. At the same time, new technologies make it increasingly difficult for governments to control either inward or outward international capital flows when they wish to do so." (UCKMAR, Victor. Introduzione. In: __ Corso di Diritto Tributário Internazionale. II edizione. Padova: CEDAM, 2002. p.10).

198 São diversos os estudos que analisam questões concernentes à globalização, no que diz respeito à sociedade da informação, com a propositura de diversas soluções, inclusive com a defesa da aplicação da legislação internacional aplicável ao espaço sideral ao ciberespaço, cf. BALSANO, Anna Maria. An International Legal Instrument for Cyberspace? A Comparative Analysis with the Law of Outer Space. In: International Dimensions of Cyberspace Law. Paris: UNESCO, 2000.

199 A harmonização busca a aproximação das regras de diferentes países, enquanto a uniformização busca a adoção das mesmas regras.

200 Entretanto, a tal interesse na uniformização só se daria mediante a adoção da legislação estadunidense pelos outros Estados, e não o contrário. 
a presente directiva visa adaptar a legislação relativa ao direito de autor e aos direitos conexos à evolução tecnológica e mais especificamente à sociedade da informação. O objectivo é transpor a nível comunitário as principais obrigações internacionais decorrentes dos dois Tratados em matéria de direito de autor e direitos conexos, adoptados em Dezembro de 1996, no âmbito da Organização Mundial da Propriedade Intelectual (OMPI). ${ }^{201}$

Note-se que as leis internas dos países que seguem o mesmo sistema de proteção aos direitos autorais, notadamente o do direito de autor e o de copyright, já são entre si harmonizadas, em vista da tradicional divisão em correspondentes blocos, nas negociações dos tratados e nas assinaturas ou recusas a tal. Assim, grande dilema trazido pelo digital é a busca da conformação legislativa entre os distintos sistemas.

Para José de Oliveira Ascensão:

Nota-se uma progressiva aproximação dos sistemas mundiais de protecção, com o estabelecimento de pontes entre eles. Particularmente, essa aproximação verifica-se com o sistema de copyright. A harmonização (e não uniformização) dos sistemas é benéfica para todos. Deve por isso ser saudada como um verdadeiro progresso. Sendo assim, toda a rigidez em posições incompatíveis é inconveniente. ${ }^{202}$

É nesse sentido, da harmonização, que deve caminhar a proteção dos direitos autorais $^{203}$, buscando-se o equilíbrio entre a defesa dos autores (caso do direito de autor continental) ou do investidor ${ }^{204}$ (caso do copyright) com o devido respeito às particularidades socioculturais dos povos dos diversos Estados 205 .

201 Disponível em: <http://europa.eu/scadplus/leg/pt/lvb/126053.htm>. Acesso em: 7 jun. 2007.

202 ASCENSÃO, José de Oliveira. Convergências de tecnologias: perspectivas jurídicas. In: Direito da sociedade da informação. Coimbra: Coimbra Editora, 2004. v.5. p.93.

203 Deborah De Angelis parte do entendimento de que está a ocorrer a uniformização, para quem "attualmente, $i$ diversi sistemi giuridici di diritto d'autore moderno si stanno necessariamente uniformando grazie sia all'operato delle convenzioni internazionali, sia al trend della 'globalizzazione', che invade l'area del diritto e delle relazioni commerciali. Oggi un'adeguata tutela del diritto d'autore, di fronte alla deterritorialità propria del mondo virtuale di Internet, non ammette discrepanze di disciplina tra $i$ diversi Stati del globo, tutti coinvolti in una relazione di rete" (De ANGELIS, La tutela giuridica..., p.88).

204 Em sentido contrário ao caráter empresarial da proteção no sistema do copyright, José de Oliveira Ascensão: "Mas não se pode confundir o Direito Autoral com a protecção dos investimentos. O Direito Autoral não é o instrumento idôneo para proteger investimentos. Não se pode pregar um direito cujo elevadíssimo nível de protecção é fundado no carácter nobre da criação intelectual e aplicá-lo depois à protecção empresarial. A actividade empresarial deve ter os seus próprios instrumentos de protecção". (ASCENSÃO, Convergências de tecnologias..., p.92).

205 É justamente em observância ao caráter dinâmico dos povos historicamente demonstrado que Pontes de Miranda se demonstra contrário à rígida uniformização: "a história, aí, é quási tudo; mas, se a indagação deixar de apreender o que de longe vem a formar-se, se não atende ao que a justiça internacional está a confirmar do passado multiforme (dura, no tempo, o que se escolheu), perde todo o valor científico, 
São diplomas ativos do direito internacional que versam sobre a proteção dos direitos autorais na música, administrados pela OMPI (Organização Mundial da Propriedade Intelectual): a "Convenção de Berna para a Proteção de Obras Literárias e Artísticas", de 1886, com a vigente revisão de Paris, de 1971; a "Convenção de Roma para a Proteção dos Intérpretes, Produtores e Organismos de Radiodifusão", de 1961; a "Convenção de Genebra para a Proteção dos Produtores de Fonogramas Contra Duplicações NãoAutorizadas de seus Fonogramas", de 1971; a "Convenção de Bruxelas Relativa à Distribuição de Sinais Portadores de Programas Transmitidos por Satélite", de 1974; e os chamados tratados da internet: o Tratado OMPI de Direitos Autorais e o Tratado OMPI de Interpretações e Fonogramas, ambos de 1996.

A OMC - Organização Mundial do Comércio, por sua vez, administra o tratado TRIPS - Trade-Related Aspects of Intellectual Property Rights (ou Aspectos da propriedade intelectual relacionados com o comércio), primeiro acordo multilateral sobre comércio que incluiu disposições sobre propriedade intelectual, negociado na rodada do Uruguay, entre os anos de 1988 e 1994.

O Brasil é parte signatária dos tratados acima, à exceção dos tratados da OMPI, de 1996, muito embora perceba-se na lei autoral brasileira de 1998 a adoção de diversas das inovações por meio deles introduzidas, em especial aquelas relacionadas às novas tecnologias.

\subsection{O PARADIGMA DIGITAL: APROFUNDAMENTO DA INTANGIBILIDADE DO BEM IMATERIAL}

Da doutrina clássica do direito de autor se extrai a concepção de que a obra (corpus misticum) deve ser fixada em um suporte material (corpus mechanicum)206, "salvo

porque reduz a estático o que é, por definição, dinâmico. Que a história, em nossa disciplina, seja a bússola, como queria Josef Kohler, coisa é de que ninguém deve duvidar; todavia, o fim da viagem não é empregar a bússola: é navegar para conhecer, e conhecer para resolver". (PONTES DE MIRANDA. Francisco Cavalcanti. Tratado de direito internacional privado. Rio de Janeiro: José Olympio, 1935. Tomo I. p.127-128).

206 "Nos meios de comunicação tradicionais, o direito de autor assenta no princípio de que as obras podem ser fixadas e reproduzidas num suporte comunicativo e assim permanecem. Porém, em suporte electrónico a obra passa a ser marcada pela 'plasticidade', estando em causa o problema da sua unidade. Por outras palavras, tradicionalmente a tangibilidade dos suportes tradicionais dos exemplares da obra colocava obstáculos à sua transformação. Agora, em suporte electrónico, as obras tornam-se 'plásticas' por sua natureza, isto é, podem ser facilmente transformadas de uma forma para outra, ou alteradas. Esta problemática chegou a pôr em causa a noção de obra como objecto do direito de autor. Não obstante, concordamos com o entendimento segundo o qual 'só por si, o facto de que a digitalização permite 
nos casos em que oral é a comunicação, quando se identifica e se exaure, no mesmo ato, a criação (aula, conferência, palestra, discurso, dança, mímica e outras)"207. Até então, a grande questão que permeava tal divisão entre obra e seu suporte físico era evitar o entendimento de que a aquisição da propriedade de exemplar da obra significava a propriedade da própria obra, previsão que já constava da norma ${ }^{208}$ e que, nas palavras de José Oliveira Ascensão 209 :

Já com a doutrina alemã do dobrar do século o ponto ficou definitivamente adquirido. $\mathrm{O}$ que se protege não é a obra incarnada mas a obra imaterial: não o livro, mas o texto, se assim nos podemos exprimir, que este contém. O que significa que toda a obra é imaterial; e a imaterialização trazida pelo âmbito digital não contradiz em nada a essência do direito de autor.

Aprofundando o tema, Mario Are aponta que a possibilidade de identificação e determinação dos bens imateriais a serem tutelados pelo direito de autor se manifesta somente de modo indireto, mediante os meios físicos de exteriorização perceptíveis aos sentidos ${ }^{210}$, os quais o autor divide em meios corpóreos, compostos de matéria sólida e manifestações

formatos unitários para obras diferentes, tal como a compressão de dados permite a combinação de diversas obras, tal não pode conduzir a pôr de parte a obra como fundamento de protecção do direito de autor"' (PEREIRA, Alexandre Dias. Música e electrónica: "sound sampling", obras de computador e direitos de autor na internet. In: Direito da sociedade da informação. Coimbra: Coimbra Editora, 2004. v.5. p.318). O autor português demonstra sua concordância com o exposto por Gerhard Schricker et al. (SCHRICKER, Gerhard (Hrsg.) Urheberrecht auf dem Weg zur Informationsgesellschaft. Baden-Baden: Nomos, 1997. p.31).

207 BITTAR, Curso de direito autoral, p.25.

208 O entendimento de que a compra de um exemplar de obra intelectual não transferia ao comprador qualquer titularidade ou pretensão autoral já constava do primeiro diploma autoral do Brasil, a Lei n. ${ }^{\circ}$ 496/1898, chamada "Lei Medeiros e Albuquerque": "Art. 5. ${ }^{\circ}$ A cessão ou herança, quer dos direitos de autor, quer do objecto que materialisa a obra de arte, litteratura ou sciencia, não dá o direito de a modificar, seja para vendel-a, seja para exploral-a por qualquer fórma" e, ainda, "Art. 17. A cessão de um objecto de arte não implica a cessão do direito de reproducção em favor de quem o adquire, não podendo, porém, o artista reproduzil-o sem declaração de que não é o trabalho original". Tal disposição foi mantida em todas as leis autorais posteriores, com exceção do que apontou Eduardo Vieira Manso, em relação ao que chamou de "inusitada e isolada redação" do art. 80 da Lei n. ${ }^{\circ}$ 5.988/73: "Art. 80. Salvo convenção em contrário, o autor de obra de arte plástica, ao alienar o objeto em que ela se materializa, transmite ao adquirente o direito de reproduzí-la, ou de expô-la ao público", onde a ausência do vocábulo "não" antes da palavra "transmite" alterava o sentido do artigo, dando a entender que a venda do corpus mechanicum transferia a propriedade do corpus mysticum (MANSO, Direito autoral..., p.379-382). Tal distorção foi devidamente corrigida na Lei n. ${ }^{\circ}$ 9.610/98.

209 ASCENSÃO, José de Oliveira. Novas tecnologias e transformação do direito de autor. In: Estudos sobre direito da internet e sociedade da informação. Coimbra: Almedina, 2001. p.122.

210 "Per le entità immateriali, invece, la possibilità di identificazione e determinazione del bene tutelato, si manifesta solo in via indiretta attraverso quei mezzi fisici di estrinsecazione che ne consentono la percettibilità con i sensi." (ARE, L'oggetto del diritto..., p.217-218). 
energéticas, fundadas na percepção das ondas sonoras e luminosas ${ }^{211}$, ao mesmo tempo em que alerta para o fato de que a obra musical pode prescindir totalmente de qualquer modelo de realidade física, o que não quer dizer que ela não possa ser expressada ${ }^{212}$.

Nesse sentido, já na Lei de 1973, a proteção à obra musical era conferida à sua "exteriorização"213, e foi ampliada na Lei n. ${ }^{\circ}$ 9.610/98, sendo tal vocábulo da Lei anterior explicitado pelo seu conteúdo: a "expressão" e a "fixação". Ao mesmo tempo, houve ampliação, já que a norma passou a expressamente abranger as inovações tecnológicas, pela previsão da fixação em "suporte tangível ou intangível, conhecido ou que se invente no futuro"214.

A criação musical é dividida em várias etapas. Desde a concepção inicial do compositor $^{215}$ até a sua publicação existe um longo caminho a ser cumprido, com uma série de processos que podem tanto envolver expressões quanto fixações ${ }^{216}$.

211 "I mezzi fisici di estrinsecazione o di comunicazione consistono in mezzi corporei (libro, quadro, statua), composti cioè di materia solida (carta, tela e colori, marmo ecc.), ovvero in manifestazioni energetiche (discorso, recitazione, esecuzione) fondate sulla percettibilità delle onde sonore e luminose." (ARE, L'oggetto del diritto..., p.218).

212 "Non si deve confondere, infatti, l'attitudine dell'opera musicale a prescindere totalmente da ogni modello della realtà fisica (...) con la sua presunta incapacità di esprimerla." (ARE, L'oggetto del diritto..., p.370).

213 Lei n. ${ }^{\circ}$ 5.988/73: "Art. $6{ }^{\circ}$ São obras intelectuais as criações do espírito, de qualquer modo exteriorizadas, tais como: V - as composições musicais, tenham, ou não, letra."

214 LDA: "Art. 7. ${ }^{\circ}$ São obras intelectuais protegidas as criações do espírito, expressas por qualquer meio ou fixadas em qualquer suporte, tangivel ou intangível, conhecido ou que se invente no futuro, tais como: $\mathrm{V}$ - as composições musicais, tenham ou não letra."

215 Mario Are divide em três os elementos da obra musical: melodia, harmonia e ritmo. A melodia funda-se na sucessão de sons; a harmonia baseia-se em suas fusões; o ritmo constitui-se dos intervalos nos quais os próprios sons se sucedem. "Nell'ambito dell'opera musicale si distinguono tre elementi fondamentali: la melodia fondantesi sulla successione di suoni; l'armonia basata sulla loro fusione; il ritmo costituito dagli intervali con cui i suoni stessi si succedono." (ARE, L'oggetto del diritto..., p.377). Adverte, porém, o mesmo autor, que esta definição apresenta, na prática, alguma complexidade, cuja análise, entretanto, foge do escopo do presente estudo.

216 Pedro Vicente Bobbio bem resumiu o processo de composição musical, em tempos passados: "a sua primeira extrinsecação consiste, em geral, na fixação das suas linhas essenciais, apta, portanto, a ser apreciada por quem esteja iniciando à grafia musical, mas ainda inidonea à comunicação ao público. Essa primeira fixação é, sucessivamente, elaborada, para que a música possa ser tocada pelo menos por um instrumento; é ampliada para a execução orquestral, de pequena ou grande orquestra; ou para canto com acompanhamento, e assim por diante. Chegada a esse ponto, a composição musical está pronta para ser levada em contato com o público, mediante a sua execução. Ao mesmo tempo, pode ser dada à publicidade através da edição. Mas toda edição, embora reproduza a obra, é apenas um processo intermediario, destinado a fixar os sinais identificativos da musica (edição grafica, litográfica etc. da partitura) ou, então, a sua propria expressão sonora (registração em discos etc.) em "corpora mechanica" que, postos à venda, servirão aos adquirentes para, com o auxílio de instrumentos proprios (instrumentos musicais, gramofones etc.) apreciarem a música, ouvindo-a" (BOBBIO, $\mathbf{O}$ direito de autor..., p.17). 
Para Pedro Vicente Bobbio: "é que a música, destinando-se ao sentido auditivo, não pode, em tese, dispensar processos intermediários, cuja finalidade é, justamente, o de permitir a realização do pensamento criador na sua forma sonora, isto é, instantânea e fugitiva"217. Entretanto, constata-se que atualmente, mais de cinco décadas depois da publicação da importante obra de tal autor, com o advento das novas tecnologias, muitos dos processos da composição musical foram alterados ou mesmo suprimidos 218 .

Assim, no caso da música, a proteção autoral conferida pela lei se dá por diversas formas, tanto de expressão quanto de fixação ${ }^{219}$. Entretanto, mesmo com tal previsão normativa, por muito tempo perdurou ${ }^{220}$, e ainda perdura em grande parte da doutrina, o entendimento

217 BOBBIO, O direito de autor..., p.16.

218 Um microcomputador de uso doméstico contendo um dos muitos aplicativos disponíveis no mercado é uma ferramenta de extremo poder, que muitas vezes complementa e até substitui o fator humano na criação musical, o que certamente causa repercussão no âmbito do direito de autor. Questiona o português Alexandre Dias Pereira em artigo publicado em obra coletiva se "poderá um computador, utilizando um poderoso sistema de inteligência artificial, vir um dia a ser considerado autor de uma obra musical para efeitos de protecção pelo direito de autor", para ele mesmo responder, em monografia que "para além das obras geradas por computador, a própria criação humana é alterada no que respeita às suas condições, sendo de destacar que as obras serão cada vez menos criadas pelos autores em termos de plena autonomia" (PEREIRA, Música e eletrônica..., p.314) e que "os programas que podem gerar automaticamente outras obras colocam um problema delicado ao direito de autor, principalmente porque este instituto repousa no princípio dogmático segundo o qual as obras susceptíveis de protecção são criadas por pessoas humanas. Apesar de a automação do processo de produção destas obras significar que não lhes podem ser designados autores humanos, é difícil negar, sem mais, a concessão de direitos por causa do valor comercial que a obra gerada automaticamente pode ter". Conclui o mesmo autor que "na concepção do droit d'auteur dos sistemas de Civil Law o requisito da originalidade obsta a que as obras geradas por computador sejam protegidas pelo direito de autor" (PEREIRA, Informática, direito..., p.406, 408-409), opinião compartilhada pelo conterrâneo José de Oliveira Ascensão, para quem "o computador, por meio de programas adequados, pode produzir 'obras' no sentido de resultados objectivamente apreciáveis de carácter literário ou artístico. Uma vez que esses resultados não são antecipadamente previsíveis na sua individualidade, é impossível considerar o autor do programa de computador como o autor dessas obras" e que o direito de autor romanístico "exige uma intervenção inovadora do espírito humano fundada na criatividade". (ASCENSÃO, José de Oliveira. Direito de autor e informática jurídica. In: Coimbra: Almedina, 2001. p.13).

Estudos sobre direito da internet e sociedade da informação.

219 "De todas as creações inteletuais, a musical é a que da lugar ao maior numero de especificações do direito autoral, no campo dos direitos de reprodução, ou explorativos ou patrimoniais." (BOBBIO, O direito de autor..., p.16)

220 É emblemática a opinião de Antonio Chaves, para quem "não pode, no entanto, a obra musical atingir sua finalidade última, que é a de ser executada ou representada, a não ser que aos artistas executantes seja proporcionado o meio pelo qual lhes seja permitido ler e aprender o texto". (CHAVES, Direito do autor, p.440). 
de que a obra musical não prescinde da fixação, muito embora houvesse o reconhecimento de que o direito de execução, forma de expressão, era o mais importante ${ }^{221}$.

Sobre o tema, Mario Are disserta que 222 :

\begin{abstract}
A música, com efeito, não é uma seqüência de sinais escritos, mas uma série de sons. Tem-se depois a substituição de um meio, definitivo como instrumento de fixação do conteúdo intelectual, mas inidôneo ao gozo do mesmo elemento em sua perceptível forma própria, por outro instrumento, que é definitivo também na expressão perceptível. A obra, por outro lado, existe desde a criação do primeiro meio no qual é fixado o elemento intelectual. (...) Igualmente é indiferente, enfim, que o suporte em si se preste a um gozo direto da obra, quer dizer, constituído de uma matriz, de um molde, de um negativo ou de outros meios destinados unicamente à produção de exemplares.
\end{abstract}

Na obra musical, a forma de exteriorização corpórea se dava, no início, pelas das partituras; depois com o cilindro do fonógrafo; com o disco do gramofone; com o Long Play de vinil; com a fita-cassete e, recentemente, com o Compact Disc. À noção de obra estava umbilicalmente ligado o meio físico, já que se podia manuseá-lo.

Tal noção foi positivada mediante a construção normativa do direito internacional, introduzida pela "Convenção de Roma para a Proteção dos Intérpretes, Produtores e Organismos de Radiodifusão", de 1961, no sentido de que a fixação da obra musical seria denominada "fonograma", mandamento que foi inserto na Lei n. ${ }^{\circ}$ 5.988/73:

Art. 4. ${ }^{\circ}$ Para os efeitos desta lei, considera-se:

VII - fonograma - a fixação, exclusivamente sonora, em suporte material.

A partir da Convenção de Roma foram assegurados direitos conexos ao autoral ao produtor de fonogramas, sendo que seus países-parte trataram de incluir em seus regramentos

221 "Evidente, portanto, que o contato do público com a creação musical é feito através da execução, isto é através da expressão sonora, destinada ao sentido auditivo. Todos os demais processos reprodutivos da música são exclusivamente preparatorios da execução, na qual consiste, essencialmente, a manifestação do pensamento creador. Eis a razão pela qual (...) o direito de execução é o mais importante de todos os direitos do musicista e deve ser defendido com maior empenho, tanto no campo teorico juridico, como no terreno pratico e patrimonial." (BOBBIO, O direito de autor..., p.17). No mesmo sentido, Mario Are: "La partitura musicale, può essere letta infatti da chiunque conosca le note, ma l'opera musicale assume la sua veste definitiva solo con l'esecuzione." (ARE, L'oggetto del diritto..., p.220).

222 Tradução, pelo autor, de "La musica, infatti, non è una sequenza di segni scritti, ma una serie di suoni. Si ha quindi la sostituzione di un mezzo, definitivo come strumento di fissazione del contenuto intellettuale, ma inidoneo al godimento dell'elemento medesimo nella sua forma sensibile propria, con altro strumento, che è definitivo anche nella veste sensibile. L'opera peraltro esiste già con la creazione del primo mezzo in cui è fissato l'elemento intellettuale. (..). Del pari è indifferente, infine, che il supporto stesso si presti ad un godimento diretto dell'opera, ovvero sia costituito da una matrice, da un calco, da un negativo o da altri mezzi destinati unicamente alla produzione di esemplari." (ARE, L'oggetto del diritto..., p.220-221). 
disposições que contemplassem o lá contido. Assim, a relação de poder entre compositores, intérpretes e indústria fonográfica foi substancialmente alterada. De relação de natureza contratual operada entre as partes - entretanto já com relato de exercício abusivo de posição contratual -, a lei passou a reconhecer às gravadoras um status diferenciado, o que ampliou ainda mais a dominação e a distorção sempre existentes entre o lucro do investidor e a remuneração dos autores e dos intérpretes.

Note-se, nesse sentido, que a proteção da obra musical passou a ser nivelada com o fonograma, sua mera fixação, o que pode ser atribuído a uma falha da Lei n. ${ }^{\circ}$ 5.988/1973, a qual preconizava que:

Art. 94. As normas relativas aos direitos do autor aplicam-se, no que couber, aos direitos que lhes são conexos.

Muito embora houvesse a expressão "no que couber", o entendimento das representantes da indústria fonográfica era de que "tudo cabia", pois chegaram a propor ações, em nome próprio, nas quais pleiteavam a indenização e o reconhecimento de direitos morais em seu favor, da mesma forma que, no trato profissional com os compositores e intérpretes, a si atribuíam igual patamar de direitos.

Tal distorção da Lei anterior, que contrariava frontalmente o artigo primeiro da Convenção de Roma, felizmente foi corrigida na Lei atual, de 1998, com a inclusão de parágrafo:

Convenção de Roma para a Proteção dos Intérpretes, Produtores e Organismos de Radiodifusão

Artigo Primeiro

A proteção prevista pela presente Convenção deixa intacta e não afeta, de qualquer modo, a proteção do direito de autor sobre as obras literárias e artísticas. Deste modo, nenhuma disposição da presente Convenção poderá ser interpretada em prejuízo dessa proteção.

Lei n. ${ }^{\circ} 9.610 / 98$

Art. 89. As normas relativas aos direitos de autor aplicam-se, no que couber, aos direitos dos artistas intérpretes ou executantes, dos produtores fonográficos e das empresas de radiodifusão.

Parágrafo único. A proteção desta Lei aos direitos previstos neste artigo deixa intactas e não afeta as garantias asseguradas aos autores das obras literárias, artisticas ou cientificas.

Em relação aos fonogramas, para dar abrangência às inovações tecnológicas e atualizar o dispositivo da Lei de 1973, que previa tão-somente a fixação em suporte 
material, a Lei n. ${ }^{\circ}$ 9.610/98 apresentou a seguinte modificação, que fez excluir do texto legal a necessidade da fixação da obra em suporte material:

Art. 5. ${ }^{\circ}$ Para os efeitos desta Lei, considera-se:

IX - fonograma - toda fixação de sons de uma execução ou interpretação ou de outros sons, ou de uma representação de sons que não seja uma fixação incluída em uma obra audiovisual.

Tudo isso se passou de forma espantosamente rápida. Muito embora houvesse, na doutrina e na lei, o reconhecimento da expressão de obra musical como forma passível de proteção, o meio físico, material, era tido como indispensável ao processo musical, de uma forma ou de outra. Entretanto, em defesa dos doutrinadores autoralistas da escola clássica, nem eles nem tampouco os mais fantasiosos autores de ficção científica poderiam prever a revolução que viria com o advento da digitalização e da internet.

O bem tutelado pela propriedade intelectual, que já era intangível, tornou-se ainda mais imaterializado no digital, sem qualquer forma de contato manual com o suporte físico. Passou a ser fixado em arquivos digitais, seqüência de códigos binários, armazenados em lugares desconhecidos, muitas das vezes de forma temporária ${ }^{223}$, já que com a mesma facilidade que se introduzem em determinada memória podem ser apagados.

De outra sorte, a atualização normativa promovida realmente era necessária, uma vez que o requisito contido na legislação de 1973, no sentido de que o suporte fosse material, poderia causar discussões acerca da tangibilidade do meio digital224.

Alerta Alexandre Dias Pereira que "o novo paradigma tecnológico instituído pelos computadores digitais, numa palavra, pela informática, é o elemento dominante; não apenas integra os meios tradicionais mas também altera-lhes a natureza, imprimindo-lhes

223 No mesmo sentido, Eduardo Lycurgo Leite: "Em uma obra digital, não há fixação, pelo menos de forma permanente, como na obra fixada analogicamente, pois um texto digital (aqui utilizado no sentido amplo para expressar uma obra) possui como característica a maleabilidade, sendo, portanto, vulnerável. Assim poderíamos dizer que na obra digital a fixação é temporária, até que a mesma seja alterada". (LEITE, Eduardo Lycurgo. Direitos autorais nas mídias digitais. Revista da ABPI - Associação Brasileira da Propriedade Intelectual, n.49, p.13, nov./dez. 2000). O mesmo autor alerta para o fato de que, com a digitalização, obras das mais diversas categorias poderão ser combinadas, o que originará uma obra de difícil classificação, acarretando uma maior dificuldade normativa em regulá-las e protegê-las.

224 É o que questiona o autor português Alexandre Dias Pereira, se os atos de transmissão de obras entre sistemas informáticos em rede são reprodução, comunicação ao público ou distribuição, pelo que responde: "a qualificação de tais actos por meios eletrónicos é dificultada, uma vez que às categorias de fixação e reprodução parece faltar a durabilidade e a corporalidade do suporte, o mesmo valendo para a distribuição, relativamente aos exemplares". (PEREIRA, Música e eletrônica..., p.315). 
um carácter novo"225 e que "a distinção tradicional do direito de autor entre exploração corpórea e incorpórea é, assim, posta em causa no ambiente digital, como resulta, aliás, das dificuldades postas pela qualificação dos actos necessários à visualização de uma obra no ecrã de um computador"226.

Parece claro, entretanto, que muito embora não haja a possibilidade de manusear fisicamente o suporte da obra, que ela, ou melhor, seus bits encontram um meio de fixação, que seria a memória do computador, a qual fisicamente existe, de modo que pode ter havido um aprofundamento da intangibilidade, mas não a ausência da fixação, que sempre acaba por ocorrer, já que o virtual necessariamente precisa de um suporte.

É essa a inteligência do art. 5. ${ }^{\circ}$, VI da Lei n. ${ }^{\circ}$ 9.610/98:

Art. 5. ${ }^{\circ}$ Para os efeitos desta Lei, considera-se:

VI - reprodução - a cópia de um ou vários exemplares de uma obra literária, artística ou científica ou de um fonograma, de qualquer forma tangível, incluindo qualquer armazenamento permanente ou temporário por meios eletrônicos ou qualquer outro meio de fixação que venha a ser desenvolvido.

Depreende-se, assim, que a lei estatui o armazenamento permanente ou temporário como uma forma tangível de meio de fixação.

É de se ressaltar, também, o fato de que com a tecnologia digital a cópia é exatamente igual ao original, e, ainda, que a reprodução da cópia é exatamente igual ao original $^{227}$, e assim por diante, o que cria uma situação interessante, da dificuldade em se determinar qual é o original e, portanto, em saber qual seria a famosa "cópia máster", tão importante no sistema do copyright. No filme "Ray", sobre a vida de Ray Charles, existe uma cena em que se expõe que a exigência principal para mudar de gravadora foi manter

225 PEREIRA, Alexandre Dias. Direitos de autor, da imprensa à internet. Revista da ABPI - Associação Brasileira da Propriedade Intelectual, n.64, p.26, maio/jun. 2003.

226 PEREIRA, Informática, direito..., p.411. Segundo o autor, "parece, assim, afirmar-se uma tendencial equiparação entre a exploração material e a exploração imaterial das obras nas redes digitais informáticas. Com efeito, sob forma digital, quer tenha sido originariamente criada sob forma digital ou posteriormente digitalizada, torna-se praticamente irrelevante, pelo menos de um ponto de vista econômico, que a distribuição da obra se processe mediante um suporte material (por ex., um CD-ROM) ou através de uma rede de computadores, ou, ainda, através de sinais hertzianos por satélite".

227 Para Alexandre Dias Pereira: "um dos maiores desafios que a tecnologia digital coloca ao direito de autor tem a ver com a facilidade e o baixo custo com que podem ser feitas múltiplas cópias e distribuídas sob a forma digital, em especial no ambiente digital dos sistemas informáticos em rede, com a agravante de as cópias serem réplicas perfeitas do original". (PEREIRA, Música e eletrônica..., p.327). 
consigo a matriz, fixação original de suas obras, o que lhe conferia automaticamente a plena titularidade sobre suas obras.

Para Maria Victoria Rocha ${ }^{228}$ :

\begin{abstract}
A digitalização confunde a distinção tradicional entre serviços e produtos, fazendo convergir as indústrias de média, em que se contam a imprensa escrita e a indústria discográfica, que na fase pré-digital criaram produtos físicos, vendidos ao público através de redes clássicas de distribuição por grosso e a retalho, e as indústrias de difusão e as telecomunicações que produzem serviços, em sistema de monopólio ou oligopólio, controlando escassos canais de distribuição. Não quer dizer que o mercado dos suportes materiais desapareça por completo, mas o suporte deixa de ser o único meio de consumir livremente certo tipo de obras.
\end{abstract}

Tal questão é bem colocada pela autora portuguesa e demonstra a transformação pela qual a música está passando. De serviço que era nos primórdios, pelas execuções ao vivo que eram tiradas pelos intérpretes, passou a constituir produto elaborado pela indústria fonográfica e vendido em diversos formatos físicos e, agora, perspectiva-se um retorno ao serviço, conforme será adiante defendido no capítulo terceiro.

O fato é que as músicas digitalizadas passaram a ser facilmente obtidas pela internet, pois não somente sítios especializados como, principalmente, os usuários passaram a entre si trocar suas faixas musicais; não mais fisicamente, como antes faziam ao trocar fitas ou mesmo CDs gravados, mas sim seqüências de bytes, o que aprofundou o caráter imaterial da música e da intangibilidade do bem imaterial correspondente à obra musical. Isso significou o início de uma reformulação conceitual, que ainda está a acontecer ${ }^{22}$.

A legislação sofreu profundas alterações para abranger a tecnologia digital. Da Lei n. ${ }^{\circ} 5.988 / 73$, vigente quando do início da era digital, para a Lei n. $^{\circ} 9.610 / 98$, promulgada justamente quando se discutiam questões pertinentes à temática em pauta, apontam-se na planilha abaixo as seguintes mudanças, movidas com o fito de abarcar as novas tecnologias e no que interessa ao presente estudo:

228 ROCHA, Maria Victoria. Multimédia e direito de autor: alguns problemas. 1996. Disponível em: $<$ http://www.ciberjus.net/revista/multimedia.htm>. Acesso em: 6 set. 2007.

229 Nesse sentido, Deborah De Angelis, para quem "tutto ciò comporta un passaggio dal concetto di musica, intesa come prodotto fisico e tangibile, a quello di contenuto impalpabile ed immateriale, con tutte le conseguenze che ne derivano sul piano sociale e giuridico. La possibilità di scaricare brani musicali dalla rete, ad esempio, oltre a creare nuovi modelli di business e mercati complementari, rappresenta anche un pericolo per il diritto d'autore, nonostante la vigenza di leggi e trattati internazionali emanati per la sua protezione". (De ANGELIS, La tutela giuridica..., p.82). 


\begin{tabular}{|c|c|}
\hline LEI N. $^{\circ} 5.988 / 73$ & LEI N. $^{\circ} 9.610 / 98$ \\
\hline $\begin{array}{l}\text { Art. 4. }{ }^{\circ} \text { Para os efeitos desta lei, considera-se: } \\
\text { II - transmissão ou emissão - a difusão, por meio de } \\
\text { ondas radioelétricas, de sons, ou de sons e imagens; }\end{array}$ & $\begin{array}{l}\text { Art. 5. }{ }^{\circ} \text { Para os efeitos desta Lei, considera-se: } \\
\text { II - transmissão ou emissão - a difusão de sons ou de } \\
\text { sons e imagens, por meio de ondas radioelétricas; } \\
\text { sinais de satélite; fio, cabo ou outro condutor; meios } \\
\text { óticos ou qualquer outro processo eletromagnético; }\end{array}$ \\
\hline Não havia o conceito de distribuição. & $\begin{array}{l}\text { Art. 5. }{ }^{\circ} \text { Para os efeitos desta Lei, considera-se: } \\
\text { IV - distribuição - a colocação à disposição do } \\
\text { público do original ou cópia de obras literárias, } \\
\text { artísticas ou científicas, interpretações ou execuções } \\
\text { fixadas e fonogramas, mediante a venda, locação ou } \\
\text { qualquer outra forma de transferência de } \\
\text { propriedade ou posse; }\end{array}$ \\
\hline $\begin{array}{l}\text { Art. } 4 .^{\circ} \text { Para os efeitos desta lei, considera-se: } \\
\text { IV - reprodução - a cópia de obra literária, científica } \\
\text { ou artística bem como de fonograma; }\end{array}$ & $\begin{array}{l}\text { Art. 5. Para os efeitos desta Lei, considera-se: } \\
\text { VI - reprodução - a cópia de um ou vários } \\
\text { exemplares de uma obra literária, artística ou } \\
\text { científica ou de um fonograma, de qualquer forma } \\
\text { tangível, incluindo qualquer armazenamento } \\
\text { permanente ou temporário por meios eletrônicos ou } \\
\text { qualquer outro meio de fixação que venha a ser } \\
\text { desenvolvido; }\end{array}$ \\
\hline $\begin{array}{l}\text { Art. } \text {. }^{\circ} \text { Para os efeitos desta lei, considera-se: } \\
\text { VII - fonograma - a fixação, exclusivamente sonora, } \\
\text { em suporte material; }\end{array}$ & $\begin{array}{l}\text { Art. 5. Para os efeitos desta Lei, considera-se: } \\
\text { IX - fonograma - toda fixação de sons de uma } \\
\text { execução ou interpretação ou de outros sons, ou de } \\
\text { uma representação de sons que não seja uma fixação } \\
\text { incluída em uma obra audiovisual; }\end{array}$ \\
\hline $\begin{array}{l}\text { Art. } 4 .^{\circ} \text { Para os efeitos desta lei, considera-se: } \\
\text { X - produtor: a) fonográfico ou videofonográfico - a } \\
\text { pessoa física ou jurídica que, pela primeira vez, } \\
\text { produz o fonograma ou o videofonograma; }\end{array}$ & $\begin{array}{l}\text { Art. 5. Para os efeitos desta Lei, considera-se: } \\
\text { XI - produtor - a pessoa física ou jurídica que toma a } \\
\text { iniciativa e tem a responsabilidade econômica da } \\
\text { primeira fixação do fonograma ou da obra } \\
\text { audiovisual, qualquer que seja a natureza do } \\
\text { suporte utilizado; }\end{array}$ \\
\hline $\begin{array}{l}\text { Art. 4. }{ }^{\circ} \text { Para os efeitos desta lei, considera-se: } \\
\text { XI - empresa de radiodifusão - a empresa de rádio ou } \\
\text { de televisão, ou meio análogo, que transmite, com a } \\
\text { utilização ou não, de fio, programas ao público; }\end{array}$ & $\begin{array}{l}\text { Art. } 5 .^{\circ} \text { Para os efeitos desta Lei, considera-se: } \\
\text { XII - radiodifusão - a transmissão sem fio, inclusive } \\
\text { por satélites, de sons ou imagens e sons ou das } \\
\text { representações desses, para recepção ao público e a } \\
\text { transmissão de sinais codificados, quando os meios } \\
\text { de decodificação sejam oferecidos ao público pelo } \\
\text { organismo de radiodifusão ou com seu } \\
\text { consentimento; }\end{array}$ \\
\hline
\end{tabular}




\begin{tabular}{|c|c|}
\hline LEI N. $^{\circ} 5.988 / 73$ & LEI N. $^{\circ} 9.610 / 98$ \\
\hline 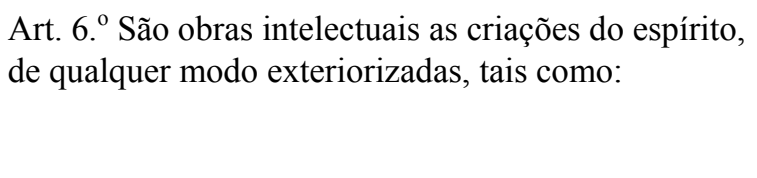 & $\begin{array}{l}\text { Art. } 7 .^{\circ} \text { São obras intelectuais protegidas as criações } \\
\text { do espírito, expressas por qualquer meio ou fixadas } \\
\text { em qualquer suporte, tangível ou intangível, } \\
\text { conhecido ou que se invente no futuro, tais como: }\end{array}$ \\
\hline Não haviam tais previsões. & $\begin{array}{l}\text { Art. 29. Depende de autorização prévia e expressa } \\
\text { do autor a utilização da obra, por quaisquer } \\
\text { modalidades, tais como: } \\
\text { VII - a distribuição para oferta de obras ou } \\
\text { produções mediante cabo, fibra ótica, satélite, ondas } \\
\text { ou qualquer outro sistema que permita ao usuário } \\
\text { realizar a seleção da obra ou produção para percebê- } \\
\text { la em um tempo e lugar previamente determinados } \\
\text { por quem formula a demanda, e nos casos em que o } \\
\text { acesso às obras ou produções se faça por qualquer } \\
\text { sistema que importe em pagamento pelo usuário; } \\
\text { VIII - a utilização, direta ou indireta, da obra } \\
\text { literária, artística ou científica, mediante: h) emprego } \\
\text { de satélites artificiais; i) emprego de sistemas óticos, } \\
\text { fios telefônicos ou não, cabos de qualquer tipo e } \\
\text { meios de comunicação similares que venham a ser } \\
\text { adotados; } \\
\text { IX - a inclusão em base de dados, o armazenamento } \\
\text { em computador, a microfilmagem e as demais } \\
\text { formas de arquivamento do gênero; } \\
\text { X - quaisquer outras modalidades de utilização } \\
\text { existentes ou que venham a ser inventadas. }\end{array}$ \\
\hline Não havia tal previsão. & $\begin{array}{l}\text { Art. 30. No exercício do direito de reprodução, o } \\
\text { titular dos direitos autorais poderá colocar à } \\
\text { disposição do público a obra, na forma, local e pelo } \\
\text { tempo que desejar, a título oneroso ou gratuito. } \\
\S 1 .^{\circ} \text { O direito de exclusividade de reprodução não } \\
\text { será aplicável quando ela for temporária e apenas } \\
\text { tiver o propósito de tornar a obra, fonograma ou } \\
\text { interpretação perceptível em meio eletrônico ou } \\
\text { quando for de natureza transitória e incidental, desde } \\
\text { que ocorra no curso do uso devidamente autorizado } \\
\text { da obra, pelo titular. } \\
\S 2 .^{\circ} \text { Em qualquer modalidade de reprodução, a } \\
\text { quantidade de exemplares será informada e } \\
\text { controlada, cabendo a quem reproduzir a obra a } \\
\text { responsabilidade de manter os registros que } \\
\text { permitam, ao autor, a fiscalização do aproveitamento } \\
\text { econômico da exploração. }\end{array}$ \\
\hline
\end{tabular}




\begin{tabular}{|c|c|}
\hline LEI N. $^{\circ} 5.988 / 73$ & LEI N. $^{\circ} 9.610 / 98$ \\
\hline $\begin{array}{l}\text { Art. } 49 \text {. Não constitui ofensa aos direitos do autor: } \\
\text { II - A reprodução, em um só exemplar, de qualquer } \\
\text { obra, contando que não se destine à utilização com } \\
\text { intuito de lucro; }\end{array}$ & Não há tal previsão. \\
\hline Não haviam tais previsões. & $\begin{array}{l}\text { Art. } 87 . \text { O titular do direito patrimonial sobre uma } \\
\text { base de dados terá o direito exclusivo, a respeito da } \\
\text { forma de expressão da estrutura da referida base, de } \\
\text { autorizar ou proibir: } \\
\text { I - sua reprodução total ou parcial, por qualquer } \\
\text { meio ou processo; } \\
\text { II - sua tradução, adaptação, reordenação ou } \\
\text { qualquer outra modificação; } \\
\text { III - a distribuição do original ou cópias da base de } \\
\text { dados ou a sua comunicação ao público; } \\
\text { IV - a reprodução, distribuição ou comunicação ao } \\
\text { público dos resultados das operações mencionadas } \\
\text { no inciso II deste artigo. }\end{array}$ \\
\hline $\begin{array}{l}\text { Art. 98. Tem o produtor de fonogramas o direito de } \\
\text { autorizar ou proibir-lhes a reprodução, direta ou } \\
\text { indireta, a transmissão e a retransmissão por } \\
\text { empresa de radiodifusão, bem como a execução } \\
\text { pública a realizar-se por qualquer meio. }\end{array}$ & $\begin{array}{l}\text { Art. 93. O produtor de fonogramas tem o direito } \\
\text { exclusivo de, a título oneroso ou gratuito, autorizar- } \\
\text { lhes ou proibir-lhes: } \\
\text { I - a reprodução direta ou indireta, total ou parcial; } \\
\text { II - a distribuição por meio da venda ou locação de } \\
\text { exemplares da reprodução; } \\
\text { III - a comunicação ao público por meio da } \\
\text { execução pública, inclusive pela radiodifusão; } \\
\text { IV - (VETADO) } \\
\text { V - quaisquer outras modalidades de utilização, } \\
\text { existentes ou que venham a ser inventadas. }\end{array}$ \\
\hline $\begin{array}{l}\text { Art. 124. Quem vender, ou expuser à venda, obra } \\
\text { reproduzida com fraude, será solidariamente } \\
\text { responsável com o contrafator, nos termos dos } \\
\text { artigos precedentes; e, se a reprodução tiver sido } \\
\text { feita no estrangeiro, responderão, como } \\
\text { contrafatores o importador e o distribuidor. }\end{array}$ & $\begin{array}{l}\text { Art. 104. Quem vender, expuser a venda, ocultar, } \\
\text { adquirir, distribuir, tiver em depósito ou utilizar } \\
\text { obra ou fonograma reproduzidos com fraude, com a } \\
\text { finalidade de vender, obter ganho, vantagem, } \\
\text { proveito, lucro direto ou indireto, para si ou para } \\
\text { outrem, será solidariamente responsável com o } \\
\text { contrafator, nos termos dos artigos precedentes, } \\
\text { respondendo como contrafatores o importador e o } \\
\text { distribuidor em caso de reprodução no exterior. }\end{array}$ \\
\hline
\end{tabular}




\begin{tabular}{|c|c|}
\hline LEI N. $^{\circ} 5.988 / 73$ & LEI N. ${ }^{\circ} 9.610 / 98$ \\
\hline Não havia tal previsão. & $\begin{array}{l}\text { Art. 107. Independentemente da perda dos } \\
\text { equipamentos utilizados, responderá por perdas e } \\
\text { danos, nunca inferiores ao valor que resultaria da } \\
\text { aplicação do disposto no art. } 103 \text { e seu parágrafo } \\
\text { único, quem: } \\
\text { I - alterar, suprimir, modificar ou inutilizar, de } \\
\text { qualquer maneira, dispositivos técnicos introduzidos } \\
\text { nos exemplares das obras e produções protegidas } \\
\text { para evitar ou restringir sua cópia; } \\
\text { II - alterar, suprimir ou inutilizar, de qualquer } \\
\text { maneira, os sinais codificados destinados a restringir } \\
\text { a comunicação ao público de obras, produções ou } \\
\text { emissões protegidas ou a evitar a sua cópia; } \\
\text { III - suprimir ou alterar, sem autorização, qualquer } \\
\text { informação sobre a gestão de direitos; } \\
\text { IV - distribuir, importar para distribuição, emitir, } \\
\text { comunicar ou puser à disposição do público, sem } \\
\text { autorização, obras, interpretações ou execuções, } \\
\text { exemplares de interpretações fixadas em fonogramas } \\
\text { e emissões, sabendo que a informação sobre a gestão } \\
\text { de direitos, sinais codificados e dispositivos técnicos } \\
\text { foram suprimidos ou alterados sem autorização. }\end{array}$ \\
\hline
\end{tabular}

Da análise do quadro acima extraem-se duas conclusões principais: i) a Lei passou a indiscutivelmente abranger as novas tecnologias, tanto por meio de enumerações diretas quanto indiretas; ii) a lei endureceu - e muito - na proteção aos direitos autorais e nas respectivas sanções ao seu descumprimento, comprometendo o que José de Oliveira Ascensão denomina "imunidade do uso privado"230.

Analisar-se-ão oportunamente, inseridas no contexto deste estudo, as principais alterações no regramento, trazidas pelas novas tecnologias, permeadas pela defesa do status quo, sob o prisma de sua adequação normativa em face das práticas sociais contemporâneas e do bem-estar comum ${ }^{231}$.

230 Para ele, "o direito de autor recai sobre formas de utilização pública da obra. Deixa de fora, por natureza, o uso privado. Não há aqui um limite; há a própria fronteira, em relação a actividades diversas das que são objecto de exclusivo" (ASCENSÃO, Novas tecnologias..., p.123).

231 "Des pratiques sociales qui se multiplient (l'avortement lorsqu'il n'est pas autorisé dans uns pays) ont à maintes reprises conduit le législateur et l'ensemble de la société a s'interroger sur le bien-fondé de la loi et sur les vertus de réactions défensices". (BENHAMOU e FARCHY, Droit d'auteur..., p.60). 


\subsection{A DISTRIBUIÇÃO DE OBRAS MUSICAIS}

A lei autoral vigente inovou ao incluir a definição de distribuição, no art. 5, IV, cujo núcleo consiste no ato de disponibilizar ao público o "original ou cópia de obras literárias, artísticas ou científicas, interpretações ou execuções fixadas e fonogramas, mediante a venda, locação ou qualquer outra forma de transferência de propriedade ou posse"232, constante dos Tratados da OMPI (Organização Mundial da Propriedade Intelectual) sobre Direito de Autor (WCT), e sobre interpretações ou execuções e fonogramas (WPPT), ambos de 1996 e dos quais o Brasil não é parte:

Tratado da OMPI sobre Direito de Autor (WCT)

Artigo 6. ${ }^{\circ}$

(1) Os autores de obras literárias e artísticas do direito exclusivo de autorizar a colocação à disposição do público do original e de cópias das suas obras por meio da venda ou por outra forma de transferência de propriedade.

Tratado da OMPI sobre interpretações ou execuções e fonogramas (WPPT) Artigo 8. ${ }^{\circ}$

(1). Os artistas intérpretes ou executantes gozam do direito exclusivo de autorizar a colocação à disposição do público do original e de cópias das suas prestações fixadas em fonogramas, por meio da venda ou por outra forma de transferência de propriedade.

\section{Artigo 12. ${ }^{\circ}$}

(1) Os produtores de fonogramas gozam do direito exclusivo de autorizar a colocação à disposição do público do original e de cópias dos seus fonogramas, por meio da venda ou por outra forma de transferência de propriedade.

Os tratados OMPI de 1996, também conhecidos como "tratados da internet", foram elaborados a partir da iniciativa dos Estados Unidos da América, o qual já dispunha de estudos que visavam a uma legislação interna. Entretanto, em vista do caráter transnacional da internet, foi considerado que melhor seria a inclusão no direito internacional, para

232 E também o direito de locação, oriundo dos mesmos tratados, mas nesse caso também previsto no acordo TRIPS, artigo 11, do qual o Brasil é parte signatária. Diz o art. 5. ${ }^{\circ}$ da LDA: "Para os efeitos desta Lei, considera-se: IV - distribuição - a colocação à disposição do público do original ou cópia de obras literárias, artísticas ou científicas, interpretações ou execuções fixadas e fonogramas, mediante a venda, locação ou qualquer outra forma de transferência de propriedade ou posse". Também, o artigo 93 do mesmo diploma: "Art. 93. O produtor de fonogramas tem o direito exclusivo de, a título oneroso ou gratuito, autorizar-lhes ou proibir-lhes: II - a distribuição por meio da venda ou locação de exemplares da reprodução". Note-se, outrossim, que o conceito de distribuição constante da lei específica não equivale ao do Código Civil de 2002, do contrato de agência e distribuição, constante dos artigos 710 e seguintes. 
depois internalizar as regras, o que foi feito por meio do DMCA - The Digital Millenium Copyright Act, de $1998^{233}$.

É de notar que os países da Comunidade Européia não compuseram as assembléias que definiram tais tratados da OMPI e que, muito embora deles sejam partes, ainda não os internalizaram em seus ordenamentos jurídicos, mesmo que a Diretiva 2001/29/CE já tenha previsto a execução de alguns dos dispositivos que constam de tais instrumentos internacionais ${ }^{234}$.

Com efeito, a introdução da distribuição alargou a proteção autoral, passando a inequivocamente abranger os novos meios informáticos, em conjunto com a reprodução. Percebe-se, assim, sensível alteração nos direitos exclusivos patrimoniais do direito de autor, do início do século passado ${ }^{235}$ (e também início da indústria fonográfica) para a atualidade. De todo modo, importante ressaltar que a distribuição não se restringe somente a tais meios e aplica-se também ao meio físico.

Com propriedade, José de Oliveira Ascensão esclarece que

o entendimento de distribuição não é o mesmo em todos os países. Nos Estados Unidos da América considera-se que toda a transmissão digital implica uma distribuição. E isto porque se qualificam como tal as reproduções meramente tecnológicas que se produzem no seio dos computadores de acolhimento. ${ }^{236}$

233 Há quem diga, entretanto, que o então Presidente Bill Clinton sofreu forte oposição à sua tentativa de regular os direitos autorais na internet, sob nítida influência dos titulares de direitos autorais e, então, sugestionado por seus auxiliares, preferiu, por meio da chamada "mão-de-gato", fazer com que a OMPI adotasse os termos pretendidos pelo Governo americano e, então, justificar a adoção das normas no âmbito interno pelo acolhimento de tratado firmado.

234 Preâmbulo da Diretiva da Comunidade Européia 2001/29/CE "(15) A Conferência Diplomática realizada sob os auspícios da Organização Mundial da Propriedade Intelectual (OMPI), em Dezembro de 1996, conduziu à aprovação de dois novos tratados, o Tratado da OMPI sobre o Direito de Autor e o Tratado da OMPI sobre Prestações e Fonogramas, que tratam, respectivamente, da protecção dos autores e da protecção dos artistas intérpretes ou executantes e dos produtores de fonogramas. Estes tratados actualizam significativamente a protecção internacional do direito de autor e dos direitos conexos, incluindo no que diz respeito à denominada "agenda digital", e melhoram os meios de combate contra a pirataria a nível mundial. A Comunidade e a maioria dos seus Estados-Membros assinaram já os tratados e estão em curso os procedimentos para a sua ratificação pela Comunidade e pelos seus Estados-Membros. A presente directiva destina-se também a dar execução a algumas destas novas obrigações internacionais".

235 Os elementos patrimoniais do direito de autor se resumiam em dois, de acordo com Clóvis Bevilacqua: "direito autoral é o que tem o autor de obra literária, científica ou artística, de ligar o seu nome às produções do seu espírito e de reproduzí-las, ou transmiti-las. Na primeira relação, é manifestação da personalidade do autor; na segunda, é de natureza real, econômica". (BEVILACQUA, Direito das coisas, p.267). Atualmente são diversos os direitos patrimoniais dispostos na LDA, art. 29, inclusive o de distribuição.

236 ASCENSÃO, Aspectos jurídicos..., p.85. O autor afirma que "a distribuição supõe a disposição de exemplares físicos que são o suporte da obra", com o que dá a crer que não seria possível a distribuição on-line, mas complementa, concordando com tal possibilidade "é porém possível uma verdadeira distribuição 
De acordo com lei autoral brasileira, para que ocorra a distribuição é necessário que o ato de disponibilizar ao público esteja vinculado aos negócios jurídicos de compra e venda, locação ou qualquer outra forma de transferência de propriedade ou posse ${ }^{237}$.

Ocorre que a mesma LDA, no art. 107, IV 238 , menciona como ilícita a distribuição desautorizada, sancionando quem puser à disposição do público sem autorização "obras, interpretações ou execuções, exemplares de interpretações fixadas em fonogramas e emissões, sabendo que a informação sobre a gestão de direitos, sinais codificados e dispositivos técnicos foram suprimidos ou alterados sem autorização".

Em que pese o fato de o art. 107 representar verdadeiro intruso na lei autoral, já que pode sancionar condutas não necessariamente vinculadas à infração aos direitos autorais conforme será visto no presente estudo -, tal artigo faz distinção entre a distribuição e o simples ato de disponibilizar ao público, talvez para abranger de forma inequívoca os usuários que porventura disponibilizem na internet bens protegidos pelos direitos autorais, os quais, entretanto, não seriam considerados distribuidores no sentido de quem opera a distribuição.

Entretanto, tal distinção não se demonstra necessária, uma vez que o conceito legal de distribuição é amplo e, ao prever "qualquer outra forma de transferência de propriedade ou posse", o que acaba por também atingir o usuário que porventura venha a oferecer, mesmo que sem cobrança, uma música por meio de um sítio na internet ou sistema de troca de arquivos (P2P), já que a transferência de propriedade pode, por exemplo, ocorrer por meio de doação.

em linha". Refere-se aos arquivos digitais como os que contém, por exemplo, um livro digital. Em sentido contrário, Deborah de Angelis, ao tratar da distribuição, para quem "le espressioni 'originali' e 'copie', oggetto del diritto di distribuzione, si riferiscono esclusivamente agli esemplari fissi messi in circolazione in supporto tangibile. Il diritto in questione, avente ad oggetto esclusivamente i supporti tangibili delle opere, è l'unico a non essere collegato con le utilizzazione proprie di internet". (De ANGELIS, La tutela giuridica..., p.97-98).

${ }^{237}$ LDA, art. 5, IV.

238 LDA, art. 107, "IV - distribuir, importar para distribuição, emitir, comunicar ou puser à disposição do público, sem autorização, obras, interpretações ou execuções, exemplares de interpretações fixadas em fonogramas e emissões, sabendo que a informação sobre a gestão de direitos, sinais codificados e dispositivos técnicos foram suprimidos ou alterados sem autorização". 
Esclareça-se, por oportuno, que a aventada transferência de propriedade ou de posse ocorre em relação ao exemplar ${ }^{239}$, ou seja, meio que comporta a obra, no caso da música a sua fixação e (ou) o fonograma, que bem pode ser, no caso brasileiro, o arquivo digital.

Nesse sentido, a própria LDA considera como meio de fixação tangível o armazenamento permanente ou temporário por meios eletrônicos ao definir reprodução como sendo "a cópia de um ou vários exemplares de uma obra literária, artística ou científica ou de um fonograma, de qualquer forma tangível, incluindo qualquer armazenamento permanente ou temporário por meios eletrônicos ou qualquer outro meio de fixação que venha a ser desenvolvido"240.

Assim, interpreta-se a partir da lei autoral brasileira que, no caso da música digital, para a ocorrência da distribuição se faz necessária a reprodução. Existem situações configuradoras da existência de um ou de outro instituto, ou mesmo os dois simultaneamente ${ }^{241}$.

$239 \mathrm{O}$ art. 5, V da LDA corrobora tal entendimento, por exclusão, na medida em que designa a comunicação ao público como o "ato mediante o qual a obra é colocada ao alcance do público, por qualquer meio ou procedimento e que não consista na distribuição de exemplares" [grifo nosso].

240 LDA, art. 5. ${ }^{\circ}, \mathrm{VI}$.

241 São as chamadas "formas híbridas" de utilização, conforme Fiscor, citado por Alexandre Dias Pereira. Há a cumulação com reprodução em vista do armazenamento temporário no computador do usuário, que ocorre em tal forma de utilização. Entretanto, ora se concorda com a opinião de Alexandre Dias Pereira, para quem "a prática de actos autorizados pelo autor ou pela lei deveria excluir do âmbito desse direito a reprodução temporária tecnicamente necessária para o efeito". (PEREIRA, Informática, direito..., p.57). Tal entendimento foi levado em conta pela Diretiva da Comunidade Européia 2001/29/CE, publicada após a escrita da obra do autor: "1. Os actos de reprodução temporária referidos no artigo 2.o, que sejam transitórios ou episódicos, que constituam parte integrante e essencial de um processo tecnológico e cujo único objectivo seja permitir: a) Uma transmissão numa rede entre terceiros por parte de um intermediário, ou b) Uma utilização legítima de uma obra ou de outro material a realizar, e que não tenham, em si, significado económico, estão excluídos do direito de reprodução previsto no artigo 2. ", sob a justificativa, no preâmbulo, de que "(33) O direito exclusivo de reprodução deve ser sujeito a uma excepção para permitir certos actos de reprodução temporária, que são reproduções transitórias ou pontuais, constituindo parte integrante e essencial de um processo tecnológico efectuado com o único objectivo de possibilitar, quer uma transmissão eficaz numa rede entre terceiros por parte de um intermediário, quer a utilização legítima de uma obra ou de outros materiais protegidos. Os actos de reprodução em questão não deverão ter, em si, qualquer valor económico. Desde que satisfeitas essas condições, tal excepção abrange igualmente os actos que possibilitam a navegação ('browsing') e os actos de armazenagem temporária ('caching'), incluindo os que permitem o funcionamento eficaz dos sistemas de transmissão, desde que o intermediário não altere o conteúdo da transmissão e não interfira com o legítimo emprego da tecnologia, tal como generalizadamente reconhecido e praticado pela indústria, para obter dados sobre a utilização da informação. Uma utilização deve ser considerada legítima se tiver sido autorizada pelo titular de direitos e não estiver limitada por lei". 
Por exemplo, o usuário que comprou um $\mathrm{CD}$ e transfere seu conteúdo para o computador ou para outro CD pratica uma reprodução ${ }^{242}$.

Se o mesmo usuário, após a introdução em seu computador, deixa o arquivo digital correspondente disponível numa pasta compartilhada de seu sistema e torna possível a seus amigos que o reproduzam e armazenem em seus computadores, trata-se de uma distribuição. Isso porque se entende o arquivo digital como um meio de fixação tangível, portanto exemplar, o que afastaria a comunicação ao público.

Não há, pois, que se confundir distribuição com reprodução. Enquanto a primeira torna disponível ao público original ou cópia de obras literárias, artísticas ou científicas, interpretações ou execuções fixadas e fonogramas, a segunda significa o ato de praticar a cópia de tais obras, interpretações ou execuções fixadas e fonogramas.

De todo modo, é comum que surjam dúvidas sobre qual o conceito aplicável em cada caso. É para o que alerta Alexandre Dias Pereira ${ }^{243}$.

Todavia, apesar de não se tratar de uma tipificação taxativa das formas de utilização, torna-se necessário saber em que termos se processa a utilização de obras por computador. Assim será necessário pressupor uma noção do que é usar uma obra e, em função dessa noção, determinar, por exemplo, se certos actos como o carregamento e o armazenamento de uma obra na memória de um computador afectam o direito de gozo exclusivo e em que termos. $\mathrm{O}$ mesmo vale, mutatis mutandis, para actos de transmissão de obras entre sistemas informáticos em rede. Trata-se de reprodução ou de comunicação ao público? Não serão antes actos de distribuição?

A tais dúvidas a lei brasileira auxilia a dirimir, já que em seu art. 5. ${ }^{\circ}$ elucida o significado de diversas expressões que constam da LDA, com o que é facilitada a sua interpretação. Aliás, oportuno ressaltar que a ampla definição de transmissão ${ }^{244}$ abarca tanto a distribuição quanto a reprodução ou a comunicação ao público, quando promovidas pela internet. Noutras palavras, o ato de transmitir é requisito essencial para que haja as demais utilizações.

242 No caso de tal reprodução não ser autorizada (e geralmente não é), acaba por praticar a contrafação, prevista no art. 5. ${ }^{\circ}$ VII da LDA.

243 PEREIRA, Música e eletrônica..., p.315.

244 LDA, "art. 5. ${ }^{\circ}$, II - transmissão ou emissão - a difusão de sons ou de sons e imagens, por meio de ondas radioelétricas; sinais de satélite; fio, cabo ou outro condutor; meios óticos ou qualquer outro processo eletromagnético". É perceptível pela análise do quadro comparativo acima, mediante a leitura coordenada entre os art. 4, II e XI da lei 5.988/73 com o art. 5, II e XII, que antes o ato de transmitir possuía clara vinculação com a atividade de radiodifusão, enquanto que agora se constata a nítida e bem definida diferenciação. 
Diante disso, sob a égide da LDA a resposta ao questionamento do autor português está vinculada à forma do ato em questão, pelo que se demanda uma análise de cada caso concreto: i) se for uma transferência de arquivo contendo fonograma mediante cobrança, por determinado sítio da internet que o disponibiliza ao público, trata-se de distribuição, a qual, nessa forma on-line, acompanhada está da reprodução, que é o ato de copiar o arquivo digital para o computador do recipiente; ii) se for o envio, por e-mail, de um arquivo contendo fonograma de um usuário a outro, em ato privado, trata-se de reprodução. Se não-autorizada: contrafação; iii) se for audiência de música por meio de uma "rádio online", será comunicação ao público cumulada com reprodução ${ }^{245}$; iv) se for a troca de arquivos por meio de redes $\mathrm{P} 2 \mathrm{P}$, será distribuição e reprodução.

Note-se que o conceito de distribuição adotado na lei autoral brasileira é oriundo da interpretação formulada pelos membros da assembléia da OMPI, que versou sobre a instituição dos tratados de internet nas chamadas "Declarações Acordadas" acerca dos arts. 6 e 7 do Tratado sobre Direito de Autor (WCT) e arts. 2 (e), 8, 9, 12 e 13 do Tratado sobre prestações e fonogramas (WPPT): "as expressões 'cópias' e 'original e cópias' utilizadas nestes artigos para designar o objecto do direito de distribuição e do direito de aluguer neles previstos referem-se exclusivamente a cópias fixadas que possam ser postas em circulação enquanto objectos materiais" [grifo nosso].

O texto normativo da Comunidade Européia, a qual realizou criteriosos estudos para a edição da Diretiva 2001/29/CE 246 , prevê o direito de distribuição no art. 4. : : "1. Os Estados-Membros devem prever a favor dos autores, em relação ao original das suas obras ou respectivas cópias, o direito exclusivo de autorizar ou proibir qualquer forma de distribuição ao público através de venda ou de qualquer outro meio".

245 Nesse caso, a comunicação ao público se dá cumulativamente com a reprodução mas, se aquela foi devidamente autorizada pelo titular, o mesmo não pode reclamar eventual infração ao direito de reprodução pelo caráter transitório e incidental que caracteriza o armazenamento temporário para a audição via rádio "on-line". Trata-se de uma limitação aos direitos autorais disposta na LDA: "Art. 30. No exercício do direito de reprodução, o titular dos direitos autorais poderá colocar à disposição do público a obra, na forma, local e pelo tempo que desejar, a título oneroso ou gratuito.

$\S 1 .^{\circ} \mathrm{O}$ direito de exclusividade de reprodução não será aplicável quando ela for temporária e apenas tiver o propósito de tornar a obra, fonograma ou interpretação perceptível em meio eletrônico ou quando for de natureza transitória e incidental, desde que ocorra no curso do uso devidamente autorizado da obra, pelo titular".

246 Diretiva da Comunidade Européia 2001/29/CE: "(28) A protecção do direito de autor nos termos da presente directiva inclui o direito exclusivo de controlar a distribuição de uma obra incorporada num produto tangível". 
A LDA e o regramento autoral europeu têm em comum o fato de que ambas consideram possível a distribuição on-line, ao contrário do consta dos tratados OMPI, mormente as "Declarações Acordadas". A primeira foi promulgada em 1998, justo quando "a orientação comum estadunidense e, numa primeira fase, européia, apontava no sentido do alargamento do direito de distribuição, abrangendo a distribuição imaterial", sendo que posteriormente a representação comunitária européia propôs, em nível internacional, que "a via aparentemente adoptada em sede de transmissão em linha de base de dados favorecia a inclusão no direito de comunicação ao público (juntamente, por ex., com a radiodifusão) dos actos de tornar as obras acessíveis ao público por meios com ou sem fios de tal modo que os membros do público pudessem aceder a tais obras no local e no tempo por si individualmente escolhidos"247 (definição de comunicação ao público adotada na Diretiva 2001/29/CE).

A construção legal brasileira, no sentido de que o armazenamento em meio digital é considerado meio físico tangível, constante da definição de reprodução, acaba por levar à efetiva conclusão de que, na internet, quando há a transferência de arquivos de um computador para outro, a partir de mecanismo que disponibilize exemplar de música digital ao público, trata-se de distribuição on-line ${ }^{248}$, que necessariamente há de utilizar a reprodução como meio.

Nos artigos em que a lei autoral brasileira menciona o vocábulo público deve-se interpretar seu significado como sendo aquele conjunto de pessoas indetermináveis que podem ter acesso à obra ou direito conexo tutelado pelos direitos autorais. Noutras palavras, sob o enfoque em questão, isso justifica o fato de um fonograma em arquivo digital enviado de um amigo para outro por correio eletrônico não ser considerado ato de distribuição, mas sim de reprodução. Caso isso ocorra na esfera privada do usuário não se configura também a comunicação ao público.

Aliás, a própria denominação do ouvinte de música digital como "usuário" demonstra com exatidão a modificação que se operou na definição de público consumidor, já que aquele

247 PEREIRA, Informática, direito..., p.58-59.

248 Ressalte-se que, no caso de distribuição on-line, não há que se falar em esgotamento ou exaustão do direito de distribuição em relação à revenda do meio físico do objeto de proteção, o que ocorre no caso da distribuição física. 
termo revela o poder que passou a exercer em vista das mudanças tecnológicas, decidindo o que quer escutar e quando.

Informa Alexandre Dias Pereira que na Alemanha foi proposta a alteração da noção de público e que "a comunicação é pública se for destinada a uma ou mais pessoas que pertencem ao público. Não há público quando entre a ou as pessoas e o organizador existem relações pessoais"249.

Outrossim, o conceito de público é caríssimo ao direito de autor, de modo que deveria constar sua definição junto às outras dos prolegômenos da lei autoral, para um delineamento preciso dos limites dos direitos autorais.

Finalmente, importante questão trazida pela distribuição digital de obras musicais pode ser argüida, no que se refere ao esgotamento ou exaustão de direitos de distribuição, aplicável em relação ao meio físico de fixação.

O esgotamento dos direitos de distribuição ocorre no momento em que um CD é vendido pela primeira vez ao usuário, que pode, a partir disso, revendê-lo a terceiros, já que é proprietário do meio físico que contém a obra musical. Desse modo, o titular dos direitos autorais vê esgotar seus direitos de distribuição em relação àquela cópia, e a revenda que é praticada pelo usuário se dá sem qualquer satisfação àquele 250 .

Para Alexandre Dias Pereira:

\begin{abstract}
na verdade, este princípio foi elaborado pela jurisprudência para os casos em que a obra é comercializada mediante suportes materiais, já não para a prestação de serviços. Ora, se se considerar a transmissão digital em linha como um acto de prestação de serviços, então parece excluir-se o princípio do esgotamento do direito de distribuição, reforçando os poderes de controlo do titular de direitos, pois poderá impedir a distribuição posterior da cópia obtida. ${ }^{251}$
\end{abstract}

249 "Mas, o problema da utilização ser feita em privado levou mesmo a que, na Alemanha, tivesse sido proposta a alteração da noção de público. Com efeito, nos termos do $\S 15$ (3) UrhG, a comunicação (Wiedergabe) da obra seria pública se fosse destinada a um número de pessoas, a menos que essas pessoas formassem um grupo definido e estivessem interrelacionadas pessoalmente por relações mútuas ou por uma relação com o organizador. Isto significava, nas palavras de Ulmer, que 'a comunicação é privada apenas quando os participantes individuais forem determinados e estejam ligados pessoalmente entre si. Exemplos maiores são as comunidades entre professores e alunos, entre amigos e parentes familiares'. Ora, porque na transmissão em linha interactiva existiria uma relação com o organizador da comunicação tornou-se necessário esclarecer que essa relação não deveria ser de natureza pessoal para que pudesse haver comunicação ao público". (PEREIRA, Informática, direito..., p.416).

250 É o caso, por exemplo, de um livro que é adquirido e depois da leitura revendido pelo leitor a um "sebo" ou a outro leitor. $\mathrm{O}$ direito de autor permanece com seu titular, entretanto o direito de distribuição se esgota na primeira venda.

251 PEREIRA, Informática, direito..., p.436. 
Com efeito, em se tratando de prestação de serviços envolvendo um bem com relativa ausência de suporte materializado, como é o caso na internet, o titular não vê esgotado seu direito de distribuição, pelo que, também nesse aspecto, os direitos autorais enrijeceram.

\subsection{A EDIÇÃO MUSICAL}

Noutras épocas, já dizia Pontes de Miranda $^{252}$ que "O contrato de gravação de discos é contrato de edição. (...) gravar disco é editar", constatação que denota a fusão, naquela época, das figuras do produtor musical e do editor ${ }^{253}$.

Para Fabio Maria De Mattia: "com relação ao contrato de edição nós temos que indicar desde logo dois elementos que necessariamente aparecem na sua conceituação: a reprodução da obra intelectual e a sua difusão".

A adoção do contrato de edição sempre teve lugar no segmento da indústria fonográfica, conforme já visto no capítulo primeiro deste trabalho. Por analogia à edição literária, foco do conteúdo das antigas normas autorais, o produtor fonográfico também assumia as vezes de editor, especialmente no sentido da exploração do conteúdo econômico da obra, com o que buscava assegurar direitos antes mesmo da construção legislativa internacional que introduziu os direitos conexos, dentre os quais aqueles dos produtores de fonogramas (o que, também conforme já visto no capítulo primeiro, ocorreu com a Convenção de Roma, de 1961).

Com efeito, em geral as representantes da indústria fonográfica desempenhavam o papel de produtor, editor e de cessionário titular de direito de autor.

252 PONTES DE MIRANDA, Tratado de direito privado, Tomo XVI, p.160.

253 Para Fabio Maria De Mattia: "Com relação ao contrato de edição nós temos que indicar desde logo dois elementos que necessariamente aparecem na sua conceituação: a reprodução da obra intelectual e a sua difusão. Apenas a impressão da obra intelectual sem a difusão, sem, portanto, a colocação da obra em contacto com o público, só a publicação não adimple a obrigação assumida pelo editor. O contrato de edição, pois, tem um duplo escopo: como resultado imediato visa-se a edição e como resultado mediato a difusão da edição ou do conteúdo do livro objeto do contrato pelo que acolhe a definição do autor Pierre Alain Tâche: 'Le contrat d'édition est un contrat par lequel l'auteur d'une oeuvre protegée ou les ayants cause s'engagent à la ceder à um éditeur, qui s'oblige à la reproduire em um nombre plus ou moins considérable d'exemplaires et à la répandre dans le public, à son propre compte." (DE MATTIA, O autor e o editor..., p.2 e 4). Para Carlos Alberto Bittar "Em sentido estrito, contrato de edição é aquele por via do qual o autor entrega a obra ao editor, para que a reproduza mecanicamente e a explore". (BITTAR, Curso de direito autoral, p.104). Para Pontes de Miranda "o que se transfere, com o contrato de edição, não é o direito autoral de exploração, mas elemento do exercício dêsse, pela dívida e pela obrigação que assume o titular do direito autoral de exploração" (PONTES DE MIRANDA, Tratado de direito privado, Tomo XLIV, p.322). 
$\mathrm{Na}$ lei autoral de 1973, o legislador fez constar as definições de editor ${ }^{254}$ : "a pessoa física ou jurídica que adquire o direito exclusivo de reprodução gráfica da obra" e de produtor fonográfico ${ }^{255}$ : "a pessoa física ou jurídica que, pela primeira vez, produz o fonograma". Note-se que o editor adquiria o direito exclusivo de reprodução gráfica da obra, o que, em tese, excluiria a obra musical. Mesmo assim, o contrato de edição era o tipo contratual utilizado por compositores e gravadoras (produtoras fonográficas) quando não havia a transferência da titularidade dos direitos patrimoniais sobre a obra, assim como no caso de obra sob encomenda 256 .

O art. 57 da lei autoral de $1973^{257}$ é o que tornava típico o contrato de edição, estipulando ao editor a obrigatoriedade da reprodução mecânica e da divulgação da obra autoral, ao qual então é conferida a aquisição do direito exclusivo de publicá-la e explorá-la.

$\mathrm{Na}$ lei atual, de 1998, a definição de editor foi alterada para "a pessoa física ou jurídica à qual se atribui o direito exclusivo de reprodução da obra e o dever de divulgá-la, nos limites previstos no contrato de edição $258 "$ ", do mesmo modo que o art. 53, que trata do contrato de edição, dispõe sobre autorização conferida ao editor ${ }^{259}$. Mediante contrato de edição, o editor, obrigando-se a reproduzir e a divulgar a obra literária, artística ou científica, fica

254 Lei 5.988/73, art. 4, IX.

255 Lei 5.988/73, art. 4, X, a.

256 Pontes de Miranda menciona a possibilidade de se haver contrato misto: "Se o editor se faz adquirente, encomendando a obra, para que passe a ser sua, quando pronta, tal contrato é inconfundível com o de encomenda de obra para edição, que é o contrato de edição previsto no ad. 1.847 do Código Civil. Ali, a aquisição só se opera à entrega da obra (arts. 1.287-1.247); aqui, o que o editor adquire é o direito de editar. Pode-se pensar em contrato misto de empreitada e de mandato se alguém se obriga a imprimir e difundir a obra, sem adquirir direito de edição. Ou em contrato misto de empreitada e de mandato na edição ou de comissão, se o empreiteiro (editor) assume a obrigação de reproduzir a obra à custa do autor, recebendo comissão sobre os exemplares vendidos. Se a obra já estava impressa, trata-se de simples contrato de comissão, ou de mandato. Pode ocorrer também que seja contrato estimatório o contrato entre o autor e o editor. Sempre que se fala de 'editor' sem que o contrato entre o autor e êle seja contrato de edição, emprega-se a expressão como indicativa de profissionalidade, e não de figurante em contrato de edição." (PONTES DE MIRANDA, Tratado de direito privado, Tomo XLIV, p.330).

257 Lei n. ${ }^{\circ}$ 5.988/73: "Art. 57 - Mediante contrato de edição, o editor, obrigando-se a reproduzir mecanicamente e a divulgar a obra literária, artística, ou científica, que o autor lhe confia, adquire o direito exclusivo a publicá-la, e explorá-la".

258 Lei n. $^{\circ} 9.610 / 98$, art. $5, \mathrm{X}$.

259 Lei n. ${ }^{\circ}$ 9.610/98: "Art. 53.Mediante contrato de edição, o editor, obrigando-se a reproduzir e a divulgar a obra literária, artística ou científica, fica autorizado, em caráter de exclusividade, a publicá-la e a explorá-la pelo prazo e nas condições pactuadas com o autor." 
autorizado, em caráter de exclusividade, a publicá-la e a explorá-la pelo prazo e nas condições pactuadas com o autor.

Já em relação à figura do produtor, a lei atual houve por modernizar a definição, incluindo a expressão "qualquer que seja a natureza do suporte utilizado"260, artifício empregado noutros artigos da lei.

Consta das atribuições do editor musical, por exemplo, fazer o registro perante os cadastros de músicas (International Standard Recording Code) e as entidades de gestão coletiva de direitos autorais, nas quais representará o autor, repartindo os proventos de acordo com o estipulado contratualmente. Ocorre, entretanto, que no segmento musical - e isso não é de hoje - o contrato de edição, ao contrário do que é estipulado na lei, trata de ceder todos os direitos patrimoniais da obra, sem contrapartida que o justifique. É o que ocorre não somente no Brasil, conforme alertam Victorio de Sanctis e Mario Fabiani261:

\begin{abstract}
O contrato de edição de obras musicais, espécie utilizada comumente para as obras de música popular e músicas de trilhas sonoras de obras audiovisuais, é o contrato que pretende ceder à propriedade do editor todos os direitos de utilização da obra, sem limite temporal ou espacial, e prevê à responsabilidade desse último também uma obrigação formal de publicação do meio físico, limitada normalmente a um número de cópias que de tão pequeno demonstra o seu significado não comercial.
\end{abstract}

Hodiernamente, as chamadas "editoras musicais" ou music publishing companies têm a atribuição de explorar o conteúdo econômico dos direitos autorais de um fonograma, "recebendo direitos pagos pelos outros canais de difusão que, por sua vez, proliferam: canais de televisão, Internet, eletrônica, chaves USB, concertos, rádios, streaming e downloads, ringtones para celulares, músicas de filmes, spots publicitários, cartões com chip de memória, secretárias eletrônicas, etc $262 "$.

260 Lei n. ${ }^{\circ}$ 9.610/98: "Art. 5, X - produtor - a pessoa física ou jurídica que toma a iniciativa e tem a responsabilidade econômica da primeira fixação do fonograma ou da obra audiovisual, qualquer que seja a natureza do suporte utilizado."

261 Tradução livre de "il contratto di edizione per opere musicali, specie quello usato comunemente per le opere di musica leggera e di musica di commento ad opere audiovisive, è contratto che intende cedere in proprietà all'editore tutti $i$ diritti di utilizzazione dell'opera, senza limiti temporali o spaziali, e prevede a carico di quest'ultimo anche un obbligo formale di pubblicazione per le stampe, limitato normalmente ad un numero di copie che con la sua modestia dimostra la sua valenza non commerciale" (DE SANCTIS e FABIANI, I contratti..., p.252).

262 MORTAIGNE, Véronique. Num mercado do disco acidentado, a edição musical está com boa saúde. Tradução de NEUFVILLE, Jean-Yves. Le Monde, Paris, 29 set. 2007. Disponível em: < http://noticias.uol.com.br/ midiaglobal/lemonde/2007/09/29/ult580u2688.jhtm>. Acesso em: 1. ${ }^{\circ}$ out. 2007. Tal reportagem informa sobre a satisfação dos editores com a profusão de suportes e demonstra, através de dados, que a atividade 
A edição, assim, constitui interessantíssima atividade que na prática consiste em administrar as diversas utilizações dos fonogramas (especialmente contratos de licenciamento e autorização, bem como arrecadação de valores oriundos da execução pública), assim como definir e executar as estratégias de marketing com vistas a gerar cada vez mais utilizações da obra musical.

A indústria fonográfica moderna desenvolve as atividades de produção (para assim adquirir os direitos conexos respectivos) e de edição (para explorar - ou adquirir - o direito de autor).

\subsection{A EXPLORAÇÃO DO MERCADO FONOGRÁFICO DIGITAL PELA INTERNET}

\subsubsection{O Desenvolvimento de Tecnologias de Compressão de Dados}

No âmbito da música, já digitalizada desde o surgimento do Compact Disc, foram iniciados estudos acerca de tecnologias de compressão de seus respectivos dados, visando possibilitar o maior armazenamento na menor quantidade possível de bytes. Tais estudos foram realizados sob a égide do projeto EUREKA ${ }^{263}$, rede pan-européia que financia e coordena os esforços dos governos e das empresas para a pesquisa e o desenvolvimento.

Dentro desse contexto, diferentes instituições foram estimuladas a criar grupos de cientistas que, coordenadamente, desenvolveram o programa de pesquisa para a transmissão de rádio e televisão digital, resultando nos padrões de compressão MPEG (Moving Picture Experts Group), o qual, no que diz respeito ao áudio, recebeu, após sua denominação, a expressão Audio Layer.

de edição está mais interessante aos investidores do que a de produção musical, pela alta lucratividade que proporciona: "Uma prova disso são as intenções atribuídas ao fundo de investimento Terra Firma, que acaba de comprar a 'major' do disco britânica EMI. Em outubro, o Terra Firma deverá confirmar ou não a sua intenção de se livrar da atividade relativa aos discos da EMI, para ficar apenas com a edição ou o publishing. O cálculo é simples, resume Fabrice Nataf, o CEO da filial francesa da EMI Publishing (1,5 milhão de títulos no seu catálogo, faturamento de 40 milhões de euros - R \$ 104 milhões - na França). 'A EMI Publishing representa 25\% do faturamento do grupo EMI, mas 75\% dos seus lucros"'.

263 "EUREKA is a pan-European network for market-oriented, industrial R\&D. Created as an intergovernmental Initiative in 1985, EUREKA aims to enhance European competitiveness through its support to businesses, research centres and universities who carry out pan-European projects to develop innovative products, processes and services." (Disponível em: <http://www.eureka.be/about.do>. Acesso em: 4 abr. 2007). 
O padrão MPEG - Audio Layer 2, também conhecido como "Musicam", foi lançado pelo Deutsche Forschungs- und Versuchsanstalt für Luft- und Raumfahrt e foi o escolhido para servir de base para a continuidade no aprimoramento das tecnologias de compressão.

Na seqüência, a Philips, o CCETT (Centre Commun d'Etudes de Télévision et Télécommunications), o Institut für Rundfunktechnik e o Fraunhofer-Gesellschaft ${ }^{264}$ desenvolveram, simultaneamente, o que viria a ser o MPEG - Audio Layer 3, ou simplesmente MP3 ${ }^{265}$, cujos leitores (decoders) foram lançados na metade da década de 1990, com o que tal popular padrão de compressão sonora revolucionou a música, principalmente por possibilitar a gravação de centenas de músicas em um meio físico Compact Disc e a transmissão e troca de arquivos pela internet.

Importante notar que, embora o MP3 seja a tecnologia de compressão mais popular e que se tornou sinônimo tanto de "pirataria" on-line quanto da propalada "Revolução do MP3"266, não se trata necessariamente do melhor formato, já que existem outros, a exemplo do AAC (Advanced Audio Codec), os quais utilizam ainda menor quantidade de bytes para a compressão do arquivo digital de músicas, com manutenção da qualidade sonora ${ }^{267}$.

Foi nessa mesma época, em 1995, que no Brasil se iniciou a possibilidade de acesso à internet "comercial", por meio dos provedores de acesso, que possibilitavam a

264 A patente do MP3 pertence ao Fraunhofer IIS (o Instituto de Circuitos Integrados da FraunhoferGesellschaft), que o licencia aos interessados, muito embora empresas como a Thomsom, Alcatel-Lucent e Texas MP3 também possuam certificados de patente sobre variações do padrão, de modo que existe incerteza quanto à sua real titularidade.

265 "Tecnicamente per creare um file MP3 si eseguono due operazioni:il ripping e l'encoding. La prima fase consiste nel trasferire un brano dal supporto in cui è registrato nella memoria del computer in formato .wav (nel sistema operativo Windows) o .aiff (in Macintosh). La seconda riguarda sostanzialmente la codifica del file nell'estensione MP3 secondo le regole della psicoacustica già evidenziate. Il file MP3 si compone di una serie di frame, ciascuno identificato da un header, indicante l'insieme di dati, ossia delle informazioni sul regime dei diritti che viaggiano con il file e che indicano i titolari del diritto d'autore e dei diritti conessi, il titolo del brano, l'anno di registrazione ed altri dati per l'identificazione del brano musicale." (De ANGELIS, La tutela giuridica..., p.13).

266 Para Deborah De Angelis "la caratteristica che ha segnato la rapida e capillare diffusione di questo formato di compressione, tanto che si è arrivati a parlare di MP3 revolution, come sinonimo del nuovo trend sociale della diffusione della musica on line ..." (De ANGELIS, La tutela giuridica..., p.13).

267 Muito embora há quem diga que a qualidade dos sons comprimidos digitalmente é inferior à do CD ou mesmo do disco de vinil. 
conexão pela linha telefônica, sendo necessária a instalação de um modem $^{268}$ cuja velocidade alcançava $56 \mathrm{kbps}^{269}$, o máximo que poderia ser tecnicamente atingido por uma linha analógica e única opção aos que desejassem se conectar à rede.

Assim, mesmo com as tecnologias de compressão, a exemplo do MP3, era difícil, para o usuário, receber a transmissão de uma simples música, missão que podia levar horas. Difícil, mas não impossível. O fato é que o download ${ }^{270}$ de obras musicais passou a ser cada vez mais freqüente, já que muitos dos usuários conectavam seus microcomputadores à internet durante toda a noite, vez que no modelo vigente de tarifação acabavam por pagar apenas um único pulso telefônico.

Logo após a virada do milênio, passou a ser oferecido, no Brasil, o acesso em "banda larga"271, por meio de linha telefônica digital, que garantia - e garante -, no mínimo, o dobro de velocidade na conexão, mas que representou muito mais do que tal proporção no aumento dos downloads de obras musicais ${ }^{272}$.

268 "A palavra "modem" é uma contração das palavras modulador-demodulador. O modem é usado para enviar dados digitais através de uma linha telefônica. O modem que envia modula os dados em um sinal compatível com a linha telefônica, e o modem que recebe demodula o sinal de volta aos dados digitais. Modems sem fio convertem dados digitais em sinais de rádio e vice-versa. Os modems foram criados na década de 60 como uma forma de permitir aos terminais conectarem-se a computadores através de linhas telefônicas". (BRAIN, Marshall. "Como funcionam os modens" em HowStuffWorks. Verbete. Disponível em: <http://informatica.hsw.uol.com.br/modem1.htm>. Acesso em: 13 out. 2007).

269 "kbps corresponde a um 'kilobit por Segundo', sendo o kilobit uma unidade de memória de computador com capacidade igual a 1024 caracteres. Entretanto, quando utilizado com o "k" em letra minúscula significa 1000 caracteres" (DOWNING, Douglas. Dictionary of Computer and Internet Terms. 6.ed. New York: Barron's, 1998. p.255-257).

270 A definição que o Dicionário Aurélio dá a download é "1. Numa rede de computadores, obtenção de cópia, em máquina local, de um arquivo originado em máquina remota". O mesmo dicionário indica que "fazer um download" significa "baixar" um arquivo ("4. Inform. Receber, através da rede de computadores cópia de um arquivo localizado em máquina remota").

271 Denomina-se acesso em "banda larga" a conexão à internet em velocidade superior àquela possibilitada pelo modem (56kbps). As tecnologias mais utilizadas são o ADSL, ISDN, Cable modem (por intermédio da mesma rede da TV a cabo) e wireless (sem fio).

272 Segundo informa a ABPD (Associação Brasileira de Produtores de Discos): "Em 2005, houve um aumento significativo nas vendas de computadores, MP3 players e também no número de usuários de Internet por banda larga, o que favorece em muito os downloads ilegais de conteúdo protegido por Direito Autoral de qualquer natureza utilizando aqueles sistemas." (ABPD. Publicação anual do mercado fonográfico ABPD 2005. Rio de Janeiro, 2006. p.16). 
Nessa mesma época, no Brasil, a questão passou a despertar o interesse dos estudiosos do direito. A ABPI - Associação Brasileira da Propriedade Intelectual, em sua Assembléia Geral anual, aprovou por unanimidade resolução intitulada "O mp3 e a proteção dos direitos autorais", em que dispôs que "os arquivos em formato MP3, por si só, não representam nenhuma violação a direitos de autor, sendo tão-somente um novo formato de gravação de obras musicais que possibilita o armazenamento de um grande número de músicas utilizando pouca memória" e concluiu com o reconhecimento de que "muitas vezes a utilização de arquivos em formato MP3 pode ser benéfica aos interesses do autor na difusão e divulgação de sua obra. A ele, porém, deve ser dado o direito de decidir, tal como reza nossa legislação autoral em vigor"273.

Conforme já visto no capítulo anterior, a indústria fonográfica, dominada pelas chamadas majors, pautava-se num modelo oligopolista e centralizador, com atuação em todas as esferas da cadeia musical. Tinha lançado o Compact Disc poucos anos antes e auferia fantásticos lucros, já que impunha aos consumidores não somente o que deveria ser consumido, mas também a que preço seria vendido.

Assim, com o surgimento da possibilidade de os usuários "baixarem"274 as músicas da internet as gravadoras se depararam com uma situação desconhecida, sem qualquer domínio da situação, visto que muitos sítios ofereciam as músicas gratuitamente, listadas de maneira individual, de modo que o usuário podia escolher, dentre as constantes em um álbum, somente aquela que quisesse descarregar em seu microcomputador e escutar. Em paralelo, diversos sistemas profissionais foram desenvolvidos e seu uso passou a ser oferecido como serviço aos usuários da internet. Empreendedores buscavam meios de lucrar com o limbo normativo daquela fase inicial da internet, não necessariamente se preocupando com os direitos autorais.

273 ABPI - Associação Brasileira da Propriedade Intelectual. Resolução: O MP3 e a proteção dos direitos autorais. Revista da ABPI - Associação Brasileira da Propriedade Intelectual, n.49, p.53-54, nov./dez. 2000.

274 Baixar, segundo o dicionário Houaiss, é "transferir (software ou dados provenientes de um computador) para o computador que está sendo operado pelo usuário, estando os dois computadores conectados por linha telefônica ou por outro canal de telecomunicações" (DICIONÁRIO HOUAISS. Baixar. Disponível em: $<$ http:/houaiss.uol.com.br/busca.jhtm?verbete=baixar\&stype=k>. Acesso em: 7 abr. 2007). 
Paralelamente, teve início a possibilidade de o usuário somente escutar suas músicas através da rede, pelo chamado streaming ${ }^{275}$, tecnologia que possibilitou a criação das rádios on-line, cabendo notar que, nesse caso, há tão-somente o armazenamento temporário do pacote de dados recebidos no microcomputador do usuário.

Todas essas inovações representaram um impacto negativo muito forte na indústria fonográfica, imediatamente posterior à constatação de que a pirataria física de CDs estava atrapalhando, e muito, seus negócios, e era nessa direção - da repressão dos "piratas" de CDs - que os esforços repressivos estavam focados, mediante cinematográficas operações de busca e apreensão.

A indústria fonográfica, conforme já tratado no capítulo anterior, sempre atuou sob padrões globais. E foi, também, em termos globais que ignorou a novel mídia no seu ponto principal: a mudança de hábitos provocada nos consumidores e no mercado musical como um todo, que de verdadeiros reféns, pela atitude passiva que deveriam assumir, obrigados que eram a consumir tão-somente o que era decidido por alguns executivos, passaram a ter o poder de decisão, em vista da interatividade possibilitada pelos avanços tecnológicos.

Não deram início, as gravadoras, por si, a um modelo de comercialização de músicas pela internet de forma que as remunerasse e aos demais titulares de direitos autorais, nem tampouco autorizaram terceiros habilitados que os promovessem, assim como ignoraram as rádios on-line. $\mathrm{O}$ resultado foi que perderam o controle da situação, dando o início ao fim do modelo operante e o surgimento da atual crise dos direitos autorais na música, por muitos tida como a maior já havida.

O usuário que pretende tomar contato com a música pela internet o faz, principalmente, por quatro maneiras: a) pela aquisição de meios físicos de fixação (normalmente Compact Discs) através de sítios de comércio eletrônico; b) por meio de downloads a partir de sítios da internet; c) pelas rádios on-line e d) pela disseminação entre os usuários de músicas, pelo compartilhamento por redes ponto-a-ponto, via e-mail ou servidores $f t p$.

275 "Entrega de sinais de áudio ou vídeo em tempo real, sem esperar o descarregamento do arquivo inteiro antes de executá-lo." (DOWNING, Dictionary of Computer..., p.444). 


\subsubsection{A Aquisição de CDs pela Internet}

No início da internet comercial, a indústria fonográfica passou a oferecer seus produtos (CDs, meios físicos) aos consumidores nos estabelecimentos que praticam o chamado comércio eletrônico ou e-commerce, sendo pioneiras no oferecimento de produtos fonográficos as internacionais amazon.com e CDnow.com ${ }^{276}$.

O funcionamento da operação de compra e venda de CD pela internet se dá tal como no sistema tradicional, praticado nas lojas "reais", com a diferença que o consumidor escolhe o CD sem ter a necessidade de deslocar-se ao estabelecimento comercial, bem como dispõe de acesso a maior quantidade de álbuns, uma vez que o estabelecimento online não necessita ter o produto em estoque, podendo adquiri-lo perante os distribuidores de acordo com as vendas efetuadas.

Esse meio de vendas é igualmente interessante pela eficiência que promove, uma vez que torna desnecessária a onerosa manutenção de uma loja física. Com a economia proporcionada pela redução de custos, os sítios on-line compensam a ausência do auxílio pessoal que um funcionário qualificado em música pode prestar com a oferta de sofisticados sistemas de buscas, que orientam o usuário na seleção do álbum desejado e auxiliam na descoberta de músicas e estilos musicais que possam agradá-lo.

O consumidor, após selecionar o que pretende adquirir, paga a conta por transação on-line via cartão de crédito, transferência bancária on-line ou ainda pela impressão de bloqueto bancário e posterior pagamento em agência bancária ou lotérica, no caso do Brasil. A partir da confirmação do recebimento, a loja virtual providencia a remessa ao endereço do adquirente, pelo correio ou outro serviço de transporte.

Esse meio de aquisição, por si só, representa notável avanço proporcionado pela tecnologia e foi responsável pela introdução de diversos questionamentos sobre aspectos contratuais, tributários e consumeristas. É, ainda, muito utilizado para a compra de música gravada em meios físicos. São exemplos de sucesso brasileiros na venda de meios físicos

276 A CDnow foi fundada em 1994 e foi, no início da internet comercial e durante alguns anos, o mais popular sítio de música da internet, já que oferecia um interessante sistema de avaliação, qualificação e comentários sobre músicas e discos que captava as opiniões dos usuários. Em 2000 foi adquirida pela gigante de mídia Bertelsmann, proprietária da BMG que, por sua vez, em 2002 se fundiu com a Sony, criando a Sony BMG. Em 2002 a gigante do varejo online Amazon passou a operar o site CDnow.com, entretanto com seu próprio lay out e sistema de vendas. 
pela internet os sítios de comércio eletrônico das grandes redes de livrarias e de "magazines" virtuais.

Tal forma de distribuição de músicas não configura qualquer questão aos direitos autorais, em se considerando que os CDs adquiridos são aqueles legalmente autorizados pelos titulares e não cópias contrafeitas, com a contraprestação autoral devidamente recolhida e supostamente distribuída a quem de direito.

Por outro lado, é comum a oferta de CDs piratas pela internet, por meio de $\operatorname{spams}^{277}$, sítios hospedados temporariamente em servidores gratuitos no exterior e sítios de leilão virtual. Tal comercialização, propositalmente feita às escondidas, infringe a lei autoral e penal.

Dados da APDIF (Associação Protetora dos Direitos Intelectuais Fonográficos) dão conta de que, em 2004, ela notificou 4.125 sítios que "disponibilizavam de forma ilegal conteúdo protegido pelo Direito Autoral", sendo que 4.113 foram removidos e 44\% se dedicavam às vendas de CDs falsificados 278 .

\subsubsection{A Distribuição de Obras Musicais Digitais pelos Digital Music Shops (ou as Lojas Virtuais)}

Enquanto no início da internet comercial os usuários em geral utilizavam a rede para escolher ou adquirir seus discos em meios físicos, alguns internautas ${ }^{279}$ travavam contato com a música digitalizada e comprimida, por meio da interface multimídia da rede, a World Wide Web ${ }^{280}$, em que, mediante o acesso aos sítios que ofereciam os arquivos,

277 Mensagens eletrônicas (e-mails) não-solicitadas. Para aprofundamento, vide SILVA NETO, Amaro Moraes e. O spam à luz do direito brasileiro (uma visão geral). Disponível em: $<$ http://www.internetlegal.com.br/artigos/>. Acesso em: 9 ago. 2007. São diversos os projetos de lei que tramitam no Congresso Nacional que buscam regular o envio de mensagens eletrônicas. Dentre outros: PL 2.186/03, PL 2.423/03, PL 3.731/04, PL 3.872/04, PL 1.227/07, PL 2.196/03, PL 4.562/04, PL 169/07. Fonte: <http://www.internetlegal.com.br/projetos/camara/>. Acesso em: 9 ago. 2007.

278 Fonte: sítio da SOCINPRO - Sociedade Brasileira de Administração e Proteção de Direitos Intelectuais. Disponível em: http://www.socinpro.org.br/piratinternet.htm>. Acesso em: 9 ago. 2007.

279 Cf. Dicionário Aurélio: "1. Usuário da Internet, rede mundial de computadores. 2. Restr. Usuário intensivo da rede Internet, que ocupa grande parte de seu tempo explorando os recursos por ela oferecidos."

280 Cf. Dicionário Aurélio: "Web: S. f. Inform. 1.Recurso ou serviço oferecido na Internet (rede mundial de computadores), e que consiste num sistema distribuído (q. v.) de acesso a informações, as quais são apresentadas na forma de hipertexto, com elos entre documentos e outros objetos (menus, índices), localizados em pontos diversos da Rede". 
escolhiam as faixas musicais que lhes agradavam e as transferiam ao seu microcomputador, sem o pagamento de contraprestação.

Não demorou muito para que alguns vislumbrassem na situação verdadeira oportunidade de negócios, pelo que passaram a surgir sítios que ofereciam as faixas musicais sob pagamento de contraprestação, mas também sem qualquer vinculação - ou autorização dos titulares de direitos autorais, o que, além do ilícito civil, constituía crime previsto no art. 184 do Código Penal281.

A indústria fonográfica passou à reação, por meio de notificações aos titulares dos sítios, sendo que, na maioria das vezes, obtinha êxito, conforme o quadro a seguir:

QUADRO 1 - COMBATE À PIRATARIA NA INTERNET - ANOS 2000

\begin{tabular}{|l|l|l|l|l|l|}
\hline \multicolumn{1}{|c|}{ APREENSÕES } & 2000 & 2001 & 2002 & 2003 & 2004 \\
\hline Páginas Notificadas & 3766 & 8897 & 9708 & 8782 & 4125 \\
\hline Páginas Removidas & 2785 & 8694 & 9458 & 8687 & 4113 \\
\hline
\end{tabular}

FONTE: APDIF - Associação Protetora dos Direitos Intelectuais Fonográficos. Disponível em: $<$ http://www.socinpro.org.br/piratinternet.htm>. Acesso em: 9 ago. 2007.

Observe-se que não necessariamente os sítios notificados praticavam o comércio de música, pois essas estatísticas também abrangem aqueles que as ofereciam gratuitamente.

Por outro lado, são diversos os sítios que atualmente oferecem as músicas sob autorização de seus titulares, assim como surgiram novas formas de licenciamento e de contato entre os compositores e intérpretes e o público.

A internet, pelo crescente aumento do número de usuários, se mostrou um importante meio de negócios. No caso específico da música, em vista do aprimoramento das tecnologias de digitalização e compressão, do aumento da oferta de acesso à banda larga e da comodidade em se localizar as músicas preferidas no conforto dos lares e imediatamente tê-las disponíveis, fez com que iniciativas de comercialização se revelassem um sucesso.

281 Código Penal, "Art. 184. Violar direito autoral: Pena - detenção de três meses a um ano, ou multa de $\mathrm{Cr} \$ 2.000,00$ a Cr\$10.000,00. $\S 1 .^{\circ} \mathrm{Se}$ a violação consistir em reprodução, por qualquer meio, com intuito de lucro, de obra intelectual, no todo ou em parte, sem autorização expressa do autor ou de quem o represente, ou consistir na reprodução de fonograma ou videofonograma, sem a autorização do produtor ou de quem o represente: Pena - reclusão, de um a quatro anos, e multa, de Cr\$10.000,00 (dez mil cruzeiros) a Cr\$50.000,00 (cinqüenta mil cruzeiros).

$\S 2{ }^{\circ} \mathrm{Na}$ mesma pena do parágrafo anterior incorre quem vende, expõe à venda, aluga, introduz no País, adquire, oculta, empresta, troca ou tem em depósito, com intuito de lucro, original ou cópia de obra intelectual, fonograma ou videofonograma, produzidos ou reproduzidos com violação de direito autoral. 
O oferecimento de músicas pela internet igualmente representa redução de custos e eficiência, o que pode significar maior lucro ou, dependendo do enfoque estratégico do operador, o repasse da redução de custos para o consumidor, gerando ganho em escala, com margem de lucro menor porém atingindo maior número de pessoas.

A indústria fonográfica, entretanto, demorou para perceber a importância da internet como canal de vendas aos consumidores e se recusava a licenciar as músicas sob sua titularidade aos que de forma pioneira ofereciam músicas pela internet. Somente após a profusão de sítios ilegais contendo arquivos musicais foi que decidiu oferecer ao público consumidor uma opção legítima de acesso aos seus catálogos. Entretanto, temerosa quanto à possibilidade de aumentar ainda mais a infração aos direitos autorais sob sua titularidade, somente após desenvolver medidas tecnológicas de proteção (o chamado DRM - Digital Rights Management) é que passou a autorizar a disseminação das obras musicais por meio da rede mundial.

O DRM (ou gestão digital de direitos) na música consiste, basicamente, na conjunção entre contrato de licença e dispositivos tecnológicos hábeis a implementar as condições estipuladas pelo titular de direitos autorais, de obra musical ou fonograma. Existe, a partir disso, uma série de possibilidades como, por exemplo, vedar o acesso a determinada faixa musical a quem eventualmente não pagou o preço pedido pelo titular ou mesmo impedir a cópia ou ainda ambos em conjunto.

Esse tema, que será tratado em tópico próprio no capítulo terceiro, é de extrema atualidade nos direitos autorais, e tem causado muita repercussão. Os titulares de direitos autorais, notadamente a indústria fonográfica, nutrem grande expectativa por tais métodos, já que lançam mão justamente da técnica para combater os desafios da técnica, representados pelas infrações.

Outrossim, os números do mercado musical on-line no Brasil são vultosos. Informa a ABPD - Associação Brasileira dos Produtores de Discos que "aproximadamente 1,1 bilhão de arquivos musicais foram baixados no Brasil em 2005. Cerca de 3 milhões de pessoas fazem downloads de música no País, a maioria deles ilegal"282.

282 ABPD, Publicação anual..., p.20. O mesmo estudo aponta que "8,2\% da população pesquisada, que corresponde cerca de 2,9 milhões de pessoas baixaram música na internet no ano de 2005, contabilizando quase 1,1 bilhão de canções sendo baixadas da rede mundial de computadores, a grande maioria oriunda das redes de compartilhamento de arquivos (Peer to Peer). Um número assustador e de prejuízos incalculáveis para o setor fonográfico como um todo: gravadoras, artistas, compositores, músicos, etc. Se esses downloads fossem feitos de forma legalizada, o setor teria arrecadado mais de R\$ 2 bilhões, ou 
O fato é que o mercado de oferta de música digital on-line se expandiu e, conforme dados da IFPI, a International Federation of the Phonographic Industry (Federação Internacional da Indústria Fonográfica), em 2006 estavam ativos em torno de 500 serviços on-line tidos como legais em mais de 40 países, sendo que 12 no Brasil 283.

Conforme já visto, tais sítios distribuem a obra musical digitalizada. São duas as possibilidades acerca da natureza do negócio jurídico praticado no "comércio eletrônico" de música digitalizada pela internet: i) a primeira é no sentido de que ocorre negócio jurídico de compra e venda, pelo pagamento do preço e recebimento, por transferência, de arquivo digital contendo a música, a partir dos computadores da "loja virtual".

A segunda possibilidade leva ao entendimento de que se trata de uma prestação de serviços, sendo a "loja virtual" uma simples intermediária que se encarrega de disponibilizar os meios de armazenamento, de pesquisa e de recebimento dos valores. Seria, a função da "loja virtual" de natureza prestacional pelo fato de que os titulares dos direitos referentes ao fonograma são os que licenciam a utilização diretamente ao usuário.

\subsubsection{Sítios nacionais de distribuição de música}

Os sítios de distribuição de música sediados no Brasil, à exceção daquele oferecido pela gravadora Trama ${ }^{284}$, são similares em seus modelos de funcionamento. Cabível a

seja, 3 vezes mais do que o montante faturado pelo mercado oficial no ano passado com a venda de CDs e DVDs originais, que foi de $\mathrm{R} \$ 615,2$ milhões. Foi apresentado pela pesquisa, também, que deste universo de $8,2 \%$ que utilizam a rede para baixar músicas, $4,2 \%$ gravou em $\mathrm{CD}$ as músicas baixadas da internet, o que correspondeu a mais de 13 milhões de CDRs gravados, somente no último trimestre de 2005. O que representaria aproximadamente 52 milhões de CDs gravados no último ano, isto é, $13 \%$ a mais que os CDs originais vendidos durante os 12 meses de 2005".

283 IFPI - International Federation of the Phonographic Industry. IFPI 2007: Record Industry in Numbers. Londres: IFPI, 2007. p.75.

284 A gravadora independente Trama foi constituída já sob a égide da Internet e assimilou rapidamente as oportunidades existentes. Oferece a plena "degustação" das faixas musicais de seus artistas bem como a possibilidade de download de músicas gratuitas, assim como perfaz a venda de faixas musicais on-line, álbuns, DVDs e CDs. A visão diferenciada da gravadora está bem demonstrada no manifesto firmado pelo seus presidentes em 19/10/2004: "Manifesto Trama. Os presidentes André Szajman e João Marcello Bôscoli apresentam a carta de intenções da gravadora, com suas crenças e propostas. O objetivo desse Manifesto foi criar um documento mutável que refletisse nossas crenças e propostas. Para isso, mergulhamos em um processo intenso, onde depois de seis anos de fundação, revisitamos, questionamos e acrescentamos novas idéias à nossa TRAMA. Nós não podemos aceitar que nossos valores se diluam com o crescimento da nossa empresa. O que você vai ler a seguir é uma grande parte dessa busca por inovação, renovação e movimento.

André Szajman e João Marcello Bôscoli

MANIFESTO TRAMA 
análise pontual. Tome-se, por exemplo, o portal brasileiro "iMusica", cujo catálogo também consta de outros portais de oferta de músicas por download ${ }^{285}$.

Nós da Trama acreditamos que:

- A vida sem música é um erro.

A música é uma crônica de sua época. Os interesses comerciais não podem definir a música. A música é definida pelas pessoas e pelo seu tempo.

- Música é nossa Essência.

Acreditamos na capacidade da música emocionar e transformar pessoas. E, além disso, acreditamos na arte que sensibiliza mas que também desperta consciência e senso crítico. Acreditamos que a arte é um caminho para o desenvolvimento político e social do país.

- Devemos preservar e valorizar as relações humanas.

Somos indivíduos antes de tudo. O caminho para uma relação saudável entre artistas, produtores, distribuidores, difusores e consumidores é a busca constante pela manutenção da conexão entre o que se acredita como pessoa e o que se pratica como profissional ou empresário (valores éticos e estéticos).

Assim como na educação e na saúde, a música não pode ser exercida por pessoas descomprometidas, ou que não tenham ligações emocionais e filosóficas com o que fazem. Acreditamos que é preciso ter sinceridade, ética e emoção.

- A tecnologia existe para servir a música e não o contrário.

Acreditamos em novas e tradicionais tecnologias, que criam novas maneiras de trabalhar, produzir, pesquisar, ver e ouvir.

A tecnologia digital (Internet, celular, TV, etc.) é a maior difusora de música da história da humanidade, convergindo divulgação e consumo em tempo real.

- Propósito Original.

Não havia uma gravadora no início dos tempos e um artista foi pedir um emprego. Havia sim um artista e ao redor dele se construiu um negócio. Toda vez que esta direção for invertida teremos problemas, pois o propósito é e sempre será a MÚSICA.

Por tudo isso, nós da Trama nos propomos a:

- Utilizar a música como principal critério de decisão. Música é o centro do nosso universo, nossa prioridade, inspiração e meio de vida.

Estimular um movimento de transformação da indústria que dê à música sua devida importância cultural e mercadológica - dentro do negócio, respeitando seus valores e propósitos originais.

- Reunir pessoas que acreditem nas mesmas coisas que nós.

Investir no artista que cria sua obra, acredita nela e constrói uma carreira sustentável; que realiza todo o seu potencial de mercado através do talento e mérito. Isso para nós é sucesso.

- Incentivar e apoiar o artista nacional para que seu trabalho tenha forma, acabamento e linguagem reconhecíveis internacionalmente.

Fortalecer e estimular a atuação da música independente.

Manter uma constante busca por inovação, renovação, consolidação e perpetuação das obras artísticas brasileiras.

- Utilizar a tecnologia digital como facilitadora da prospecção artística, da criação, produção, interação, promoção e distribuição de música.

Criar relações baseadas no respeito, liberdade e compartilhamento de visão ética e estética de uma forma consensual, nunca imposta.

- Valorizar as relações humanas: artistas, veículos e consumidores, todos nós somos indivíduos antes de tudo. Manter relações transparentes e verdadeiras.

Somos um movimento de MÚSICA!" (Disponível em: <http://rama.uol.com.br/portalv2/noticias/ index.jsp?id=9385>. Acesso em: 14 out. 2007).

285 "Nosso catálogo é disponibilizado em uma rede de lojas virtuais, tendo como parceiros os principais portais do país, como a MSN, Yahoo, Americanas.com e BRTurbo". Informa-se, ainda, que tal serviço funciona desde 2000 e que a "iMusica tem acordos de licenciamento com mais de 200 gravadoras e distribuidoras, entre as quais Warner Music, EMI Music, Deckdisc, Trama, Indie Records e Biscoito Fino, além de convênio com ABEM e ABER, principais associações de editoras do país." (Disponível em: <http://www.imusica.com.br/Corp.aspx?f=QuemSomos>. Acesso em: 10 ago. 2007). 
Para se ter acesso à música, é necessário providenciar a instalação de um software denominado download manager, o preenchimento de um cadastro com dados pessoais e a determinação de senha de acesso, cuja conclusão só se dará caso o usuário "clique 286 " no pequeno quadrado correspondente à frase "declaro que li e aceito os Termos de Uso do site".

Tal documento, denominado "Termos e Condições de Uso do portal iMusica", é, na verdade, um contrato por adesão, no qual o usuário tem somente a opção de aceitar suas cláusulas ou não, não lhe sendo concedida qualquer possibilidade de modificação. O momento da contratação se dá pela aceitação dos termos lá contidos, pelo já mencionado "clique", o que a doutrina estrangeira denomina click-wrap ${ }^{287}$.

O primeiro parágrafo da cláusula primeira do contrato informa ao usuário a respeito da utilização de dispositivo de $\mathrm{DRM}^{288}$ nas músicas. A cláusula terceira, que supostamente versaria sobre os "direitos dos usuários", dispõe sobre diversas vedações às quais eles se

286 Cf. Dicionário Aurélio, clicar significa " 1. Inform. Apertar e soltar o botão do mouse, sem mover este, produzindo um clique (1) característico que, ger., indica a seleção de um objeto ou a ativação de um programa ou recurso de programa".

287 "Um contrato 'click-wrap' é um contrato formado integralmente num ambiente on-line como a Internet, o qual determina os direitos e obrigações entre as partes. O termo 'click-wrap' é derivado do fato de que tais contratos on-line geralmente requerem o clique do mouse num ícone ou botão na tela para assinalar a aceitação do contrato pela parte. Entre outras coisas, contratos 'click-wrap' são utilizados para: (1) estabelecer os termos para download e uso de software pela internet; (2) determinar os termos de uso de um sítio, isto é, as regras pelas quais os usuários podem acessar o sítio ou porção do sítio tal qual um chat ou serviço de mensagens; e (3) estabelecer os termos para a venda de bens e serviços on-line. Tradução livre de "\{1\} A 'click-wrap agreement' is an agreement, formed entirely in an online environment such as the Internet, which sets forth the rights and obligations between parties. The term 'click-wrap' is derived from the fact that such online agreements often require clicking with a mouse on an on-screen icon or button to signal a party's acceptance of the contract. Among other things, clickwrap agreements are used to: (1) establish the terms for the download and use of software over the Internet; (2) set forth a Web site's Terms of Service, i.e., the rules by which users may access the Web site or a portion of the Web site such as a chat or message service; and (3) establish the terms for the sale of goods and services online". (BUONO, Francis M. e FRIEDMAN, Jonathan A. Maximizing the Enforceability of Click-Wrap Agreements. Journal of Technology Law \& Policy, University of Florida Levin College of Law, v.4, n.3, p.1, 1999). Disponível em: <http:/grove.ufl.edu/ techlaw/vol4/ issue3/friedman.html\#en*>. Acesso em: 14 out. 2007.

288 "O usuário entende e concorda que a iMusica inclua componentes de segurança que permitem proteger a informação digital podendo limitar seu uso e acesso de forma que os arquivos de música digital só podem ser usados conforme autorizam as regras determinadas pela iMúsica e/ou artistas e gravadoras. Os serviços oferecidos pela iMusica só estão disponíveis no Brasil." (Disponível em: $<$ http://www.imusica.com.br/TermosDeUso.aspx>. Acesso em: 19 ago. 2007). 
sujeitam, ressaltando o caráter de uso pessoal que as informações (músicas, no caso) deverão ter. ${ }^{289}$

Mediante a cláusula quarta, "Da Licença e Limitações de Uso", é concedida "aos seus usuários uma licença não-exclusiva, intransferível, e revogável para que os mesmos possam usar o conteúdo iMusica conforme as limitações seguintes:". Tais limitações se dividem em "usos permitidos $290 "$ e "usos não-permitidos"291, sendo que, a exemplo da cláusula terceira, nas situações em que supostamente os usos seriam "permitidos" estão dispostas mais vedações do que propriamente permissões ${ }^{292}$, ao mesmo tempo em que se transfere e

289 "A iMusica e todos os materiais disponíveis no Portal, incluindo mas não se limitando a, imagens, software, texto, vídeo-clipes e músicas em formato digital são disponibilizados somente para uso pessoal. Você usuário concorda que ao adquirir licenças de arquivos de música digital, o faz para seu próprio uso pessoal e entretenimento, não visando a sua redistribuição ou compartilhamento com terceiros.

A aquisição de qualquer conteúdo disponibilizado pela iMusica não confere ao usuário qualquer direito sobre a reprodução ou propriedade do mesmo. Você está proibido de distribuir, trocar, modificar, vender ou re-vender, ou transmitir a qualquer outra pessoa qualquer material contido na iMusica, incluindo mas não se limitando a qualquer texto, imagens, áudio, e vídeo, para qualquer finalidade ou propósito.

Você concorda em cumprir as regras e políticas estabelecidas periodicamente pela iMusica." (Disponível em: <http://www.imusica.com.br/TermosDeUso.aspx>. Acesso em: 19 agosto 2007).

290 "Usos permitidos: As músicas adquiridas por download através do iMusica podem ser tocadas indefinidamente (não há limite de execução). Porém, as músicas não podem ser ouvidas em outro computador que não o que realizou o download da licença de uso. As músicas podem ser copiadas ou transferidas para outro computador, dentro dos limites impostos pela gravadora, para que ela toque, protegendo os direitos autorais. Alguns arquivos disponibilizados gratuitamente funcionam indefinidamente, mas outros têm uma data de vencimento ou validade e não funcionam após determinado número de dias. É permitida ainda a transferência dos arquivos de música para outros equipamentos (players de MP3) portáteis que suportem o formato Windows Media Audio (WMA). Você também tem o direito de copiá-las em CDs graváveis para uso pessoal (caso exista um gravador de CD acoplado a seu computador), dentro dos limites impostos pela gravadora, e ouvir em qualquer aparelho de CD comum. Não é permitida a gravação de CDs a partir de músicas licenciadas gratuitamente a titulo promocional. A limitação da emissão de licenças e cópias de CDs graváveis varia de acordo com cada gravadora que tem suas próprias regras, portanto a iMusica recomenda que o usuário esteja atento aos termos de cada uma." (Disponível em: $<$ http://www.imusica.com.br/TermosDeUso.aspx>. Acesso em: 19 ago. 2007).

291 "Usos Não-permitidos: Qualquer uso das gravações disponibilizadas pelo iMusica diferentemente de como permitido acima é uma violação do direito autoral em tal música, sendo expressamente proibido. Além das vedações acima, é proibido ainda realizar engenharia reversa a fim de burlar o sistema de proteção de direitos de autor, traduzir, adaptar, modificar, desmontar ou caso contrário alterar o conteúdo, ou o software, ou qualquer tecnologia projetada para obrigar a observação das 'Limitações de Uso'. Você concorda e garante que não tentará modificar o software ou as regras de uso por qualquer razão, ou outras atividades que visem remover ou elidir os direitos dos autores das músicas, sendo responsável pelos danos que vier a causar ao iMusica e a terceiros." Disponível em: <http://www.imusica.com.br/TermosDeUso.aspx). Acesso em: 19 ago. 2007).

292 Existe ainda, no contrato, a cláusula décima primeira, a qual contém disposições que buscam isentar a iMusica de responsabilidades em geral, que contrariam o previsto na normativa de defesa do consumidor. 
se impõe ao usuário a obrigação de verificar as diferentes regras de licenciamento adotadas pelas gravadoras.

Se o usuário, após ler as condições contratuais (o que, na prática, raramente ocorre) optar por aceitá-las, apto está a comprar as músicas e as respectivas licenças de uso e, para executá-las, deverá ter instalado em seu computador o específico software Windows Media Player, da Microsoft, que contém o mecanismo de DRM apto a reconhecer e gerir as regras impostas pelos titulares de direitos autorais.

Uma vez ultrapassadas as etapas, o usuário poderá escutar as músicas adquiridas em seu computador, desde que mediante a observância dos termos de licença.

2.6.3.1.1 O caso dos aparelhos leitores portáteis de música digital e os sítios brasileiros de distribuição de música

Muitos dos usuários de música digital se utilizam dos chamados aparelhos Digital Audio Players, que podem ser considerados a evolução do rádio de bolso ou mesmo do antigo Walkman $^{293}$, dispositivo portátil para se escutar sons de fitas-cassete. São diversos os formatos sob os quais tais aparelhos funcionam, sendo que a maioria utiliza como padrão o MP3.

Os que despertam maior desejo nos consumidores, pelo design e inovação, são os produtos oferecidos pela Apple, denominados iPods, os quais, além de possibilitar a execução de músicas em MP3 também o fazem pelo formato AAC (Advanced Audio Coding), que utiliza menor volume de dados, possibilitando o acúmulo de maior número de faixas musicais num mesmo aparelho.

Ocorre que os principais serviços nacionais oferecem músicas digitais on-line incompatíveis com o iPod, tendo em vista que o formato que vendem é o WMA (Windows Media Audio). Mas tais sítios, em violação às rígidas regras que impõem aos usuários, ensinam como burlar o DRM que acompanha as músicas que vendem.

293 Walkman é marca registrada da Sony e hoje, ao invés dos leitores de fitas-cassete, serve para designar a linha de digital audio players da mesma empresa. 
Segundo o iMúsica, no ícone "dúvidas freqüentes" da "ajuda":

Eu posso ouvir minhas músicas no meu iPod? Não é possível transferir suas músicas diretamente para o seu iPod. Para disponibilizá-las em seu aparelho, você deverá gravar um $\mathrm{CD}$ de Áudio, a partir do Windows Media Player, e converter este CD pelo iTunes. ${ }^{294}$

O aviso do serviço "Sonora", do portal Terra, é ainda mais direto:

Posso gravar as músicas que fiz download no iPod? O iPod funciona com uma tecnologia proprietária da Apple o que impede os arquivos do Sonora sejam transferidos para ele. Para contornar isso e poder passar as músicas que você comprou no Sonora para o iPod ou outro player portátil que não trabalhe com a tecnologia DRM versão 9 ou superior da Microsoft, você deve gravar um CD com as músicas desejadas e então depois transferi-las para o(s) seu(s) aparelhos. ${ }^{295}$ [grifo nosso]

Tais ensinamentos dos serviços brasileiros de músicas de como burlar os dispositivos técnicos e as informações sobre a gestão de direitos se revelam absolutamente contraditórios com as severas obrigações unilateralmente impostas aos usuários nos termos de uso dos sítios (inclusive e principalmente de observância a tais mecanismos) e nas licenças das músicas fazem frente à normativa autoral:

Art. 107. Independentemente da perda dos equipamentos utilizados, responderá por perdas e danos, nunca inferiores ao valor que resultaria da aplicação do disposto no art. 103 e seu parágrafo único ${ }^{296}$, quem:

I - alterar, suprimir, modificar ou inutilizar, de qualquer maneira, dispositivos técnicos introduzidos nos exemplares das obras e produções protegidas para evitar ou restringir sua cópia;

II - alterar, suprimir ou inutilizar, de qualquer maneira, os sinais codificados destinados a restringir a comunicação ao público de obras, produções ou emissões protegidas ou a evitar a sua cópia;

III - suprimir ou alterar, sem autorização, qualquer informação sobre a gestão de direitos;

294 Disponível em: <http://www.imusica.com.br/Ajuda.aspx?Id=52>. Acesso em: 19 ago. 2007. No mesmo sentido, o portal UOL Megastore, que comercializa músicas digitais: "5.4. No iPod Se você possui um iPod, você também pode ouvir as músicas compradas no UOL Megastore em seu aparelho. Para isso, escolha as músicas que você deseja ouvir e grave-as em um CD de áudio. Depois, utilize o iTunes para converter as músicas gravadas em um formato compatível com o iPod e colocá-las em seu aparelho." (Disponível em: <http://stcmegastore.uol.com.br/ajuda/ajuda-84.jhtm>. Acesso em: 19 ago. 2007).

295 Disponível em: <http://sonora.terra.com.br/help/ajuda_comoouvir.htm>. Acesso em: 19 ago. 2007.

296 LDA: "Art. 103. Quem editar obra literária, artística ou científica, sem autorização do titular, perderá para este os exemplares que se apreenderem e pagar-lhe-á o preço dos que tiver vendido.

Parágrafo único. Não se conhecendo o número de exemplares que constituem a edição fraudulenta, pagará o transgressor o valor de três mil exemplares, além dos apreendidos". 
IV - distribuir, importar para distribuição, emitir, comunicar ou puser à disposição do público, sem autorização, obras, interpretações ou execuções, exemplares de interpretações fixadas em fonogramas e emissões, sabendo que a informação sobre a gestão de direitos, sinais codificados e dispositivos técnicos foram suprimidos ou alterados sem autorização.

Com efeito, é de causar espécie verificar que justamente os serviços que vendem música "legalizada", fato pelo qual jactam-se em propagandas e nas principais páginas de seus sítios, ensinam e estimulam seus usuários a burlar os mecanismos de gestão de direitos inseridos nos arquivos eletrônicos que oferecem. Por que, então, não oferecem direto as músicas sem a proteção de dispositivos tecnológicos?

Tal paradoxal situação serve para demonstrar a oportunidade do tema em estudo, numa fase em que todos os sujeitos partícipes do mercado de música digital - e não somente os usuários, como os titulares de direitos autorais tentam fazer crer - ainda atuam sem a compreensão adequada perante os desafios introduzidos pela tecnologia digital.

No capítulo terceiro será objeto de análise o acima-mencionado art. 107 da lei autoral, que sanciona a isolada prática da burla de mecanismos tecnológicos, sem que haja a necessidade da efetiva infração aos direitos autorais.

\subsubsection{Os sítios estrangeiros de distribuição de músicas}

Foi a Sony Music Entertainment a primeira representante das majors a oferecer suas músicas on-line, através do serviço The Store, em 2000, entretanto cobrando o elevado preço de U\$ 3,50 (três dólares e cinqüenta centavos) por faixa e, na verdade, os usuários não adquiriam a música, mas apenas as escutavam por determinado período de tempo, como numa locação, já que a licença de uso expirava.

Logo após, a Sony uniu-se à Universal Music Group e lançou o serviço PressPlay, que consistia na subscrição, pelos usuários, ao acesso à musica on-line de artistas de seus acervos. Do mesmo modo, as demais majors (BMG, EMI, Warner Music Group), junto com algumas gravadoras independentes, lançaram o serviço MusicNet.

Entretanto, o preço por música era alto e o modelo de licenciamento era complexo, assim com era oferecido número de faixas em quantidade insuficiente a agradar aos consumidores, os quais já tinham à disposição os sítios e serviços ilegais, de modo que tais iniciativas fracassaram.

Nesse ínterim, os demais sítios internacionais que disponibilizavam músicas de forma "legal" ofereciam os catálogos das gravadoras independentes na tentativa de manter- 
se no mercado e, com isso, contribuíram para que o mercado musical se ampliasse cada vez mais.

Em 28 abril de 2003 a Apple lançou seu serviço de músicas on-line, o iTunes Store, oferecendo músicas dos catálogos das cinco principais gravadoras: BMG, EMI, Warner Music Group, Universal Music Group e Sony Music Entertainment, justamente aquelas que fracassaram nas suas tentativas anteriores no meio virtual.

Por U\$ 0,99 (noventa e nove centavos de dólar estadunidense) o consumidor pode transferir ao seu computador um arquivo digital contendo a música de sua escolha ${ }^{297}$, ou o álbum completo, no formato de compressão $\mathrm{AAC}^{298}$, desenvolvido em conjunto pelo Fraunhofer-Institut für Integrierte Schaltungen IIS ${ }^{299}$, Sony, Nokia, Dolby e AT\&T e apresentado como a evolução do MP3.

O iTunes Store oferece mais de 5 milhões de faixas musicais ${ }^{300}$ para aquisição on-line e, até 31 de julho de 2007 chegou à marca de 3 bilhões de músicas vendidas ${ }^{301}$. No início, o serviço era apenas oferecido nos Estados Unidos, sendo que a partir de junho de 2004 foi lançado no Reino Unido, França e Alemanha. Atualmente somente usuários residentes nos Estados Unidos, Canadá, alguns países do continente europeu, Austrália e Japão podem adquirir músicas por esse sítio $^{302}$, o que por conseqüência exclui os usuários brasileiros.

297 No que se convencionou chamar de "serviço à la carte" ou "à la carte services", cf. GartnerG2; THE BERKMAN CENTER FOR INTERNET \& SOCIETY AT HARVARD LAW SCHOOL. Copyright and Digital Media in a Post-Napster World. Version 2. Cambridge: Harvard Law School, jan. 2005. p.10.

298 "Advanced Audio Coding (AAC), também conhecido como MPEG-2 Part 7 ou MPEG-4 Part 3, é um formato de áudio, que recorre a compressão com perda de dados. Foi popularizado pela Apple Computer através de seus produtos iPod e iTunes Music Store. O AAC foi projetado como um codec de desempenho melhor em relação ao MP3, sendo promovido como seu sucessor para codificação de áudio em taxas de bits médias a altas." (WIKIPÉDIA. Desenvolvido pela Wikimedia Foundation. Apresenta conteúdo enciclopédico. Disponível em: <http://pt.wikipedia.org/w/index.php?title=Advanced_Audio_Coding\&oldid=7045825>. Acesso em: 9 ago. 2007).

299 Disponível em: <http://www.iis.fraunhofer.de/EN/bf/amm/projects/mpeg/index.jsp>. Acesso em: 9 ago. 2007.

300 Além de 100.000 podcasts, 27.000 audiobooks, 350 programas de televisão, além de filmes e jogos para iPods. Dados de agosto de 2007 (Disponível em: <http://www.apple.com/itunes/store/>. Acesso em: 9 ago. 2007).

301 Cf. <http://g1.globo.com/Noticias/Tecnologia/0,,MUL80621-6174,00.html>. Acesso em: 9 ago. 2007.

302 Cf. lista disponível em: <http://www.apple.com/legal/itunes/ww/>. Acesso em: 9 ago. 2007. 
O modelo de negócios do iTunes Store é uma evolução em relação à aquisição do CD completo, mas pode ser considerado limitado na medida em que somente oferece a cobrança de valor fixo por música, justamente o fator que lhe era diferencial positivo no lançamento do serviço ${ }^{303}$, em contraposição a outros que exigiam pagamento de subscrição mensal para se ter acesso a determinado número de músicas, além do pagamento individual por faixa musical ${ }^{304}$.

O fundador, presidente e acionista da Apple, Steve Jobs, em artigo publicado em 6 de fevereiro de 2007 no sítio da empresa, dá sinais de que continua a praticar unicamente tal modelo de negócios por ser refém da situação posta, ao afirmar que

uma vez que a Apple não é proprietária nem controla qualquer música por si mesma, deve licenciar de terceiros os direitos de distribuí-las, principalmente as gravadoras 'big four': Universal, Sony BMG, Warner e EMI. Essas quatro companhias controlam a distribuição de $70 \%$ da música mundial. ${ }^{305}$

A entrada do iTunes Store no mercado de distribuição de músicas foi paradigmática também por representar importante meio de acesso das gravadoras independentes ao

303 "Apple's iTMS was the first service with content from all five major labels to sell songs à la carte with no subscription fees. The Store's pricing seems both revolutionary and obvious - the former because the prices are significantly lower than previous services' (including brick-and-mortar CD stores), and the latter because they come closer to projected price points." (Gartner|G2 \& BERKMAN CENTER. iTunes: How Copyright, Contract, and Technology Shape the Business of Digital Media - A Case Study. Cambridge: Harvard Law School, 15 jun. 2004. p.9).

304 Atualmente, alguns de seus concorrentes oferecem ambas as opções, de subscrição mensal ou escolha individual da música.

305 Tradução livre de "since Apple does not own or control any music itself, it must license the rights to distribute music from others, primarily the "big four" music companies: Universal, Sony BMG, Warner and EMI. These four companies control the distribution of over $70 \%$ of the world's music" (JOBS, Steve. Thoughts on music. Publicado em 6 fev. 2007. Disponível em: <http://www.apple.com/hotnews/thoughtsonmusic/>. Acesso em: 9 ago. 2007). N'algo semelhante ao que ocorre no Brasil, conforme quadro em reportagem jornalística sobre venda de música digital pela internet: "Por que a música digital custa tão caro no Brasil? As lojas brasileiras iMusica, Terra Sonora e UOL Megastore vendem a maioria das faixas a preços que vão de R\$ 1,89 a R\$ 2,49 cada uma. Procuradas pelo Link, as três têm um discurso parecido. Os executivos dizem que gostariam de cobrar preços menores, mas que os valores foram definidos em contrato pela gravadoras. 'O preço é estipulado por elas', diz o gerente do UOL Megastore, Jan Fjeld. 'Não custa R\$ 2,49 porque eu acho certo.' Segundo ele, às vezes dá para baixar o valor e cita o novo disco da banda Pato Fu, Daqui pro Futuro, que custa R\$ 9,90. Diz que isso foi possível porque se fechou um acordo com uma gravadora independente, processo que tenta repetir com as gigantes do ramo. 'Estamos negociando para baixar os preços e vender sem DRM.' Duas gravadoras já reduziram os valores. A Warner definiu que cada faixa sai por R\$1,89 e a Sony-BMG, por R\$1,99. 'Há também os impostos e o preço das editoras (que cuidam dos direitos autorais)', disse o gerente de produto do Terra Sonora, Beni Goldenberg. Segundo o diretor-executivo do iMusica, Felipe Llerena, existe uma política mundial de preços e todos acabam tendo de segui-la". (MORAES e SILVA, Maurício. Porque a música digital custa tão caro no Brasil?. O Estado de S. Paulo, São Paulo, 01 out. 2007, Caderno Link, p.L3). 
mercado, já que mais de 1000 selos de tal natureza passaram a disponibilizar músicas de seus catálogos por meio desse serviço ${ }^{306}$. O ineditismo se dá não propriamente pela oferta de selos independentes na internet mas por conta do fato de que dificilmente se veria, nas grandes lojas "reais" de CDs, um disco das chamadas indies lado de um disco das majors.

Conforme mencionado alhures, os residentes no Brasil não podem adquirir músicas do iTunes Store, daí porque não se fará, no presente estudo, uma análise mais aprofundada da problemática jurídica correspondente, muito embora se possa assinalar que existem relevantes questões, mormente aquelas oriundas da tensão entre aspectos contratuais impostos pelas gravadoras ${ }^{307}$ ou pelos fornecedores dos serviços que ampliam abusivamente a proteção garantida pelos direitos autorais, ferindo direitos do consumidor e mesmo de personalidade, a exemplo da privacidade ${ }^{308}$.

Além do bem-sucedido serviço da Apple verifica-se, em termos internacionais, a existência de outros que distribuem músicas para serem transferidas on-line, no mesmo modelo do iTunes Store, a exemplo do Wal-Mart309 e do "eMusic"310 e, recentemente, o ingresso da gigante on-line Amazon ${ }^{311}$.

306 Dados de 2005 cf. ensaio acadêmico de Urs Gasser and Gabriela Ruiz Begue no "The Berkman Center for Internet and Society at Harvard Law School" (GASSER, Urs; BEGUE, Gabriela Ruiz. iTunes: Some Observations After 500 Million Downloaded Songs. Cambridge: Harvard Law School, ago. 2005. p.2).

307 É o ponto crucial do já mencionado artigo de Steve Jobs, conforme nota de rodapé acima. Entretanto, sua empresa, a Apple, é acusada de práticas anticoncorrenciais ao impedir que outros sítios que oferecem música e fabricantes de digital audio players se utilizem do formato .AAC, utilizado como padrão tanto no iTunes quanto nos iPods.

308 Para estudos aprofundados sobre o tema, sugere-se a leitura de dois trabalhos acadêmicos publicados pela Faculdade de Direito da Universidade de Harvard (Gartner|G2 \& BERKMAN CENTER, iTunes... e GASSER, BEGUE, iTunes...

309 Disponível em: <http://musicdownloads.walmart.com/catalog/servlet/MainServlet>. Acesso em: 9 ago. 2007.

310 Disponível em: <http://www.emusic.com/>. Acesso em: 9 ago. 2007.

311 Tal ingresso foi amplamente divulgado pela mídia, já que corresponde à possibilidade de efetiva concorrência ao iTunes. O jornalista Maurício Moraes e Silva destaca que o preço praticado é vantajoso em relação aos dos sítios nacionais e mesmo aos do serviço da Apple, sendo que as músicas não possuem travas tecnológicas (DRMs). Como desvantagem aduz a restrição de que usuários de fora dos Estados Unidos façam seus downloads. Consta da reportagem: "Mas, de tudo isso, o que 'pega' mesmo é o preço mais barato. O problema é que, em tese, a Amazon não pode vender música para clientes tupiniquins. Os termos de uso do serviço dizem claramente que existem restrições territoriais: o conteúdo está disponível apenas a moradores dos Estados Unidos. O mesmo ocorre com a loja iTunes, que não aceita cartões de crédito internacionais com endereço brasileiro. Só que, ao contrário do serviço da Apple, dá para adquirir faixas na Amazon com o 'jeitinho brasileiro'. Após selecionar o que deseja comprar, o cliente fornece os dados do cartão de crédito internacional e, então, a Amazon pedirá um endereço norte-americano. $\mathrm{Na}$ 
Ainda, em 2004 a Microsoft lançou o MSN music para confrontar a Apple, cujo modelo de negócios foi similar mas, na prática, ao contrário, se revelou um grande fracasso, dando a impressão de que a própria Microsoft não deu a devida importância ao que oferecia. Em novembro de 2006 tal serviço de comercialização de músicas foi extinto, com o lançamento do tocador de música digital portátil "Zune" e do correspondente serviço de oferta de músicas denominado "Zune Marketplace" que, por sua vez, pratica tanto a venda de músicas "à la carte", modelo do iTunes, quanto por meio de subscrição mensal.

No sistema "à la carte" oferecido pelo "Zune" o usuário escolhe a música de sua preferência e pode transferi-la para o meio físico CD e, pelos termos do contrato de licença, elas não perdem a validade. Já no sistema de subscrição, havendo o pagamento da mensalidade, o usuário tem o direito de escutar as músicas, sendo certo que elas "expirarão" caso não haja o pagamento, além do que, nessa opção, o consumidor não pode transferi-la para CD. Tal serviço, entretanto, atualmente só é oferecido aos residentes nos Estados Unidos da América e, pela novidade que constitui, não se sabe ao certo quanto ao sucesso que terá.

A justificativa dada pelos serviços internacionais para que não funcionem no Brasil é de ordem contratual. Alegam que os titulares de direitos autorais somente licenciam seus fonogramas para determinadas regiões onde já "exista a compreensão" da proteção normativa conferida, o que não se justifica, em vista da harmonização já havida até o momento em decorrência do direito dos tratados, especialmente a edição dos tratados OMPI de Internet.

semana passada, bastava preencher os campos com o mesmo endereço do Brasil, com exceção de CEP, cidade e Estado. Era só colocar, por exemplo, '90210' (o CEP do seriado Barrados no Baile), 'Los Angeles' e 'CA' (de Califórnia) e pressionar o botão 'Continue' para concluir o processo. Aí, é necessário instalar um programinha para fazer o download. Claro que quem fizer isso vai pagar bem barato, mas pode sofrer punições indigestas - afinal, como costuma dizer o ex-árbitro e comentarista Arnaldo Cezar Coelho, 'a regra é clara'. Se as condições forem desobedecidas, e a Amazon decidir controlar, o cliente deverá parar de usar o conteúdo digital já adquirido e poderá ter o acesso ao serviço bloqueado. Permite-se inclusive que os donos dos direitos autorais invoquem esse regulamento contra o usuário infrator". Com efeito, uma vez que o detentor dos direitos autorais licenciou a música somente para determinado território, o usuário que tenta burlar os termos da licença incorre na prática do que popularmente se chama de "jogar dinheiro fora", já que é tanto infrator quanto aquele que baixa conteúdo por uma rede peer-to-peer ou ainda adquire um CD pirata. Conforme será visto no capítulo terceiro, essa é uma decorrência da contratualização dos direitos autorais (MORAES e SILVA, Maurício. Amazon começa a vender música digital pela internet. O Estado de S. Paulo, São Paulo, 01 out. 2007, Caderno Link, p.L3). 
De todo modo, demonstra-se de grande valia acompanhar os modelos de negócios instalados nos Estados Unidos, que sempre criou parâmetros para o funcionamento de indústria fonográfica.

Outrossim, parece claro que no caso da distribuição on-line de obras musicais se faz necessária a concordância dos titulares de direitos autorais para tal forma de utilização, o que se dá mediante autorização por meio de contratos de licenciamento.

\title{
2.6.4 As "Rádios" On-Line
}

As chamadas "rádios" on-line constituem uma das principais inovações trazidas pela internet. É a definição de Webcasting, baseada em Steve Gordon ${ }^{312}$ :

\begin{abstract}
algumas vezes referido como 'internet radio', geralmente significa o streaming não-interativo de áudio na internet. O conteúdo pode ser originário de várias fontes, inclusive conversação ao vivo ou pré-gravada, apresentação musical ao vivo a eventos esportivos, bem como música pré-gravada. Existem basicamente dois tipos de webcasts: serviços somente baseados na internet e estações de rádio que simultaneamente transmitem por radiodifusão e fazem o streaming da mesma transmissão em forma digital pela internet.
\end{abstract}

Constata-se, entretanto, imprecisão terminológica jurídica na denominação das "rádios on-line", já que não praticam a radiodifusão nem tampouco são objeto de regulação estatal, por não utilizarem o bem público do espectro de radiofreqüências ${ }^{313}$. É fato, outrossim, que tal expressão já é largamente utilizada.

312 GORDON, The future of music..., p.26.

313 "O espectro de radiofreqüências foi proclamado um 'bem público', pela Lei Geral das Telecomunicações - LGT (Lei n. ${ }^{\circ}$ 9.472, de 16 de julho de 1997), de uso limitado e oneroso, (...), salvo nos casos previstos na própria lei." (LOSSO, Ezequias. Atividade empresarial de telefonia de radiofreqüência e inclusão social. 2007. Dissertação (Mestrado em Direito) - Faculdades Integradas Curitiba, Curitiba, 2007. p.20). No mesmo sentido, Denis Borges Barbosa e Nelida Jabik Jessen: "Não se imagine que uma comparação de um site com uma estação de rádio levaria a questão para fora do direito autoral, colocando-o no Direitos das comunicações. Em relação à radio fusão, inclusive, após extenso estudo da legislação específica de telecomunicações, verificou-se inexistir dispositivos referentes ao serviço de rádio na Internet. Em momento algum, a lei geral de telecomunicações (Lei 9.472/97) ou o Código Brasileiro de Telecomunicações (Lei 4.117/62) dispõem a respeito do serviço de rádio fornecido através de sites na Internet. Aliás, se dispusesse, isso faria tal serviço sujeito à concessão e ao pleito público." (BARBOSA, Denis Borges; JESSEN, Nelida Jabik. O uso livre de música encontrada na internet. 2000. Disponível em: <http://denisbarbosa.addr.com/116.DOC>. Acesso em: 27 out. 2007). 
Com efeito, ao invés de tão-somente receber as músicas (acompanhadas de comerciais) selecionadas pelos operadores de radiodifusão (muitas das vezes com a escolha contaminada pelo "jabá"314), a internet possibilitou o desenvolvimento de uma tecnologia interativa, com o que o usuário passou a ter postura ativa mediante o exercício de uma série de prerrogativas para definir o que pretende escutar.

Da mesma maneira, os artistas não vinculados a gravadoras podem criar suas próprias rádios ou ainda sugerir que os operadores de rádios virtuais ofereçam suas músicas à audiência de seu público. As possibilidades de exposição de novos artistas são inúmeras ${ }^{315}$.

Já são milhões de rádios disponíveis pela internet, criadas tanto a partir de sítios que disponibilizam as ferramentas - e, em alguns casos, as próprias músicas - para que qualquer um possa fundar sua rádio on-line. São algumas dos principais serviços que oferecem rádios on-line: Last.fm, Pandora, Rhapsody, SomaFM, Live365 e MTV, cada qual com seu próprio modelo de negócios.

É importante notar que, ao contrário do sistema do direito de autor continental, no qual os direitos de execução pública sempre foram coletados e distribuídos aos respectivos titulares (no Brasil por meio do ECAD - Escritório Central de Arrecadação e Distribuição), pelas diversas formas de utilização (inclusive e principalmente radiodifusão), nos Estados Unidos somente a partir de 1995, com o The Digital Performance in Sound Recordings Act é que foi introduzida a possibilidade de cobrança em relação à utilização no meio digital ${ }^{316}$.

314 Tema sobre o qual já foi tratado no capítulo primeiro.

315 "Internet radio is a terrific way for new music to get exposed and associated with particular genres, related artists and tastemakers. Music programmers at these Internet radio stations serve up an increasingly wide variety of new music from indie labels and individual artists, as well as by all of the majors. This source of content programming is a great vein for music marketers to tap and can provide exposure for their artists in an environment that supports creative discovery and diverse tastes". (KUSEK, LEONHARD, The future of music..., p.62).

316 "Prior to 1995, Sound Recording Copyright Owners (SRCOs) in the United States did not have a performance right. This meant that, unlike their counterparts in most of Europe and other nations around the world, recording companies and artists were not entitled to receive payment for the public performance of their works. Users of music, the digital music service providers, freely performed these works at will, without a dime being paid to the rightful owners of those recordings or the featured artists who performed the songs - the recordings which created the backbone of their business." (Tópico Background em: <http://www.soundexchange.com>. Acesso em: 27 out. 2007). 
Mais uma vez a evolução tecnológica fez com que as normas autorais mudassem. Devido ao caráter transnacional não somente da internet, mas também das emissões de rádio por satélite, desvelou-se uma situação desproporcional entre as gravadoras e intérpretes dos Estados Unidos em relação aos congêneres dos países que adotam o sistema de direito de autor continental, já que aqueles não eram remunerados por execuções havidas no ambiente digital, enquanto esses recebiam suas contraprestações.

Logo após, em 1998, sobreveio o Digital Millennium Copyright Act, estatuto americano sobre direitos autorais na internet ${ }^{317}$, o qual consolidou a obrigatoriedade de pagamento pelas execuções públicas e apresentações (performances), bem como dispôs sobre o pagamento da utilização nos meios digitais, com exceção, entretanto, da cobrança de valores das emissoras de rádio "tradicionais", ou seja, aquelas que detêm a autorização de funcionamento concedida pela agência reguladora competente (no caso estadunidense a FCC - Federal Communications Commission), que podem efetuar a transmissão de seus conteúdos pela internet sem qualquer pagamento.

A lei atribuiu ao The U.S. Copyright Office (departamento oficial de direitos autorais), vinculado ao Poder Legislativo estadunidense, a missão de organizar a cobrança e o repasse dos direitos de execução pública e utilização dos fonogramas. Tal órgão, por sua vez, designou a associação sem fins lucrativos SoundExchange como a entidade administrativa para coletar os valores correspondentes, com base no determinado pelo Copyright Royalty Board, conselho estabelecido em 2004 pelo Congresso estadunidense ${ }^{318}$. Foi a extensão do mecanismo do licenciamento compulsório ao meio digital ${ }^{319}$.

317 E, por que não dizer, estatuto mundial, em vista de os principais sítios e serviços disponíveis nesse ambiente digital serem oriundos dos Estados Unidos.

318 Artigos jornalísticos informam que em março de 2007 o Copyright Royalty Board ratificou aumento progressivo das taxas cobradas das rádios on-line, o que gerou protestos por parte dos empreendedores nesse segmento, que denunciam a inviabilização do modelo de negócios e, principalmente, a impossibilidade da sobrevivência das rádios de menor porte. Vide LEVINE, Robert. EUA aumentam taxa de música online. Originalmente publicado no The New York Times. Disponível em: $<$ http://www.link.estadao.com.br/index.cfm?id_conteudo=10541>. Acesso em: 27 de out. 2007 e PINHEIRO, Daniel. No Brasil, taxa sobre direitos autorais para rádios online. Disponível em: <http://tecnologia.uol.com.br/ultnot/2007/04/19/ult4213u77.jhtm>. Acesso em: 27 de out. 2007.

319 Tema sobre o qual será tratado no capítulo terceiro. 
De acordo com a lei brasileira o funcionamento dessas rádios on-line caracteriza: i) uma transmissão ${ }^{320}$ de sons digitalizados de uma obra musical; ii) uma comunicação ao público $^{321}$; e iii) uma reprodução ${ }^{322}$, na medida em que por meio do streaming há armazenamento temporário na máquina do usuário.

O funcionamento dessas rádios on-line não somente se mostra compatível com os direitos autorais como aqueles que as operam lhes devem observância, o que nem sempre ocorre, especialmente quando o sujeito não utiliza um dos serviços disponíveis na internet, que tomam para si a responsabilidade pelo recolhimento das retribuições autorais.

\subsubsection{A Transmissão de Arquivos Digitais pelas Redes Ponto-a-Ponto}

Fator determinante para que a indústria fonográfica despertasse para os novos tempos foi a popularização da utilização da tecnologia peer-to-peer (P2P ou ponto-a-ponto em vernáculo) para a transferência das músicas, já devidamente comprimidas principalmente pela da tecnologia MP3 e outras disponíveis na rede, que foi ainda facilitada pela conexão banda-larga à internet ${ }^{323}$.

A tecnologia P2P consiste, em termos sucintos, numa estrutura "onde cada cliente conectado pode comunicar-se diretamente com outro cliente sem haver necessidade direta de um servidor, pois o cliente também faz este papel"324.

320 LDA, art. 5. ${ }^{\circ}$, II.

321 LDA, art. 5. ${ }^{\circ}, \mathrm{V}$.

322 LDA, art. 5. ', VI. Observe-se, entretanto, o caráter sui generis da reprodução temporária para fins de conformação com o meio eletrônico: "Art. 30. No exercício do direito de reprodução, o titular dos direitos autorais poderá colocar à disposição do público a obra, na forma, local e pelo tempo que desejar, a título oneroso ou gratuito.

$\S 1$. $^{\circ} \mathrm{O}$ direito de exclusividade de reprodução não será aplicável quando ela for temporária e apenas tiver o propósito de tornar a obra, fonograma ou interpretação perceptível em meio eletrônico ou quando for de natureza transitória e incidental, desde que ocorra no curso do uso devidamente autorizado da obra, pelo titular".

323 Note-se que tal mistura de ingredientes: P2P + MP3 + conexão banda larga originou uma fórmula muito querida aos usuários de músicas e, a partir de então, tem sido um sucesso.

324 VOSS JUNIOR, José; PÉRICAS, Francisco Adell. Compartilhamento de informações entre computadores através da tecnologia Peer-to-Peer (P2P) usando a plataforma JXTA. Artigo apresentado no XIII Seminário de Computação da FURB. Disponível em: <http://www.inf.furb.br/seminco/2004/artigos/102vf.pdf>. Acesso em: $10 \mathrm{dez} .2007$. 
Tal estrutura possibilita o compartilhamento de dados de forma muito simples, de modo que o usuário comum pode oferecer aos outros sua coleção musical digital, quando está conectado à internet, ao mesmo tempo em que acessa outros computadores para baixar as músicas que lhe interessam ${ }^{325}$.

$\mathrm{O}$ roteiro a ser cumprido pelo usuário que pretende se utilizar da tecnologia $\mathrm{P} 2 \mathrm{P}$ para obter músicas pela internet se resume: i) na definição, download e instalação do aplicativo que será utilizado, dentre os vários disponíveis (eMule, Kazaa, LimeWire, Shareaza, Imesh, Morpheus, Ares, SoulSeek etc.); ii) uma vez instalado o software, sua execução pode ser feita quando o usuário desejar, ocasião em que se tem acesso à listagem do conteúdo de arquivos disponíveis em pastas de compartilhamento de outros computadores pessoais simultaneamente conectados à internet, do mesmo modo que disponibiliza os arquivos armazenados na pasta de compartilhamento de seu computador pessoal, oferecendo-os aos demais usuários no ato que se denomina upload; iii) o usuário escolhe a(s) música(s) que pretende baixar, por meio de mecanismo de pesquisa e clica no correspondente botão para dar início ao download do(s) arquivo(s) e recebê-lo(s) em seu computador pessoal. A velocidade de recepção dos arquivos é diretamente proporcional à velocidade de sua conexão e do(s) outro(s) computador(es) à internet.

Podem ser localizadas desde gravações amadoras das chamadas "bandas de fundo de garagem" que voluntariamente as disponibilizam, quanto cópias de músicas de sucesso ou de álbuns inteiros lançados pela indústria fonográfica, as quais não autorizam sua disseminação por outra forma que não pelos canais oficiais (aquisição de CDs em lojas especializadas ou, na internet, por serviços autorizados a tal). É interessante notar que não é difícil localizar exemplares de obras musicais raras, a exemplo das apresentações desconhecidas de intérpretes famosos, sobre as quais não se tomaria conhecimento de outra forma.

É, assim, improvável que o usuário que trava contato com tal tecnologia volte a adquirir músicas tão-somente pela maneira tradicional - a aquisição de CDs. É o que Stan J.

325 Muito embora neste estudo se faça a análise da tecnologia P2P como instrumento de disseminação de músicas, ela possibilita múltiplas aplicações. É o que informam os franceses Françoise Benhamou e Joëlle Farchy: "Le P2P est utilisé pour de multiples applications: jouer en ligne, organiser des visioconferénces ou de la messagerie instantanée, échanger des connaissances, des photos, diffuser des contenus interactifs, faciliter lê stockage massif des donées, partager des documents ou des informations, mutualiser les puissances de calcul. Les applications comme la téléphonie sur Internet ou la téléphonie móbile de troisème génération (dont la vitesse accrue de transmission de donnés ouvre la porte à des services nouveaux) reposent, elles aussi, sur la technologie P2P". (BENHAMOU e FARCHY, Droit d'auteur..., p.59). 
Liebowitz, sob o enfoque econômico, denomina de substitution effect ${ }^{326}$ (ou "efeito de substituição"), que ocorre quando o consumidor deixa de adquirir cópia original da música em virtude de ter acesso a meio alternativo para tal. $\mathrm{O}$ mesmo autor apresenta o contraponto de tal efeito, o exposure effect (ou "efeito de exposição"), que consiste na compra efetuada por alguém que teve acesso ao produto (no caso, a música) por outro meio alternativo e, baseado nisso, decidiu adquirir cópia original ${ }^{327}$.

Deborah de Angelis, ao analisar o que chama de "fenômeno" do P2P, afirma que "são múltiplas as razões que podem concorrer para explicar a origem, a difusão e o sucesso de tal fenômeno: 1) a desconfiança demonstrada pela indústria musical com relação às novas tecnologias; 2) o preço elevado dos suportes musicais; 3) a escassa diversificação da oferta com referência tanto aos suportes quanto aos produtos; 4) a falta da percepção do ilícito pelo público"328.

A autora italiana bem resume a questão, de modo que suas pontuações são tomadas como base de breve análise. Quanto ao primeiro aspecto, da desconfiança demonstrada pela indústria musical com relação às novas tecnologias, se essa tivesse se adiantado e realizado investimentos estratégicos, provavelmente teria modificado por si mesma e de forma controlada os hábitos de seu público consumidor.

O vácuo causado pela inação dos titulares de direitos autorais foi preenchido por outras formas de exploração de obras musicais e fonogramas, não necessariamente legais.

326 "The substitution effect, as its name implies, occurs when someone forgoes the purchase of the original (record) because they have access to an alternative (the copy or in this case, radio play). The substitution effect maps nicely into the consumption motive of radio listening. If a copy or alternative is a replacement for the purchase of an original, demand for the original falls. This cannot help but harm the seller of originals." (LIEBOWITZ, The Elusive Symbiosis..., p.6).

327 Muito embora o efeito de exposição seja contraponto ao efeito de substituição, ambos podem ser negativos ao produtor musical. Para o citado autor: "the exposure effect occurs when someone makes a purchase they would not have made except for the fact that they were able to sample the product in another venue (listening to a copy or on the radio). This maps nicely into the shopping motive. Note that the exposure effect doesn't necessarily have a positive impact on sales, and thus doesn't necessarily have an impact different than the substitution effect. Learning more about a product prior to purchase may allow consumers to derive greater utility from any single purchase. At any given price, however, they may purchase fewer units because they become more quickly satiated. Producers, therefore, may discover that their revenues fall when consumers can better sample the products" (LIEBOWITZ, The Elusive Symbiosis..., p.6-7).

328 Tradução livre de "sono molteplici le ragioni che possono concorrere a spiegare l'origine, la diffusione e il successo di tale fenomeno: 1) la diffidenza mostrata dall'industria musicale verso le nove tecnologie; 2) il prezzo elevato dei supporti musicali; 3) la scarsa diversificazione dell'oferta con riferimento sia ai supporti che ai prodotti; 4) la mancanza della percezione dell'illecito presso il pubblico" (De ANGELIS, La tutela giuridica..., p.188). 
A incapacidade de a indústria fonográfica prever e reagir, provavelmente causada pelo gigantismo das suas maiores representantes, impediu com que essas voltassem suas atenções para o novo meio da internet como uma oportunidade de novos negócios e satisfação de seus usuários, no qual poderiam ter efetuado investimentos em pesquisa e desenvolvimento e lançado, em primeira mão, inovadores produtos.

Outrossim, é relevante notar que tal postura de resistência da indústria fonográfica é recorrente, como bem constata a americana Cassandra Jacqueline Imfeld, em sua tese de doutorado "Repeated resistance to new technologies: a case study of the recording industry's tatics to protect copyrighted works in cyberspace between 1993 and 2003", defendida e aprovada na University of North Carolina:

Por mais de cem anos, as novas tecnologias têm desafiado a capacidade da indústria
fonográfica em controlar a reprodução e a distribuição de suas obras. Com a
introdução de cada inovação, a indústria fonográfica alega que a nova tecnologia
poderia conduzi-la à sua morte econômica. A indústria fonográfica tem
repetidamente interpretado as inovações como ameaças ao seu controle sobre
suas obras. Como resultado, a indústria fonográfica tem repetidamente resistido
às novas tecnologias e buscado proteger o status quo e seus modelos de negócios
existentes através do litígio e de legislações adicionais de direitos autorais.
Desde o final do século dezenove, com a introdução da pianola e das gravações
em fonógrafos, essa tensão entre novas tecnologias e a legislação autoral
estadunidense pode ser constatada. ${ }^{329}$

É de notar, entretanto, que a inação da indústria fonográfica acabou por se revelar benéfica ao público consumidor e ao segmento musical em geral, uma vez que resultou num modelo de negócios diferenciado e incentivou o ingresso de novos sujeitos no cenário musical: artistas, gravadoras independentes e empreendedores que passaram a pautar suas atividades nas possibilidades trazidas pelas novas tecnologias, que travam contato com seu público por maneiras diferentes daquelas tradicionais, baseadas num sistema de marketing utilizado há décadas e dominado pelas grandes gravadoras.

329 Tradução livre de "for more than a hundred years, new technologies have challenged the recording industry's ability to control the reproduction and distribution of its works. With the introduction of each innovation, the recording industry claimed the new technology would lead to its economic demise. The recording industry has repeatedly viewed innovations as threats to its control over its works. As a result, the recording industry has repeatedly resisted the new technologies and sought to protect the status quo and its existing business models through litigation and additional copyright legislation. Since the late nineteenth century with the introduction of piano rolls and phonorecords, this tension between new technologies and U.S. copyright law can be seen". (IMFELD, Cassandra Jacqueline. Repeated resistance to new technologies: a case study of the recording industry's tatics to protect copyrighted works in cyberspace between 1993 and 2003. 2004. Tese (Doutorado em Filosofia) - Departamento de Jornalismo e Comunicação de Massa - University of North Carolina, Chapel Hill, 2004). 
Em relação ao segundo ponto levantado por De Angelis, constata-se que realmente os preços dos suportes musicais se demonstram injustificáveis, e isso não apenas como ônus exclusivo dos brasileiros ${ }^{330}$, uma vez que sempre existiu similitude global na política de preços, até em vista da já mencionada administração centralizada das majors.

Percebe-se que a partir do momento em que deixou de pagar pelas músicas, em vista dos downloads gratuitos que passou a fazer, por meio do $\mathrm{P} 2 \mathrm{P}$, o consumidor se interessou por conhecer o funcionamento do mercado fonográfico, passou a questioná-lo e se deu conta da alta margem de lucro praticada, considerada abusiva.

Por outro lado, a indústria fonográfica sempre negou praticar preços elevados e creditou os valores praticados como decorrentes dos custos de operação das organizações empresariais que mantêm e dos diversos níveis da cadeia de distribuição, também com a geração de empregos, o pagamento de tributos e de retribuição aos compositores e artistas intérpretes e executantes, além dos elevados dispêndios para o combate à pirataria.

Cabe repisar que tal justificativa vem desde o momento em que a indústria fonográfica estava mais preocupada com a chamada pirataria física, consistente na reprodução comercial de CDs, mercado em que operam verdadeiros empresários da contrafação, que lucram altos valores mediante o investimento em aparelhos duplicadores de CDs e matéria-prima, e que contam com forte e ilegal rede de distribuição. Ou, mais além, desde que a fita-cassete foi lançada.

Realmente, é fato notório que no Brasil, tanto a carga tributária, quanto os ônus trabalhistas diretos e indiretos constituem um fator que causa impacto nos custos de qualquer produto e os piratas não arcam com qualquer desses encargos.

No entanto, os preços exorbitantes são praticados há muito tempo, antes mesmo da pirataria física de CDs, sendo que uma conta feita levando-se em consideração o custo total de produção de um álbum dividido pelo número de cópias que nos tempos áureos eram vendidas demonstra a extrema lucratividade que havia na atividade, não necessariamente por preenchimento dos quesitos eficiência e qualidade, mas pela já mencionada característica oligopolística do mercado fonográfico, com espécie de "tabelamento" de preços sem a adoção de um parâmetro razoável.

330 Informa a autora italiana Deborah De Angelis que "in effetti, il costo attuale di un compact disc si attesta intorno a 17-22 $€$, cifra che risulta spesso fuori della portata della maggior parte degli adolescenti e dei giovani adulti, da sempre i maggiori utilizzatori dei contenuti audio e video" (De ANGELIS, La tutela giuridica..., p.189). 
De qualquer forma, não é sensata a postura da indústria fonográfica em equiparar o usuário que compartilha as músicas de sua preferência com seus amigos com aqueles que obtêm lucro com tal iniciativa, conforme adiante será tratado.

O público, ainda, passou a perceber que aos seus artistas e compositores preferidos restavam somente ínfima parcela das receitas das vendas dos CDs, e que os respectivos resultados financeiros provinham de suas atuações em shows, cessão de direito de imagem para campanhas publicitárias de produtos e comércio em geral e retribuição autoral das execuções públicas ${ }^{331}$.

Na seqüência do resumo que a autora Deborah De Angelis fez para explicar o fenômeno do P2P, ela aponta como terceira razão "a escassa diversificação da oferta com referência tanto aos suportes quanto aos produtos". Com efeito, conforme já visto no capítulo anterior, a competitividade do mercado fonográfico era ficta, uma vez que as poucas corporações atuantes no ramo, de tempos em tempos, promoviam fusões e aquisições entre si, de modo que a elas não interessava a guerra franca. A partir disso, os lançamentos de novos artistas era, na maioria das vezes, incumbência das pequenas gravadoras, que tinham a função de "trampolim" para um contrato com alguma das majors, no caso de sucesso. Ou então, se o lançamento de alguma banda fosse feito diretamente por alguma das grandes gravadoras, invariavelmente o era após profunda pesquisa de marketing para se verificar qual a demanda do mercado, não necessariamente do que se desejava ouvir, mas do que seria certamente um sucesso. Então eram selecionados "a dedo" os integrantes das bandas musicais, mediante critérios que agradassem o público - mormente aqueles de aparência física -, os quais raramente incluíam a qualidade artística.

Quando verificada alguma linha de sucesso, lançavam grupos repetidores até que se esgotava tal nicho. Impunham-se, assim, determinados padrões que levavam a determinado tipo de consumo, sobretudo de fácil descarte.

O hábito era que os álbuns fossem lançados contendo geralmente apenas duas ou três músicas que se tornariam os sucessos, os chamados "hits" (normalmente aquelas inseridas em trilhas sonoras de novelas ou em comerciais e repetidamente exacutadas pelas rádios), sendo os usuários forçados a adquirir o álbum completo contendo de dez a quinze músicas.

331 Nesse item, aliás, em termos, já que também é fato notório a insatisfação da maioria dos compositores e artistas quanto aos critérios de distribuição de tais direitos. 
Isso foi modificado com o advento da internet, especialmente com as redes pontoa-ponto. O usuário pode escolher especificamente qual faixa musical pretende baixar e assim o faz, montando seu acervo da maneira que melhor entender.

Por outro lado, a vã tentativa em se manter o status quo no que diz respeito aos suportes tecnológicos, pretendendo que os CDs fossem indefinidamente mantidos, é ignorar a praticidade que o aprimoramento tecnológico traz aos consumidores. Hoje os music players portáteis são uma realidade. Em tamanhos diminutos, menores que um maço de cigarros, são capazes de armazenar milhares de músicas, das quais apresenta informações variadas, a exemplo do tempo total da música, intérprete, gênero musical e compositor. E a forma principal que os usuários utilizam para preencher as memórias de tais aparelhos é mediante a troca de arquivos, seguida pela aquisição por meio de sítios legais e pela importação de faixas musicais constantes dos CDs de sua propriedade. Esse tema será objeto de análise pontual adiante, em tópico específico.

A quarta razão exposta pela autora italiana é "a falta da percepção do ilícito pelo público". Realmente, num primeiro momento o público não se deu conta da ilicitude da conduta em baixar músicas pela internet sem a autorização do(s) respectivo(s) titular(es) e passou a fazê-lo sem qualquer temor. Somente após algum tempo é que a indústria fonográfica e os titulares dos direitos autorais traçaram estratégias (que adiante serão analisadas) de combate ao que chamam de "pirataria virtual", por intermédio de ações judiciais exemplares contra serviços on-line e usuários comuns, bem como campanhas publicitárias. O fato é que toda uma nova geração já foi acostumada com a troca gratuita de arquivos e considera que deveria ser legal o compartilhamento de músicas com outros usuários, sem o pagamento de direitos autorais ${ }^{332}$, e isso é algo que não pode ser desconsiderado. É o que Françoise Benhamou e Joëlle Farchy denominam "cultura da gratuidade", forma de acesso à cultura tornada possível graças à internet ${ }^{333}$.

Outrossim, mesmo atualmente, muito embora o grande esforço de marketing das gravadoras em demonstrar a ilicitude da utilização de novas tecnologias para a troca não

332 "A 2003 Harris Interactive survey of teens showed that roughly three out of four teens feel that it should be legal to share music files with each other without making any extra payments to the right holders." (KUSEK e LEONHARD, The future of music..., p.101).

333 "Avec la création en 1998 du site Napster par um étudiant américain, c'est em effet toute une génération qui se prend à rêver d'une autre forme d'accès à la culture grâce à Internet, accès gratuit à um potentiel infini d'œuvres du monde entier." (BENHAMOU e FARCHY, Droit d'auteur..., p.57). 
autorizada de obras protegidas pelos direitos autorais, a maior parte daqueles que fazem uso do P2P não se considera infratora, pelo fato de utilizar as músicas de forma privada, para seu deleite pessoal.

Entretanto, o que muito interessa ao presente estudo é que tal forma de aquisição de obras musicais, operada por meio de transferências de músicas por redes ponto-a-ponto, diretamente executada pelos usuários, em grande parte é levada a efeito em infração aos direitos autorais, conforme a normativa autoral vigente.

Utilizando-se de distinção cara ao pensamento de Pontes de Miranda, pode-se dizer que a incidência das regras jurídicas e a subseqüente constituição do ato jurídico ilícito ocorrem independentemente da consciência e, ainda mais, da concordância a respeito das regras jurídicas incidentes. No caso, no entanto, não se pode negar a fratura que existe entre a eficácia das regras jurídicas de direito do autor e a eficácia social desse modelo de proteção autoral ${ }^{334}$.

\subsubsection{Aspectos jurídicos do compartilhamento de músicas pelas redes ponto-a-ponto}

Insta salientar, desde já, que tanto sob a ótica do direito brasileiro quanto do direito estrangeiro, a operação de tecnologia de compressão MP3, ou qualquer outra, bem como a tecnologia P2P são em si lícitas, do mesmo modo que sua utilização, quando relacionadas a objetos não protegidos por direitos autorais de terceiros ou, caso o sejam, se devidamente licenciados ${ }^{335}$.

Outrossim, cabe notar que o caráter dúplice do direito de autor, previsto na lei brasileira, mormente a proteção aos direitos morais, é fator relevante e diferenciador em relação aos países onde as leis não a contemplam, uma vez que no ciberespaço a ausência de fronteiras físicas traz consigo diferentes estatutos e interpretações, de modo a ser freqüente que usuários dos serviços $\mathrm{P} 2 \mathrm{P}$ infrinjam tanto direitos patrimoniais de autor quanto também direitos morais, já que, dentre outras possíveis infrações, é muito comum a ausência ou

334 Sobre o assunto, cf. PONTES DE MIRANDA. José Cavalcanti. Tratado de direito privado. 3.ed. Rio de Janeiro: Borsoi, 1970. Tomo I. p.74 e segs.; BERNARDES DE MELLO, Marcos. Teoria do fato jurídico: plano da existência. 13.ed. São Paulo: Saraiva, 2007. p.235 e segs.

335 Nesse sentido Françoise Benhamou e Joëlle Farchy: "Cepedant, la technologie du P2p n'est pás illégale en soi. L'utilité de sés applications possibles es incontestable. Il est donc nécessaire de distinguer la technique, neutre sur le plan juridique, de l'utilisation qui en est faite". (BENHAMOU e FARCHY, Droit d'auteur..., p.62). 
incorreta atribuição de paternidade de uma obra musical quando do compartilhamento de arquivos, o que infringe o art. 24, I e II da lei autoral brasileira, por exemplo ${ }^{336}$.

A infração aos direitos morais ocorre porque, na maioria das vezes, o usuário-amador é o que faz a transferência da obra musical de um CD (ou mesmo LP) para um arquivo digital e sua posterior compressão e, também, acaba por preencher os dados referentes ao título, autoria, interpretação etc., muitas vezes sem a devida atenção.

No estágio atual dos acontecimentos, é praticamente impossível ao criador de obras musicais controlar ou mesmo buscar corrigir tal infração em relação à paternidade da obra. Uma possibilidade é que, no futuro, adicionalmente a uma eventual "regularização" do P2P, seja adotado um mecanismo padrão, igualmente tecnológico, que contenha um banco de dados de obras musicais, o qual automaticamente preencha de forma correta os campos de informações sobre as músicas ou corrija as informações errôneas já inseridas ${ }^{337}$.

Outro ponto que traz discussões acerca do direito moral do compositor é a questão da fragmentaridade da obra digital. Em se tratando de fixação em seqüência de códigos binários, é muito simples a operação de alterar determinada obra à revelia do autor, descaracterizando-a em desrespeito ao direito à integridade de sua obra ${ }^{338}$.

De todo modo, o que efetivamente causa embates na utilização da tecnologia P2P para transmissão de obras musicais, sob o enfoque dos direitos autorais, é o aspecto patrimonial, uma vez que, via de regra, as gravadoras é que são as titulares tanto dos direitos patrimoniais de uma composição quanto dos direitos conexos referentes aos fonogramas e

336 LDA: "Art. 24. São direitos morais do autor:

I - o de reivindicar, a qualquer tempo, a autoria da obra;

II - o de ter seu nome, pseudônimo ou sinal convencional indicado ou anunciado, como sendo o do autor, na utilização de sua obra";

337 Podem ser utilizadas tecnologias já desenvolvidas, que reconhecem e identificam as músicas contidas em $\mathrm{CD}$ e arquivos digitais. A mais conhecida é a Gracenote MusicID, desenvolvida e licenciada pela empresa Gracenote, que oferece, ainda, diversos e inovadores serviços tanto para profissionais da música quanto para os usuários. Também oferecem tais soluções tecnológicas a Yahoo e a Microsoft.

338 "Estreitamente ligada a esta questão está uma outra, de saber em que medida será possível, no novo contexto tecnológico, respeitar o direito moral do autor à paternidade e, particularmente, a integridade da obra, em razão da fragmentaridade das obras sob forma digital. Com efeito, uma característica típica da tecnologia digital é justamente o facto de as obras digitalizadas poderem ser facilmente modificadas, desintegradas, reformatadas ou combinadas. Se por diversas razões, pelo menos actualmente, ainda existem alguns limites de ordem técnica (por ex., um leitor normal de CD não permite, em regra, tirar os dados digitais gravados no $\mathrm{CD}$ ), a prazo, será problemático assegurar o direito moral do autor no ambiente digital dos sistemas informáticos em rede, com o desaparecimento das copias materiais." (PEREIRA, Informática, direito..., p.403). 
lhes é conferida uma série de normas protetoras, oriundas do direito internacional e presentes nos regramentos internos dos países.

Se num passado próximo poder-se-ia alegar a imprevisão normativa quanto à utilização das redes P2P para a disseminação de arquivos contendo obras musicais cujos titulares não a autorize, na atualidade se demonstra desafio hercúleo a defesa de sua licitude, sob o prisma do direito positivo, já que não somente houve alteração legislativa para abranger os novos meios, mas o recrudescimento da lei, inclusive com a criminalização do usuário que violar direitos autorais, diminuindo-se progressivamente as limitações ou exceções a tais direitos.

A premissa da tecnologia ponto-a-ponto é que os usuários entre si troquem arquivos contendo informações, cada qual se responsabilizando pela licitude dos arquivos que disponibilizam para upload. Assim, se o arquivo contém uma obra musical cujo titular não tenha autorizado que terceiros a disponibilizem em rede ou por qualquer outra forma, quem o faz infringe direitos patrimoniais.

Num estudo de caso hipotético, o usuário "A" tem em seu computador, para compartilhar com outros usuários, a faixa musical "Brasil", de autoria de "B", interpretada por "C", cujo fonograma é de titularidade da gravadora "X". "A" está conectado a uma rede ponto-a-ponto, a mesma que o usuário "E", que pesquisa justamente pela música "Brasil". O software informa ao usuário "E" que cinco usuários on-line têm a música em seus microcomputadores, pelo que "E" decide fazer o download para seu microcomputador. O software administra a transferência de modo que, simultaneamente, esses cinco usuários passem a ser os fornecedores, fazendo com que o processo de transmissão seja ainda mais rápido, já que cada microcomputador que faz o upload envia somente fragmentos do arquivo digital contendo a música.

Dessa forma, no caso em tela, seis usuários diferentes se envolvem na troca de um arquivo: cinco ("A" mais quatro outros) na qualidade dos que fazem o upload - os fornecedores - e um ("E") na qualidade do que faz o download - o receptor. Ressalte-se que nenhum dos usuários tem noção de quem seja o outro, bem como podem estar situados em diferentes locais do planeta. O fato é que, conforme já visto no primeiro capítulo deste estudo, a proteção aos direitos patrimoniais veda tal oferta, quando não autorizada por quem detenha a titularidade, originária ou derivada, da obra musical. 
É perceptível a infração aos direitos de reprodução e de distribuição, quer seja dos autores, quer dos intérpretes, quer dos produtores de fonogramas ${ }^{339}$. Infringem-se os direitos de reprodução na medida em que há a cópia não-autorizada dos arquivos que contêm a obra musical digitalizada, o que caracteriza a contrafação.

Do mesmo modo, infringem-se os direitos de distribuição em vista da disponibilização ao público de obra musical digitalizada, que o usuário faz a partir de seu computador, e da efetiva transferência de posse do arquivo que a contém. Poder-se-ia, entretanto, aventar que tal interpretação seria drástica, uma vez que a distribuição deveria ter caráter preponderantemente lucrativo, o que não é o caso do compartilhamento de arquivos entre usuários, motivo pelo qual seria lícita tal transferência, se feita entre eles.

Mas esse último entendimento não prevalece, no mínimo por três razões. Primeiro, não há menção de que seja necessária a presença do caráter lucrativo para que ocorra a distribuição. Ao contrário, o art. 5, IV da LDA menciona "venda, locação ou qualquer outra forma de transferência de propriedade ou posse", sendo certo que "qualquer outra forma de transferência" pode muito bem abranger a doação. Segundo, em que pese não haver caráter lucrativo, é certo que existe caráter econômico, em vista de que estão em jogo direitos patrimoniais. Terceiro, o legislador fez incluir no art. 107, IV da lei autoral ${ }^{340}$, que trata das sanções, a expressão "puser à disposição do público", além do ato de distribuir, com o que incorreu em repetição que denota o firme intuito de barrar qualquer outra interpretação ${ }^{341}$.

Assim, parece claro que, pela incidência das regras de direito positivo, ocorre o fato jurídico ilícito civil quando há distribuição não-autorizada de obras musicais ou fonogramas pelos sistemas de redes P2P, mesmo quando levadas a efeito pelos usuários.

Também, da interpretação da norma penal pode-se entender que tal conduta constitui ilícito penal. Isso se dá tanto pela interpretação da antiga redação do art. 184 do

339 É o disposto nos artigos 28 e ss. e 89 e ss. da LDA.

340 LDA, "Art. 107. Independentemente da perda dos equipamentos utilizados, responderá por perdas e danos, nunca inferiores ao valor que resultaria da aplicação do disposto no art. 103 e seu parágrafo único, quem: IV - distribuir, importar para distribuição, emitir, comunicar ou puser à disposição do público, sem autorização, obras, interpretações ou execuções, exemplares de interpretações fixadas em fonogramas e emissões, sabendo que a informação sobre a gestão de direitos, sinais codificados e dispositivos técnicos foram suprimidos ou alterados sem autorização".

341 Em que pese o fato de tal artigo tratar de sanções a quem burla informações de gestão de direitos e mecanismos tecnológicos de proteção, 
Código Penal, vigente a partir de $1993^{342}$, que ampliou o alcance da norma ao imputar como típica a conduta de reproduzir fonograma, quanto, e principalmente, pela atual redação, introduzida pela Lei n. ${ }^{0} 10.695 / 2003^{343}$, que ampliou os atos tipificados, imputando aos agentes infratores a pena de reclusão, por dois a quatro anos.

Da leitura da formulação original do art. 184, que remonta a $1940^{344}$, percebe-se que a norma era mais branda e não tipificaria a conduta dos usuários. Atualmente, porém, não somente o regramento civil foi alterado em favor dos detentores dos direitos autorais, mas a norma penal pode também atingir o usuário de músicas, a depender da interpretação a ser dada pelo Poder Judiciário. Afinal, no que consistiria o lucro indireto constante nos parágrafos $1 .^{\circ}, 2 .^{\circ}, 3 .^{\circ}$ e $4 .^{\circ}$ do art. 184 do Código Penal, em sua versão atual?

342 Decreto Lei n. ${ }^{\circ}$ 2.848/1940, com redação da Lei n. ${ }^{\circ} 8.635 / 1993$ : "Art. 184. Violar direito autoral: Pena detenção de três meses a um ano, ou multa de $\mathrm{Cr} \$ 2.000,00$ a $\mathrm{Cr} \$ 10.000,00$.

$\S 1{ }^{\circ}$ Se a violação consistir em reprodução, por qualquer meio, com intuito de lucro, de obra intelectual, no todo ou em parte, sem autorização expressa do autor ou de quem o represente, ou consistir na reprodução de fonograma ou videofonograma, sem a autorização do produtor ou de quem o represente: Pena - reclusão, de um a quatro anos, e multa, de $\operatorname{Cr} \$ 10.000,00$ (dez mil cruzeiros) a $\operatorname{Cr} \$ 50.000,00$ (cinqüenta mil cruzeiros).

$\S 2{ }^{\circ} \mathrm{Na}$ mesma pena do parágrafo anterior incorre quem vende, expõe à venda, aluga, introduz no País, adquire, oculta, empresta, troca ou tem em depósito, com intuito de lucro, original ou cópia de obra intelectual, fonograma ou videofonograma, produzidos ou reproduzidos com violação de direito autoral.

$\S 3 .^{\circ}$ Em caso de condenação, ao prolatar a sentença, o juiz determinará a destruição da produção ou reprodução criminosa."

343 Decreto Lei n. ${ }^{\circ}$ 2.848/1940, sob alteração da Lei 10.965/2003: "'Art. 184. Violar direitos de autor e os que lhe são conexos: Pena - detenção, de 3 (três) meses a 1 (um) ano, ou multa.

$\S 1 .^{\circ}$ Se a violação consistir em reprodução total ou parcial, com intuito de lucro direto ou indireto, por qualquer meio ou processo, de obra intelectual, interpretação, execução ou fonograma, sem autorização expressa do autor, do artista intérprete ou executante, do produtor, conforme o caso, ou de quem os represente: Pena - reclusão, de 2 (dois) a 4 (quatro) anos, e multa.

$\S 2 .{ }^{\circ} \mathrm{Na}$ mesma pena do $\S 1 \mathrm{o}$ incorre quem, com o intuito de lucro direto ou indireto, distribui, vende, expõe à venda, aluga, introduz no País, adquire, oculta, tem em depósito, original ou cópia de obra intelectual ou fonograma reproduzido com violação do direito de autor, do direito de artista intérprete ou executante ou do direito do produtor de fonograma, ou, ainda, aluga original ou cópia de obra intelectual ou fonograma, sem a expressa autorização dos titulares dos direitos ou de quem os represente.

$\S 3 .^{\circ}$ Se a violação consistir no oferecimento ao público, mediante cabo, fibra ótica, satélite, ondas ou qualquer outro sistema que permita ao usuário realizar a seleção da obra ou produção para recebê-la em um tempo e lugar previamente determinados por quem formula a demanda, com intuito de lucro, direto ou indireto, sem autorização expressa, conforme o caso, do autor, do artista intérprete ou executante, do produtor de fonograma, ou de quem os represente: Pena - reclusão, de 2 (dois) a 4 (quatro) anos, e multa. $\S 4 .^{\circ} \mathrm{O}$ disposto nos $\S \S 1 .^{\circ}, 2 .^{\circ}$ e $3 .^{\circ}$ não se aplica quando se tratar de exceção ou limitação ao direito de autor ou os que the são conexos, em conformidade com o previsto na Lei n. ${ }^{\circ} 9.610$, de 19 de fevereiro de 1998, nem a cópia de obra intelectual ou fonograma, em um só exemplar, para uso privado do copista, sem intuito de lucro direto ou indireto."

344 Decreto-Lei n. ${ }^{\circ}$ 2.848/1940: "Art. 184. Violar direito de autor de obra literária, científica ou artística: Pena - detenção de três meses a um ano, ou multa, de um conto a cinco contos de réis.

Parágrafo único. Na mesma pena incorre quem vende ou expõe à venda, adquire, oculta ou tem em depósito, para o fim de venda, obra literária, científica ou artística, produzida com violação de direito autoral". 
Parece claro que aquele que disponibiliza as músicas em um sítio e, mediante pagamento, autoriza a transferência para outros computadores exerce atividade que caracteriza a busca do lucro direto. Na opinião de Ronaldo Lemos, em livro publicado a partir de tese de doutoramento em direito defendida na Faculdade de Direito da USP ${ }^{345}$ :

\begin{abstract}
Nesse sentido, a interpretação de lucro direto ou indireto pode e deve ser restringida, para compreender lucro apenas como resultado econômico de atividade empresarial, tal como o conceito é tratado, por exemplo, na legislação tributária ou na legislação societária. Assim, a interpretação razoável é de que lucro corresponde ao resultado da atividade do empresário, que organiza os fatores de produção, obtendo ganho que supera o investimento organizacional. Ele é direto quando auferido pelo próprio empresário e indireto quando beneficia outrem.
\end{abstract}

A questão do lucro direto ou indireto em direitos autorais, mormente em relação à execução musical, foi objeto de muita discussão nos tribunais superiores, quando da vigência da Lei n. ${ }^{\circ} 5.988 / 73$, a qual, no seu art. $73^{346}$, condicionava à necessidade de autorização do autor a transmissão, representação ou execução somente nos casos de lucro direto ou indireto, o que foi alterado na Lei . $^{0}$ 9.610/98, art. $68^{347}$, hoje vigente, que torna desnecessário o intuito lucrativo.

Com base na lei anterior, o Supremo Tribunal Federal, em Recurso Extraordinário sob relatoria do Ministro Moreira Alves ${ }^{348}$, sinalizou entendimento sobre a questão em caso que envolvia a execução musical praticada em clube sem fins lucrativos. Muito embora tal recurso não tenha sido conhecido por motivo formal (dissídio jurisprudencial não comprovado),

345 LEMOS, Direito, tecnologia..., p.164.

346 Lei n. ${ }^{\circ}$ 5.988/73: "Art. 73. Sem autorização do autor, não poderão ser transmitidos pelo rádio, serviço de alto-falantes, televisão ou outro meio análogo, representados ou executados em espetáculos públicos e audições públicas, que visem a lucro direto ou indireto, drama, tragédia, comédia, composição musical, com letra ou sem ela, ou obra de caráter assemelhado."

347 Lei n. ${ }^{\circ}$ 9.610/98: "Art. 68. Sem prévia e expressa autorização do autor ou titular, não poderão ser utilizadas obras teatrais, composições musicais ou lítero-musicais e fonogramas, em representações e execuções públicas."

348 "DIREITOS AUTORAIS. ARTIGO 73 DA LEI 5988/73. LUCRO INDIRETO. - FALTA DE PREQUESTIONAMENTO DA QUESTÃO RELATIVA_AO PARAGRAFO 2 DO ARTIGO 153 DA CONSTITUIÇÃO FEDERAL (SÚMULA 282 E 356). - - A ADOÇÃO DE CONCEITO AMPLO DE LUCRO INDIRETO NÃO CONFIGURA INTERPRETAÇÃO DESARRAZOADA DO ARTIGO 73 DA LEI 5.988/73. APLICAÇÃO DA SÚMULA 400. - DISSIDIO DE JURISPRUDÊNCIA NÃO DEMONSTRADO COMO O EXIGE O ARTIGO 322, 'CAPUT', DO REGIMENTO INTERNO DESTA CORTE. RECURSO EXTRAORDINÁRIO NÃO CONHECIDO. RE 104157 / MG - MINAS GERAIS RECURSO EXTRAORDINÁRIO Relator(a): Min. MOREIRA ALVES Julgamento: 11/12/1984, Órgão Julgador: Segunda Turma". [grifo nosso] 
o relator fez constar que "ademais, toda a questão, em verdade, se prende à interpretação da expressão 'lucro indireto' que se encontra no artigo 73 da Lei 5.988/73".

Em seu voto, indicou o Ministro do STF que "não é desarrazoado" o conceito amplo adotado na decisão de primeiro grau, referendada pelo acórdão do TJ/MG, no sentido de que "lucro indireto é aquele que significa qualquer forma de proveito", inclusive no caso de um clube social sem fins lucrativos, mas que eventualmente pode locar seus salões a terceiros não-associados.

No mesmo sentido, o Superior Tribunal de Justiça editou a Súmula 63, como seguinte enunciado: "são devidos direitos autorais pela transmissão radiofônica de músicas em estabelecimentos comerciais", mediante o entendimento da ocorrência de lucro indireto com a captação de clientela que a execução musical ambiente proporciona.

Diante do já existente entendimento - e indicativo - dos tribunais superiores em torno do amplo significado da expressão "lucro indireto", mormente aquela do STF acerca de "qualquer forma de proveito" é que se suscita o questionamento se os usuários dos serviços P2P seriam atingidos pela norma penal, uma vez que estariam tirando proveito de obras musicais sem o pagamento de contraprestação autoral.

Importante notar, entretanto, que os casos decididos nos tribunais superiores não tinham como parte pessoas físicas (usuários) de músicas mas sim pessoas jurídicas, do mesmo modo que a revogada letra do art. 73 da lei autoral anterior tratava da execução pública. Isso terá de necessariamente ser levado em conta na eventualidade de acusação penal de usuário na interpretação do atual tipo penal. A expressão "lucro indireto" daquelas decisões era aplicada num contexto completamente diverso daquele que hoje seria hipoteticamente aplicado em relação ao usuário, em que o suposto lucro indireto seria presente pelo chamado substitution effect (efeito de substituição), já que deixaria de pagar pelas aquisição das músicas. É uma interpretação que - espera-se - não tenha vez na perspectiva penal.

O fato é que a troca de arquivos pelas redes P2P foi o que motivou os titulares de direitos autorais a efetivamente voltarem seu olhos para a internet. Ao mesmo tempo que perceberam o enorme mercado que até então ignoravam, constataram o grande volume de transferências não-autorizadas de arquivos. 
Passado o susto inicial, a indústria fonográfica partiu para o contra-ataque, por intermédio da RIAA - Record Industry American Association ${ }^{349}$, ente associativo que congrega mais de $90 \%$ das sociedades empresárias estadunidenses atuantes no segmento fonográfico, que passou a liderar as ações com vistas a inibir a utilização da internet como meio de infração aos direitos autorais.

Sob a justificativa de proteger investimentos futuros da indústria fonográfica em novas bandas e músicas e de garantir condições para o desenvolvimento do que denomina "negócios on-line legais", a RIAA busca conscientizar os usuários ${ }^{350}$, mostrando-lhes a opção - que também constitui espécie de alerta - de "pagar pouco agora ou muito mais depois"351. Em paralelo, tal associação oferece a suas associadas suporte jurídico para as tentativas de fazer aplicar os respectivos direitos autorais, representando-as nas cortes estadunidenses.

Foi assim que, com base na lei americana Digital Millenium Copyright Act (DMCA), de 1998, a RIAA decidiu processar, num primeiro momento, os fomentadores de serviços P2P e, ao perceber que tais ações não surtiram o efeito necessário, já que diversos outros serviços similares surgiam a cada vez que conseguiam fazer um deles cessar, optou por processar diretamente, de forma exemplar, os usuários de tais serviços.

349 Em vernáculo, Associação Americana da Indústria Fonográfica.

350 "The ultimate goal with all our anti-piracy efforts is to protect the ability of the recording industry to invest in new bands and new music and to give legal online services a chance to flourish. That's why we educate. That's why record companies license music to legal services. And that's why, when necessary, we enforce our rights through the legal system". (RIAA, Record Industry American Association. Disponível em: <http://www.riaa.org/faq.php>. Acesso em: 2 nov. 2007).

351 "Suing individuals was by no means our first choice. Unfortunately, without the threat of consequences, far too many people were just not changing their behavior. Education alone was not enough to stem the extraordinary growth of illegal P2P use. While we have been filing lawsuits against individuals since September 2003, our first preference continues to be targeting the businesses that encourage and profit from theft. That said, it is critical that we simultaneously send a message to individuals that engaging in the theft of music is illegal.

If a store owner catches someone shoplifting merchandise, you can bet that owner takes action - just as he or she should. Our lawsuits against individuals engaged in music theft are no different. Illegal downloading is not a victimless crime: thousands of record label employees have been laid off, hundreds of artists have been cut from label rosters, numerous record stores are closing throughout the country, and due to declining sales, record companies are finding their ability to invest in new artists at risk. With so many great legal ways to enjoy music online, there's no excuse for downloading music illegally. That's why we will continue to take a tough line against people who steal music. It's theft, it's illegal and there can be real consequences. Legal downloading doesn't cost much. Every fan has a choice: pay a little now or a lot more later." (RIAA, Record Industry American Association. Disponível em: $<$ http://www.riaa.org/faq.php>. Acesso em: 2 nov. 2007). 
Dentre os serviços P2P, o caso mais famoso foi o do Napster. Em 1998, um estudante universitário desenvolveu um sistema que tornava disponíveis, a partir do microcomputador de um usuário, arquivos digitais contendo músicas para que outro pudesse baixá-los, assim como possibilitava a busca da música pretendida e providenciava a operação de transferência dos $\operatorname{arquivos}^{352}$.

A idéia surtiu tanto efeito que foi constituída uma sociedade empresária denominada Napster cujo objeto era a oferta e exploração do software e correspondentes serviços que possibilitavam o compartilhamento de arquivos, tendo sido o primeiro sistema eficiente de P2P para a troca de músicas.

Ocorre que a indústria fonográfica não viu com bons olhos mais essa ameaça, ao lado das tantas outras que surgiam na internet. A RIAA ingressou contra o Napster em 6 de dezembro de 1999 sob a acusação de pirataria em larga escala, pedindo a condenação por violação de direitos autorais por sua responsabilidade em vista de fatos de terceiros, mediante a aplicação das formas típicas do direito estadunidense da "vicarious liability" e do "contributory infringement"353.

Nas palavras de Deborah De Angelis:

\begin{abstract}
A primeira, a vicarious liability, é uma forma de responsabilidade indireta segunda a qual um terceiro responde pelos ilícitos cometidos por um sujeitoagente, nos limites os quais ao mesmo seja solicitado e, de fato, possa exercitar um poder de controle (p.ex. o direito e a habilidade de supervisionar) sobre a atividade do agente e que tal atividade lhe traga uma vantagem econômica.

$\mathrm{O}$ contributory infringement, ao contrário, garante ao titular do direito de autor uma defesa contra o terceiro, o qual, ciente (seja em termos de efetiva consciência, seja de previsibilidade) da atividade ilícita efetuada pelo sujeito-agente, induz, causa e contribui materialmente ao cometimento do ato ilícito do outro. ${ }^{354}$
\end{abstract}

352 Baseado na decisão da Corte de Apelações do 9. ${ }^{\circ}$ Circuito dos Estados Unidos da América, p.4.

353 Cf. De ANGELIS, La tutela giuridica..., p.26.

354 Tradução livre de "la prima, la vicarious liability, è una forma di responsabilità indiretta secondo la quale un terzo risponde degli illeciti compiuti dal soggetto agente, nei limiti in cui allo stesso sia richiesto e, di fatto, possa esercitare un potere di controllo (c.d. the right and the ability to supervise) sull'attività dell'agente e da tale attività egli tragga un vantaggio economico. Il contributory infringement, invece, garantisce al titolare del diritto d'autore una difesa contro il terzo, il quale, consapevole (sia in termini di effettiva conoscenza, sia di prevedibilità) dell'attività illecita effettuata dal soggetto agente, induca, causi e contribuisca materialmente al compimento di altrui condotte illecite" (De ANGELIS, La tutela giuridica..., p.26). 
A Napster contestou, refutando as acusações e afirmando ser apenas um meio para que os usuários diretamente perfizessem as trocas de arquivos e que não poderia controlar a licitude do que é transmitido, o que inclusive feriria o direito à privacidade dos usuários, dentre outros argumentos.

O fato é que em junho de 2000 diversas gravadoras entraram com ação cautelar, perante o mesmo juízo, requerendo a determinação de cessação do serviço, no que obtiveram êxito, já que em 26 de julho de 2000 foi-lhes concedida a liminar requerida. Iniciou-se batalha jurídica na qual o Napster reiteradamente perdeu, sempre com o serviço fora de funcionamento, até que em 2003 foi firmado acordo entre as partes, no valor de 26 milhões de dólares estadunidenses. A marca e o nome de domínio foram vendidos ao grupo de tecnologia Roxio e atualmente atua sob a forma de companhia aberta em bolsa (Nasdaq) ${ }^{355}$, oferecendo serviços de rádio on-line e de download "legal" de músicas, tendo abandonado o sistema P2P.

É interessante notar que diversos outros serviços de P2P já estavam ativos naquela época - e continuam ativos atualmente -, mas conseguiram escapar dos argumentos da RIAA, uma vez que, ao contrário do Napster, não utilizavam um servidor central, mas tãosomente ofereciam - e oferecem - software e suas atualizações. São alguns desses serviços o I-Mesh, KaZaa, LimeWire, Aimster, dentre outros.

Esse caso do Napster tem grande significado em vista de ter demonstrado a grande divisão de forças: de um lado as gravadoras e associações de propriedade intelectual, de outro associações de usuários e acadêmicos, todos na qualidade de amici curiae. Demonstra, também, que nos tempos atuais de nada adianta simplesmente tirar um serviço de funcionamento, que outros tantos serão lançados e aprimorados. O que tem de haver é a mudança de concepção, que acompanhe as mudanças sociais.

355 "Napster (NASDAQ: NAPS) is committed to making great music experiences more accessible to all music fans. Napster.com gives web users the power to legally listen on-demand to a massive catalog of music from major and independent labels, wherever they are on the Web-for FREE. The Napster music subscription service offers a premium experience that includes unlimited access to CD-quality music and advanced discovery, community and programming features in an advertising-free environment, and Napster To Go subscribers also enjoy unlimited transfer of music to a compatible MP3 player. Napster Light, an a la carte download store, and Napster Mobile, a hosted music service featuring artist images, ring tones and full-length songs, round out the Napster digital music lineup. Napster is headquartered in Los Angeles with offices in Frankfurt, London, Luxembourg, New York, San Diego and Tokyo." Disponível em: <http://www.napster.com/about_napster.html>. Acesso em: 10 December 2007. 


\section{CAPÍTULO 3}

\section{DIREITOS AUTORAIS VERSUS DIREITO DE ACESSO AOS BENS CULTURAIS: TENDÊNCIAS E PROPOSTAS}

\subsection{DA INDÚSTRIA FONOGRÁFICA AO MERCADO MUSICAL: NOVAS FORMAS DE UTILIZAÇÃO DA OBRA MUSICAL}

Foi constatado que a indústria fonográfica atravessa forte crise e tenta defender seu modelo de negócios com todas as forças. O fato é que ela se sente ameaçada pela queda nas receitas representada pela venda dos CDs, que justifica como motivada tanto pela pirataria física quanto pela pirataria on-line $e^{356}$. Diante disso, passou a pressionar os governos nacionais para que firmassem tratados internacionais que prevêem obrigações às partes em recrudescer as sanções nas respectivas leis autorais.

Assim, além de ingressar com demandas em face de sociedades empresárias que de alguma forma disponibilizam música na internet e usuários comuns que os adquirem sem o pagamento de contraprestação, passou a promover intensa campanha publicitária, pretendendo incutir nos consumidores a idéia de que o ramo musical como um todo seria extinto em virtude da pirataria. Noutras palavras, segundo as gravadoras: se as coisas continuassem como estavam, não haveria mais música.

Tal alarmista concepção se demonstrou, porém, equivocada. E não surtiu resultado. Com efeito, a indústria fonográfica pode até deixar de existir tal qual no modelo

356 É errôneo atribuir a queda na receita proveniente dos CDs tão-somente à pirataria física e on-line. Existe uma série de outros fatores que contribuem para isso, a começar pela facilidade que os usuários têm de escutar suas músicas gratuitamente pela internet, através de rádios on-line devidamente autorizadas pelos titulares de direitos autorais. Ainda, as pessoas em geral gastam seu tempo com outras formas de lazer, de modo que redirecionaram o dinheiro que antes gastavam comprando CDs. David Kusek e Gerd Leonhard apresentam uma série de outros motivos para o declínio de tais vendas: "we believe that the reasons for the decline in CD sales have very little to do with illegal file-sharing, and a great deal more to do with the way that music has been marketed and distributed for the past eight to ten years. These reasons include the significantly reduced number of retail outlets that carry CDs, the by-and-large noncompetitive pricing of CDs and digital singles, the labels' unwillingness to experiment and develop really different artists, and the many competing forms of entertainment that exert magnetic power over the disposable dollars of the consumers, including video games, wireless services, and DVDs. And, let's not forget to mention that we have finally reached the end of that glorious replacement cycle of vinyl-to-CD that the industry has happily gorged itself on for the past fifteen to twenty years. Add to that the music fans' increasing awareness of the unfair way that record companies have treated artists, and you have some very good reasons as to why sales are down" (KUSEK e LEONHARD, The future of music..., p.81). 
reinante até os dias atuais, mas a existência da música em si nunca dependeu de qualquer modelo de negócios.

A conseqüência disso foi a mudança de enfoque da própria indústria, o que se percebeu no estudo anual que a IFPI faz publicar acerca dos dados do setor ${ }^{357}$, no qual seu presidente explicitamente reconhece as mudanças ocorridas e sua complexidade. Os efeitos dessa percepção já estão começando a surgir, pois as gravadoras e demais titulares de direitos agora não somente atuam na repressão, mas também na busca de alternativas viáveis de negócios, conforme será visto no decorrer deste tópico.

De qualquer forma, não faria sentido que a indústria fonográfica, de maneira cega, insistisse em simplesmente negar os novos tempos e mantivesse integralmente o modelo de negócios até então adotado. Assim é que ela está dando amplo reconhecimento do mercado musical ${ }^{358}$, gênero da qual é espécie e no qual mantém a sua participação, mesmo que não absoluta como antes.

Mesmo assim, o desenho de futuro da indústria fonográfica se demonstra uma incógnita, enquanto no mercado musical o cenário se demonstra profícuo, em vista das inúmeras possibilidades abertas com as novas tecnologias ${ }^{359}$. É o que defendem David Kusek e Gerd Leonhard para quem "mas se alguém olha além das vendas de CDs, fica claro que, de modo

357 KENNEDY, John. The evolving business of music. In: Recording Industry in Numbers. London: IFPI, 2007. p.3.

358 Existe ampla discussão a respeito da noção de mercado. Sob uma perspectiva "naturalista", o mercado seria o produto de uma natural relação entre fornecedores e consumidores que, buscando maximizar seus proveitos, racionalmente dirigiriam suas escolhas viabilizando uma situação de estabilidade. A concepção naturalista de mercado tem sido alvo de críticas, destacando-se, nesse sentido, o entendimento de Natalino Irti, segundo o qual inexistiriam mercados fora de específicas escolhas políticas e jurídicas que conformariam seu funcionamento. Assim, não se poderia falar propriamente de um "mercado" universal e abstrato e sim de inúmeros "mercados", conformados pelas escolhas realizadas em determinado tempo e espaço. Na medida em que a música passa a ser ofertada como produto ou serviço, viabilizando relações entre consumidores e fornecedores neste setor, pode-se mencionar a existência de um mercado musical que, tal como alinhavado por Irti, encontra-se sujeito não apenas às potenciais condutas de consumidores e fornecedores, mas também é fruto de escolhas políticas, jurídicas e, neste caso, por vezes para além delas, das inovações tecnológicas conforme demonstrado ao longo da tese. Sobre a noção de mercado em sua concepção naturalista e a crítica de Natalino Irti, cf. LEONARDO, Rodrigo Xavier. Redes contratuais no mercado habitacional. São Paulo: Revista dos Tribunais, 2003. p.66 e segs.

359 "Contrary to what we've been hearing for the past three years, the music business is still in very good shape today. The problem is with the record industry and CD sales." (KUSEK e LEONHARD, The future of music..., p.6 
geral, o mercado musical está vibrante e ativo. Mais música tem sido apreciada nos últimos dois ou três anos que nunca dantes, multiplicado por dois ou mais"360.

Nesse contexto, a tecnologia abriu um variado leque de oportunidades aos artistas, que não mais necessitam convencer executivos de gravadoras de que podem vir a fazer sucesso. Atualmente, com um microcomputador portátil, uma banda musical consegue gravar suas obras com excelente qualidade, assim como fixá-las em CD ou armazená-las em um dos muitos sítios da internet que possibilitam tal operação. As ferramentas para o eficaz alcance do público usuário se fazem disponíveis, de forma gratuita ou a um custo baixo, e, numa segunda etapa, já com o êxito nas atividades musicais, podem os intérpretes contratar com alguma gravadora, se assim o desejarem, para contar com o know how por ela acumulada e com sua estrutura profissional, ou ainda utilizarem um dos novos serviços de agenciamento virtual de suas carreiras artísticas.

Note-se, outrossim, que a própria denominação, historicamente utilizada, de "gravadora" para designar representante da indústria fonográfica pode demonstrar-se equivocada, uma vez que o papel dos representantes da indústria fonográfica, na atualidade, é o de: i) proporcionar recursos de investimento; ii) utilizar sua experiência em marketing; iii) fornecer os canais de distribuição (físicos e virtuais); e iv) prestar assessoria jurídica, mormente contratual, tratando de licenciar os diversos usos das obras. Já o ato de gravar os discos, quando realizado, é praticado por terceiras empresas, mediante contrato de prestação de serviços ou de licenciamento, dependendo do caso.

Ainda, tem-se notícia de que as representantes da indústria fonográfica agora se voltam também à organização e promoção de shows dos artistas com os quais mantêm contrato, invadindo seara de negócios até então explorada pelos chamados "empresários", agentes ou managers de carreiras artísticas.

De todo modo, percebe-se que a indústria fonográfica, após anos de lutas para a manutenção do status quo finalmente se rendeu aos fatos. A perspectiva que John Kennedy, presidente da poderosa IFPI (International Federation of the Phonografic Industry) ${ }^{361}$ apresenta, na introdução da 14 . $^{\text {a }}$ publicação anual da entidade é emblemática: "nunca antes

360 Tradução livre de "but if one looks beyond CD sales, it is clear that, overall, the music market is vibrant and alive. More music has been enjoyed over the past two or three years than ever before, by a factor of two or more" (KUSEK e LEONHARD, The future of music..., p.6.

361 Federação Internacional da Indústria Fonográfica, em vernáculo. 
o consumo de música foi tão fértil; a música é mais popular do que nunca. Tal demanda é prova de que a qualidade da música está tão boa quanto jamais esteve, mas também que às pessoas está sendo oferecida maior escolha, mais flexibilidade e melhor valor"362.

Ocorre, assim, mudança paradigmática, de "música como sinônimo de gravadora" para "música como objeto de um amplo mercado musical", assim como é perceptível a transferência de poder, antes concentrado na indústria fonográfica e agora pulverizado entre aquela e os intérpretes, compositores, novos empreendedores e, principalmente, usuários.

De tal fato a indústria fonográfica também já tomou conhecimento, a julgar pela afirmação do Presidente da IFPI:

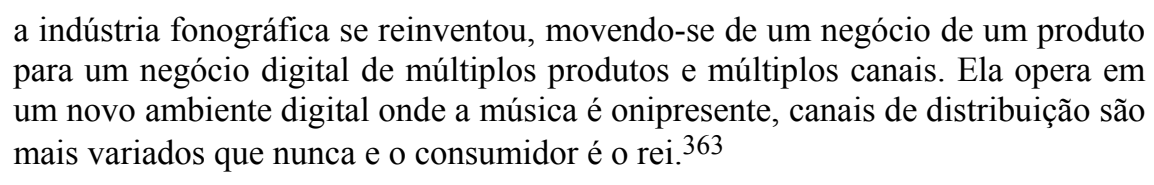

Ainda, com o advento das novas tecnologias e a conseqüente possibilidade de baixar músicas pela internet, mediante pagamento ou de forma gratuita, além de contar com uma variedade muito maior de artistas e músicas, o usuário pode experimentar a sensação de baixar somente as músicas que lhe interessam, sem a necessidade de adquirir o álbum completo. A eficiência e a versatilidade passaram a ter vez. É a opinião do jornalista Sérgio Augusto:

\footnotetext{
Repúdio à tirania dos repertórios dos CDs, por exemplo. Baixar música pela internet não é apenas uma comodidade, mas também uma certeza de que só iremos adquirir as faixas que nos interessam. O barateamento se dá aí: pelo preço de um CD com excesso de gordura, pode-se montar, em casa, um ou mais discos compactos à la carte, só com filé mignon. ${ }^{364}$
}

Por outro lado, os artistas e criadores intelectuais têm o mercado aberto em linha direta com os usuários. Da mesma forma, os empreendedores encontram um sem-número

362 KENNEDY, The evolving business..., p.3. Tradução livre de "never before has music comsumption been so prolific; music is more popular than ever. Such demand is proof that the quality of music is a good as ever, but also that people are being offered greater choice, more flexibility and better value".

363 KENNEDY, The evolving business..., p.3. Tradução livre de "the recording industry has reinvented itself, moving from a one product business to a multi-product, multi-channel digital business. It operates in a new digital environment where music is ubiquitous, distribution channels are more diverse than ever and the consumer is king".

364 AUGUSTO, Sérgio. CDs e lojas de CDs: morte anunciada. O Estado de S. Paulo, São Paulo, 31 mar. 2007, Caderno 2, p.D5. 
de oportunidades de negócios. A questão que se coloca é em relação à conformação das novas condutas dos sujeitos envolvidos com o mercado musical em relação aos direitos autorais: a esses se submeteriam ou os subverteriam?

Daí porque se faz breve análise, sob o prisma jurídico, de alguns exemplos apresentados como tendências em relação à música, introduzidos pelas novas tecnologias.

\subsubsection{Os Sítios de Relacionamento}

Através dos sítios de relacionamento 365 (social networking websites em inglês) os músicos, amadores ou profissionais, podem diretamente expor seus trabalhos artísticos (bem como informações sobre sua vida artística ou mesmo privada) ao público, entabulando uma relação muito mais próxima que aquela possível há poucos anos, quando eram reduzidas as opções de dar-se ao conhecimento, que normalmente ocorria por meio das emissoras de rádios, dadas as dificuldades já expostas em capítulo anterior.

Ao lado disso, tais sítios oferecem ao público em geral espaço para que compartilhem com número indeterminado de pessoas previamente conhecidas entre si ou não, suas preferências musicais, ou propiciando a formação de novos relacionamentos.

A estrutura comum dos vários sítios de relacionamento existentes ${ }^{366}$ consiste na oferta de espaço digital virtual mediante a aceitação de contrato contendo os termos de uso do serviço e da concessão de licença de publicação, em termos globais (devido à natureza da internet), limitada à duração da utilização do serviço. Quase todos os sítios dividem os usuários em duas categorias: os músicos e os fãs (usuários comuns).

No caso dos músicos, os intérpretes (que podem ser também os compositores), utilizando-se do sistema informático oferecido pelo sítio, preenchem o espaço virtual que lhes é concedido com textos contendo informações sobre suas carreiras, fotos, vídeos, obras musicais para audição on-line e, em alguns casos para download, conforme o decididem) e

365 Os sítios de relacionamento possuem, como indica a própria denominação, o objetivo de propiciar relacionamentos interpessoais entre seus usuários, os quais podem se dar sob vários enfoques: interesses musicais, atividades profissionais, hobbies, esportes, relacionamentos afetivos e mesmo o reencontro de antigas e atuais relações de amizade (a exemplo do famosíssimo Orkut, que tantas questões jurídicas tem suscitado em nosso país).

366 São alguns dos sítios de relacionamento existentes, com enfoque na música: Last.fm, ProjectOpus, Jamglue, PureVolume, ReverbNation, MOG, YourSpins, Qloud, iLike, Bandwagon.co.uk, Jamendo, Pandora, Rapspace.tv, uPlayMe, FineTune, MP3.com, MusicHawk, Splice, FIQL (Disponível em: $<\mathrm{http}: / /$ mashable.com/?p=1528>. Acesso em: $1 .^{\circ}$ out. 2007). 
$b \log s^{367}$, além de indicarem meios de contato, podendo ser através da própria internet (e-mail, instant messengers ou formulário de contato) ou por telefone e endereço físico.

Aos usuários, desse modo, é possível a ampla interação com os intérpretes, inclusive externando, de forma eficaz e direta, suas opiniões sobre determinada obra musical ou qualquer outro tema. Por mais que os artistas possuam seus sítios oficiais, a participação em sítios de relacionamento coloca-os lado-a-lado com tantos outros, dos mais variados níveis de sucesso e qualidade musical, tornando-os mais "reais", na concepção dos fãs, os quais têm a possibilidade de compará-los com outros que também utilizem o mesmo serviço, reafirmando sua admiração (ou, ao inverso, repudiando), incluindo em seus próprios espaços virtuais links para as páginas de seus artistas preferidos.

Os modelos de negócios dos sítios de relacionamento com enfoque na música são variados, da mesma maneira que diversas são as formas de receita: alguns dos sítios, a exemplo do mais famoso em nível mundial, o MySpace ${ }^{368}$ Music, oferecem o espaço para interação e não cobram qualquer preço dos artistas ou dos usuários, auferindo receita a partir dos anúncios publicitários inseridos em suas páginas, inclusive naquelas utilizadas pelos músicos.

No Brasil, destaca-se o sítio de relacionamento "Trama Virtual", voltado para o segmento musical independente, o qual oferece aos músicos e aos fãs um bem-planejado

367 "Blog: é uma abreviação de weblog, ou registro eletrônico, e apresenta um caráter dinâmico e de interação possibilitados pela facilidade de acesso e de atualização. O que distingue o blog de um site convencional é a facilidade com que se pode fazer registros para a sua atualização, o que o torna muito mais dinâmico do que os sites pois sua manutenção é mais simples e apoiada pela organização automática das mensagens, ou posts, pelo sistema, que permite que novos textos sejam inseridos sem a dificuldade de atualização de um site tradicional". (BARBOSA, Conceição Aparecida Pereira; SERRANO, Claudia Aparecida. O Blog como ferramenta para construção do conhecimento e aprendizagem colaborativa. Disponível em: $<$ http://www.abed.org.br/congresso2005/por/pdf/011tcc3.pdf $>$. Acesso em: 12 nov. 2007).

368 Acessível por $<$ http://www.myspace.com>. Note-se, entretanto, que no contrato contendo os termos de uso do sítio faz-se constar expressamente que pode haver a cobrança de subscrição pelos serviços prestados: "3. Fees. You acknowledge that MySpace.com reserves the right to charge for the MySpace Services and to change its fees from time to time in its discretion. If MySpace.com terminates your Membership because you have breached the Agreement, you shall not be entitled to the refund of any unused portion of subscription fees". Em 30 de Setembro de 2007 o MySpace tinha o impressionante número de 203.551.172 usuários cadastrados. De acordo com o estudo da IFPI intitulado IFPI:07 Digital Music Report o MySpace foi responsável pela visibilidade que os sítios de relacionamento têm atualmente no mercado da música: "Social networks and user generated content made a major impact on digital entertainment in 2006 and represent an opportunity despite copyright concerns. Social networks have been around for several years, but really came to worldwide attention with the growth of MySpace, famously acquired by News Corporation." (IFPI - International Federation of the Phonographic Industry. IFPI:07 Digital Music Report. Londres: IFPI, 2007. p.12). 
sítio $^{369}$, com interessante método de pagamento de direitos autorais mediante o que fazem denominar "download remunerado", que consiste no patrocínio, por parte de sociedades empresárias interessadas, de valores que determinam e é repartido entre os músicos pelo número de downloads efetuados no sítio divididos proporcionalmente pelo número de downloads de músicas dos artistas.

Outros sítios apresentam modelo financeiro híbrido: oferecem espaço gratuito de divulgação aos intérpretes, com diversas ferramentas tecnológicas à disposição, e então direcionam os interessados em adquirir determinado álbum ou faixa musical a um (ou elencam vários como opção) dos sítios de venda de música digital (os digital music shops), sendo remunerados pela indicação. Assim funciona o sítio MP3.com, dentre outros.

Existe ainda o sítio "Last FM"370, cujo slogan significa, em vernáculo, algo como a "revolução social da música ${ }^{371 ", ~ e ~ s e ~ p r o p o ̃ e ~ a ~ e x e c u t a r ~ o b r a s ~ m u s i c a i s ~ c o m o ~ r a ́ d i o ~ o n-l i n e, ~}$ auxiliar na busca de obras, bandas e estilos musicais, principalmente mediante as indicações e recomendações feitas pelos usuários.

Tal sítio contém um sistema em que o usuário digita o nome de uma música, estilo, nome do artista ou de banda musical, com o que lhe é apresentada uma "rádio" virtual que executa não somente o que foi digitado, mas também músicas, estilos, artistas ou bandas similares. Por exemplo: i) o usuário que pretende escutar Luciano Pavarotti, assim digita seu nome em quadro de pesquisa; ii) o sistema "cria" uma rádio virtual que executa não somente canções do artista, mas de outros similares (Plácido Domingo, Jose Carreras etc.), bem como artistas desconhecidos; iii) na execução são exibidos os títulos

369 Cujos serviços, em resumo, são explicados pelo próprio sítio: "Se você é músico você pode criar uma homepage inteiramente personalizada, disponibilizando informações sobre seu trabalho - release, fotos, MP3, links favoritos, etc. -, além de divulgar os eventos que quiser e outras vantagens. Você pode participar dos charts e entrar em contato com bandas de todo o país. Suas músicas serão analisadas pela comunidade do site, e você ainda corre o risco de ter seu trabalho comentado por artistas e produtores de renome. Oferecemos também um Guia com serviços e informações essenciais para quem faz e gosta de música, e Classificados inteligentes.

Se você é amante da música ficará conhecendo os artistas que fazem parte da novíssima cena independente brasileira. Poderá bancar o crítico musical, avaliando, dando nota e comentando os trabalhos. Além disso, você ainda pode receber por e-mail um Newsletter só com informações do seu interesse e ainda ter acesso às demais áreas do site como Fórum, Classificados, Agenda, etc." (Disponível em: $<$ http://tramavirtual.uol.com.br/>. Acesso em: 14 out. 2007).

370 Tal serviço foi tratado em minúcias no Capítulo 2. Ora a menção se faz relevante em vista de o mesmo não ser somente uma rádio on-line, mas também um sítio de relacionamento, onde os usuários compartilham opiniões e recomendações.

371 "Social music revolution" (Cf. <http://www.last.fm>. Acesso em: 1. out. 2007). 
das faixas musicais, informações de autoria, interpretação e titularidade do fonograma, com a opção de que o usuário adquira o disco em seu formato físico (CD) ou mesmo virtual.

Constata-se, outrossim, a tendência de que na exploração da música on-line por sítios de relacionamento prevaleça a característica híbrida, com diversos serviços sendo oferecidos pelo mesmo sítio, com receitas provenientes tanto de publicidade de terceiros quanto indicações para outros sítios que tornem disponíveis a música para download mediante pagamento ou subscrição ou mesmo com o próprio sítio ofertando-a diretamente.

Algumas questões jurídicas emergem de tal forma de exploração de música online: a) a inclusão (upload) de obra musical, não autorizada pelo titular dos direitos autorais; b) a utilização de perfis falsos (fake profiles); c) a propagação de obras musicais com conteúdo criminoso.

a) $\mathrm{O}$ armazenamento de obra musical digital em sítio de relacionamento, bem como a correspondente execução on-line ou oferecimento ao download pode ser feito à revelia dos direitos autorais, sendo exemplares as seguintes situações: i) o artista que oferece a música à audição ou download não buscou a necessária autorização expressa do compositor ${ }^{372}$ ou do titular dos direitos patrimoniais $^{373}$ da obra musical para que procedesse à interpretação e à fixação, mas mesmo assim a insere no sítio para ser utilizada pelos usuários. Pode, ainda, nesse caso, haver infração aos direitos morais ${ }^{374}$ do compositor se o artista indevidamente se intitular autor ou se modificar a obra, comprometendo sua integridade. Importante apontar, nesse caso, a diferença essencial entre o copyright e o direito de autor continental (adotado pela nossa legislação), já que naquele sistema existe o licenciamento compulsório de obras musicais fixadas (Compulsory Mechanical License for Recordings) ${ }^{375}$, que consiste no

372 Art. 28 e ss. da LDA.

373 O autor, titular originário de direito de autor ou o titular derivado de direito de autor e também de direitos conexos, no campo musical normalmente o produtor fonográfico (art. 93, LDA).

374 Art. 24 e incisos, LDA.

375 De acordo com o exemplo de Steve Gordon, uma vez que os Beatles gravaram e lançaram o disco contendo a música "Yesterday", de John Lennon e Paul McCartney, qualquer outro pode regravar "Yesterday" sem a necessidade de obter o consentimento. "Mechanical Rights. The right to reproduce and distribute to the public a copyrighted musical composition on audio 'phonorecords' such as CDs, tapes, and vinyl is referred to as 'mechanical' right. Compulsory License for Mechanicals. Licenses to 
direito de qualquer um regravar e distribuir, sem a necessidade de autorização pelo titular, obra musical publicamente e anteriormente distribuída sob autorização do titular do copyright, mediante pagamento de royalty determinado pelo CARP - Copyright Arbitration Royalty Panel; ii) O usuário comum que oferece - mesmo sendo fã e com o intuito de homenagear seus artistas preferidos - a partir de sua página no sítio de relacionamento, à audição e (ou) download alheios, sem autorização, obras musicais sob titularidade de terceiros infringe direitos patrimoniais e conexos de autor. Em ambos os casos, para além da infração à lei, também ocorre infração ao contrato contendo os termos de uso dos sítios de relacionamento, os quais demonstram cautela em questões que envolvem direitos autorais ${ }^{376}$ e punem os infratores com o cancelamento da prestação dos serviços.

b) A utilização dos chamados "perfis falsos" (fake profiles) é extremamente comum nos sítios de relacionamento; alguns buscam se fazer passar por terceiros, anônimos ou famosos, nesse caso os artistas, indevidamente incluindo nas páginas obras musicais sem ter autorização para tal. Muitas das vezes tratamse de fãs dos intérpretes que lhes pretendem prestar homenagem, entretanto acabam por infringir os direitos autorais respectivos, além de fazer incidir o

exploit mechanical rights are called mechanical licenses. The Copyright Act contains compulsory licensing provisions governing the making and distribution of phonorecords of musical compositions including songs, although 'dramatic works' such as operas are excluded from the compulsory license. Section 115 of the act provides that once phonorecords of a nondramatic musical work have been publicly distributed in the United States with the copyright owner's consent, anyone else may obtain a 'compulsory' license to make and distribute phonorecords of the work without securing the owner's consent. For instance, once the Beatles recorded and released the record containing the song 'Yesterday' by Lennon and McCartney, anyone else could rerecord 'Yesterday' without having to obtain consent. Anyone may use the compulsory licensing provisions of the Copyright Act to rerecord a previously released song by following the procedures established by the act. Those procedures require giving notice to the owner and paying the statutory royalty for each phonorecord manufactured and distributed. This is called a statutory, or 'compulsory' license because the copyright owner cannot deny permission." (GORDON, The future of the music..., p.5-6)

376 Por exemplo, os termos do contrato do MP3.com: "You are solely responsible for all materials, whether publicly posted or privately transmitted, that you upload, post, e-mail, transmit, or otherwise make available on our sites (Your Content). You certify that you own all intellectual property rights in Your Content. You hereby grant us, our affiliates, and our partners a worldwide, irrevocable, royalty-free, nonexclusive, sublicensable license to use, reproduce, create derivative works of, distribute, publicly perform, publicly display, transfer, transmit, distribute, and publish Your Content and subsequent versions of Your Content for the purposes of (i) displaying Your Content on our sites, (ii) distributing Your Content, either electronically or via other media, to users seeking to download or otherwise acquire it, and/or (iii) storing Your Content in a remote database accessible by end users, for a charge. This license shall apply to the distribution and the storage of Your Content in any form, medium, or technology now known or later developed". 
tipo penal do crime de falsa identidade ${ }^{377}$. No sítio MySpace isso acontece com muita freqüência ${ }^{378}$. O problema maior se dá quando se utilizam tais falsos perfis para cometer crimes contra a honra ${ }^{379}$ ou de ameaça ${ }^{380}$, imaginando-se os agentes escudados por pretenso anonimato possibilitado pela internet (o que em absoluto corresponde à realidade).

c) Outra possibilidade presente nos sítios de relacionamento, daí pelo caráter transnacional da internet, é a propagação de obras musicais com conteúdo que seja lícito em um país, mas, criminoso em outro. Em vista da existência de diferentes regramentos nacionais, são também diversos os níveis de tolerância em relação ao que pode ser considerado em um país o exercício da liberdade de expressão e manifestação artística e em outro ser considerado crime. Nos Estados Unidos, por exemplo, as liberdades civis são levadas a um extremo muito distante do regime de censura que ocorre em um país ditatorial como a China, Cuba ou Irã. Já no Brasil percebe-se a existência de um controle em limites mais severos do que os existentes na Comunidade Européia, por exemplo (e muito mais severo, em conseqüência, do que os limites estadunidenses) $)^{381}$. No ramo do entretenimento musical, são vários os casos e

377 Código Penal: "Art. 307 - Atribuir-se ou atribuir a terceiro falsa identidade para obter vantagem, em proveito próprio ou alheio, ou para causar dano a outrem: Pena - detenção, de três meses a um ano, ou multa, se o fato não constitui elemento de crime mais grave."

378 É o caso, por exemplo, dos cantores e compositores Caetano Veloso e Seu Jorge, os quais têm, respectivamente, três e quatro perfis registrados no $\operatorname{MySpace}$ (e, ao que parece, nenhum verdadeiro) (Disponível em: $<$ http://musicsearch.myspace.com/index.cfm?fuseaction=music.search>. Acesso em: 1 . $^{\circ}$ out. 2007).

379 Calúnia, injúria e difamação, de acordo com os arts. 138, 139 e 140 do Código Penal.

380 Código Penal: "Art. 147 - Ameaçar alguém, por palavra, escrito ou gesto, ou qualquer outro meio simbólico, de causar-lhe mal injusto e grave: Pena - detenção, de um a seis meses, ou multa. Parágrafo único - somente se procede mediante representação."

381 Como exemplo do controle judicial no entretenimento pode ser citada, dentre outras, a recentíssima decisão do Superior Tribunal de Justiça em Ação Civil Pública contra o apresentador de televisão Carlos "Ratinho" Massa, mantendo a decisão de segundo grau que o proibia, assim como emissora de TV, com base no princípio da dignidade da pessoa humana, divulgar confrontos físicos e exibição de deficiências físicas como atrações do quadro de programa televisivo, com propósito sensacionalista.: AGRAVO DE INSTRUMENTO N. ${ }^{\circ} 886.698$ - SP (2007/0087877-4) RELATOR: MINISTRO ANTÔNIO DE PÁDUA RIBEIRO EMENTA "Ação Civil Pública. Exibição de programa televisivo. Proibição. Censura que não se verifica. Atendimento ao princípio da dignidade da pessoa humana. Processual Civil. Embargos de declaração. Omissão, contrariedade ou obscuridade não verificadas. Violação a dispositivos de lei federal. Prequestionamento. Ausência. Súmulas 282 e 356/STF. No mérito, a discussão demanda reexame de fatos eprovas. Incidência da Súmula 7/STJ. Agravo de instrumento desprovido". DJ 21/09/2007. Tal espécie de programa televisivo, entretanto, é extremamente comum nos Estados Unidos. 
alguns exemplos 382 : i) o caso do humorista e cantor cearense "Tiririca" e sua música "Veja os cabelo dela", que foi objeto de ações judiciais. Na esfera penal, o artista acabou absolvido, enquanto na esfera cível a sua gravadora, a Sony Music, foi condenada a pagar $\mathrm{R} \$ 300.000,00$ (trezentos mil reais) ao Fundo de Defesa de Direitos Difusos, por não ter tido a cautela necessária na análise do conteúdo da obra musical da qual é detentora dos direitos patrimoniais ${ }^{383}$; ii) o caso da banda gaúcha "Bidê ou Balde", no qual o Tribunal de Justiça do Rio Grande do Sul entendeu que a música "E por que não?" faz apologia ao

382 No ramo musical do entretenimento também os Estados Unidos apresentam um grande nível de tolerância, a julgar pelo estilo "gangsta rap", onde os compositores e intérpretes defendem bandeiras racistas e antisociais, pugnando pelo extermínio de policiais, entre outros temas que certamente seriam proibidos no Brasil (um exemplo ilustrativo é a música de uma das principais bandas do gênero, que se denomina justamente "Gangsta Rap", chamada "My Mamma..s A Bitch", em vernáculo algo como "Minha Mãe é Vadia"). Para aprofundamento no assunto, vide o sítio da Organização Não-Governamental "Freedom of Musical Expression" (FREEMUSE), acessível por <http://www.freemuse.org/>. Para interessante artigo sobre o tema, vide MARMELSTEIN, George. Um tapinha dói ou não dói? A censura na música após a Constituição de 88 - limites à liberdade de expressão musical. In: Get Up, Stand Up, Stand Up For Your Rights. 12 de Setembro de 2007. Blog acessível por: <http://georgemlima.blogspot.com/2007/09/umtapinha-di-ou-no-di-censura-na-msica.html>. Acesso em: 3 out. 2007.

383 "APELACAO CIVEL 2000.001.16893. Rel. DES. MARIO ROBERT MANNHEIMER - Julgamento: 10/02/2004 - DECIMA SEXTA CAMARA CIVEL. ACAO CIVIL PUBLICA LESAO DO DIREITO A IMAGEM CARACTERIZACAO INTERESSES DIFUSOS OBRIGACAO DE INDENIZAR Ação Civil Pública. Não constitui cerceamento de defesa o julgamento antecipado da lide com indeferimento das provas pericial e testemunhal requeridas pelas partes, por se verificar, diante do conjunto de elementos carreado aos autos, que tais provas não são necessárias à formação da convicção do julgador. O direito à preservação da imagem das diversas etnias que integram nosso país, entre as quais a negra ou afrobrasileira, constitui direito difuso, ensejando o emprego da Ação Civil Pública para coibir sua violação, tendo as associações autoras legitimidade para sua propositura, visto terem sido constituídas há mais de um ano antes do ajuizamento tendo corno objetivos sociais, fundamentalmente, defender os direitos dos cidadãos e enfrentar a discriminação ou o preconceito de raça. Composição musical cuja letra contém expressões altamente ofensivas à mulher de etnia negra, que é retratada de forma pseudo jocosa como feia e cheirando mal. A absolvição do autor da música no juízo criminal, por entenderem os julgadores não estar caracterizado crime de racismo apenado pela Lei n. ${ }^{0} 7.716 / 89$, face à ausência de dolo específico, não impede a propositura em face do produtor fonográfico de Ação Civil Pública com base no artigo $1 .^{\circ} \mathrm{IV}$, da Lei n. ${ }^{\circ} 7.347 / 85$, para a qual não é necessário o dolo, bastando que fique caracterizado o dano ao direito difuso. Culpa da empresa produtora do fonograma que deixou de proceder a uma análise do conteúdo ofensivo da obra ao adquirir os respectivos direito autorais. Valor da indenização a ser fixado no valor aproximado do lucro obtido pela Ré com a venda da obra, devendo ser recolhido ao Fundo de Defesa de Direitos Difusos, criado pela Lei n. ${ }^{\circ}$ 9.008/95 e regulamentado pelo Decreto n. ${ }^{\circ} 1.306 / 94$, na forma preconizada no artigo 13 , da Lei ${ }^{\circ}{ }^{\circ} 7.347 / 85$, para ser utilizado em programas contra o preconceito racial. Ônus sucumbenciais fixados na forma preconizada no parágrafo único do art. 21 do CPC, em vista de ter sido o pedido dos Autores atendido, havendo tão-somente uma redução quantitativa, o que se reflete nos honorários sucumbenciais, fixados em função do valor da condenação. Conhecimento e provimento parcial da apelação". [grifo nosso] 
incesto e à pedofilia e decidiu, de forma pioneira ressaltando o caráter ubíqüo da internet, onde a obra já se encontra disponível, reconhecendo ser "impossível, material e constitucionalmente, a pura e simples extirpação do material do universo social, já entranhada nos lares e à disposição em centenas de 'sites' na Internet" 384 e não tratou de simplesmente proibi-la, com o que, na opinião do relator (e voto vencedor) se eventualmente se alegaria censura "tão marcante em nosso passado próximo, tendo presente que a livre manifestação artística tem substrato constitucional, ainda que discutível quando de cunho atentatório, como na espécie, equalizando garantias constitucionais, em perfeita e efetiva democracia". Para o Desembargador Relator dessa decisão, "a solução, ao meu ver, está em reconhecer, expressa e judicialmente, que a letra da música indicada efetivamente tem conteúdo que estimula e banaliza a violência sexual contra crianças, ao incesto e à pedofilia, objetivando minimizar seus efeitos, com imposição, a partir daí, de penalização que reverta em benefício do público alvo atingido". Assim, foi decidido que os meios de comunicação e divulgação que veicularem a música devem avisar sobre seu conteúdo ${ }^{385}$ e que deverá ser recolhida multa ${ }^{386}$ ao Fundo Estadual de Direitos da Criança e

384 Ementa: "AGRAVO DE INSTRUMENTO. AÇ̃̃O CIVIL PÚBLICA. LETRA DE MÚSICA QUE FAZ APOLOGIA À PEDOFILIA E AO INCESTO. ANTECIPAÇÃO DE TUTELA. POSSIBILIDADE, EM TERMOS. Inegável que a letra da música 'E por que não?', da banda 'Bidê ou Balde', materializa apologia ao incesto e à pedofilia, sendo impossível, material e constitucionalmente, a pura e simples extirpação do material do universo social, já entranhada nos lares e à disposição em centenas de 'sites' na Internet. Hipótese de reconhecimento judicial da ofensa, com minimização de seus efeitos, com aplicação de multa, por veiculação e decorrente de parcela dos lucros, em benefício de órgão estadual de bem estar do menor. Recurso parcialmente provido, por maioria". Agravo de Instrumento 70.013.141.262, 7. ${ }^{\text {a }}$ âmara Cível - TJ/RS, Relator Des. RICARDO RAUPP RUSCHEL.

385 "Desta forma, impõe-se que os meios de comunicação e divulgação, toda vez que a referida composição for veiculada, consignem, expressa e antecipadamente, que a mesma tem conteúdo que estimula e banaliza a violência sexual contra crianças, ao incesto e à pedofilia, assim reconhecida judicialmente, ressalva que deverá constar, expressamente, na capa de eventuais novas produções que a contenham". Agravo de Instrumento 70.013.141.262, 7. ${ }^{\mathrm{a}}$ Câmara Cível - TJ/RS, Relator Des. RICARDO RAUPP RUSCHEL.

386 "Relativamente à comercialização do CD produzido no ano de 2000 ("Se sexo é o que importa, só o Rock é sobre amor"), bem como do DVD da banda "Bidê ou Balde", que contenha a composição indicada, imponho uma multa de $10 \%$ de sua comercialização/ faturamento, a ser recolhida ao Fundo Estadual de Direitos da Criança e do Adolescente, em trinta dias, sob pena de multa de duas vezes o valor apurado em perícia contábil, se necessária.

No que diz respeito ao CD "Acústico MTV Bandas Gaúchas", a multa fica estipulada em 20\% sobre o faturamento da banda da comercialização daí decorrente, tendo em vista que o grupo possui cinco faixas no $\mathrm{CD}$, sendo a composição "E por que não?" uma delas, com recolhimento nos mesmos moldes acima determinados. 
do Adolescente de acordo com os critérios expostos na decisão; iii) o caso da condenação de músico e compositor da banda gaúcha Zurzir por preconceito de raça, em vista de sua conduta (anti)social e comprovada pela letra da música "88 Heil Hitler"387 388.

Com efeito, a cuidadosa análise dos casos em concreto é que fornece os subsídios necessários para a correta prolação de decisão judicial e o atingimento de seu fim colimado: a Justiça. Entretanto, é de fundamental importância que os julgadores tenham muita cautela ao proibir forma de utilização de qualquer obra artística, pois

uma protecção constitucional robusta da liberdade de expressão no seio de uma sociedade democrática não assenta no postulado de que a comunicação é sempre inócua e inofensiva, justificando-se, prima facie, mesmo em casos em que a mesma se reveste de um caráter socialmente provocatório, ofensivo e mesmo danoso. ${ }^{389}$

Toda vez que se faz um juízo estético-repressor contra uma manifestação artística, seja por considerá-la um escárnio, seja por considerá-la uma deseducação, se pratica a mais

No relativo aos shows, onde inserida a canção indicada, deve ser recolhida a multa de $10 \%$ do total da arrecadação, disso dando-se ciência ao promotor do evento, sob pena de multa estabelecida no dobro do valor devido". Agravo de Instrumento 70.013.141.262, 7. ${ }^{\text {a }}$ Câmara Cível - TJ/RS, Relator Des. RICARDO RAUPP RUSCHEL.

387 Ementa: "PRECONCEITO DE RAÇA. ORNAMENTOS. QUE UTILIZA A CRUZ SUÁSTICA. Se de um lado a constituição exaltou a liberdade de pensamento como um dos direitos fundamentais, ficou preservada também a dignidade humana, com repúdio à discriminação ou preconceito. Comprovada conduta preconceituosa, divulgação de música de apologia ao líder nazista, é de ser mantida a condenação. APELO IMPROVIDO". Apelação Crime 70012571659, 5. a Câmara Criminal, TJ/RS, Rel. Desa. GENACÉIA DA SILVA ALBERTON. Ainda, no âmbito do direito penal, existe a negativa do Min. Marco Aurélio, do STF em conceder hábeas corpus, em caso que envolve a música "Bonde do 157", do compositor e intérprete MC Frank (Frank Baptista Ramos), por apologia ao crime (STF: HABEAS CORPUS N. 89244).

388 Para George Marmelstein: "certamente, é fácil concordar com uma decisão como a do Tribunal de Justiça do Rio Grande do Sul, ao condenar a Banda Zurzir, que nitidamente utiliza a música para disseminar idéias preconceituosas de cunho nazista. Letras musicais que elogiam Hitler e defendem o extermínio de judeus certamente não estão protegidas pela liberdade artística. Por outro lado, bem mais difícil é aceitar uma decisão como a do Tribunal de Justiça do Rio de Janeiro que condenou a música 'Veja os cabelos dela', do Tiririca, que, apesar do mau gosto musical, nada mais é do que uma manifestação tosca do típico humor brasileiro (ou pelo menos, do humor cearense). Como meio termo, muito mais complexo é definir se a música 'E por que não?' da banda gaúcha Bidê e Balde deve ser proibida. Ela insinua o incesto e a pedofilia (por sinal, a letra é de extremo mau gosto, embora a melodia seja até legal). Até que ponto a sociedade, em nome da democracia e da liberdade de expressão, deve tolerar esse tipo de manifestação artística? É difícil responder, sobretudo pelo fato de ainda sermos muito imaturos em matéria de liberdade de expressão. Justamente por conta de nossa imaturidade democrática, defendo que, por enquanto, é melhor ousar em favor da liberdade de expressão, podando-se apenas os extremos (como no caso da Banda Zurzir)" (MARMELSTEIN, Um tapinha dói ou não dói?...).

389 CANOTILHO, J. J. Gomes; MACHADO, Jónatas E. M. Machado. 'Reality Shows' e liberdade de programação. Coimbra: Coimbra Editora, 2003. p.15-16 
pura e simples censura. Daí a necessária cautela que o julgador deve ter e considerar a opção de proibir como absoluta exceção à regra. A partir do momento em que se proíbe algo, mais facilmente se dará a próxima proibição, e assim progressivamente, até que os limites sejam reduzidos e, então, a liberdade como valor essencial deixe de existir.

O fato é que na internet é impossível simplesmente proibir, conforme bem ressaltou o relator da decisão do caso da banda "Bidê ou Balde". É o que também demonstra o notório caso do namoro da modelo e apresentadora de televisão Daniela Cicarelli em águas espanholas, que acabou publicado na internet e, mesmo com ordem judicial proibindo sua veiculação em um determinado sítio, o vídeo contendo as imagens era facilmente localizável em diversos outros sítios na grande rede global.

O mesmo vale para a música, com conteúdo lícito ou ilícito. Muito embora as tentativas de vedar o tráfego não-autorizado de conteúdo musical digital tenham sido inúmeras, por parte da indústria fonográfica, o fato é que sempre os usuários e programadores de sistemas acabam por desenvolver novos meios de burlar qualquer aparato tecnológico que venha a ser criado pelos titulares de direitos autorais.

Da mesma forma, obra musical que contenha conteúdo que seja ilícito em determinado país trafega livremente pela internet, adentrando em domínios outros onde seja permitida ou igualmente vedada.

Nesse tema não se deve esperar muitas alterações, em vista das diferenças culturais existentes ao redor do mundo. Por mais que todos os países que façam parte da ONU Organizações das Nações Unidas tenham obrigatoriamente firmado o tratado contendo a Declaração dos Direitos do Homem, o conflito entre os princípios da dignidade da pessoa humana e da liberdade de expressão recebe em cada país tônica própria. E é bom que assim seja, sob pena de uma indesejada uniformização cultural.

Em que pese a flexibilidade verificada em cada país em relação aos direitos humanos e à licitude dos atos de usuários de sítios de relacionamento, é fato que, em termos globais, a indústria fonográfica passou a reconhecer as possibilidades de negócios geradas com os sítios de relacionamento. Desse modo, ao invés de considerá-los mais uma ameaça aos titulares de direitos autorais, passou ao entendimento de que "os sítios de relacionamento são potencialmente uma ótima oportunidade para a indústria musical. Esses sítios alcançam uma enorme comunidade de fãs de música, oferecem novas formas 
de marketing musical e de comercialização de faixas, álbuns e vídeos. Eles também auxiliam a indústria a descobrir novos artistas"390.

Com base nesse enfoque, as gravadoras passaram a firmar contratos de licenciamento $^{391}$ com os principais sítios de relacionamento, de modo que as obras musicais inseridas pelos usuários não infrinjam os direitos autorais dos respectivos titulares ${ }^{392}$, autorizando o armazenamento, a reprodução e a execução on-line de conteúdos digitais, inclusive audiovisual e musical.

\subsubsection{Os Aparelhos de Telefonia Celular}

Uma das principais inovações tecnológicas tornadas acessíveis ao público consumidor no final do século passado foi a possibilidade da utilização das redes de telefonia celular, por meio de aparelhos portáteis que proporcionam mobilidade aos usuários, que com outros se comunicam ${ }^{393}$, "condição, aliás, de caracterizada utilidade", que "além de suprir uma das novas necessidades do ser humano, é fator de progresso nos aspectos sociais, culturais ou econômicos"394.

390 Tradução livre de "Social networking sites are potentially a great opportunity for the music industry. These sites reach a huge community of music fans, offer new ways of marketing music and selling tracks, albums and videos. They also can help the industry discover new artists." (IFPI, IFPI:07 Digital Music..., p.12).

391 LDA, "Art. 49. Os direitos de autor poderão ser total ou parcialmente transferidos a terceiros, por ele ou por seus sucessores, a título universal ou singular, pessoalmente ou por meio de representantes com poderes especiais, por meio de licenciamento, concessão, cessão ou por outros meios admitidos em Direito, obedecidas as seguintes limitações:". [grifo nosso)

392 Notícias dão conta de que na operação de aquisição do sítio de relacionamento Youtube, em setembro de 2006, a então adquirente Google Inc. negociou a cessão de quinhões de participação societária com as principais gravadoras, que de ameaçadoras passaram a ser incentivadoras de tal sítio de relacionamento. $<\mathrm{http}$ ://www.correiodobrasil.com.br/noticia.asp?c=108331>. Acesso em: 7 out. 2007.

393 "Quando se fala em rapidez de comunicação entre as pessoas distantes não se menospreza a telefonia sem fio (celular a celular) como, também, a chamada móvel-fixo ou fixo-móvel". (LOSSO, Atividade empresarial..., p.21).

394 LOSSO, Atividade empresarial..., p.21. Para o autor, que analisa a telefonia celular sob a ótica do direito do desenvolvimento, "o emprego da palavra 'celular' para a denominação da rede partiu do reuso de freqüências de canais pela redução do alcance de ondas eletromagnéticas, emitidas por uma estação ou por terminal de transcepção. Concebeu-se a utilização simultânea da mesma freqüência, por diversos usuários, em uma área de cobertura. Assim, quem portasse um telefone celular portátil, ou que tivesse instalado um equipamento equivalente em sua casa ou escritório poderia se conectar, através do uso de ondas de rádio, com uma estação que a processaria e a transmitiria a um outro telefone ou terminal ou a uma outra Estação Rádio Base até que se realizasse a desejada conexão entre usuários". 
Se há pouco tempo, não mais que 20 anos, a função principal da telefonia celular consistia em meramente conectar a voz de pessoas que estivessem em movimento, atualmente constitui veículo de desenvolvimento ${ }^{395}$ e de qualidade de vida, parte indissociável do cotidiano de grande parcela das pessoas no mundo ${ }^{396}$.

395 Ezequias Losso discorre, em capítulo de sua dissertação de mestrado, que a correlação entre a telefonia celular e "o direito de desenvolvimento se projeta na medida em que os avanços científicos e tecnológicos estão indo quase além do imaginável. Até os dirigentes das grandes potências mundiais mostram-se surpresos com as notícias que circulam dando conta de feitos que, até pouco tempo, estavam no campo da imaginação" (LOSSO, Atividade empresarial..., p.94).

396 Sobre a importância presente e futura do aparelho de telefonia celular no cotidiano das pessoas, Ezequias Losso cita artigo de William Webb, chefe de Pesquisa e Desenvolvimento da Ofcom, agência reguladora de comunicações na Grã-Bretanha, em que se aponta uma situação hipotética de 2025 mas que em grante parte já atualmente está em funcionamento: "Estamos em 2025. Seu telefone celular é agora muito mais do que um dispositivo de comunicação: é mais parecido com um controle remoto da sua vida. Ainda é possível chamar o aparelho de celular, mais por uma questão de hábito. Mas o aparelho é uma agenda, um dispositivo de entretenimento, de pagamento de contas, centro de segurança e muito mais. Em um dia comum, o aparelho começaria a trabalhar antes mesmo de seu dono acordar. O aparelho conhece as rotas que seu dono segue pela cidade, por isso pode informar sobre problemas nas ruas ou com o transporte público e ajustar a hora em que o despertador toca de acordo com a presença ou não destes problemas, além de apresentar a melhor rota para o trabalho. O dispositivo também controla sua casa, reprograma o aquecimento central se o dono tiver que acordar mais cedo e também dá o alarme remoto caso o sistema de segurança da casa seja acionado. $\mathrm{O}$ aparelho também serve para fazer pagamentos: basta colocar o telefone perto de um sensor e será possível, automaticamente, pagar por viagens em transportes públicos ou comprar produtos em lojas.

O telefone celular do futuro também será um centro de entretenimento fora de casa. Além de armazenar todos os arquivos de música do proprietário, como alguns celulares estão começando a armazenar atualmente, o celular do futuro vai trabalhar junto com o sistema de entretenimento doméstico, enquanto seu proprietário dorme, para encontrar a programação de interesse e baixar, como um podcast, para o dono conferir no transporte público ou em um momento livre. O telefone celular do futuro também será inteligente o bastante para, sozinho, descobrir o que fazer com ligações e mensagens que recebe. Pelo fato de conhecer a agenda de seu dono, o telefone vai saber, por exemplo, direcionar chamadas e recados enquanto o dono está em uma reunião, talvez até fornecendo um pequeno resumo com a identidade da pessoa que ligou e do que se tratava a ligação. Com o conhecimento que tem de quase todos os aspectos da vida de seu dono, o celular do futuro poderá ter muitos novos serviços. Por exemplo, um serviço de planejamento de 'boa alimentação' pode enviar sugestões diárias para o jantar baseado em preferências do dono já armazenadas, seleções prévias e os possíveis produtos que estão dentro da geladeira. $\mathrm{O}$ aparelho poderá também trabalhar baixando a conta semanal do supermercado e, então, retirando os produtos que já foram usados em refeições anteriores na semana ou aqueles que já passaram da data de vencimento. Com conhecimentos locais, o celular pode fornecer informações, alertar o usuário que estiver perto da casa de algum amigo ou até mesmo compilar informações sobre a família, para que todos saibam onde toda a família está. Sair de casa sem o celular já não é muito bom atualmente. No futuro, será como sair de casa sem a carteira, chaves, aparelho de mp3 e o celular, tudo de uma vez. E a utilidade que pode ser mais agradável, o celular do futuro pode guiar seu usuário pela vida.

Então, o que essa aparentemente enorme mudança em nosso relacionamento com nossos telefones celulares vai precisar em termos de novas tecnologias ou mais gastos? Na verdade, e surpreendentemente, de pouco. Atualmente existe uma grande rede de cobertura para celulares, com redes de dados de alta velocidade em muitas casas, escritórios e locais de convivência como cafés. Para o sinal do celular, temos tudo o que precisamos. O que precisamos é de melhores aparelhos e mais inteligência. Os aparelhos vão continuar a melhorar, com telas sensíveis ao toque e com mais resolução, reconhecimento de voz que realmente funcione e capacidade muito maior de memória e armazenamento. Dentro destes celulares, e também nas casas e redes de alto alcance, estarão programas cada vez mais inteligentes, capazes de aprender comportamentos, prever necessidades e se integrar com um crescente número de bancos de 
Com efeito, a chamada "convergência de tecnologias", inaugurada no campo musical com o "dois-em-um", é uma tendência que cada vez mais se consolida no cotidiano das pessoas. Atualmente os telefones celulares são verdadeiros computadores portáteis onde se agrupam câmeras de fotografia e vídeo, software de navegação na internet, possibilidade de acesso a e-mails, controle de agenda e compromissos, editor de textos e planilhas e, com a constituição do marco regulatório da televisão digital, a recepção de canais televisivos interativos.

A importância dos aparelhos portáteis de telefonia celular para o mercado da música é enorme, abrindo uma série de possibilidades, conforme relatam David Kusek e Gerd Leonhard ${ }^{397}$ :

\begin{abstract}
Os telefones celulares são agora utilizados para promover artistas e bandas ao redor do mundo. Usando uma combinação de mensagens de texto e transmissão de imagens, os proprietários de telefones celulares recebem informação sobre datas de turnês, lançamento de álbuns, eventos especiais e canções. No Japão e em outros países asiáticos, os telefones celulares já são a maior fonte de entretenimento e de informação, entregando música, notícias, esportes e tudo mais que as pessoas desejam. No Japão, concertos são rotineiramente promovidos via telefones celulares. Fãs podem comprar ingressos e escolher os assentos a partir da tela e teclado de seus telefones celulares. Os telefones são ainda utilizados como catracas, admitindo a entrada do fã no local do evento por meio de um código no telefone celular.
\end{abstract}

Além da utilização como ferramenta de apoio aos agentes do mercado do entretenimento, os aparelhos de telefonia celular possibilitam o contato direto com as obras musicais, utilizando-as por meio: i) dos chamados ringtones, com o download e execução de trechos ou faixas musicais completas para anúncio de chamadas telefônicas; ii) do

dados - incluindo atualizações de informações do sistema de transporte e de lojas, e gradualmente disponibilizando informações em formatos que serão cada vez mais úteis. Não mais que dez anos atrás, o celular era apenas um aparelho para fazer chamadas telefônicas de voz. Atualmente, é também uma câmera, um aparelho de mp3, agenda e dispositivo para enviar mensagens de texto. Este é apenas o começo da evolução que virá nos próximos 20 anos e que vai transformar o telefone celular em nosso companheiro de vida confiável e indispensável". (WEBB, William. Análise: celular do futuro será controle remoto da vida. Disponível em: <http://noticias.uol.com.br/bbc/2007/01/10/ult2363u9035.jhtm>. Acesso em: 7 out. 2007). No mesmo sentido, David Kusek e Gerd Leonhard, para quem "people are more reliant on their cell phones than ever before, and the dependence is growing" (KUSEK e LEONHARD, The future of music..., p.70).

397 Tradução livre de "cell phones are now being used to promote artists and bands around the world. Using a combination of text messaging and picture transportarion, cell phone owners receive information like tour dates, album releases, special events, and songs. In Japan and in other Asian countries, cell phones have become the major source of entertainment and informatio, delivering music, news, sports, and everything else people want. In Japan, concerts are routinely promoted via cell phones. Fans can purchase tickets and select seats from their cell phone screen and keypad. The phones are even used as the ticket machines, admitting the fan into the venue via a code on the cell phone" (KUSEK e LEONHARD, The future of music..., p.71). 
download e posterior audição quando o usuário desejar, como num aparelho leitor portátil de música (digital audio player).

\section{i) Os ringtones}

Num primeiro momento, entretanto, como alternativa de personalização para os tons de chamada - que são acionados quando o aparelho de telefonia celular anuncia que alguém está chamando o seu portador - existiam algumas melodias pré-gravadas que correspondiam a rudimentares seqüências de beeps, as quais foram denominadas ringtones.

Com a evolução tecnológica, passaram a ser oferecidos os chamados ringtones polifônicos, com maior variedade de notas, mas eletronicamente sintetizados a partir da obra original, mas sem igualá-la no quesito qualidade musical.

Atualmente, com o advento dos mastertones ${ }^{398}$ ou truetones se faz possível a inclusão, com alta qualidade, de trechos - ou da íntegra - de obras musicais digitalizadas, para servir de alerta de chamada ao usuário ${ }^{399}$. Assim, com a expressão ringtones tanto se indica o gênero quanto as espécies ringtones (a mais rudimentar), ringtones polifônicos (os sons eletronicamente sintetizados) e os modernos mastertones ou truetones, assim como os recentíssimos ringback tones, que consistem em sons ou músicas audíveis por quem chama o usuário do aparelho celular ${ }^{400}$.

Com efeito, muito embora não sejam poucos aqueles que os consideram tãosomente ruídos irritantes - até mesmo em vista da ausência (ou deficiência) de educação de alguns usuários de aparelhos de telefonia celular, que os deixam ativados em lugares inapropriados - os ringtones representam enorme mercado para o segmento musical.

398 "Mastertones are the original sound recordings, generally in na MP3 format. Their use, of course, requires the permission of the owners of sound recordings, generally the record companies, as well as the owners of the copyrights of the songs." (GORDON, The future of the music..., p.77). Consta do sítio internet mantido pelo Dicionário Oxford que "Mastertones (also known as true tones, realtones, or ringtunes) are a more sophisticated type of ringtone: instead of a tinny-sounding electronic warble, they're actually digital clips of real music, so every time your phone rings those surrounding you are treated to the latest Destiny's Child or Coldplay single". Disponível em: <http:/www.askoxford.com/ worldofwords/bubblingunder/archive/bubbling_06/>. Acesso em: 7 out. 2007).

399 De acordo com o relatório da IFPI sobre música digital: "ringtones were the first mass market mobile music product to offer phone personalization to music fans. Consumers are now moving away from traditional ringtones to mastertones/real or true tones - ringtones that feature the original sound recording and full track downloads to mobile" (IFPI, IFPI:07 Digital Music..., p.10).

400 "Ringback tones exemplify the varied new uses of music via digital channels. Ringback tones are songs a caller hears while waiting for their call to be picked up." (IFPI, IFPI:07 Digital Music..., p.10). 
De acordo com o estudo "Mobile Entertainment", da consultoria Informa Telecoms \& Media, em 2010 o segmento de conteúdo para telefones celulares deverá movimentar mundialmente a quantia de US\$ 42,8 bilhões, sendo que ao segmento musical corresponderá a fatia de U\$ 11 bilhões ${ }^{401}$ e dessa quantia U\$ 6,8 bilhões deverão ser destinados ao comércio de mastertones ${ }^{402}$.

Ainda, estudo da IFPI indica que no Brasil mais de 90 por cento de todas as vendas de música digital são feitas por meio de downloads via aparelhos de telefonia celular, a maioria deles mastertones ${ }^{403}$.

Tal cenário faz empolgar os titulares de direitos autorais, até mesmo porque, em se tratando de telefonia celular, o controle das obras musicais se dá de forma muito mais simples, uma vez que os ringtones são oferecidos para download no próprio aparelho, sendo que a operadora de telefonia celular pode bloquear a funcionalidade para que os arquivos sejam inseridos por outra forma como, por exemplo, a partir do computador para o terminal móvel.

Assim sendo, o mercado de ringtones se revela muito interessante tanto para os titulares de direitos autorais quanto para a operadora de telefonia celular, já que a respectiva cobrança é efetuada pela mesma forma de pagamento que o usuário adota para adimplir seus débitos com a empresa de telefonia, o que acaba por fazer com que os adolescentes, que não têm acesso a cartões de crédito, sejam os principais usuários desse serviço ${ }^{404}$.

Nesse sentido, o relatório da IFPI de 2007 sobre música digital revela a constatação de que "a música para telefones celulares é auxiliada pela compra por impulso e por uma

401 Cf. FOLHA ONLINE. Conteúdo para celulares deve movimentar US\$ 43 bi em 2010. publicado em 1. ${ }^{\circ}$ de ago. 2005. Disponível em: <http://www1.folha.uol.com.br/folha/informatica/ult124u18754.shtml>. Acesso em: 7 out. 2007.

402 "With Informa Telecoms and Media projecting a \$6.8 billion mastertone business by 2010, labels are salivating over profit and promotional opportunities". (GUNDERSEN, Edna. Mastertones ring up profits. USA TODAY, McLean, 29 nov. 2006. Disponível em: <http://www.usatoday.com/life/music/ news/2006-11-28-mastertones-main_x.htm>. Acesso em: 7 out. 2007).

403 IFPI, IFPI:07 Digital Music..., p.7.

404 "Mobile music benefits from the fact that mobile music services have payments integrated with consumers' mobile bills. This helps particularly among the younger demographic, where credit card ownership is limited." (IFPI, IFPI:07 Digital Music..., p.10). 
bem-estabelecida infraestrutura de pagamento"405. Tal compra por impulso justifica o que constatam Davik Kusek e Gerd Leonhard: "mais interessante é o fato que as pessoas parecem dispostas a pagar valores muito maiores por um trecho de música de dez segundos do que elas pagariam para baixar uma faixa musical inteira"406.

No Brasil, todas as operadoras de telefonia celular atualmente exploram tal importante segmento e oferecem ringtones variados a seus usuários, além de algumas terem desenvolvido sítios específicos contendo promoções e interatividade, pelas quais convidam os usuários a contribuir com suas próprias criações, com o que concedem premiações e descontos nas tarifas de uso dos terminais telefônicos móveis ${ }^{407}$.

A conformação dos interesses em jogo na comercialização de ringtones, porém, pode não ser simples, em vista dos diversos sujeitos envolvidos, cada qual visando ao seu proveito econômico. Em decorrência disso, alguns questionamentos jurídicos passam a surgir.

Em relação ao primeiro e principal destinatário das normas de proteção aos direitos autorais, o autor (no caso da música o compositor): em vista da novidade que constitui a utilização da obra musical por meio dos ringtones, nos contratos que firmaram com o produtor e (ou) editor não consta expressamente a autorização da exploração da criação por tal forma, de modo que o tão-comum alargamento interpretativo dos termos do contrato que por esses é efetuado revela-se contra legem, já que a LDA prevê a independência das diversas modalidades de utilização da obra autoral ${ }^{408}$, bem como o princípio da interpretação restritiva dos negócios jurídicos sobre os direitos autorais ${ }^{409}$.

Não bastassem as previsões legais acima, não socorre ao produtor de fonogramas o argumento de que, ao autorizar a utilização ou diretamente explorar o segmento dos ringtones de que estaria respaldado pelo exercício legítimo dos direitos conexos conferidos

405 "Mobile music is helped by impulse buying and a well-established payment infrastructure." (IFPI, IFPI:07 Digital Music..., p.10).

406 Tradução livre de "more interesting is the fact that people seem willing to pay a lot more money for a ten-second sound sample than they would to download an entire track" (KUSEK e LEONHARD, The future of music..., p.70).

407 São exemplos o Claro Idéias (http://www.claroideias.com.br) e o TIM Studio (http://www.timstudio.com.br).

408 LDA, "Art. 31. As diversas modalidades de utilização de obras literárias, artísticas ou científicas ou de fonogramas são independentes entre si, e a autorização concedida pelo autor, ou pelo produtor, respectivamente, não se estende a quaisquer das demais."

409 LDA, "Art. 4. ${ }^{\circ}$ Interpretam-se restritivamente os negócios jurídicos sobre os direitos autorais". 
pelo art. 93 da LDA $^{410}$ - mormente aquele do inciso V, que trata da autorização ou proibição de "quaisquer outras modalidades de utilização, existentes ou que venham a ser inventadas" - em vista das disposições preliminares que contêm os princípios de aplicação dos direitos conexos, expostas no art. 89 da LDA. Tal artigo, em seu parágrafo único, preceitua a supremacia dos direitos do autor sobre aqueles dos titulares de direitos conexos ${ }^{411}$ e, ainda, no momento da provável cessão de direitos não existia a forma de utilização por meio dos ringtones ${ }^{412}$.

Conforme já visto anteriormente neste estudo, tal inovadora construção contida na Lei de 1998 foi efetuada em decorrência da evolução tecnológica, mais especificamente em vista do caso concreto dos relançamentos das obras musicais do "catálogo" das gravadoras para o então novel meio físico "CD", que a tanta controvérsia deu causa, por meio de decisões judiciais dissonantes, muitas em detrimento aos interesses do autor.

Assim, uma vez autorizada a utilização por meio de ringtones pelo compositor, quem for incumbido a prestar tal exploração (que pode, também, ser cessionário de tal direito), irá, por sua vez, firmar contratos de licenciamento com os diversos agentes especializados na distribuição de música (e ringtones) pela internet ou mesmo pelas operadoras de telefonia celular, os quais, via-de-regra, inserem cláusulas que obrigam a inclusão de mecanismos tecnológicos de proteção aos direitos autorais (DRM's).

Já sobre a relação entre produtor e intérprete pode-se entender, a exemplo da conclusão havida quando da análise dos relançamentos de obras musicais "em catálogo"

410 LDA, "Art. 93. O produtor de fonogramas tem o direito exclusivo de, a título oneroso ou gratuito, autorizar-lhes ou proibir-lhes:

I - a reprodução direta ou indireta, total ou parcial;

II - a distribuição por meio da venda ou locação de exemplares da reprodução;

III - a comunicação ao público por meio da execução pública, inclusive pela radiodifusão;

IV - (VETADO)

V - quaisquer outras modalidades de utilização, existentes ou que venham a ser inventadas."

411 LDA "Art. 89. As normas relativas aos direitos de autor aplicam-se, no que couber, aos direitos dos artistas intérpretes ou executantes, dos produtores fonográficos e das empresas de radiodifusão.

Parágrafo único. A proteção desta Lei aos direitos previstos neste artigo deixa intactas e não afeta as garantias asseguradas aos autores das obras literárias, artísticas ou científicas."

412 LDA "Art. 49. Os direitos de autor poderão ser total ou parcialmente transferidos a terceiros, por ele ou por seus sucessores, a título universal ou singular, pessoalmente ou por meio de representantes com poderes especiais, por meio de licenciamento, concessão, cessão ou por outros meios admitidos em Direito, obedecidas as seguintes limitações:

V - a cessão só se operará para modalidades de utilização já existentes à data do contrato;". 
para o CD, que se trata de lacuna a ser colmatada pelos tribunais em solução de casos em concreto.

Os sujeitos envolvidos, então, na exploração do segmento dos ringtones são, em resumo: o compositor, os intérpretes, os produtores e (ou) editores, os distribuidores, as prestadoras de serviços de telefonia móvel celular e o usuário.

Outrossim, notícias dão conta de que o Ecad (Escritório Central de Arrecadação e Distribuição), "uma sociedade civil, de natureza privada, instituída pela Lei Federal n. ${ }^{\circ}$ 5.988/73 e mantida pela atual Lei de Direitos Autorais brasileira - 9.610/98"413, organismo que, por força da LDA incumbe recolher e distribuir os direitos relativos à execução pública das obras musicais e lítero-musicais e de fonogramas ${ }^{414}$, pretende instituir a cobrança de direitos autorais de execução incidentes sobre os ringtones, por entender "ser devido o direito autoral por exibição pública sobre os ringtones e truetones por sua utilização no momento do toque dos celulares e pela disponibilização de menu de degustação dos toques musicais para compra no site da operadora celular na Internet"415, imiscuindo-se, assim, em setor que não é de sua alçada ${ }^{416}$.

413 Cf. sítio da entidade, disponível em: <http://www.ecad.org.br/ViewController/publico/conteudo. aspx? $\operatorname{codigo}=16>$. Acesso em: 8 out. 2007.

414 LDA "Art. 99. As associações manterão um único escritório central para a arrecadação e distribuição, em comum, dos direitos relativos à execução pública das obras musicais e lítero-musicais e de fonogramas, inclusive por meio da radiodifusão e transmissão por qualquer modalidade, e da exibição de obras audiovisuais."

415 Informa o sítio da ACEL - Associação Nacional de Operadoras Celulares que "Em março de 2004 o Escritório Central de Arrecadação e Distribuição (Ecad) entendeu ser devido o direito autoral por exibição pública sobre os ringtones e truetones por sua utilização no momento do toque dos celulares e pela disponibilização de menu de degustação dos toques musicais para compra no site da operadora celular na Internet, fixando percentuais de pagamento de $7,5 \%$ para os truetones e $5 \%$ para os ringtones, sobre o número mensal total de downloads e de exposição na Internet de cada modalidade." (ACEL - Associação Nacional de Operadoras Celulares. Acel avalia cobrança de direito autoral sobre toques telefônicos musicais. 5 abr. 2005. Disponível em: <http://www.acel.org.br/003/00301009.asp?ttCD_CHAVE=7383>. Acesso em: 8 out. 2007). No mesmo sentido, matéria jornalística de TEIXEIRA, Fernando. Novas tecnologias são novo alvo de cobrança do Ecad. Valor Econômico, São Paulo, 22 ago. 2007, Caderno Legislação \& Tributos.

416 Na busca em dar respaldo jurídico a tal pretensão, a advogada e superintendente do Ecad, Glória Braga, escreveu artigo no qual defende a inexistência de conflito entre novas tecnologias e direito autoral e tenta ampliar a legitimidade da entidade para também alcançar os ringtones e os sítios que promovem a distribuição de obras musicais pela internet, sob a justificativa de que no ato de transmissão que defende haver está presente o direito de execução pública musical: "na internet ou em qualquer meio digital, qualquer utilização de música, independente de sua finalidade (venda de músicas, rádios virtuais etc.), se dá por meio de transmissões. Aí está presente o direito de execução pública musical. E nesse caso, não se diga, que a música necessariamente precise ser ouvida, mas ela precisa apenas ser o conteúdo dessas transmissões. Ora, façamos uma correlação com o que ocorre com a radiodifusão: quando uma emissora 
Diz-se isso em virtude de não se vislumbrar a possibilidade de que o ato de se utilizar ringtones caracterize qualquer execução pública em conformidade com o art. 68, $\S 2 .^{\circ}$ e $3 .^{0417}$, sendo indevida a defesa de que tons do aparelho celular de uma pessoa que é chamada em lugar público poderiam ser considerados como tal. Configura-se, obviamente, a execução privada.

Do mesmo modo, a "disponibilização de menu de degustação dos toques musicais para compra no site da operadora celular na Internet" não se configura apta a ensejar qualquer cobrança pelo Ecad, em vista da expressa limitação contida no art. 46, V da LDA, que não considera ofensa aos direitos autorais a utilização de obras artísticas para fins de demonstração à clientela ${ }^{418}$.

de rádio transmite sua programação, e lá estão inseridas composições musicais, a emissora é responsável por obter a necessária autorização dos titulares de direitos sobre essas criações para radiodifundí-las. O mesmo ocorre com aquele que transmite obras musicais via Internet". (BRAGA, Glória. Propriedade intelectual: não há conflito entre novas tecnologias e direito autoral. Revista Consultor Jurídico, 5 jul. 2005. Disponível em: <http://conjur.estadao.com.br/static/text/36033,1>. Acesso em: 8 out. 2007). Seus argumentos são expostos em sintonia com aqueles das PROs (Performing rights organizations) estadunidenses, segundo a lição de Steve Gordon: "The PROs take the position that ringtones are public performance. This position is justified by the definition of Public Performance in the Copyright Act, reading in relevant part that to perform a work 'publicly' means: ... to transmit or otherwise communicate a performance or display of the work to a place specified by clause (1) or to the public, by means of any device or process, wheter the members of the public capable orf receiving the performance or display receive it in the same place or in separate places and at the same time or at different times. ASAP, BMI and SESAC all offer licenses specifically for ringtone services. Ringtone providers can secure a blanket license just as background music services such as Muzak do. The licenses are based on a small percentage of the revenue, justa as most of the other licenses offered by the PROs". (GORDON, The future of the music..., p.78).

417 LDA, "Art. 68. Sem prévia e expressa autorização do autor ou titular, não poderão ser utilizadas obras teatrais, composições musicais ou lítero-musicais e fonogramas, em representações e execuções públicas. $\S 2 .^{\circ}$ Considera-se execução pública a utilização de composições musicais ou lítero-musicais, mediante a participação de artistas, remunerados ou não, ou a utilização de fonogramas e obras audiovisuais, em locais de freqüência coletiva, por quaisquer processos, inclusive a radiodifusão ou transmissão por qualquer modalidade, e a exibição cinematográfica.

$\S 3 .^{\circ}$ Consideram-se locais de freqüência coletiva os teatros, cinemas, salões de baile ou concertos, boates, bares, clubes ou associações de qualquer natureza, lojas, estabelecimentos comerciais e industriais, estádios, circos, feiras, restaurantes, hotéis, motéis, clínicas, hospitais, órgãos públicos da administração direta ou indireta, fundacionais e estatais, meios de transporte de passageiros terrestre, marítimo, fluvial ou aéreo, ou onde quer que se representem, executem ou transmitam obras literárias, artísticas ou científicas."

418 No mesmo sentido, Dirceu Pereira de Santa Rosa: "e o segundo argumento envolve às restrições existentes para a degustação de ringtones e truetones via Internet. Afinal, a própria Lei 9.610/98 define, em seu artigo $46, \mathrm{~V}$, que não constitui ofensa aos direitos autorais a utilização fonogramas em estabelecimentos comerciais (aqui os sites das operadoras), exclusivamente para demonstração à clientela, bastando que referidos estabelecimentos comercializem, direta ou indiretamente, os suportes ou equipamentos que permitam a sua utilização" (ROSA, Dirceu Pereira de Santa. Download musical: falta definição de direitos autorais dos toques de celular. Revista Consultor Jurídico, 24 jun. 2005. Disponível em: $<$ http://conjur.estadao.com.br/static/text/35778,1>. Acesso em: 8 out. 2007) e o teor da resposta da Acel ao Ecad, conforme notícia publicada no sítio daquela: "Em resposta enviada ao Ecad, que em março 
ii) Outra prática que cada vez está mais corrente é o download de obra musical ou fonograma com fins de posterior audição através do telefone celular. Confirmando a a previsão que o fundador e principal acionista da Microsoft Bill Gates já fazia em 2005, em entrevista a jornal alemão, de que "se você me perguntasse qual aparelho móvel será o preferido para ouvir música, eu com certeza apostaria no telefone celular"419, foi recentemente lançado, com grande estardalhaço na mídia, o aparelho telefônico celular da Apple denominado iPhone, o qual apresenta design futurístico e oferece boa capacidade de armazenamento de músicas e, principalmente, conectividade direta à loja virtual de música iTunes.

As principais fabricantes de aparelhos celulares também lançaram seus modelos que possibilitam o armazenamento e a audição de grande número de obras musicais, as quais são carregadas nos aparelhos a partir do computador pessoal do usuário, acesso a sítios especializados de distribuição de música ou via operadora de telefonia celular.

Diante desse cenário de convergência é que se percebe que a música cumpre, cada vez mais, o papel de protagonista no cotidiano das pessoas, com o que os autores podem efetivamente se beneficiar.

formalizou seu interesse de cobrar das operadoras celulares o direito autoral de exibição pública, a Acel, baseada em parecer contratado junto a renomada especialista em direito autoral, afirmou que o toque do celular representa o uso privado do assinante do telefone e a disponibilização do menu de ringtones e truetones na Internet é uma modalidade de demonstração do produto à clientela, isenta do pagamento de direito autoral pela Lei 9.610/98. Considerando estes critérios, a Acel firmou sua posição no sentido de que não há incidência do direito de exibição pública, previsto no artigo 68 da Lei 9.610/98, sobre os toques telefônicos musicais. 'É importante esclarecer, também, que a atribuição de responsabilidade pelo pagamento do direito, seja às operadoras celulares ou aos desenvolvedores de conteúdo, não encontra amparo na legislação vigente', disse Amadeu Castro, Presidente Executivo da entidade. Na avaliação da Acel apenas incidem, no caso dos ringtones, os direitos autorais de edição, controlados no Brasil pelas editoras musicais. Já para os truetones, além dos editoriais, incidem os fonomecânicos de produtor e de intérprete. A obrigação de pagamento destes direitos é dos desenvolvedores de conteúdo. 'As operadoras celulares respeitam o autor brasileiro e têm previsto em seus contratos com os desenvolvedores de conteúdo cláusulas que garantam o pagamento dos direitos autorais, devidos conforme a lei', afirmou o presidente da Acel ao Ecad". (ACEL, Acel avalia cobrança...).

419 "Bill Gates não anda botando muita fé na continuidade do sucesso dos iPods. Os celulares com tocadores digitais integrados deverão tomar o lugar do aparelho da Apple, cuja popularidade seria 'insustentável', disse ele ao jornal alemão Frankfurter Allgemeine Zeitung. A aposta não é só de Gates. A Nokia, por exemplo, anunciou recentemente um novo aparelho celular capaz de tocar arquivos de áudio com um microdrive de $4 \mathrm{~GB}$, além de uma autonomia de bateria para 12 horas de música. Na última terça-feira, a Microsoft liberou também uma nova versão do Windows Mobile, destinado a PDAs e telefones celulares. Entre as novidades, está o Windows Media Player 10 Mobile. 'Se você me perguntasse qual aparelho móvel será o preferido para ouvir música, eu com certeza apostaria no telefone celular', disse Gates ao jornal alemão. Mas por enquanto o iPod segue forte em seu reinado. Estima-se que dois terços do mercado mundial de tocadores digitais portáteis pertençam ao aparelho da Apple, que vendeu 5 milhões de unidades nos últimos três meses." (CHERNIJ, Carlos. Bill Gates aposta que celular vai substituir iPod. Info Online, São Paulo, 12 maio 2005. Disponível em: <http://info.abril.com.br/aberto/infonews/052005/12052005-6.shl>. Acesso em: 8 out. 2007). 


\title{
3.1.3 Podcasts, Rádios On-Line e Jogos Eletrônicos
}

Não por acaso a Comunidade Européia denomina questões que envolvem a internet como afeitas à "sociedade da informação"420, posto ser na informação digitalizada que a grande rede se baseia.

A questão é como ter acesso à informação desejada, em meio à enorme quantidade de dados disponíveis. No caso da música, diversos milhões de obras musicais encontram-se espalhadas pelos computadores do mundo afora, o que demanda a utilização de meios hábeis a auxiliar o usuário na identificação tanto de obras já conhecidas como de outras novas as quais não conhecem, bem como novos estilos musicais, compositores e intérpretes.

Daí a importância das rádios on-line, das quais o usuário pode selecionar aquelas que ofereçam estilos musicais que sejam de seu agrado. Para David Kusek e Gerd Leonhard ${ }^{421}$ :

\begin{abstract}
A rádio pela internet é uma ótima maneira de expor e associar novas músicas a determinados estilos, artistas parecidos e formadores de opinião. Os programadores musicais dessas rádios pela internet proporcionam uma crescente variedade de novas músicas das gravadoras independentes e de artistas individuais, assim como de todas as majors. Essa fonte de programação de conteúdo é um ótimo filão a ser desenvolvido pelos "marqueteiros" da música e pode proporcionar exposição para seus artistas em um ambiente que dá suporte à descoberta criativa e gostos variados.
\end{abstract}

As rádios on-line já foram objeto de análise no capítulo segundo desta tese e constituem importante tendência no segmento musical. Podem ser dos mais variados tamanhos. Um usuário pode criar a sua "rádio", com as ferramentas tecnológicas disponíveis na internet.

420 Consta do sítio oficial da Comunidade Européia a breve explicação para a sociedade da informação: "Um fenómeno raro há 15 anos, os telemóveis são hoje omnipresentes. A Internet proporciona fluxos intermináveis de informação em linha. À medida que os sistemas digitais de alta capacidade aproximam os mundos, outrora separados, da radiodifusão e das telecomunicações, passamos a ter ao nosso dispor uma quantidade assombrosa de programas e serviços. Esta revolução no domínio das tecnologias da informação está a criar a sociedade da informação: em casa, na escola e no trabalho. A União Europeia, com as suas políticas e acções, guiou e apoiou esta revolução desde o início." (Disponível em: $<$ http://europa.eu/pol/infso/overview_pt.htm>. Acesso em: 13 nov. 2007).

421 Tradução livre de "Internet radio is a terrific way for new music to get exposed and associated with particular genres, related artists, and tastemakers. Music programmers at these Internet radio stations serve up an increasingly wide variety of new music from indie labels and individual artists, as well as by all of the majors. This source of content programming is a great vein for music marketers to tap and can provide exposure for their artists in an environment that supports creative discovery and diverse tastes". (KUSEK e LEONHARD, The future of music..., p.62). 
A grande - e recentíssima - novidade fica por conta do chamado podcasting ${ }^{422}$, que consiste, em termos leigos, num programa de rádio ao qual o usuário se inscreve e, quando um novo programa é publicado, automaticamente é enviado ao assinante, por meio de software que possibilita tal funcionamento, a exemplo do iTunes. Uma vez recebido, o arquivo digital pode ser escutado no computador, telefone celular ou digital audio player na hora em que o usuário desejar.

São diversos os tipos de podcasts, desde aqueles que contêm músicas até alguns de cunho acadêmico e profissional. Trata-se, certamente, de algo revolucionário e que cada vez mais será utilizado.

Sob o prisma jurídico, a inclusão de obra musical ou fonograma no podcast deve ser precedida da necessária autorização do titular ${ }^{423}$, o que no Brasil se faz mediante o contato com a editora musical ${ }^{424}$ e o respectivo pagamento de valor correspondente. A princípio não há que se falar na possibilidade de recolhimento de valores a título de retribuição por execução pública, já que via de regra quem irá utilizar o podcast é o usuário final, por meio de seu computador pessoal ou de seu digital audio player, de modo que se aplica o conceito de execução privada, não ensejando, sob esse motivo, qualquer recolhimento a autor ou escritório de arrecadação de direitos que o represente.

Outrossim, o conteúdo do podcast pode ser executado em local - e para - público, o que enseja a cobrança do correspondentes direitos de execução pública pelo ECAD, ex vi do art. 99 da LDA, inclusive pelo fato de que se deram por transmissão por via internet. Ressalte-se que, nesse caso, de qualquer forma o responsável pela execução pública já teria que prestar o recolhimento, independentemente do meio utilizado e (ou) pelo qual a obra

422 O termo podcast foi cunhado em função do digital audio player iPod. Entusiastas dessa forma de utilização de obras musicais, David Kusek e Gerd Leonhard assim versam sobre o tema: "Perhaps even more interesting is the Podcasting phenomenon, for which we have the former MTV VJ Adam Curry to thank. A Podcast is a very clever way to deliver MP3 audio via the 'Net as a simple subscription feed that can be automatically delivered to iTunes and your iPod, or other MP3 players for listening whenever you want. Podcasting began in mid 2004 and will have spread like wildfire by the time you read this. Like text-based news that can be aggregated in an RSS news reader, Podcasts deliver personalized radio at little or no cost to either the Podcasters or the listeners. Podcasting is pirate radio for the twenty-first century, and will have as profound an effect on traditional radio as blogging has had on publishing." (KUSEK e LEONHARD, The future of music..., p.62). [grifo nosso].

423 LDA, arts. 28, 29 e incisos.

424 LDA, art. 53. 
musical ou fonograma chegou a si ou a seu estabelecimento (p.ex. a utilização de um CD ou de sintonia em emissora de rádio).

De acordo com reportagem publicada no jornal Folha de S. Paulo ${ }^{425}$, o ECAD entende que há a necessidade de dupla autorização para o podcast, uma referente à transmissão, de sua responsabilidade, e outra diretamente dos titulares:

Segundo Márcio Massano, coordenador estratégico de arrecadação do Ecad (Escritório Central de Arrecadação e Distribuição), os internautas precisam de autorização da editora e gravadora de música para inserir músicas em seus programas digitais. Além disso, também devem obter junto ao Ecad a licença para divulgar estes arquivos via internet --o não-cumprimento das determinações acarreta multas.

Ora, tal orientação é baseada numa interpretação similar à que a superintendentegeral do ECAD faz para a utilização de música por meio de telefones celulares, já exposta em nota de rodapé n. ${ }^{\circ} 416$, no sentido de que a transmissão de conteúdo musical, por si só, dá azo à cobrança por tal organização, em vista do art. 99 da LDA:

As associações manterão um único escritório central para a arrecadação e distribuição, em comum, dos direitos relativos à execução pública das obras musicais e lítero-musicais e de fonogramas, inclusive por meio da radiodifusão e transmissão por qualquer modalidade, e da exibição de obras audiovisuais. [grifo nosso]

Entretanto, a tônica desse artigo é explicitar o objeto da associação - no caso o ECAD - de fazer a arrecadação e distribuição dos direitos relativos à execução pública das obras e fonogramas e, para o atingimento desse escopo específico e tão-somente na ocorrência dele, inclui a radiodifusão e a transmissão por qualquer modalidade. A expressão "inclusive por meio" faz tal indicativo.

A truncada redação fica mais clara quando se lê a continuação do artigo extraindo-se a radiodifusão e a transmissão: "(...) à execução pública das obras musicais e lítero-musicais e de fonogramas, inclusive por meio (...) da exibição de obras audiovisuais". Assim se demonstra o equívoco na interpretação do ECAD. A exibição de obras audiovisuais, por si só, não

425 CARPANEZ, Juliana. Podcasts trazem novos desafios à indústria fonográfica. Folha Online, São Paulo, 20 fev. 2006. Disponível em: <http:/www.folha.uol.com.br/folha/informatica/ult124u19676.shtml>. Acesso em: 14 nov. 2007. 
representa sua competência em arrecadar. Há que ser em público, como num cinema. $\mathrm{O}$ fato de o usuário adquirir ou locar um DVD e assisti-lo em sua casa não enseja qualquer pretensão a tal escritório, já que é tema exclusivo dos titulares e não se trata de execução pública.

Diante disso e noutras palavras, não é a mera transmissão de dados de um podcast contendo música digital que validaria tal intervenção arrecadatória do ECAD, já que, para isso, aquele ato deve ser praticado dentro do contexto de execução pública e não quando se encerra em si mesmo, ao contrário do entendimento do órgão.

Com efeito, nesse aspecto a Lei deve ser alterada para solucionar tal questão, mediante a explicitação de que a expressão "transmissão por qualquer modalidade" deve ser interpretada no sentido de que somente quando vinculada à execução pública e não quando se encerra em si mesma ou quando objetiva execução privada. Isso certamente poupará o Poder Judiciário de ser acionado e o risco de haver decisões tiradas de forma errônea, visto a ausência de operadores do direito especializados no direito autoral, podendo vir a prevalecer a versão do ECAD, que conta com bons advogados a defender seus pontos de vista sobre temas que não estão devidamente esclarecidos na Lei.

Já o segmento dos jogos eletrônicos desenvolvidos para utilização nos computadores pessoais e nos consoles é de relevante significância para a música. Tanto músicas já existentes quanto compostas especialmente para o jogo, executadas por grupos musicais reconhecidos ou desconhecidos do grande público, são inseridas nos chamados vídeo games.

A música para jogos eletrônicos movimenta cifras na ordem de bilhões de dólares ${ }^{426}$, sendo curiosíssimo observar que ela inaugurou uma nova fonte de renda para os musicistas clássicos $^{427}$, componentes de estilo musical que justamente pelo desinteresse dos jovens e crianças passou por forte crise nas últimas décadas, com as principais gravadoras especializadas

426 Informam David Kusek e Gerd Leonhard que "the video game industry generated \$28 billion in revenue in 2002 and is arguably one of the most significant sources of entertainment today" (KUSEK e LEONHARD, The future of music..., p.69).

427 Cf. reportagem de Rodrigo Martins, que dá conta de os músicos e compositores de músicas para vídeo games Jack Wall e Tommy Tallarico criaram o evento denominado "Vídeo Game Live" e excursionam pelo mundo com repertório retirado de jogos eletrônicos e, em cada lugar que se apresentam o fazem com a orquestra sinfônica local. (MARTINS, Rodrigo. Vídeo Game 'In Concert'. O Estado de S. Paulo, São Paulo, 27 ago. 2007, Caderno Link. Disponível em: <http://www.link.estadao.com.br/index.cfm?id_conteudo=11687>. Acesso em: 16 nov. 2007). 
do gênero tendo encerrado suas atividades. A receita das vendas de cópias de um jogo de sucesso pode rivalizar com o bom resultado financeiro de um filme da melhor categoria ${ }^{428}$.

São usuários de jogos eletrônicos pessoas de todas as idades, mas é certo que diante da necessidade de se dispor de tempo livre para a atividade as crianças e os adolescentes constituem o público-alvo. O relatório da IFPI sobre os dados da indústria fonográfica no ano de 2007 indica que 48\% das crianças entre 6 e 11 anos participaram de jogos on-line ${ }^{429}$, constituindo a principal atividade exercida na internet por essa faixa etária.

Constata-se, a partir desses dados, que desde muito cedo o usuário trava contato com a música. Se anos atrás as crianças passavam o tempo entretidas em atividades ao arlivre, gastando energia com esportes e atividades lúdicas, atualmente passam horas em frente ao computador ou ao aparelho de televisão jogando jogos eletrônicos, on-line ou não.

Sem adentrar no mérito dos benefícios ou dos prejuízos que tais hábitos podem causar, objeto de profundos e variados estudos psicológicos e sociológicos ${ }^{430}$, é evidente que tais crianças e adolescentes têm muito maior contato com a música do que as gerações passadas, devido às novas tecnologias, ai incluídos a internet, os jogos eletrônicos, os celulares e os digital audio players. Em suma, ouve-se muito mais música atualmente do que há vinte anos atrás.

A inclusão de obra musical em jogo eletrônico, a exemplo das outras formas de utilização, depende de autorização dos titulares de direitos autorais, o que se dá normalmente mediante o pagamento de valor a ser negociado pelas partes (pelos titulares, normalmente a editora).

428 Baseado nos dizeres de Steve Gordon: "the income from sales of a successful game can rival the financial success of a major motion picture" (GORDON, The future of the music..., p.79).

429 IFPI, IFPI 2007..., p.10.

430 Dentre outros: KIRSH, Steven J. The effects of violent video games on adolescents: The overlooked influence of development. Aggression and Violent Behavior, v.8, n.4, p.377-389, July-August 2003, e a edição especial da conceituada Revista Científica estadunidense Journal of Adolescence: ANDERSON, C.A., FUNK, J.B. e GRIFFITHS, M. D. Video Games and Public Health. Journal of Adolescence, v.27, n.1, p.1-122, February 2004. 


\title{
3.2 OS MECANISMOS TECNOLÓGICOS DE PROTEÇÃO AOS DIREITOS
}

\section{AUTORAIS - DRMS}

Para a indústria fonográfica e demais titulares de direitos autorais que pretendem vê-los continuar assegurados, os mecanismos tecnológicos de proteção aos direitos autorais integram as soluções possíveis.

Importante estudo da Comissão Européia ${ }^{431}$ acerca de mecanismos tecnológicos que visam à proteção aos direitos autorais aponta que o cenário do direito de autor é composto por três aspectos principais: i) direitos e exceções; ii) aplicação dos direitos e iii) gestão dos direitos.

Em sentido semelhante seguem os italianos Gustavo Ghidini e Maria Lillà Montagnani ${ }^{432}$ :

\begin{abstract}
Pode-se dizer instaurado um nível tríplice de proteção às obras digitais on-line: proteção típica do direito de autor (com isso fazendo referência também aos direitos conexos); proteção tecnológica (das quais os DRMs são uma modalidade de efetivação); proteção das medidas tecnológicas em si, mediante introdução de sanções seja pela tentativa de burlar a proteção, seja pela produção, comercialização e distribuição de tecnologias capazes de permitir a burla da proteção tecnológica. Esse nível tríplice de tutela é determinado a partir da conjugação do estipulado nas normas em matéria de: a) informações eletrônicas; b) medidas tecnológicas de proteção e, enfim, c) exceções.
\end{abstract}

Quanto ao primeiro aspecto do estudo da Comissão Européia, já se tratou no presente trabalho acerca dos aspectos patrimoniais dos direitos autorais, assim como dos direitos morais dos criadores intelectuais. Sabe-se que a normativa nacional e internacional busca equilibrar os direitos garantidos aos compositores, intérpretes, produtores e organismos de radiodifusão com as exceções a tais direitos, o que na prática, entretanto, nem sempre ocorre.

431 "The copyright environment consists of three main aspects: rights and exceptions; enforcement of rights; and, management of rights". (COMMISSION OF THE EUROPEAN COMMUNITIES. Digital Rights: Background, Systems, Assessment. Comission Staff Working Paper. Bruxelas, 14 fev. 2002. p.6).

432 Tradução livre de "... può dirsi instaurato un triplice livello di protezione per le opera digitali on line: protezione tipica del diritto d'autore (con ciò facendo riferimento anche ai diritti connessi); - protezione tecnologica (di cui i DRMs sono una modalità di realizzazione); - protezione delle misure tecnologiche in sé, tramite l'introduzione di sanzioni sia per l'aggiramento della protezione, sia per la produzione, commercializzazione e distribuzione di tecnologie in grado di permettere l'aggiramento della protezione tecnologica. Questo triplice livello di tutela è determinato dal combinato disposto delle disposizioni in matéria di: a) informazioni elettroniche; b) misure tecnologiche di protezione e, infine, c) eccezioni". (GHIDINI, Gustavo; MONTAGNANI, Maria Lillà. Esercizio del diritto d'autore e dei diritti conessi in ambiente digitale e dispositivi tecnologici di controlo dell'accesso ai contenuti. In: SPADA, Paolo (Org.). Quaderni di AIDA n. 16: Gestione colletiva dell'oferta e della domanda di prodotti culturali. Milão: Giuffrè, 2006. p.127). 
Sobre o segundo aspecto, a aplicação dos direitos (no sentido do vocábulo em inglês enforcement) se dá pela inclusão, nas leis disciplinadoras, de sanções civis e criminais que sejam eficazes em inibir a infração aos direitos autorais protegidos.

É a tentativa de tornar a lei eficaz por meio da coação, pois se apenas houvesse o mandamento sem a penalidade, difícil seria que a norma fosse observada. Note-se, ainda, no caso específico dos direitos autorais que, mesmo com as severas sanções que se impõem, inclusive penais, a obediência integral às normas protetoras em questão é rara.

O terceiro aspecto apontado pela equipe da Comissão Européia, da gestão dos direitos autorais, é ao mesmo tempo, uma importante ferramenta para que se alcance a almejada proteção aos direitos autorais com o respeito aos limites impostos, assim como auxilia no quesito aplicabilidade da norma, já que se trata de gerir os direitos assegurados de forma eficaz ${ }^{433}$, mormente aqueles de cunho patrimonial.

A gestão dos direitos autorais não constitui qualquer novidade introduzida pela tecnologia digital, visto que já é feita desde os primórdios do direito de autor, pelos próprios interessados (titulares), por meio da via contratual ou por entes públicos ou privados constituídos com finalidade de cobrar os direitos autorais - esses últimos expressamente autorizados por força de lei ou mesmo como representantes de determinadas categorias mediante outorga de poderes específicos.

O que inova é o fato de que hoje se vive na era digital e o estado da técnica possibilita que a cópia seja exatamente igual ao original, tal como a cópia da cópia e assim por diante. $\mathrm{Na}$ atualidade, as obras musicais e suas cópias, autorizadas ou não, transitam digitalizadas pela internet, abrindo uma série de oportunidades de negócios aos titulares de direitos autorais na música, mas também tornando necessária a gestão dos respectivos direitos nesse meio.

De todo modo, a tecnologia se encarrega de proporcionar meios para a solução dos desafios que ela mesma impõe ${ }^{434}$. E não foi diferente no caso dos direitos autorais na

433 "Its scope encompasses the exploitation (on-line and offline) of rights including the commercial or transactional aspects pertaining to distribution, licensing, the relevant applicable law and forum and the conditions of administration of those rights be they by individual, central or collective management". (COMMISSION OF THE EUROPEAN COMMUNITIES, Digital Rights..., p.8).

434"'Numa primeira abordagem poder-se-ia dizer que é na técnica que se poderão encontrar respostas para os problemas na técnica, valendo a máxima de que 'a resposta para os problemas da máquina está na própria máquina'." (PEREIRA, Informática, direito..., p.423). 
música, onde foram desenvolvidas formas de proteção genericamente denominadas de DRM - Digital Rights Management, em vernáculo "gestão de direitos digitais".

Tais mecanismos técnicos de gestão de direitos digitais possibilitam que, de forma integrada, se atinja a proteção nos três aspectos apontados pela equipe da Comissão Européia.

Informa a italiana Deborah De Angelis que, num primeiro momento, os sistemas de DRM

eram considerados exclusivamente como o conjunto daqueles meios técnicos voltados a limitar ou impedir a possibilidade de utilização não-autorizada das obras intelectuais contidas em suporte físico (com particular referência à cópia pessoal e a sua possível distribuição a terceiros), ou, de qualquer modo, em ambiente digital. ${ }^{435}$

Tais mecanismos, que podem ser implementados por meio de programas de computador, dispositivos eletrônicos, ou ambos, evoluíram e atualmente possibilitam que os titulares de direitos autorais controlem suas obras de modo integral, numa conjunção de "técnicas dos gêneros contratuais, negociais, legais e tecnológicas para assegurar que os conteúdos que circulam na rede sejam pagos, garantindo certa flexibilidade no setor em referência"436.

Com efeito, o conteúdo dos DRMs é dúplice, preenchido por elementos informativos e dispositivos técnicos. Os elementos informativos representam a "gestão dos direitos digitais $437 "$, e buscam identificar e descrever a propriedade intelectual e delinear as regras sob as quais será utilizada.

435 Tradução livre de "I sistemi di DRM, secondo l'accezione originaria, erano considerati esclusivamente come l'insieme di quelle misure tecniche volte a limitare o impedire le possibilità di utilizzo non consentito delle opere dell'ingegno contenute in supporti fisici (con particolare riferimento alla copia personale e alla sua possibile distribuzione a terzi), o, comunque, in ambiente digitale." (De ANGELIS, La tutela giuridica..., p.192-193).

436 Tradução livre de "tecniche di tipo contrattuale, negoziale, legale e tecnologiche per assicurare che $i$ contenuti che circolano in rete siano pagati, garantendo una certa flessibilità nel settore di riferimento" (De ANGELIS, La tutela giuridica..., p.193).

437 "The management of digital rights - which refers to the activity of identifying and describing intellectual property and setting the rules under which it can be used". (COMMISSION OF THE EUROPEAN COMMUNITIES, Digital Rights..., p.10). 
A identificação ${ }^{438}$ deve mencionar o nome da obra, do(s) compositor(es) ${ }^{439}$, do(s) intérprete(s) e do titular dos direitos autorais sobre o fonograma ${ }^{440}$, enquanto a descrição explicita as condições sob as quais a obra poderá ser utilizada, por meio de metadata ${ }^{441}$, que significa, em termos simples, "dados a respeito de dados", de modo que a partir da aceitação de tais condições, se estabelece uma relação contratual de licenciamento entre o titular e o usuário.

Podem ser diversas as regras estabelecidas pelo titular de direitos autorais (supostamente) dentro do que lhe assegura a normativa de proteção autoral. Pode, por exemplo, proibir ou limitar a reprodução do arquivo digital, ou mesmo autorizá-la sem limitação. Pode condicionar o acesso ao arquivo, para a execução, mediante o pagamento de subscrição mensal ou de um único valor. As possibilidades são inúmeras.

438 A ISO (Organização Internacional de Estandardização), em vernáculo, lançou os parâmetros a serem utilizados na identificação de composições musicais, representada pela sigla ISWC (International Standard Musical Work Code) e para fonogramas, representada pela sigla ISRC (International Standard Recording Code), que são utilizadas tanto para fins de controle de execução para cobrança pelos entes arrecadadores de direitos autorais quanto também incluídos nos mecanismos tecnológicos de gestão de direitos autorais. É de conhecimento mais antigo dos brasileiros a sigla ISBN, que identifica as obras literárias. Maiores informações em: <http://www.iso.org/iso/en/ISOOnline.frontpage>. Acesso em: 16 ago. 2007.

439 LDA, art. 24, II: "Art. 24. São direitos morais do autor: II - o de ter seu nome, pseudônimo ou sinal convencional indicado ou anunciado, como sendo o do autor, na utilização de sua obra."

440 LDA, Art. 80. Ao publicar o fonograma, o produtor mencionará em cada exemplar:

I - o título da obra incluída e seu autor;

II - o nome ou pseudônimo do intérprete;

III - o ano de publicação;

IV - o seu nome ou marca que o identifique.

441 "Metadata is structured information that describes, explains, locates, or otherwise makes it easier to retrieve, use, or manage an information resource. Metadata is often called data about data or information about information." (NATIONAL INFORMATION STANDARDS ORGANIZATION. Understanding Metadata. Bethesda: NISO Press, 2004. p.1). O mesmo estudo, referência para quem se interessa no tema, aponta a existência de 3 categorias de metadata: descritivas (que auxilia a busca e identificação); estruturais (que indica, por exemplo, como as páginas são ordenadas para formar um capítulo) e; administrativas (que auxilia na gestão, explicitando aspectos técnicos do arquivo e quem pode ter acesso a ele), sendo que metadata de propriedade intelectual se insere nessa categoria. Ainda, sobre o tema, texto científico da Fraunhofer Institute for Digital Media Technology IDMT. Metadata Retrieval and Processing. Disponível em: <http:/www.iis.fraunhofer.de/fhg/Images/MD_gesamt_en_cont_tcm27876020.pdf $>$. Acesso em: 18 ago. 2007. 
Entretanto, para proteger o conteúdo de arquivos digitais e garantir a eficácia das regras de utilização determinadas pelos respectivos titulares ou pelo legislador, foram desenvolvidos os dispositivos técnicos, que representam a "gestão digital dos direitos" 442 .

São exemplos já conhecidos as "travas eletrônicas" existentes nos DVDs ${ }^{443}$, que tanto impedem que sejam feitas cópias quanto dividem o globo em regiões, impossibilitando não somente as cópias não-autorizadas de um DVD, mas que um DVD direcionado ao mercado de determinada região seja executado por aparelho leitor destinado ao mercado de outra.

Os dispositivos tecnológicos utilizam-se da criptografia (meio ativo de proteção) e da esteganografia (meio passivo de proteção) ${ }^{444}$ para assegurar as condições de utilização determinadas pelos titulares de direitos autorais. O usual é que nos sistemas de DRM seja utilizada a conjunção de ambos.

Para Deborah de Angelis ${ }^{445}$ :

Os sistemas de proteção ativa são os mais eficazes enquanto limitam as utilizações consentidas àquelas especificamente previstas no contrato de licença, impedindo a realização de ações adicionais não autorizadas pelo titular do direito.

(...)

442 "The digital management of rights - which refers to the activity of securing the content and enforcing the usage rules set by the rights owner or by policy makers." (COMMISSION OF THE EUROPEAN COMMUNITIES, Digital Rights..., p.10). [grifo nosso]

443 São as tecnologias mais conhecidas, no caso dos DVD's: "Macrovision" e "CSS-Content Scrambler System". Cabe ressaltar que as chaves criptográficas de ambas já foram quebradas e vários programas de computador disponíveis na internet anulam a obrigatoriedade da observância de todas as regras que deveriam ser garantidas por meio de tais dispositivos técnicos.

444 "Le tecnologie di protezione facenti parte del DRM possono essere suddivise principalmente tra sistemi di protezione di tipo attivo e sistemi di protezione di tipo passivo, a seconda delle modalità e del momento in cui si realizza concretamente la protezione stessa." (De ANGELIS, La tutela giuridica..., p.194-195).

445 Tradução livre de "I sistemi di protezione attiva sono i più efficaci in quanto limitano le utilizzazioni consentite a quelle specificatamente previste nel contratto di licenza, impedendo il compimento di ulteriori azioni non autorizzate dall'avente diritto". (...) "Le limitazioni d'accesso al materiale protetto si basano su forme di crittografia asimmetrica che impediscono determinate utilizzazioni dell'opera a chi non sia provvisto di specifiche credenziali di autenticazione e su di un sistema di controllo che verifica la presenza e la genuinità delle credenziali stesse immesse dall'utente". "I sistemi di protezione passiva hanno, a differenza di quelli attivi, una funzione soprattutto informativa. Tali tecnologie operano alla stregua di un marchio digitale, fornendo notizie relative all'autore, al titolare dei diritti, al numero di identificazione dell'opera, al tipo di licenza concessa, al regime dei diritti, ecc." (...) "I sistemi di protezione passiva più utilizzati sfruttano le tecniche del watermarking e del fingerprinting." (De ANGELIS, La tutela giuridica..., p.195 e 198). 
As limitações de acesso ao material protegido se baseiam sobre formas de criptografia assimétrica que impedem determinadas utilizações da obra as quem não esteja munido de específicas credenciais de autenticação e sobre um sistema de controle que verifica a presença e a genuinidade das mesmas credenciais introduzidas pelo usuário.

(...)

Os sistemas de proteção passiva têm, diferentemente daqueles ativos, uma função sobretudo informativa. Tais tecnologias operam nos moldes de uma marca digital, fornecendo informações relativas ao autor, ao titular dos direitos, ao número de identificação da obra, ao tipo de licença concedida, ao regime de direitos, etc.

(...)

Os sistemas de proteção passiva mais utilizados exploram as técnicas do watermarking e do fingerprinting.

\section{Segundo Raul Fernando Weber ${ }^{446}$,}

criptografia é caracterizada como a ciência (ou arte) de escrever em códigos ou em cifras, ou seja, é um conjunto de métodos que permite tornar incompreensível uma mensagem (ou informação), de forma a permitir que apenas as pessoas autorizadas consigam decifrá-la e compreendê-la.

Consiste, basicamente, no processo em que a informação é "embaralhada" e somente tem acesso a ela aquele que detém a chave pública correspondente à chave privada do titular dos direitos autorais ${ }^{447}$, no caso da música digital.

A esteganografia, termo de origem grega que significa "escrita oculta"448, consiste, no que concerne aos DRMs, na ocultação de informações inseridas em outras informações. O watermarking 449 (marca d'água) é uma técnica de identificação que garante a autenticidade e

446 WEBER, Raul Fernando. Criptografia contemporânea. Porto Alegre: UFRGS, 1998. Disponível em: $<$ http://www.inf.ufsc.br/ mauro/curso/redes/cripto.doc>. Acesso em: 22 ago. 2007.

447 "Encryption is the process by which information is 'scrambled' to make it unusable to non-authorised users. One particular system of encryption that is vital to DRM systems is the so-called 'Public-Private Key'. Once encryption has been effected using the Public Key (which can quite safely be made known), decryption can only be done using the complementary Private Key, which is not made available to anyone except the owner." (COMMISSION OF THE EUROPEAN COMMUNITIES, Digital Rights..., p.10-11).

448 "Stenografia è un termine di origine greca che significa scrittura nascosta." (De ANGELIS, La tutela giuridica..., p.198).

449 Watermarking é o termo em inglês para o processo que resulta na conhecida "marca d'água", presente em cédulas de dinheiro e visível quando se opõe a nota a uma fonte luminosa. Percebe-se da leitura de autores das mais diversas nacionalidades que convencionou-se pela utilização do termo em inglês, em se tratando do processo digital de "escrita oculta". Para a Comissão da Comunidade Européia: "Watermarking is an identification technique, which can guarantee the integrity and authenticity of digital content. It allows the protection system to be incorporated for the first time into the "fabric" of the content, rather than being added on as separate information. If, for example, a DVD is copied, the watermark follows the copy, no matter how the copying occurred." (COMMISSION OF THE EUROPEAN COMMUNITIES, Digital Rights..., p.10-11). No âmbito musical digital, a utilização de tal tecnologia não causa qualquer distorção na experiência sonora do ouvinte, conforme informam em 
a integridade de determinado conteúdo digital e tem como finalidades: a) certificação da propriedade (ou da paternidade da obra); b) controle de acesso (ou seja, consentir as ações determinadas no contrato de licença); c) monitoramento das cópias ilegais. Tais finalidades também correspondem ao fingerprinting (marca digital), pelo qual se estampa uma "digital" do usuário licenciado da obra musical digital e, no caso de reprodução indevida, o titular toma conhecimento de tal fato 450 .

Já o audio fingerprinting é utilizado para a identificação de determinada obra musical digital, a partir de alguns fragmentos, bem como saber de que forma ela está sendo utilizada. É de grande valia, por exemplo, para que titulares de direitos autorais saibam exatamente em que estação de rádio está sendo transmitida determinada música, com detalhes como horário, número de vezes etc ${ }^{451}$.

apurado estudo técnico os pesquisadores alemães C. Neubauer e J. Herre, do Fraunhofer-Institut für Integrierte Schaltungen IIS: "The results of objective measurements and listening tests were in good agreement, showing that the system introduced only a negligible amount of audible distortion into the audio signal. At the same time a good data transmission was achieved with fairly low channel bit error rates. Based on these evaluations it seems feasible to apply both watermarking and preserve a high audio quality when using sophisticated schemes which sufficiently consider the perceptual aspects of watermarking." (NEUBAUER, Christian; HERRE, Jürgen. Digital Watermarking and its Influence on Audio Quality. Erlangen: Fraunhofer Institute for Integrated Circuits IIS, 1998. p.11). Para aprofundamento no tema, outro artigo desses mesmos autores: NEUBAUER, Christian; HERRE, Jürgen. Advanced Watermarking and Its Applications. Erlangen: Fraunhofer Institute for Integrated Circuits IIS, 2000.

450 "Pertanto, i sistemi di watermarking, nell'ambito della amministrazione digitale dei diritti, presentano le seguenti finalità: a) certificazione della proprietà (ovvero della paternità); b) controllo dell'accesso (ovvero consentire le azioni determinate nel contratto di licenza); c) monitoraggio delle copie illegali)". "Il fingerprinting sfrutta gli stessi principi e le stesse tecniche del watermarking ma è stato improntato, soprattutto, all'identificazione dell'utente finale del contenuto protetto.. (De ANGELIS, La tutela giuridica..., p.199-200).

451 Os cientistas Eric Allamanche e Dr. Jürgen Herre, do Fraunhofer-Institut für Integrierte Schaltungen IIS e Markus Cremer, do Fraunhofer-Institut für Medientechnologie IDMT receberam, em 2004, importante prêmio pela criação e desenvolvimento do sistema "AudioID" que, com o mínimo de recursos tecnológicos pode ser eficazmente utilizado em todas as espécies de aplicações conhecidas (Disponível em: <http://www.fraunhofer.de/fhg/EN/company/science/Joseph_von_Fraunhofer_Preis_2004.jsp >. Acesso em: 18 ago. 2007). Para aprofundamento no tema, indica-se HELLMUT, Oliver et al. Advanced Audio Identification Using MPEG-7 Content Description. Erlangen: Fraunhofer Institute for Integrated Circuits IIS-A, 2001 e HELLMUT, Oliver et al. Using MPEG-7 Audio Fingerprinting in Real-World Applications. Erlangen: Fraunhofer Institute for Integrated Circuits IIS-A, 2003. 
O presidente e sócio da Apple Inc Steve Jobs apresenta simplificada explicação acerca dos DRMs ${ }^{452}$ :

\begin{abstract}
Para evitar cópias ilegais, os sistemas de DRM deve permitir que apenas dispositivos autorizados executem a música protegida. Se uma cópia de canção protegida por DRM é disponibilizada na Internet, esta não deverá poder ser executada no computador de quem a obteve ou no aparelho musical portátil. Para assegurar isso, um sistema de DRM emprega segredos. Em outras palavras, mesmo quando alguém utiliza as mais sofisticadas travas criptográficas para proteger determinada música, ele pode ainda 'esconder' as chaves que destravam a música no computador do usuário ou no aparelho musical portátil. Ninguém nunca implementou um sistema DRM que não dependa de tais segredos para sua operação.
\end{abstract}

Um exemplo do funcionamento de um sistema DRM para compra de música é o seguinte ${ }^{453}$ : i) o usuário faz o pedido para o conteúdo via sítio de distribuição digital de música. O pedido abrange a determinação do uso específico que será feito do conteúdo (nos modelos atualmente oferecidos, download ou subscrição); ii) há a transação financeira, por canal seguro, tomada em efeito com instituição financeira ou operadora de cartão de crédito; iii) uma vez completada a transação financeira, o distribuidor digital de música introduz o dispositivo tecnológico na música, junto com as regras para o uso, e a envia ao usuário; iv) informações acerca da transação é enviada para o titular de direitos (ou, em alguns casos, ente associativo com poderes para tal) para o futuro acerto de contas referente aos direitos autorais.

São diversos os sistemas de DRM disponíveis para a utilização em música, sendo os mais conhecidos os utilizados pela Apple (FairPlay) e Microsoft (Windows Media DRM).

Os marcos normativos que introduziram a disciplina dos $\mathrm{DRMs}^{454}$, ao inserirem obrigações em relação a medidas de caráter tecnológico e em relação a informações para

452 Tradução livre de: "To prevent illegal copies, DRM systems must allow only authorized devices to play the protected music. If a copy of a DRM protected song is posted on the Internet, it should not be able to play on a downloader's computer or portable music device. To achieve this, a DRM system employs secrets. There is no theory of protecting content other than keeping secrets. In other words, even if one uses the most sophisticated cryptographic locks to protect the actual music, one must still "hide" the keys which unlock the music on the user's computer or portable music player. No one has ever implemented a DRM system that does not depend on such secrets for its operation". (JOBS, Thoughts on music).

453 Baseado em quadro disponível no Estudo do Staff da Comissão Européia (COMMISSION OF THE EUROPEAN COMMUNITIES, Digital Rights..., p.11).

454 Sobre o tema, vide artigo da Professora Pamela Samuelson, do Departamento de Direito da Universidade da Califórnia em Berkeley: SAMUELSON, Pamela. TOWARDS MORE SENSIBLE ANTICIRCUMVENTION REGULATIONS. Palestra apresentada na Financial Cryptography 2000 Conference, 2000. 
gestão de direitos foram: o "Tratado OMPI sobre prestações e fonogramas"455 e o "Tratado

OMPI sobre Direito de Autor"456, ambos denominados pela própria organização internacional

"tratados da internet"457. O Brasil não é signatário desses tratados, enquanto os demais

países das Américas e os Estados Unidos, além dos países da Europa, o são.

455 Tratado da OMPI sobre prestações e fonogramas (WPPT):

"Artigo 18. ${ }^{\circ}$ Obrigações em relação a medidas de carácter tecnológico

As partes contratantes devem assegurar uma protecção jurídica adequada e vias de recurso eficazes contra a neutralização de medidas eficazes de carácter tecnológico de que os artistas intérpretes ou executantes ou os produtores de fonogramas se sirvam no quadro do exercício dos direitos que lhes são reconhecidos no presente tratado e que restrinjam, em relação às suas prestações ou fonogramas, a realização de actos não autorizados pelos artistas intérpretes ou executantes ou pelos produtores de fonogramas em questão, ou não permitidos por lei.

Artigo 19. ${ }^{\circ}$ Obrigações em relação a informações para a gestão dos direitos

1. As partes contratantes devem assegurar vias de recurso adequadas e eficazes contra qualquer pessoa que realize deliberadamente qualquer dos actos a seguir indicados, sabendo, ou, no que se refere a recursos de carácter civil, tendo motivos suficientes para saber, que esse acto irá induzir, permitir, facilitar ou dissimular uma infracção a qualquer direito abrangido pelo disposto no presente tratado:

i) A supressão ou alteração não autorizada de quaisquer informações electrónicas para a gestão dos direitos;

ii) A distribuição, importação para distribuição, radiodifusão, comunicação ou colocação à disposição do público não autorizada de prestações, cópias de prestações fixadas ou fonogramas, sabendo que foram suprimidas ou alteradas sem autorização informações electrónicas para a gestão dos direitos.

2. Para efeitos do disposto no presente artigo, entende-se por 'informações para a gestão dos direitos' as informações que identifiquem o artista intérprete ou executante, a prestação do artista intérprete ou executante, o produtor do fonograma, o fonograma, o titular de qualquer direito sobre a prestação ou o fonograma, ou informações acerca das condições de utilização da prestação ou do fonograma, e quaisquer números ou códigos que representem essas informações, quando qualquer destes elementos de informação acompanhe uma cópia de uma prestação fixada ou de um fonograma ou apareça no quadro da comunicação ou da colocação à disposição do público de uma prestação fixada ou de um fonograma." (Disponível em: $<$ http://eur-lex.europa.eu/LexUriServ/LexUriServ.do?uri=CELEX:22000A0411(02):PT:HTML>. Acesso em: 19 ago. 2007).

456 Não se repetirão aqui os termos das obrigações em relação a medidas de caráter tecnológico e das obrigações em relação a informações para a gestão dos direitos, já que são praticamente idênticos no Tratado da OMPI sobre Direito de Autor (WCT) e no Tratado da OMPI sobre prestações e fonogramas (WPPT), somente havendo alterações no que diz respeito aos sujeitos, os autores no WCT e os titulares de direitos conexos no WPPT. O texto completo do WCT está disponível em: <http://eur-lex.europa.eu/ LexUriServ/LexUriServ.do?uri=CELEX:22000A0411(01):PT:HTML>. Acesso em: 19 ago. 2007.

457 "The purpose of the two new WIPO treaties is to update and improve the protection of the already existing copyright and related rights treaties. Those existing treaties date back more than a quarter of a century, to the days before the development of personal computers and the Internet. The WCT and WPPT contain a number of new standards and serve to clarify the older treaties. Most important, the WCT and WPPT provide responses to the challenges of the new digital technologies. For this reason they have come to be known as the 'Internet treaties'." (OMPI - Organização Mundial da Propriedade Intelectual. The WIPO Internet Treaties. Genebra: WIPO, 1999. p.2). "The 1996 WIPO 'Internet' Treaties (WCT and WPPT) define 'rights management information' (RMI) as 'information which identifies the work, the author of the work, the owner of any right in the work, or information about the terms and conditions of use of the work, and any numbers or codes that represent such information, when any of these items of information is attached to a copy of a work or appears in connection with the communication of a work to the public."' (Disponível em: <http://www.wipo.int/meetings/en/2007/sem_cr_ge/>. Acesso em: 19 ago. 2007). 
O conteúdo dos tratados foi introduzido na legislação nacional estadunidense pelo Digital Millenium Copyright Act, de 1998 e, na Comunidade Européia pela Diretiva 2001/29/EC.

Nos Estados Unidos existe uma especial movimentação de acadêmicos ${ }^{458}$ e organizações não-governamentais contra o DMCA. A Electronic Frontier Foundation aponta as principais questões trazidas por tal regulamento federal: i) desencoraja a liberdade de expressão e a pesquisa científica; ii) ameaça o fair use; iii) impede a competição e a inovação, e iv) interfere nas leis sobre invasão de computadores ${ }^{459}$. Do mesmo modo, os usuários não têm recebido com satisfação o que consideram uma intromissão regulamentar indevida, por parte do Estado, com fins de privilegiar aqueles que são tradicionalmente os mais fortes.

Assim, da mesma forma que a indústria fonográfica lançou, nos anos 70, a campanha "home taping is killing music" (a gravação de fitas-cassete em casa está matando

458 "THE DMCA IMPEDES THE PROGRESS OF SCIENCE, is economically unjustifiable, and lacks the balance the Constitution requires of intellectual property legislation". (SAMUELSON, Pamela. DRM \{AND, OR, VS.\} THE LAW. COMMUNICATIONS OF THE ACM, v.46, n.4, p.42, April 2003). "Em ambos os casos, essa lei bizarramente orwelliana foi invocada a fim de controlar a circulação de informações. O Acordo de Copyright do Milênio Digital fez disso uma contravenção." (LESSIG, Lawrence. Cultura livre: como a grande mídia usa a tecnologia e a lei para bloquear a cultura e controlar a criatividade. São Paulo: Trama, 2005. p.168).

459 "The DMCA Chills Free Expression and Scientific Research. Experience with section 1201 demonstrates that it is being used to stifle free speech and scientific research. The lawsuit against 2600 magazine, threats against Princeton Professor Edward Felten's team of researchers, and prosecution of Russian programmer Dmitry Sklyarov have chilled the legitimate activities of journalists, publishers, scientists, students, programmers, and members of the public.

The DMCA Jeopardizes Fair Use. By banning all acts of circumvention, and all technologies and tools that can be used for circumvention, the DMCA grants to copyright owners the power to unilaterally eliminate the public's fair use rights. Already, the movie industry's use of encryption on DVDs has curtailed consumers' ability to make legitimate, personal-use copies of movies they have purchased.

The DMCA Impedes Competition and Innovation. Rather than focusing on pirates, many copyright owners have wielded the DMCA to hinder their legitimate competitors. For example, the DMCA has been used to block aftermarket competition in laser printer toner cartridges, garage door openers, and computer maintenance services. Similarly, Apple invoked the DMCA to chill RealNetworks' efforts to sell music downloads to iPod owners.

The DMCA Interferes with Computer Intrusion Laws. Further, the DMCA has been misused as a general-purpose prohibition on computer network access which, unlike most computer intrusion statutes, lacks any financial harm threshold. As a result, a disgruntled employer has used the DMCA against a former contractor for simply connecting to the company's computer system through a VPN". (EFF ELECTRONIC FRONTIER FOUNDATION. Unintended Consequences: Seven Years under the DMCA, versão 4, abril de 2006. Disponível em: <http://www.eff.org/IP/DMCA/unintended_consequences.php>. Acesso em: 19 ago. 2007). 
a música), alguns usuários lançaram agora sua paródia, a campanha "DRM is killing music"

(DRM está matando a música), conforme se vê a seguir 460 :

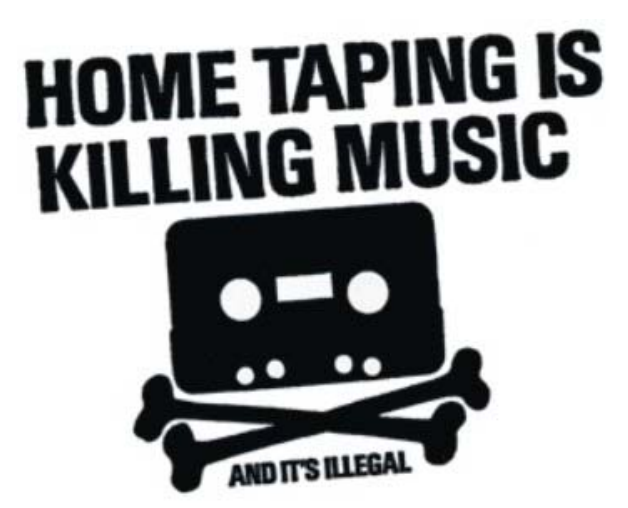

Conforme já exposto, o Brasil não é signatário dos tratados OMPI que instituíram tal previsão dos DRMs, portanto não estaria obrigado a inserir qualquer disposição a respeito. Entretanto, a Lei n. ${ }^{\circ}$ 9.610/98, que versa sobre os direitos autorais, trouxe estampada a proteção dos mecanismos tecnológicos na sua forma mais completa:

\begin{abstract}
Art. 107. Independentemente da perda dos equipamentos utilizados, responderá por perdas e danos, nunca inferiores ao valor que resultaria da aplicação do disposto no art. 103 e seu parágrafo único ${ }^{461}$, quem:

I - alterar, suprimir, modificar ou inutilizar, de qualquer maneira, dispositivos técnicos introduzidos nos exemplares das obras e produções protegidas para evitar ou restringir sua cópia;

II - alterar, suprimir ou inutilizar, de qualquer maneira, os sinais codificados destinados a restringir a comunicação ao público de obras, produções ou emissões protegidas ou a evitar a sua cópia;

III - suprimir ou alterar, sem autorização, qualquer informação sobre a gestão de direitos;

IV - distribuir, importar para distribuição, emitir, comunicar ou puser à disposição do público, sem autorização, obras, interpretações ou execuções, exemplares de interpretações fixadas em fonogramas e emissões, sabendo que a informação sobre a gestão de direitos, sinais codificados e dispositivos técnicos foram suprimidos ou alterados sem autorização.
\end{abstract}

460 Logomarca extraída de "Wikipedia, a enciclopédia livre". Disponível em: <http://pt.wikipedia.org/wiki/ Imagem:DRM_Is_Killing_Music.png>. Acesso em: 24 ago. 2007.

461 Lei n. ${ }^{\circ}$ 9.610/98: "Art. 103. Quem editar obra literária, artística ou científica, sem autorização do titular, perderá para este os exemplares que se apreenderem e pagar-lhe-á o preço dos que tiver vendido.

Parágrafo único. Não se conhecendo o número de exemplares que constituem a edição fraudulenta, pagará o transgressor o valor de três mil exemplares, além dos apreendidos." 
Diante disso, os sistemas de DRM encontram expressa previsão legal no Brasil, pela proteção que lhes é concedida por sanção à sua burla, conforme disposto no art. 107 da lei autoral vigente.

Perceba-se, outrossim, que a proteção autoral e dos titulares de direitos conexos já é estipulada em outros pontos da lei. O que tal artigo incluiu na lei específica dos direitos autorais foi a sanção não à infração direta de tais direitos mas à burla de dispositivos tecnológicos visando à gestão e identificação daqueles, mas que acaba por ser igualmente considerada genericamente como sanção aos direitos autorais, mesmo não sendo o caso ${ }^{462}$.

Um exemplo prático da infração a tal norma sem necessariamente haver infração aos direitos autorais é a atitude dos sítios brasileiros de venda de música digital on-line que ensinam e estimulam seus usuários a burlar os mecanismos de proteção e gestão de direitos para que as canções sejam inseridas no iPod. Supõe-se que, ao fazer isso, os sítios dispõem de autorização dos respectivos titulares das músicas, com o que a proteção autoral está respeitada. Entretanto, o usuário, independente dessa presumida autorização, incorre no ilícito do supramencionado artigo.

Sobre os riscos de tal adoção legislativa já alertava o autor português José de Oliveira Ascensão463, ao comentar a Proposta que originou a Diretiva 2001/29/CE:

\footnotetext{
Mas nem sequer é verdade que, na disciplina dessa matéria, o que esteja em causa seja a tutela do direito de autor.

Se o fulcro da proteç̧ão do autor está no direito de colocação em rede à disposição do público, a entrada não autorizada na base de dados em linha, por exemplo, não representa violação do direito de autor; tal como não representa violação do direito de autor, para manter o mesmo símile, a entrada sorrateira num cinema sem pagar bilhete.

$\mathrm{O}$ autor já autorizou que a obra fosse colocada à disposição do público. A penetração não autorizada na base de dados não viola o direito de autor: viola o direito do produtor de manter reservado o acesso.

(...)

É claro que o autor pode estar também interessado em que o acesso continue reservado. Pode ter até estipulado que a contrapartida da autorização seria função do rendimento obtido com a exploração da obra. Mas esse é um interesse prático, e não jurídico. $\mathrm{O}$ seu direito foi já antes exercido e está satisfeito. $\mathrm{O}$ invasor da base de dados não viola o direito de autor, mas sim o direito do produtor.
}

462 A tal respeito já previa o português Alexandre Dias Pereira em 1998, data da escrita de sua obra, no advento dos tratados OMPI, porém antes da Diretiva 2001/29/CE: "Parece consensual, actualmente, que o contornamento de dispositivos técnicos de protecção de direitos de autor poderá constituir uma infracção a estes direitos, em termos que serão sancionados pelo direito internacional, europeu e nacional." (PEREIRA, Informática, direito..., p.427).

463 ASCENSÃO, José de Oliveira. O direito de autor no ciberespaço. In: internet e sociedade da informação. Coimbra: Almedina, 2001. p.165. Estudos sobre direito da 
E com isso revela-se-nos algo mais, na ambígua postura do direito de autor na sociedade da informação. Nestas hipóteses, não há sequer tutela do autor que, afinal, reverta em benefício do produtor; há antes tutela directa do produtor, sob a alegação (inexacta) de que se violam obras protegidas pelo direito de autor. É o produtor, agora, quem ocupa directamente o primeiro plano.

E como tanto faz que haja ou não obras protegidas, porque o que se torna decisivo é haver uma restrição de acesso, temos de reconhecer que, em tudo isto, não só o autor se apaga: apaga-se também o próprio direito de autor.

O que interessa, na sociedade da informação, é que o produtor seja remunerado. Haver ou não obras protegidas dentro do conteúdo transmitido tornar-se-á secundário, porque as remunerações serão normalmente por tempo ou avença, abstraindo do conteúdo da mensagem transmitida. Só em hipóteses especiais, quando se pactuar uma remuneração específica por categoria de obras, o facto de se tratar de obra protegida pode ter ainda algum significado.

Mas não é só por a remuneração do acesso se fazer por obra que o direito de autor influi nela. $\mathrm{O}$ acesso a uma sinfonia clássica pode fazer-se nas mesmas condições que o acesso a obra contemporânea, não obstante aquela sinfonia não ser obra intelectual protegida.

Tudo se baralha, pois. O problema jurídico da sociedade da informação é o problema das próprias mensagens em rede. Ao autor cabe autorizar a integração da obra em rede mas a seguir perde todo o significado. A proposta de directriz, referindo embora o direito de autor, serve materialmente a protecção do produtor.

Percebe-se, outrossim, que a normativa internacional (tratados OMPI: WCT e WPPT) - acompanhada pela nacional Lei n. ${ }^{\circ}$ 9.610/98 - criou um estatuto diferenciado entre as obras "tradicionais" e as obras "on-line", em vista da proteção conferida a essas últimas ${ }^{464}$. No "mundo real" um livro pode ser lido e posteriormente emprestado a um amigo, enquanto no "mundo virtual", com os DRMs, a depender da licença, isso não é possível.

A crítica aos $\mathrm{DRMs}^{465}$ que mais repercussão tem causado é a possibilidade de, com esses mecanismos tecnológicos, se vedar o acesso a conteúdos permitidos ${ }^{466}$, obras

464 No mesmo sentido, Gustavo Ghiaini e Maria Lillà Montagnani: "Infatti, come prima ricordato, sia il DMCA statunitense, sia la direttiva comunitaria in materia di società dell'informazione (e, conseguentemente la nostra l.a.) introducono un regime delle eccezioni al diritto d'autore e ai diritto connessi, per le opere on line tecnologicamente protette." (GHIDINI e MONTAGNANI, Esercizio del diritto..., p.131).

465 "DRM is more aptly described as 'code as code' - a private governance system in which computer program code regulates which acts users are (or are not) authorized to perform - than as a rights management regime or as a copyright-enforcement mechanism. An alternative phrase for DRM is 'digital restrictions management,' given its use by copyright industries to restrict user rights". (SAMUELSON, DRM \{AND, OR, VS. $\}$ THE LAW, p.42)

466 Para Lawrence Lessig: "à medida que tecnologias digitais se desenvolvem, torna-se óbvio para muita gente que imprimir todo mês milhares de cópias de periódicos e enviá-los para bibliotecas talvez não seja o modo mais eficiente de se distribuir conhecimento. Em vez disso, um número cada vez maior de periódicos estão se tornando eletrônicos, e as bibliotecas e seus usuários têm acesso aos periódicos eletrônicos através de sites protegidos por senha. Algo assim vem acontecendo na área de direito por quase 30 anos: os periódicos Lexis e Westlawbb têm disponibilizado versões eletrônicas de relatórios de casos para assinantes de seu serviço. Embora uma opinião da Suprema Corte não seja protegida por copyright, e qualquer pessoa seja livre para ir a uma biblioteca e ler sobre ela, os periódicos acima são igualmente livres para cobrar de seus usuários pelo privilégio acessar uma determinada opinião da 
caídas em domínio público ${ }^{467}$ ou mediante situações que caracterizem limites aos direitos autorais como, por exemplo, o direito de crítica ${ }^{468}$ ou paródia ${ }^{469}$.

Assim, adotando-se o exemplo hipotético: um usuário dotado de conhecimentos

técnicos descobre que o arquivo digital de determinada obra musical a qual procura há tempos,

Suprema Corte. Em geral não há nada de errado com isso e a possibilidade de cobrar por acesso, mesmo a material de domínio público, é realmente um bom incentivo para que as pessoas desenvolvam formas novas e inovadoras de disseminar o conhecimento. A lei está de acordo, e por isso periódicos como Lexis e Westlaw puderam florescer. Se não há nada de errado em vender o que é de domínio público, então, em princípio, não haveria nada de errado em vender acesso a material que não é de domínio público. Mas e se o único jeito de conseguir acesso a dados científicos e sociais fosse por meio de serviços pagos? E se ninguém pudesse ter acesso a estes dados a não ser que pagasse assinatura? Como muitos começam a notar, essa é cada vez mais a realidade dos periódicos científicos. Quando eles eram distribuídos em forma de papel, as bibliotecas podiam disponibilizá-los a qualquer um que tivesse acesso ao acervo. Assim, pacientes de câncer podiam se tornar especialistas em câncer, pois as bibliotecas lhes davam acesso. Pacientes que tentavam entender os riscos de certos tratamentos podiam pesquisar tais riscos lendo tudo disponível sobre o assunto. Essa liberdade era, portanto, uma função da instituição das bibliotecas (normas) e da tecnologia de periódicos em papel (arquitetura) - a saber, era muito difícil controlar o acesso a um periódico em papel. À medida que os periódicos se tornam eletrônicos, os editores têm exigido que as bibliotecas não forneçam acesso irrestrito aos periódicos. Isso significa que as antigas liberdades de consulta de impressos em bibliotecas começam a desaparecer. Assim como aconteceu com a privacidade e com o software, uma tecnologia em constante mudança e o mercado diminuem uma liberdade que nos era garantida. Essa liberdade cada vez menor leva muitos a tomar medidas enérgicas para restaurar o que se perdeu. A Biblioteca Pública da Ciência (PloS), por exemplo, é uma corporação sem fins lucrativos dedicada a disponibilizar pesquisas científicas pela Internet. Os autores de obras científicas as enviam para o órgão, e elas são sujeitas a uma avaliação prévia. Caso uma obra seja aceita, é então depositada em um arquivo público eletrônico, a que se pode acessar de forma gratuita e permanente. A PloS também vende uma versão impressa de seu trabalho, mas o copyright para o periódico impresso não inibe o direito de ninguém redistribuir a obra gratuitamente. Esse é um dos muitos esforços para restaurar uma liberdade que nos era garantida, mas que agora está ameaçada por tecnologias e mercados em constante mudança. Não há dúvidas de que a alternativa compete com editores tradicionais e seus esforços para ganhar dinheiro com a distribuição exclusiva de conteúdo. Mas a competição em nossa tradição é supostamente uma coisa boa - especialmente quando ajuda a disseminar conhecimento e ciência" (LESSIG, Cultura livre..., p.273-274). O mesmo autor, entre as páginas 161 e 165 dessa obra, traz interessante exemplo prático da utilização de bloqueios eletrônicos por sistema de DRM introduzido no software Adobe Reader, para leitura de livros no formato eletrônico, no qual sob o termo "permissões" contraditoriamente "travam" (vedam) diversas possibilidades, a exemplo de impressão, cópia e leitura em voz alta de obras caídas em domínio público.

467 LDA, "Art. 45. Além das obras em relação às quais decorreu o prazo de proteção aos direitos patrimoniais, pertencem ao domínio público:

I - as de autores falecidos que não tenham deixado sucessores;

II - as de autor desconhecido, ressalvada a proteção legal aos conhecimentos étnicos e tradicionais".

Sobre o tema domínio público em relação aos direitos autorais é referência a obra "Free Culture" do Professor da Faculdade de Direito da Universidade de Stanford, Lawrence Lessig, traduzida ao português e editada pela Trama Universitária: LESSIG, Cultura livre..., 2005.

468 LDA, "Art. 46. Não constitui ofensa aos direitos autorais:

III - a citação em livros, jornais, revistas ou qualquer outro meio de comunicação, de passagens de qualquer obra, para fins de estudo, crítica ou polêmica, na medida justificada para o fím a atingir, indicando-se o nome do autor e a origem da obra."

469 LDA, "Art. 47. São livres as paráfrases e paródias que não forem verdadeiras reproduções da obra originária nem lhe implicarem descrédito." 
já caída em domínio público, se encontra em determinado sítio da internet, entretanto sob mecanismos de DRM e decide burlar a proteção. Muito embora não esteja infringindo direitos autorais, ele está violando o previsto no art. 107, I da Lei n. ${ }^{\circ}$ 9.610/98470.

Ainda, e não menos grave, é o fato de que enquanto os direitos autorais protegidos pelos DRM's têm prazo de duração máximo estipulado em 70 anos a contar do primeiro dia de janeiro do ano seguinte à morte do autor ${ }^{471}$, os mecanismos em si podem ter validade perpétua. Noutras palavras, a obra cai em domínio público, mas o acesso continua sendo vedado se não forem observadas as condições impostas por quem definiu os mecanismos de gestão dos direitos.

Enfim, alerta Alexandre Dias Pereira, ao comentar os DRMs ${ }^{472}$ :

Estes dispositivos não apenas protegem obras protegidas pelo direito de autor e pelos direitos conexos, mas também todos os conteúdos informativos em suporte electrónico. Ora a proteção jurídica de tais sistemas técnicos poderá eclipsar os tradicionais limites ao direito de autor, gerando uma nova forma de propriedade baseada sobretudo no conceito de acesso condicional.

(...)

Com efeito, por força de tais mecanismos técnicos, a obra passará a ser protegida, não porque seja original, mas porque foi objecto de um dispositivo tecnológico de proteção (por ex., uma aplicação criptográfica). Assim, a sua reprodução será interdita, não porque o direito de autor reserve esta prerrogativa ao autor, mas, pura e simplesmente, porque os mecanismos técnicos a impedem. Isto significa ainda que a protecção tecnológica será extensível a tudo o que o titular desejar proteger, quer se trate de obras originais ou não, e quer estejam ou não no domínio público. Tal protecção não resultará de um sistema de direitos exclusivos mas antes de dispositivos tecnológicos, não sendo os poderes dos titulares e a duração de protecção definidos por lei, mas antes pelo titular com o auxílio da máquina.

470 Apontam Gustavo Ghidini e Maria Lillà Montagnani acerca da antecipação do limiar do direito de autor e da inversão do ônus da prova em desfavor do usuário, no caso da proteção aos DRM's como inserido nas normas: "L'individuazione di questo nuovo illecito pare determinare un'anticipazione della soglia di protezione che il diritto d'autore ha tradizionalmente riservato alle opere creative. (...) In questo contesto è stato anche sottolineato come l'avanzamento' della soglia di protezione realizzi un'inversione dell'onere della prova e sposti il costo giudiziale dei procedimenti aventi ad oggetto violazioni del diritto d'autore (o copyright infringement). Invero, la violazione di una misura tecnologica è violazione di per sé e permette al titolare (anche presunto) dei diritti d'autore o connessi di agire contro colui che ha operato l'elusione. Poco importa che l'elusione sia stata effettuata al fine di fruire di un'opera che non è protetta dal diritto d'autore (in quanto, ad esempio, caduta in pubblico dominio o non avente $i$ requisiti necessari per accedere alla protezione). In tale ipotesi, dunque, colui che ha operato l'elusione è chiamato a provare la liceità della propria azione e sostiene il costo giudiziale di dimostrare che l'opera era liberamente accessibile poiché non protetta dal diritto d'autore. Nel diritto d'autore (o copyright) classico, invece, il costo giudiziale ricade sul titolare del diritto d'autore o di diritti connessi che voglia vedere riconosciuta la violazione dei propri diritti e agisca, quindi, dimostrando, in primo luogo, la titolarità del diritto e, in secondo luogo, l'attività illecita." (GHIDINI e MONTAGNANI, Esercizio del diritto..., p.130).

471 LDA, "Art. 41. Os direitos patrimoniais do autor perduram por setenta anos contados de 1 . $^{\circ}$ de janeiro do ano subseqüente ao de seu falecimento, obedecida a ordem sucessória da lei civil."

472 PEREIRA, Música e electrónica..., p.317 e 333. 
Com efeito, recebidos pela indústria fonográfica como a solução para os desafios impostos pela tecnologia, os DRMs, ao mesmo tempo em que possibilitam adequada gestão dos direitos por parte de seus titulares, podem infringir direitos de terceiros, mormente aqueles da coletividade consumidora de obras musicais.

\subsubsection{Os DRMs e o Novo Paradigma dos Direitos Autorais na Música Digital}

Antes do advento da tecnologia digital, a proteção aos direitos autorais na música se dava mediante as garantias legais concedidas aos respectivos titulares, quer fossem compositores, quer titulares de direitos conexos. Na atualidade, além do que o direito de autor tradicional versa, outras formas mais eficazes de proteção são utilizadas nos ambientes informáticos de rede: o contrato e os mecanismos tecnológicos ${ }^{473}$.

Conforme já visto, o titular de direitos autorais sobre determinado fonograma pode, por meio dos sistemas de DRM, além de identificar a obra, determinar os parâmetros para a sua utilização, autorizando certos usos e proibindo outros, assim como rastrear eventuais reproduções indevidas. "É ainda concebível que estes dispositivos tecnológicos permitam informar os titulares de direitos de que o utilizador está a abusar dos direitos de acesso a estas obras." 474

Todavia, parece claro também que a utilização de tais mecanismos tecnológicos traz efetividade ao escopo principal, que é a proteção dos direitos autorais, pela adequada gestão que é tornada possível e conseqüente retorno do direito de autor aos seus princípios ${ }^{475}$.

473 Cf. GEIGER, Christophe. Droit d'auteur et droit du public à l'information. Paris: LITEC, 2004. p.201: "Dans l'environnement analogique, les titulaires de droits se servent des prérogatives que leur confère le droit d'auteur afin d'assurer la protection de leurs auvres. Par contre, dans l'environnement numérique, ces titulaires de droit sont tentes de se tourner vers d'autres modes de protection pouvant se révéler plus efficace que le droit d'auteur: le contrat e les mesures techniques."

474 PEREIRA, Informática, direito..., p.420.

475 É nesse sentido o que alerta Alexandre Dias Pereira: "acresce que, ao contrário da radiodifusão e da sua cultura de consumo em massa, os sistemas informáticos em rede permitem o estabelecimento de um laço entre a utilização individual e a obra individual. O que, no quadro das medidas de carácter tecnológico de proteção e das informações digitais para a gestão de direitos, sustenta-se poder tornar possível o reencontro do direito de autor com os seus princípios, reforçando-o", para depois ressaltar, com base em José de Oliveira Ascensão que "todavia, não deverá esquecer-se que, como linha de princípio, em razão do seu fundamento de promoção da liberdade de criação cultural, o direito de autor prossegue, de igual modo, fins de interesse geral, os quais justificam determinados limites, como sejam as regras da utilização livre para fins de informação, arquivo, ensino ou investigação; limites cujo apagamento não deverá ser justificado por esse 'slogan' que a sociedade da informação é. Pois que, nem tudo o que é tecnologicamente possível e economicamente sustentável, será juridicamente admissível" (PEREIRA, Informática, direito..., p.36 e 67). 
O problema é que a implantação de tais mecanismos pode não somente representar um elemento de gestão por parte dos titulares dos direitos autorais quanto, no limite, caracterizar: i) abuso de poder contratual em face do consumidor, a quem resta somente optar se aceita ou não os termos da licença (em que pese o fato de que diversas das cláusulas são nulas em face das normas de proteção do consumidor ${ }^{476}$ ). É um exemplo de cláusula adotada por empresas que perfazem a venda de músicas digitais on-line aquela que transfere ao usuário a responsabilidade de tomar conhecimento individual dos limites da licença outorgada ${ }^{477}$; ii) abuso de direito 478 na medida em que se impossibilita a execução de obra musical sem a prévia aquisição de licença, ignorando-se as limitações aos direitos autorais tais como postas na lei regente, bem como o domínio público ${ }^{479}$; iii) num caso extremo, instrumento de autotutela ao serem inseridos códigos computacionais maliciosos que visem causar danos ao sistema do usuário infrator dos termos contidos na licença e aplicados nos dispositivos tecnológicos.

476 Foge do escopo do presente estudo fazer a análise sob o prisma do Direito das Relações de Consumo, entretanto é nítida a infração a diversos de seus postulados, dentre os quais o dever de informação.

477 Cláusula quarta do contrato do sítio "iMusica", que trata "Da Licença e Limitações de Uso": "(...) A limitação da emissão de licenças e cópias de CDs graváveis varia de acordo com cada gravadora que tem suas próprias regras, portanto a iMusica recomenda que o usuário esteja atento aos termos de cada uma." Disponível em: <http://www.imusica.com.br/TermosDeUso.aspx>. Acesso em: 19 ago. 2007.

478 Questiona Christophe Caron se "a teoria do abuso de direito pode ser aplicada ao direito do autor? Mais precisamente, o titular do direito de autor pode abusar de seu direito ao exercê-lo? Se a possibilidade de um abuso é admitida, é necessário então pesquisar se está na presença de um abuso de direito ou da aplicação de um conceito equivalente ou vizinho. O estudo da aplicabilidade da teoria do abuso de direito para o direito de autor necessita, por conseqüência, pesquisar se as diferentes prerrogativas que constituem o direito do autor são suscetíveis ao abuso, e, nas hipóteses onde este é o caso, de distinguir o abuso de direito das noções jurídicas similares ou vizinhas". Tradução livre de "La théorie de l'abus de droit peut-elle s'appliquer au droit d'auteur? Plus précisément, le titulaire du droit d'auteur peut-il abuser de son droit en l'exerçant? Si la possibilite d'un abus est admise, il est alors nécessaire de rechercher si l'on est en présence d'un abus de droit ou de l'application d'un concept équivalent ou voisin. L'étude de l'applicabilité de la théorie de l'abus de droit d'auteur nécessite, par conséquent, de rechercher si les différentes prérogatives qui constituent le droit d'auteur sont susceptibles d'abus, et, dans les hypothèses où cela est le cas, de distinguer l'abus de droit des notions juridiques similaires ou voisines." (CARON, Abus de droit..., p.21).

479 É o alerta de Pamela Samuelson: "While DRM systems can certainly prevent illegal copying and public distribution of copyrighted works, they can do far more; they can as easily prevent the copying and distribution of public-domain works as copyrighted works." (SAMUELSON, DRM \{AND, OR, VS.\} THE LAW, p.42). 
A atual conjunção entre contrato e dispositivos tecnológicos leva à conclusão de que efetivamente se opera, nos dizeres de Gustavo Ghidini e Maria Lillà Montagnani480, uma contratualização (ou privatização) dos direitos autorais, em especial no que diz respeito aos limites impostos ${ }^{481}$, em detrimento do usuário.

Observa Alexandre Dias Pereira ${ }^{482}$ que:

\begin{abstract}
Acresce que, ao mesmo tempo, as licenças contratuais de utilização assumem uma importância acrescida. É o problema da determinação, em cada fase de exploração, que direitos deverão ser transmitidos, em que condições e a que preço, numa cadeia contratual que ligará o autor, o produtor das obras, o distribuidor das bases de dados, e, ainda, o utilizador final. Sendo que a contratualização da utilização final da obra é de molde a gerar "a dependência do utilizador em relação ao titular de direitos".
\end{abstract}

480 "E' proprio in questo contesto che viene operata la 'contrattualizzazione' (o 'privatizzazione') delle eccezioni per le opere on-line tecnologicamente protette. Fenomeno che desta, peraltro, forti perplessità." (GHIDINI e MONTAGNANI, Esercizio del diritto..., p.128).

481 São legalmente consideradas limitações aos direitos autorais, aplicáveis na música, conforme a lei autoral vigente, as seguintes:

Art. 46. Não constitui ofensa aos direitos autorais:

I - a reprodução:

d) de obras literárias, artísticas ou científicas, para uso exclusivo de deficientes visuais, sempre que a reprodução, sem fins comerciais, seja feita mediante o sistema Braille ou outro procedimento em qualquer suporte para esses destinatários;

II - a reprodução, em um só exemplar de pequenos trechos, para uso privado do copista, desde que feita por este, sem intuito de lucro;

III - a citação em livros, jornais, revistas ou qualquer outro meio de comunicação, de passagens de qualquer obra, para fins de estudo, crítica ou polêmica, na medida justificada para o fim a atingir, indicando-se o nome do autor e a origem da obra;

IV - o apanhado de lições em estabelecimentos de ensino por aqueles a quem elas se dirigem, vedada sua publicação, integral ou parcial, sem autorização prévia e expressa de quem as ministrou;

V - a utilização de obras literárias, artísticas ou científicas, fonogramas e transmissão de rádio e televisão em estabelecimentos comerciais, exclusivamente para demonstração à clientela, desde que esses estabelecimentos comercializem os suportes ou equipamentos que permitam a sua utilização;

VI - a representação teatral e a execução musical, quando realizadas no recesso familiar ou, para fins exclusivamente didáticos, nos estabelecimentos de ensino, não havendo em qualquer caso intuito de lucro;

VII - a utilização de obras literárias, artísticas ou científicas para produzir prova judiciária ou administrativa; VIII - a reprodução, em quaisquer obras, de pequenos trechos de obras preexistentes, de qualquer natureza, ou de obra integral, quando de artes plásticas, sempre que a reprodução em si não seja o objetivo principal da obra nova e que não prejudique a exploração normal da obra reproduzida nem cause um prejuízo injustificado aos legítimos interesses dos autores.

Art. 47. São livres as paráfrases e paródias que não forem verdadeiras reproduções da obra originária nem lhe implicarem descrédito.

Percebe-se, outrossim, que são poucas as limitações aos direitos autorais dispostas na lei, todas constantes de rol taxativo, em contraposição do rol exemplificativo que versa sobre os aspectos patrimoniais do direito de autor: LDA "Art. 29. Depende de autorização prévia e expressa do autor a utilização da obra, por quaisquer modalidades, tais como:".

482 PEREIRA, Informática, direito..., p.417. 
Nessa nova concepção introduzida pelos avanços tecnológicos constata-se uma operação cíclica: i) a norma versa sobre os direitos autorais; ii) o contrato dispõe acerca dos parâmetros da licença sobre os direitos autorais; iii) os DRMs possibilitam a gestão do contrato e, por fim, iv) a norma garante a efetividade dos mecanismos tecnológicos.

É fato que os DRMs podem possibilitar a adequada gestão dos direitos autorais, mas também o é que, na medida em que são lançados, algum hacker ${ }^{483}$ trata de quebrar o código de proteção ${ }^{484}$.

Tem-se, a partir disso, a impressão de que para se atingir um fim (a proteção dos direitos autorais) utiliza-se um meio, o DRM (mecanismo tecnológico de gestão de direitos autorais aliado a um contrato com cláusulas unilateralmente impostas), o qual pode ultrapassar os próprios direitos autorais ${ }^{485}$, com o agravante que a burla de tal mecanismo configura-se ilícita, mesmo nos casos em que não existem direitos a serem protegidos ${ }^{486}$.

483 Para Amaro Moraes e Silva Neto, "hacker é aquele que é atiçado exclusivamente pelo desafio intelectual de romper as defesas de um sistema operacional - e aí encerrar sua batalha mental" e "a grande verdade é que os hackers são muito bons e sabem escrever códigos que realmente funcionam. São pessoas que detêm um conhecimento acima da média, em níveis informáticos. São seres que conhecem quais são as falhas de um sistema operacional ou mecanismos (frutos do conhecimento e da informação) que permitem a invasão de plataformas alheias". Não confundir com o cracker, aquele que, segundo o mesmo autor "é aquele que inicia sua batalha quando do rompimento das defesas do sistema operacional sob ataque, tendo em vista a obtenção de benefícios para si ou para outrem, sempre em detrimento de terceiros" (SILVA NETO, Amaro Moraes e. Resgatemos os hackers. Jus Navigandi, Teresina, ano 4, n.44, ago. 2000. Disponível em: <http://jus2.uol.com.br/doutrina/texto.asp?id=1831 >. Acesso em: 21 ago. 2007). Para aprofundamento no tema: HIMANEN, Pekka. A ética dos hackers e o espírito da era da informação: a importância dos exploradores da era digital. Trad. Fernanda Wolff. Rio de Janeiro: Campus, 2001.

484 "Technological protection systems, no matter how strong or sophisticated, will always be vulnerable to attack from hackers and pirates". (COMMISSION OF THE EUROPEAN COMMUNITIES, Digital Rights..., p.12).

485 "DRM Goes Beyond Copyright", nos dizeres de Pamela Samuelson (SAMUELSON, DRM \{AND, OR, VS.\} THE LAW, p.42).

486 Para Cristophe Geiger, "seulement, la technique n'est pás infaillible, et les dispositifs techniques peuvent être contournés, 'hackés' pour employer la terminologie anglophone. Et face à ce danger s'est rapidement développé le consensus au niveau international que les systèmes techniques, afin de déployer leur efficacité, devaient être protégés juridiquement contre le contournement. Le problème, c'est qu'outre protéger des ouvres, les mesures techniques permettent de protéger des éléments qui ne bénéficient d'aucune protection par le droit d'auteur, des formes non originales, simples informations ou encore des œuvres déjà tombées dans le domaine public. Par conséquent, l'équilibre mis en place par le droit d'auteur à travers les limites à la protection peut se trouver tout simplement balayé par la technique. Protéger juridiquement les systèmes techniques contre le détournement, même lorsque ce détournement vise à permettre à l'utilisateur de bénéficier d'une limite et de procéder ainsi à une utilisation legitime au regard du droit d'auteur, revient à mettre en place une prérogative juridique nouvelle, ce que certains auteurs ont nommé un 'droit d'accès', droit de contrôler l'accès à l'œuvre mais pás uniquement, droit potentiellement sans limite puisque la technique est aveugle face aux limites mises en place par le droit d'auteur." (GEIGER, Droit d'auteur..., p.300-301). 
Daí é de questionar ${ }^{487}$ : se nessa "era do digital" o direito de autor na música, de natureza privada porém resguardado em virtude do interesse público - quer seja conforme a concepção do direito de autor continental, da indissociabilidade da obra protegida em relação ao criador para reconhecê-lo e assim incentivá-lo a produzir mais, quer seja conforme o substrato do copyright, o incentivo à ciência e às artes - do modo com que está sendo conduzido pelos titulares (raramente os autores) efetivamente se atinge o fim colimado ou, conforme têm sido por muitos apontado, transmutou-se para um interesse meramente privado, em constante atrito com o interesse público ${ }^{488}$.

Seria, então, em casos extremos, o retorno da autotutela, na medida em que os meios tecnológicos propiciam condições a tal? Aliás, muito perto o Brasil ficou de ver aprovado Projeto de Lei no Senado Federal, o qual incluía parágrafo que acabava por autorizar o exercício da autotutela em caso de crime de invasão de sistemas informáticos ${ }^{489}$, vez que permitia o acesso a sistemas ou computadores alheios a título de "defesa digital".

Com efeito, proteger o direito do autor e seus conexos representa efetiva evolução e constitui fator positivo à sociedade. Em análise da Lei autoral chega-se à conclusão de que ela confere proteção adequada ao autor, elevando-o ao justo status privilegiado em relação aos demais titulares de direitos dessa natureza.

487 Para Alexandre Dias Pereira, "um problema que se põe aqui é saber se a utilização de dispositivos tecnológicos para proteger as obras digitais nos ambientes em rede e de cabeçalhos contratuais não poderá relegar para segundo plano o direito de autor. Na verdade, sendo as obras protegidas contra utilizações não autorizadas através de dispositivos tecnológicos e mecanismos contratuais, pode perguntar-se se ao direito de autor não estará reservado o papel de justificativo da utilização de meios tecnológicos e contratuais de protecção de obras sob forma digital" (PEREIRA, Informática, direito..., p.421).

488 Essa questão, aliás, sempre esteve presente no direito autoral, no qual sempre se notou certo equilíbrio na norma, que levava em conta "duas exigências contrastantes", conforme Antônio Chaves: "a regulamentação positiva dos resultados da atividade do intelecto resultou sempre de uma escolha e freqüentemente de um compromisso entre duas exigências contrastantes: o interesse da coletividade em utilizar livre e imediatamente o resultado, e o interesse do autor em reservar para si mesmo o emprego econômico, ou ao menos em retirar proveito do aproveitamento alheio" (CHAVES, Direito do autor..., p.8-9). Entretanto, o que se percebe atualmente é que os titulares de direitos autorais (frise-se: não necessariamente os autores) hoje desfrutam de direitos de maior amplitude que o público.

489 Somente após Audiência Pública o relator Senador Eduardo Azeredo acabou por retirar o parágrafo que autorizava a autotutela em questões digitais. É a redação antiga do PLS 76/2000, da qual foi retirado o parágrafo quarto: "Art. 154-A. Acessar rede de computadores, dispositivo de comunicação ou sistema informatizado, sem autorização do legítimo titular, quando exigida:

Pena - reclusão, de 2 (dois) a 4 (quatro) anos, e multa.

$\S 4 .^{\circ}$ Não há crime quando o agente acessa a título de defesa digital, excetuado o desvio de finalidade ou o excesso". 
Entretanto, é fato que se operam cessões das mais variadas, mormente no segmento em estudo, o musical, em que os autores-compositores, conforme lhes é facultado, acabam por transferir na integralidade os direitos referentes às suas obras, problema cuja solução depende de sua vedação na norma. É para o que já alertava, na década de 1970, Fabio Maria De Mattia ${ }^{490}$ :

Somos, integralmente, favoráveis à proibição da cessão dos direitos autorais. O direito positivo, apenas, deveria admitir contratos visando a utilização temporária e econômica da obra. Seria o único modo de resguardar, efetivamente, os direitos do autor.

A disciplina dos direitos conexos conferiu uma série de garantias aos investidores musicais, conforme já visto no Capítulo 1 e, muitas vezes, por mais que a própria lei expressamente preveja que a proteção a tais direitos mantém "intactas e não afeta as garantias asseguradas aos autores das obras literárias, artísticas ou científicas"491, na prática as coisas acabam por se revelar diferentes.

Nessa medida, acaba por se operar ruptura na justificativa da proteção autoral, fixada no interesse público geral da cultura, com que se traz à baila conflitos entre dispositivos constitucionais, alguns inclusive representando garantias fundamentais.

Sob essa perspectiva, resta que o direito de autor, cujos fundamentos constitucionais baseiam-se na garantia do direito de propriedade (art. 5. ${ }^{\circ}, \mathrm{XXII}$ ), portanto vinculado ao cumprimento da função social (art. 5. ${ }^{\circ}$, XXIII) e nos aspectos patrimoniais específícos dos direitos autorais (art. 5. ${ }^{\circ}$, XVII e XVIII), passa a atritar com as garantias fundamentais do direito à liberdade de expressão (art. 5. ${ }^{\circ}$, IX); do direito de acesso à informação (art. 5. ${ }^{\circ}$, XIV); do direito à privacidade (art. 5. ${ }^{\circ}, \mathrm{X}$ ), além do direito à Cultura (art. 215 e segs); ao desenvolvimento, pesquisa científica e capacitação tecnológica (art. 218 e segs.); à manifestação do pensamento, à criação, à expressão e à informação (art. 220 e segs.).

Em se tratando de DRM, se aqueles que os utilizam o fizerem com responsabilidade, sob a observância dos limites impostos pela mesma disciplina que confere os direitos e não

490 DE MATTIA, O autor e o editor..., p. 15.

491 LDA, "Art. 89. As normas relativas aos direitos de autor aplicam-se, no que couber, aos direitos dos artistas intérpretes ou executantes, dos produtores fonográficos e das empresas de radiodifusão.

Parágrafo único. A proteção desta Lei aos direitos previstos neste artigo deixa intactas e não afeta as garantias asseguradas aos autores das obras literárias, artísticas ou científicas." 
praticando o abuso de poder contratual em relação aos usuários, seu uso acaba por se justificar, como mecanismo assecuratório de direitos que se revela eficaz.

Mas tal opção parece utópica, na medida em que, conforme visto nos capítulos anteriores, a indústria fonográfica, até o momento quase a única titular dos direitos autorais, historicamente demonstrou que sua preocupação primordial não é com o público consumidor, de modo que não é crível uma mudança radical de concepção.

Surge, em decorrência, a potencial periculosidade dos DRMs que, mediante o processo de "contratualização" do regime de limites previstos na lei, arrisca violar direitos fundamentais de terceiros ${ }^{492}$. Diante disso, além do evidente dano ao usuário-consumidor de músicas, a própria justificativa autoral estará prejudicada, pelos riscos que a intrusa proteção normativa que a lei confere aos DRMs traz ao próprio direito autoral.

Talvez por justamente prever a derrocada não somente dos mecanismos de DRM quanto do próprio direito autoral mediante o modelo de negócios atualmente executado pela indústria fonográfica ${ }^{493}$ e, conseqüentemente, vislumbrando a possibilidade de prejuízos é que Steve Jobs passou a abertamente criticar a postura contraditória das quatro maiores gravadoras (majors) em relação às exigências de dispositivos técnicos de proteção e gestão, não requeridos para os 20 bilhões de canções vendidas em 2006 pelo mercado tradicional (físico), mas exigidos para os 2 bilhões de canções vendidas no mesmo período pela internet ${ }^{494}$.

492 "Emerge allora la potenziale pericolosità di quei DRMs che, rendendo concretamente attuabile il processo di 'contratualizzazione' del regime delle eccezioni previsto a livello legislativo, rischiano di violare i diritti fondamentali dei terzi." (GHIDINI e MONTAGNANI, Esercizio del diritto..., p.131).

493 Para Pamela Samuelson os titulares de direitos autorais pretendem impor ao consumidor o que deve ser consumido e, agora, com o DRM, a estrita forma sob a qual deve ser consumido, sob o argumento de barrar a pirataria: "the main goal of DRM mandates is not, as the industry often claims, to stop 'piracy' but to change consumer expectations. In the content industry's view, consumers don't have rights; they have expectations. Consumers may not like DRM systems, but if 'legitimate' content is available only on this basis, they'll get used to it" (SAMUELSON, DRM \{AND, OR, VS.\} THE LAW, p.44).

494 "In 2006, under 2 billion DRM-protected songs were sold worldwide by on-line stores, while over 20 billion songs were sold completely DRM-free and unprotected on CDs by the music companies themselves. The music companies sell the vast majority of their music DRM-free, and show no signs of changing this behavior, since the overwhelming majority of their revenues depend on selling CDs which must play in CD players that support no DRM system." (JOBS, Thoughts on music). 
Com efeito, isso é sintomático e motivou a sua defesa à integral abolição dos DRMs ${ }^{495}$ :

\begin{abstract}
A terceira alternativa é abolir integralmente os DRMs. Imagine um mundo onde cada loja on-line vende música livre de DRM codificada em formatos licenciáveis abertos. Neste mundo, qualquer aparelho poderá executar música comprada de qualquer loja, e qualquer loja poderá vender música que seja executada em todos os aparelhos. Esta é claramente a melhor alternativa para os consumidores e a Apple a abraçaria num piscar de olhos. Se as quatro grandes companhias de música licenciassem à Apple suas músicas sem a exigência de que estejam protegidas por DRM, nós passaríamos a apenas vender músicas livres de DRM em nossa loja iTunes. Cada iPod já fabricado irá executar essa música livre de DRM.

Por que deveriam as quatro grandes companhias de música concordar em deixar a Apple e outros distribuírem sua música sem os sistemas de DRM para protegêla? A resposta mais simples é porque DRMs não funcionaram, e provavelmente nunca funcionarão para deter a pirataria musical.
\end{abstract}

Os argumentos do executivo da Apple parecem ter sensibilizado uma das quatro majors, a EMI, a qual oferecia suas músicas somente com a proteção conferida pelo DRM e decidiu também oferecê-las livres de tal dispositivo. Em comunicado conjunto de 2 de abril de 2007, os presidentes de ambas as empresas informaram que o iTunes iniciaria tal nova forma de comercialização, com um acréscimo no valor da música.

Hoje, o usuário estrangeiro que quiser adquirir o direito de armazenar e escutar uma faixa musical com o DRM desembolsa a quantia de 0,99 centavos de dólar estadunidense, enquanto quem prefere sem o dispositivo técnico de proteção paga 1,29 dólares estadunidenses, com a diferença que, no segundo caso, a qualidade de gravação é superior à do primeiro.

A tendência é que, a partir do movimento da EMI, as outras grandes gravadoras sigam o mesmo caminho e também passem a oferecer as suas músicas sem o DRM. No segmento dos distribuidores digitais de música a Amazon informou, em agosto de 2007

495 "The third alternative is to abolish DRMs entirely. Imagine a world where every on-line store sells DRM-free music encoded in open licensable formats. In such a world, any player can play music purchased from any store, and any store can sell music which is playable on all players. This is clearly the best alternative for consumers, and Apple would embrace it in a heartbeat. If the big four music companies would license Apple their music without the requirement that it be protected with a DRM, we would switch to selling only DRM-free music on our iTunes store. Every iPod ever made will play this DRM-free music. Why would the big four music companies agree to let Apple and others distribute their music without using DRM systems to protect it? The simplest answer is because DRMs haven't worked, and may never work, to halt music piracy." (JOBS, Thoughts on music). 
que, na esteira do iTunes, lançaria um sítio para venda de músicas digitais sem mecanismos de proteção ${ }^{496}$, o que foi feito em final de setembro do mesmo ano ${ }^{497}$.

$\mathrm{Na}$ prática, os DRMs acabam por levantar questão concorrencial, uma vez que diversos padrões foram instituídos pelos centros de pesquisa e empresas desenvolvedoras de sistemas informáticos, os quais são adotados por diferentes titulares de direitos e comerciantes de música digital.

A Apple oferece no iTunes formato que é compatível com os iPods, aparelho que somente a própria empresa vende. O formato AAC, por ela utilizado, é "aberto", ou seja, pode ser utilizado gratuitamente por aqueles que desejarem comprimir suas músicas por esse formato. Já os titulares da patente (que são vários) requerem o pagamento de royalties por parte dos fabricantes de equipamentos que desejarem se utilizar da tecnologia.

Tal tecnologia de compressão, uma evolução do MP3, possibilita tanto a utilização de músicas com DRM quanto sem DRM. A Apple, então, pelo sistema "FairPlay" inclui os requisitos de licenciamento exigidos pelas gravadoras ${ }^{498}$, sendo que ela não oferece tais serviços a terceiros interessados a utilizá-los.

Já a Microsoft, além de utilizar o sistema "Windows Media DRM"499, também o oferece para quem deseja assegurar o conteúdo de suas músicas, desde que estejam sob o formato .wma, da própria Microsoft. O software que possibilitará a audição das músicas, quer seja no computador, quer no dispositivo musical portátil deverá ser o "Windows Media Player". Tal serviço é o utilizado pelas lojas brasileiras.

A crítica se dá em relação à dificuldade ou impossibilidade de interoperabilidade entre músicas em determinado formato com aparelhos leitores portáteis que operem em

496 Cf. agência France Presse, NY, em reportagem da Folha de S. Paulo de 17 maio 2007, Caderno Informática. Disponível em: <http://www1.folha.uol.com.br/folha/informatica/ult124u22070.shtml >. Acesso em: 24 ago. 2007.

497 Vide MORAES e SILVA, Amazon começa..., p.L3.

498 Para aprofundamento no tema, vide DILGER, Daniel Eran. How FairPlay Works: Apple's iTunes DRM Dilemma. RouglyDrafted Magazine, 26 fev. 2007. Disponível em: <http://www.roughlydrafted.com/ RD/RDM.Tech.Q1.07/2A351C60-A4E5-4764-A083-FF8610E66A46.html>. Acesso em: 24 ago. 2007.

499 Disponível em: <http://www.microsoft.com/windows/windowsmedia/forpros/drm/default.mspx>. Acesso em: 24 ago. 2007. 
outro $^{500}$ : as músicas baixadas a partir de uma loja que ofereça a música no formato .wma não poderão ser escutadas em um iPod, por exemplo ${ }^{501}$.

A tendência, entretanto, é que, embora seja improvável a adoção de um padrão único, os aparelhos leitores portáteis passem a possibilitar a execução de músicas na maior parte dos formatos existentes ${ }^{502}$, o que, mesmo que aparentemente simples, por depender basicamente do licenciamento da tecnologia pelos fabricantes dos artefatos, adentra em aspectos da estratégia comercial e concorrencial das empresas. Ainda, outra possibilidade concreta é que as gravadoras, na medida em que desenvolvam novos meios de auferirem receitas, eliminem os mecanismos de proteção, ao menos no que se referem ao bloqueio de acesso aos arquivos, que consiste na variante mais impopular dos DRMs.

\subsection{PROPOSTAS VISANDO À CONFORMAÇÃO DOS INTERESSES EM JOGO}

A título de introdução sobre o estado das artes na temática dos direitos autorais, interessante a leitura das palavras do Ministro de Estado da Cultura Gilberto Gil, músico e compositor, que em 11 de novembro de $2007 \mathrm{fez}$ publicar artigo de sua autoria intitulado "Por uma reforma da Lei do Direito Autoral" no Jornal "O Globo". É o texto, na íntegra ${ }^{503}$.

O impacto que as novas tecnologias e o avanço das redes digitais têm causado
sobre o Direito Autoral é reconhecido em todo o planeta. Os limites da legislação
autoral brasileira ficam mais claros com a novidade digital, mas seus problemas
são anteriores ao surgimento da internet. A necessidade de fortalecer o papel do
Estado na resolução de desequilíbrios nesse setor estratégico vem crescendo na
medida em que a legislação envelhece e os desafios se apresentam.
A dinâmica tecnológica deve-nos levar a uma discussão mais estratégica: a
necessidade de uma política nacional para os direitos autorais. Como combinar,

500 Meglena Kuneva, Comissária da União Européia para a Proteção ao Consumidor, em entrevista, demonstrou-se indignada com a ausência de interoperabilidade entre os sistemas de DRM, ao afirmar: "você acha que tudo bem um CD tocar em qualquer tocador de CD, mas uma música do iTunes tocar apenas no iPod? Eu não. Alguma coisa tem que mudar" (HASLAM, Karen. Comissária da União Européia critica vinculação de iPod e iTunes. Matéria jornalística publicada no IDGNOW, 12 mar. 2007. Disponível em: <http://idgnow.uol.com.br/computacao_pessoal/2007/03/12/idgnoticia.2007-0312.0627774807/>. Acesso em: 24 ago. 2007).

501 Vide o já mencionado caso dos sítios nacionais de venda de música on-line que ensinam como "burlar" os próprios mecanismos de DRM.

502 O Digital Audio Player Zune, da Microsoft, lançado no final de 2006, oferece a leitura dos principais formatos de áudio e vídeo.

503 GIL, Gilberto. Por uma reforma da lei do direito autoral. O Globo, Rio de Janeiro, 11 out. 2007, Segundo Caderno, p.4. 
nesse novo contexto, a legítima proteção aos autores e as inúmeras oportunidades da convergência tecnológica? Como favorecer um sistema nacional de propriedade intelectual moderno, equilibrado e justo face à enorme demanda cultural do país? Como promover uma sociedade menos desigual no acesso à cultura e ao conhecimento? O debate foi suscitado porque o Ministério da Cultura recuperou seu papel de articular a política cultural autoral, na busca do necessário equilíbrio que os direitos conferidos aos criadores devem ter com os direitos dos cidadãos brasileiros de acesso à cultura e ao conhecimento, bem como com o direito daqueles que investem na cultura, os chamados "investidores culturais".

O Brasil ainda não consolidou seu marco autoral na proteção aos criadores, que ficam fragilizados nos contratos que lhes são impostos. O modelo regulatório autoral deve buscar garantir aos criadores o legítimo retorno pelo bem-estar que propiciam à sociedade. Entretanto ainda são muitos os desequilíbrios: a diferença de poder econômico entre criadores e investidores; a perda de controle das obras pelos seus próprios criadores; a insatisfação geral com a repartição das receitas e benefícios. O poder público deve promover a maior transparência na gestão das entidades arrecadadoras, apoiar a modernização da gestão coletiva (feita sempre por entidades brasileiras) e desenvolver outros meios de produção e repartição dos benefícios econômicos a partir de obras protegidas por direito autoral. Alguns defendem o uso dos DRMs - software para inviabilizar cópias de arquivos - como forma de proteger autores de cópias não autorizadas na internet. São soluções ineficientes, onerosas e com crescente rejeição nos países desenvolvidos. Além disso, restringem a inovação tecnológica e os direitos básicos dos cidadãos para reproduzir obras com fins legítimos.

Nossa lei não diferencia cópia comercial de cópia privada: ao copiar um arquivo para um tocador de MP3 estamos, todos, cometendo uma ilegalidade. No Brasil, o que temos de parecido com o mecanismo legal norte-americano de "uso justo" de obras protegidas é bastante limitado. Boa parte dos estudantes brasileiros comete ilegalidade ao produzir cópias de livros para sua formação educacional. O monopólio que foi concedido para o autor em relação à sua criação foi uma conquista histórica, mas teve a sua contrapartida nas cláusulas de limitações e exceções, que permitem a cópia de trechos de obras audiovisuais, de um livro, ou mesmo de uma música, sem que isso signifique uma violação do direito de autor. Essas cláusulas, no Brasil, estão entre as mais restritivas do mundo.

Por isso, precisamos debater a modernização do sistema legal e o fortalecimento do poder público na supervisão e na promoção desses vários equilíbrios. A presença do Estado na seara autoral nesses moldes é o que ocorre na imensa maioria dos países do mundo. Nesse sentido, o Ministério da Cultura - e diversos parlamentares ligados ao tema - está empenhado em promover a mais ampla discussão que vai embasar a atualização da lei. O I Fórum Nacional de Direitos Autorais será realizado em 2008, envolvendo autores, entidades, empresários e sociedade civil.

Sozinho, o poder público não pode implementar uma estratégia ampla para o setor. Há um grande desafio de inovação para o setor cultural. O modelo do Creative Commons não é uma política de Estado e nem uma iniciativa inventada pelo MinC, mas um movimento cultural mundial relevante, onde os autores, conscientes de seus direitos, distinguem usos com finalidades comerciais e não comerciais. Aproveitam ao máximo o potencial de divulgação da convergência tecnológica e se beneficiam dela. Tais licenças alternativas não resolvem todos os problemas da área autoral e podem não se adequar a todos os criadores, como, por exemplo, o compositor que não é intérprete. Para eles, naturalmente, é preciso resguardar a utilização das ferramentas tradicionais do direito autoral. No entanto, para aqueles que se iniciam na área cultural tais licenças podem ser benéficas na construção de suas carreiras.

O Ministério da Cultura participa com outros ministérios na política de combate ao crime organizado, e aos núcleos que lideram a organização da pirataria no Brasil. Combinada à repressão, o governo tem dado grande ênfase a medidas educacionais, econômicas e de combate à desigualdade. O desafio é trazer para a formalidade a distribuição de bens culturais, gerando emprego e renda. 
São desafios dos séculos XX e XXI. Sem perder tempo, o Brasil investe hoje na infra-estrutura material (estradas, energia e portos, através do PAC) e nas políticas estratégicas para um genuíno salto e reposicionamento na cultura, na tecnologia, na sociedade do conhecimento. Acreditamos que uma legislação autoral equilibrada e moderna é condição para esse salto - assim como um Ministério da Cultura fortalecido na gestão dessa política. Podemos dizer que o edifício autoral poderá novamente erigir-se. Reformas como essa são mais do que necessárias, são inevitáveis.

Com efeito, o texto de Gilberto Gil traz resumo da situação atual e expressa o aparente conflito entre o direito autoral e direito de acesso aos bens culturais, mormente ao apresentar o tríplice questionamento: "Como combinar, nesse novo contexto, a legítima proteção aos autores e as inúmeras oportunidades da convergência tecnológica? Como favorecer um sistema nacional de propriedade intelectual moderno, equilibrado e justo face à enorme demanda cultural do país? Como promover uma sociedade menos desigual no acesso à cultura e ao conhecimento?".

O artigo do Ministro, entretanto, merece reflexão n'alguns pontos: i) a defesa do fortalecimento do papel do Estado na resolução de desequilíbrios na medida do envelhecimento da legislação e surgimento de desafios; ii) o monopólio como fundamento do direito autoral:

i) No primeiro aspecto objeto de reflexão ele defende "a necessidade de fortalecer o papel do Estado na resolução de desequilíbrios nesse setor estratégico vem crescendo na medida em que a legislação envelhece e os desafios se apresentam", apontando-se, no texto, tais desequilíbrios como sendo "a diferença de poder econômico entre criadores e investidores; a perda de controle das obras pelos seus próprios criadores; a insatisfação geral com a repartição das receitas e benefícios".

O Poder Judiciário, quando instado, tem auxiliado na resolução de desequilíbrios nos direitos autorais. É verdade que muitas vezes falta especialização no tema aos julgadores. Demonstra-se válida a intenção de se construir políticas públicas para tal setor, desde que sejam observados critérios razoáveis e que não acabem por prejudicar o destinatário principal da norma autoral: o autor.

A lei autoral brasileira é recentíssima, de 1998. A Constituição Federal é de 1988. É certo que as mudanças e os desafios - mesmo e, principalmente sociais - ocasionados pela internet podem tornar necessários alguns ajustes pontuais, mas certamente se incorre em exagero afirmar que a legislação está envelhecida. Do mesmo modo, a exemplo do que ocorre noutras matérias, o Poder Judiciário deve trazer sua interpretação de forma a atingir 
a justiça ${ }^{504}$, não sendo necessária, em princípio, a promoção de profundas mudanças legislativas. O papel de auxiliar os operadores do direito - mormente magistrados - a se especializarem no tema (e que o Ministério da Cultura já afirmou ser um dos meios que utilizará) é significativo dentro da política pública autoral.

Por outro lado, os executores da política hão de manter as necessárias cautela e isenção, até mesmo para preservar o princípio da proporcionalidade, que consiste numa "limitação do poder estatal em benefício da garantia de integridade física e moral dos que lhe estão sub-rogados"505, pelo fato de que os objetivos a serem colimados com o pretendido meio (aumento do poder estatal ao Poder Executivo, conferindo-lhe a prerrogativa da correção dos desequilíbrios) podem vir a conflitar com garantias fundamentais conferidas aos próprios sujeitos os quais pretensamente serão defendidos, enquanto já existe um Poder Judiciário apto a resolver tais desequilíbrios.

ii) Foi aduzida imprecisão no texto ao se afirmar que "o monopólio que foi concedido para o autor em relação à sua criação foi uma conquista histórica", já que o Brasil sempre foi filiado ao sistema do direito de autor latino-germânico.

Embora no próprio texto se verifique menção de caráter nacionalista ${ }^{506}$, é equivocada a análise da questão do direito autoral sob o prisma alienígena do sistema anglo-americano, legítimo sucessor do sistema dos privilégios de impressão ${ }^{507}$, cunhado tão-somente na garantia do retorno do investimento, portanto de caráter patrimonial ${ }^{508}$.

504 Para Willis Santiago Guerra Filho, "O juiz não há de se limitar a ser apenas, como disse Montesquieu, la bouche de la loi, mas sim la bouche du droit, isto é, a boca não só da lei, mas do próprio Direito". Continua, o autor: "Eis o 'paradoxo da transformação da coerção em liberdade', uma vez que o juiz se acha vinculado às leis, mas não à legislação, que é sempre objeto de sua interpretação, inclusive a norma que o vincula à lei, levando em conta textos com autoridade superior como aquele da Constituição." (GUERRA FILHO, Willis Santiago. Teoria processual da constituição. São Paulo: Celso Bastos Editor: Instituto Brasileiro de Direito Constitucional, 2000. p.89 e 91).

505 GUERRA FILHO, Teoria processual..., p.75.

506 P.ex.: "O poder público deve promover a maior transparência na gestão das entidades arrecadadoras, apoiar a modernização da gestão coletiva (feita sempre por entidades brasileiras) ...". [grifo nosso].

507 Informa Antônio Chaves que, na época dos privilégios, os "autores e editores não reivindicavam um verdadeiro direito: contentavam-se com a garantia de que, os primeiros a sua produção intelectual, e os segundos, o ingente capital que empregavam na indústria, não sofreriam concorrência, o que conseguiam com o sistema de monopólio" (CHAVES, Direito do autor, p.25)

508 Uma possibilidade é que a confusão tenha ocorrido devido ao fato de que nos países onde se adota o sistema jurídico anglo-saxônico o monopólio é considerado uma forma de propriedade, conforme informa Denis Borges Barbosa: "Nestes países, a noção de propriedade abrange os monopólios legalmente 
A verdadeira conquista histórica é o asseguramento do direito de autor ao criador intelectual, muito mais significativo, em todos os sentidos, do que a mera concessão de monopólio, este sim de caráter eminentemente patrimonial e mercantil.

É certo, entretanto, que o direito de autor está inserido no direito de propriedade ${ }^{509}$, em cujo conteúdo consta o direito de exclusivo, que pode ser entendido como o monopólio.

Outrossim, tal discussão sobre a natureza do direito de autor já teve lugar na história brasileira, há um século, e remetia à sua inserção ou não no direito de propriedade: em

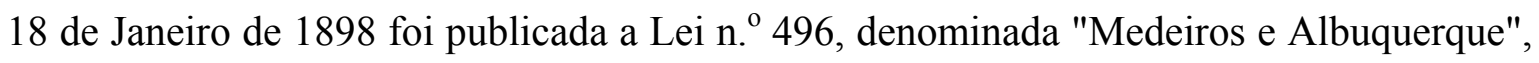
que definia e garantia os direitos autorais; entretanto, ainda considerando-o como um privilégio, como se depreende da oposição veemente à interpretação do direito de autor como propriedade, por parte do congressista autor da lei à qual emprestou seu nome ${ }^{510}$.

Naquele momento histórico da fase de discussões para a formulação do Código Civil, introduzido pela Lei n. ${ }^{\circ} 3.071$ de 1 de janeiro de 1916, apresentou-se intensa polêmica quanto à natureza jurídica do direito de autor, se direito de propriedade ou simples privilégio (acepção de monopólio). O fato é que o Capítulo VI do livro do "Direito das Coisas" foi titulado "Propriedade Literária, Científica e Artística", o que demonstra a adoção da teoria da propriedade.

reconhecidos, como, por exemplo, as concessões de serviço público, e é tão ampla que cobre o espaço reservado, na nossa tradição jurídica, a idéia invento, a sua utilização intelectual, a elaboração de Pesquisas. Enfim, os direito de propriedade tutelam a atividade empresarial do titular do privilégio". (BARBOSA, Denis Borges. A posse e a propriedade na concorrência. Disponível em: $<$ http://www.uj.com.br/publicacoes/doutrinas/default.asp?action=doutrina\&iddoutrina=2956>. Acesso em: 17 nov. 2007).

509 Muito embora tenha aumentado, em setores da doutrina, o entendimento de que é direito sui generis.

510 Informa Carlos Fernando Mathias de Souza que: "Medeiros e Albuquerque, em artigo publicado no Correio da Manhã, em 13 de dezembro de 1901 (quando então em plena discussão o projeto do Código Civil), sob o título 'Os Direitos Autorais no Código Civil', praticamente faz um libelo contra o considerar-se o direito autoral como propriedade e até mesmo com respeito à sua inclusão no Código. Ilustre-se com a transcrição do seguinte trecho: 'Seja como fôr, é pozitivo que a estas horas o conceito jurídico de direito autoral ainda não está firmado; todas as lejislações, com somente as ridículas exceções apontadas, o consideram privilégio' (de passagem, consigne-se que aqui o autor fez uma crítica a Clóvis Beviláqua e às legislações do México, Guatemala e Venezuela). 'Mesmo algumas que o chamam 'propriedade' fazem dela uma propriedade 'sui generis', tranzitória, sujeita a regras especiais, regras que, dezacordo com o nome lhe tiram todo o caráter de propriedade. Desde, porém que os escritores empregam a locução 'sui generis' e dizem que se trata de uma propriedade de natureza especial, julgam-se no direito de subtrair muitos dos característicos essenciais do que todos sempre entenderam pela expressão propriedade. E fica a couza reduzida a uma pura logomaqnia." (SOUZA, Carlos Fernando Mathias de. Informativo jurídico "O neófito". Disponível em: <http://www.neofito.com.br/artigos/art01/civil57.htm>. Acesso em: 4 jun. 2006). 
A esse respeito, posteriormente esclareceu J.M. de Carvalho Santos:

\begin{abstract}
A respeito da natureza do direito autoral e sua classificação é renhida a controvérsia doutrinária, mas o nosso Código não hesitou em considerá-lo como propriedade sui generis, aliás acompanhando a orientação que lhe estava delineada pela própria Constituição Federal, no seu art. 113, n. 20 ao dispor: "Aos autores de obras literárias, artísticas e científicas é assegurado o direito exclusivo de reproduzí-las. Esse direito transmitir-se-á aos seus herdeiros pelo tempo que a lei determinar". De fato, o que a Constituição garante é o direito exclusivo a reproduzir a obra, ou seja, o direito exclusivo sobre a obra literária, científica ou artística, ou ainda, mais precisamente, é o direito exclusivo sobre a coisa. Ora o direito exclusivo sobre a coisa que está no patrimônio de alguém, é justamente o direito de propriedade..$^{511}$
\end{abstract}

Decorre que, a partir dessa concepção, os produtos da criação do espírito, bens imateriais que pela norma atual são igualados para fins legais aos bens móveis ${ }^{512}$, podem ser considerados como uma das formas mais puras de propriedade ${ }^{513}$. Foi, a partir disso, construída a teoria do direito de autor "continental" ou "latino-germânico", pautada de modo precípuo na proteção do indivíduo criador, cuja personalidade apresenta liame indissociável à sua obra.

Tal concepção de propriedade, de caráter individualista, serviu como base e foi adotada pelo Código Civil Francês e pelas codificações subseqüentes filiadas a tal sistema e refletia "a ideologia da filosofia liberal que lançou as bases da construção moderna do

511 SANTOS, J. M. de Carvalho, Código civil..., p.403-404.

512 Lei n. ${ }^{\circ}$ 9.610/1998, "Art. 3. ${ }^{\circ}$ Os direitos autorais reputam-se, para os efeitos legais, bens móveis."

513 "Seguindo, no essencial, a inventariação de Pierre Recht, ele próprio autor de uma tese original que denomina 'propriedade-criação', as orientações clássicas que têm animado o debate são, sumariamente: da doutrina da propriedade intelectual de Pouillet (Traité théorique et pratique de la propriété littéraire et artistique, 1879); a teoria personalista ou do direito de personalidade de Gierke (Deutsches Privatrecht, I, 1895); a tese do Dopelrecht (real e pessoal) de Kohler (Urheberrecht na Schriftwerken, 1907); a teoria dos direitos intelectuais ou direitos de exclusivo de Edmound Picard (Le Droit Pur, 1899), a teoria do monopólio de Ernest Roguin (La règle de droit, 1899) e a concepção dos direitos de clientela, também chamados intelectuais, de Roubier ( $R d c$ 1935, p.285), desenvolvidos por Desbois (Le droit d'auter, 1950); a teoria dos direitos sobre bens imateriais de Greco (I diritti sui beni immateriali, 1948); as teses dualistas de Piola Caselli (Tratatto del diritto di autore e del contratto di edizione, 2. , 1927), Plaisant (Propriété littéraire et artistique, 1954), De Sanctis (La nature juridique du droit d'auter, 1962) e Le Tarnec (Manuel de la propriété littéraire et artistique, 2ed. 1966) e o conceito dos 'direitos paralelos' de Savatier (Métamorphoses, 1959); o minismo germânico de De Boor e de Ulmer (Urheberund Verlgasrecht, 1951), com a abertura 'à propriedade espiritual (geistiges Eigentum) de Heinrich Hubmann (Das Recht des schopferischen Geistes, 1954)". (PEREIRA, Informática, direito..., p.115). 
direito privado, solidificando-se como um pressuposto para a garantia da liberdade dos indivíduos"514. [grifos do autor]

Em síntese, não se deve confundir o direito de autor com simples monopólio, equívoco presente na percepção geral acerca do tema, o que não se restringe aos leigos, mas também acomete parcela da doutrina. É o que informa José de Oliveira Ascensão, sobre a questão musical como um todo: "permitimo-nos sugerir que há um défice de aprofundamento jurídico do problema nos países do sistema romanístico do Direito, porque se tem dominantemente retomado a equação norte-americana da questão e esta, porque fundada no fair use, não é válida nos nossos ordenamentos"515.

O texto, ainda, considera a legislação autoral defasada e se apressa em condicionar a alterações normativas o sucesso de política pública a ser implementada pelo Ministério da Cultura. É certo que o Poder Público, mormente o Poder Executivo, mediante o Ministério da Cultura, deve apoiar o processo criativo por meio da execução de bem-elaboradas políticas públicas, mas também é certo que não pode fazer isso em detrimento das garantias conquistadas a duras penas pelos autores que, conforme reconhece o texto, sempre foram a parte hipossuficiente em relação ao investidor cultural.

Pior que isso é se passassem a ser hipossuficientes em relação ao Poder Público, verdadeiro monstro paquidérmico conduzido sob cores ideológicas. A legislação autoral brasileira é extremamente protetiva ao autor, em nível muito mais eficaz do que a legislação do sistema do copyright, da qual parece o ministro ter tirado o fundamento para seu entendimento acerca do tema. Realmente, o autor acaba por ser, muitas vezes, lesado em contratos firmados com investidores-capitalistas, mas tal desequilíbrio deve, em primeira análise, ser decidido pelo Poder Judiciário.

Com efeito, poder-se-ia alegar que é caso de política pública o incentivo ao fortalecimento do autor, para que possa fazer frente ao investidor ao contratar. Mas não se olvide que com os mecanismos que a tecnologia oferece, justamente como está sendo visto no presente estudo, os compositores e os intérpretes já podem conquistar seu espaço perante o público sem qualquer ou pouco investimento. Sem o envolvimento do Estado, que ao se

514 LEONARDO, Rodrigo Xavier. A função social da propriedade: em busca de uma contextualização entre a Constituição Federal e o Novo Código Civil. Revista da Faculdade de Direito de São Bernardo do Campo, ano 8, n.10, p.272, 2004.

515 ASCENSÃO, Aspectos jurídicos..., p.86. 
mover o faz mediante custos altíssimos, cujo ônus é sempre do cidadão-contribuinte. $\mathrm{O}$ importante é que o autor tenha a defesa incondicional de seus direitos assegurada, sem depender do beneplácito estatal conforme no sistema de monopólios.

Daí é que se deve refletir sobre o papel do Estado nesse setor. Guilherme Carboni, em sua obra originariamente defendida como tese de doutorado perante a Faculdade de Direito da USP, traz reflexões de lume:

\begin{abstract}
Se, no mundo globalizado, uma das considerações sobre o modo das políticas culturais é a garantia da possibilidade de um maior número possível de pessoas participar do processo cultural na qualidade de criadores, a estrutura do sistema do direito de autor tem de ser construída de forma a incentivar e não, a inibir esse processo.

No entanto, o problema de saber o quê o Estado deve incentivar por meio de políticas culturais (tendo em vista que os valores culturais de um país que se desbastam e se multiplicam na sociedade), não diz respeito ao direito de autor, que apenas privilegia o criador de obras intelectuais, independentemente de seu valor cultural para o país.

Por essa razão é que o direito de autor, enquanto instrumento que tem por função promover o desenvolvimento cultural, econômico e tecnológico, deve ser entendido como uma política de liberalismo cultural, pois, apesar de imposta pelo Estado, a proteção autoral recai sobre todas e quaisquer obras intelectuais que atenderem aos requisitos legais, sem qualquer juízo de valor, o que é bastante louvável. Se assim não fosse, cairíamos em uma situação de o Estado ditar as obras protegidas de acordo com o interesse nacional, o que só se justificaria em rgimes totalitários. ${ }^{516}$
\end{abstract}

Por fim, a iniciativa do Ministro em conclamar a população e os envolvidos ao debate se demonstra positiva, porque os desafios que são apresentados pelas novas tecnologias são efetivamente complexos ${ }^{517}$. Entretanto, é de se esperar a isenção do órgão que dirige na condução dos mesmos e, principalmente, o aprimoramento da técnica jurídica no sentido de se evitar armadilhas, a exemplo da confusão entre os sistemas protetivos dos direitos autorais, para que não sejam importados do estrangeiro problemas e concepções que não nos dizem respeito.

Outrossim, a julgar pelo discurso do Ministro no Seminário de Lançamento do Fórum Nacional de Direito Autoral 2007/2008, em 5 de dezembro de 2007, parece ter sido um pouco amenizado o ímpeto constante do artigo publicado em novembro. É trecho do

516 CARBONI, Função social..., p.89.

517 Foi, assim, lançado o Fórum Nacional de Direito Autoral 2007/2008, tendo sido programados diversos eventos para que sejam feitos debates entre membros de diferentes categorias: Seminário de Lançamento, Seminário sobre gestão coletiva, Seminário para acadêmicos e autoralistas, Seminário para artistas e autores, Seminário para usuários e consumidores de obras protegidas, Seminário sobre novas tecnologias e Seminário internacional sobre direito autoral. Fonte: Sítio do Fórum Nacional de Direito Autoral 2007/2008 (Disponível em: <http://www.cultura.gov.br/blogs/direitoautoral/?p=10>. Acesso em: 9 dez. 2007. 
discurso, que apresenta mea culpa inclusive em relação a alguns dos pontos analisados nesse tópico do presente estudo ${ }^{518}$ :

\begin{abstract}
É preciso discutir o papel do Estado para enfrentar esses desequilíbrios, sua capacidade de formulação e implementação da política autoral. Para podermos ter uma visão conjunta mais adequada dos desafios que temos pela frente e do que precisamos fazer, iniciaremos aqui, hoje, essa série de consultas aos diversos grupos culturais e cidadãos de várias localidades do país. O Ministério da Cultura traz sua visão inicial baseada na experiência de quem lida no dia-a-dia com o tema. No entanto, é preciso, antes de mais nada, discutirmos fora dos gabinetes, envolvendo todo o setor cultural na construção desta política. São perguntas que precisamos responder coletivamente. Em que medida é preciso alterar a Lei? Já vi muitas manifestações, através da mídia e de outros meios, no sentido de que não se faça mudanças na lei, isso deve ser discutido aqui neste Fórum, por exemplo. Até que ponto é preciso reforçar o papel do Estado na área? Tenho a impressão de que é do reconhecimento de todos que o desaparecimento do Conselho Nacional do Direito Autoral tenha deixado uma lacuna e que hoje o Estado Brasileiro precisa estar atento a questões como essa. É preciso encontrar mecanismos mais efetivos de proteção e retribuição ao autor? Sobre algumas destas questões o governo gostaria de colher as mais diversas propostas nesses Seminários e Oficinas.
\end{abstract}

Espera-se que essa visão ponderada prevaleça no decorrer do Fórum e que efetivamente as alterações legislativas se façam de maneira ponderada, isentas de conotação ideológica.

\title{
3.3.1 Breve Análise das Propostas em Face dos Desafios Impostos pela Evolução Tecnológica
}

No primeiro capítulo foram analisadas as diversas crises pelas quais atravessou o direito autoral, no que se refere à música, com o que foi possível a percepção de que a cada nova tecnologia que surgia os sujeitos inseridos no contexto dos direitos autorais se alarmavam, decretando a falência do sistema autoral e a necessidade de mudanças radicais.

Entretanto, réquiens à parte ${ }^{519}$, o direito autoral foi sendo objeto de adequações naquilo que se fazia necessário, até que sobreveio a atual crise, que foi objeto de análise no segundo capítulo deste estudo. A tendência é de sempre a crise atual ser considerada a pior, a mais letal de todas. E a presente crise não foge à regra.

518 Disponível em: <http:/www.cultura.gov.br/blogs/direito_autoral/?p=11\#more-11>. Acesso em: 9 dez. 2007.

519 "Por outro lado, não falta quem anuncie a diluição do direito de autor num direito genérico da informação e, mesmo, a 'morte' do direito de autor." (PEREIRA, Informática, direito..., p.38). 
O que mudou, entretanto, foi que com as experiências tidas nas crises passadas, o legislador, mormente o internacional, aquele que delineia os contornos do direito autoral, passou a prudentemente elaborar os artigos na forma exemplificativa, como normas em aberto, tornando o instrumento legal amoldável às situações futuras.

E é exatamente isso que ocorre na lei autoral brasileira, adequada a todos os modernos tratados internacionais sobre a matéria e vinculada ao sistema de direito de autor latino-germânico, aquele que mais proteção efetiva oferece ao autor-criador.

Outrossim, se no plano normativo o autor se encontra devidamente protegido, revela-se dissonância no que diz respeito aos atuais hábitos sociais em relação ao imperativo legal, já que com o advento da internet os usuários passaram a ter contato muito facilitado com as obras musicais, o que pode ser positivo de um lado mas negativo de outro, uma vez que também criaram o hábito de não efetuar dispêndios em contrapartida.

Nesse cenário é que se revela a crise atual: os usuários pretendem ter acesso gratuito a farto material musical pela internet, compositores e investidores musicais pretendem ser remunerados e intérpretes estão divididos, normalmente entre aqueles que estão em início de carreira ou não atingiram ao menos médio nível de êxito e reconhecimento e tanto lhes faz receber ou não, desde que suas interpretações sejam disseminadas e, de outro lado, em muito menor número, artistas já com certo reconhecimento e que pretendem ser remunerados pela utilização de suas músicas por qualquer meio, inclusive a internet.

Esse é o aspecto primário e pano de fundo da crise: o conflito entre os direitos autorais e o direito de acesso aos bens culturais.

Outrossim, as propostas de solução para os desafios apresentados nos direitos autorais na música podem ser divididas em dois distintos grupos: i) as mais radicais, que demandam mudança conceitual e legislativa, e ii) as propostas que foram elaboradas sob o reconhecimento da contratualização - ou privatização - dos direitos autorais, fenômeno mundial que vem tomando força nas legislações autorais das últimas décadas e, sob as mesmas premissas, visam promover meios de equalizar todos os interesses em jogo.

i) São, dentre outras, exemplos de propostas de solução que demandam a mudança conceitual e (ou) legislativa: (a) a ruptura com o sistema atual de direitos autorais; (b) o licenciamento compulsório; (c) a instituição de cobrança de tarifa para meios físicos virgens, respectivos aparelhos gravadores e aparelhos reprodutores de MP3 ou outros formatos existentes. 
a) A proposta de ruptura com o sistema atual de direitos autorais demanda profundas alterações legislativas, mormente pelo fato de que a grande maioria dos países faz parte de tratados internacionais que versam sobre a adoção interna de parâmetros mínimos de proteção aos direitos autorais, de modo que teriam de ser antes denunciados para que, de forma localizada, um país alterasse sua respectiva legislação.

Essa proposta contém nítida conotação ideológica. Seus partidários questionam não somente a inserção dos direitos autorais no direito da propriedade, mas também o fato de o autor utilizar em seu processo criativo o substrato comum e depois com o resultado auferir lucro, o que consideram injusto, já que consistiria numa forma de impedir o acesso da coletividade a algo que teria sido elaborado com fontes comuns. Alegam, ainda, que os reais titulares de direitos autorais são grandes corporações transnacionais, ao invés dos autores que a lei deveria proteger.

Aduzem que o impacto causado pelos avanços tecnológicos fulminou o direito autoral tradicional e que o hábito de utilizar a internet livremente para o acesso à música e demais bens culturais - já está sedimentado.

Corroborando a constatação do aspecto ideológico, no início de 2006 foi constituído, na Suécia, o partido político Pirate Partiet ${ }^{520}$, que no mesmo ano concorreu às eleições ao parlamento daquele país, ocasião em que não elegeu representante, mas se organizou e tornou suas plataformas visíveis à população sueca. Tal iniciativa teve ampla repercussão mundial, pelo destaque que recebeu da mídia.

Em conseqüência, ativistas de diversos países estão se movimentando para constituir partidos políticos similares, já dispondo de sítios próprios na internet ${ }^{521}$, além de um sítio denominado PPInternational ${ }^{522}$, em que se objetiva congregar o "movimento pirata" do mundo todo. Em visita a tal sítio toma-se conhecimento dos países onde "partidos piratas" estão sendo formados, inclusive o Brasil ${ }^{523}$.

520 Disponível em: <http://www.piratpartiet.se/international/english>. Acesso em: 25 nov. 2007.

521 Note-se que não necessariamente constituídos na forma legal como partidos políticos. Relação dos sítios disponível em: <http://www.piratpartiet.se/international>. Acesso em: 25 nov. 2007.

522 Disponível em: <http://www.pp-international.net/>. Acesso em: 25 nov. 2007.

523 Disponível em: <http://www.pp-international.net/forum/viewtopic.php?t=1028\&sid=3e6f2915a3a74019 db0fdbf4530d0a4a. Acesso em: 25 nov. 2007. 
São três os objetivos do Partido Pirata: a reforma da legislação autoral, a abolição do sistema de patentes e o respeito ao direito de privacidade. O primeiro deles refere-se diretamente ao tema do presente estudo, enquanto o terceiro tem vinculação indireta, na medida em que a privacidade on-line é relativizada pelos sistemas de gestão de direitos (DRMs), bem como pela identificação de usuários de redes $P 2 P$ por meio de mecanismos tecnológicos.

Conforme consta do sítio do partido sueco ${ }^{524}$, a pretendida reforma do sistema de direito autoral busca re-equilibrar os interesses envolvidos, pelo fato de que atualmente as legislações autorais restringem aquilo que supostamente deveriam promover (a criação da cultura e sua disseminação).

Em conseqüência são propostos: que todas as cópias e utilizações com intuito nãocomercial sejam livres, assim como o compartilhamento de arquivos e redes P2P sejam encorajados ao invés de criminalizados; que o prazo de proteção concedido a um titular de direitos autorais para utilização comercial seja limitado a cinco anos após a publicação; que sejam banidas as tecnologias de gestão de direitos digitais (DRMs) e quaisquer cláusulas contratuais que restrinjam direitos de consumidores.

É interessante notar que tais bandeiras são similares àquelas exibidas no artigo publicado pelo Ministro Gilberto Gil para justificar o início do ciclo de debates que o Ministério da Cultura promoverá nos anos de 2007 e 2008.

Na proposta ora sob verificação, o ponto de partida é a premissa da existência de desequilíbrio entre os direitos autorais assegurados aos respectivos titulares e o direito de

524 "The official aim of the copyright system has always been to find a balance between the interests of publishers and consumers, in order to promote culture being created and spread. Today that balance has been completely lost, to a point where the copyright laws severely restrict the very thing they are supposed to promote. The Pirate Party wants to restore the balance in the copyright legislation.

All non-commercial copying and use should be completely free. File sharing and p2p networking should be encouraged rather than criminalized. Culture and knowledge are good things, that increase in value the more they are shared. The Internet could become the greatest public library ever created.

The monopoly for the copyright holder to exploit an aesthetic work commercially should be limited to five years after publication. Today's copyright terms are simply absurd. Nobody needs to make money seventy years after he is dead. No film studio or record company bases its investment decisions on the off-chance that the product would be of interest to anyone a hundred years in the future. The commercial life of cultural works is staggeringly short in today's world. If you haven't made your money back in the first one or two years, you never will. A five years copyright term for commercial use is more than enough. Non-commercial use should be free from day one.

We also want a complete ban on DRM technologies, and on contract clauses that aim to restrict the consumers' legal rights in this area. There is no point in restoring balance and reason to the legislation, if at the same time we continue to allow the big media companies to both write and enforce their own arbitrary laws." Disponível em: <http://www.piratpartiet.se/international/english>. Acesso em: 25 nov. 2007. 
acesso aos bens culturais por parte dos consumidores, o que demandaria a reformulação legislativa e a atuação direta do Poder Executivo, por meio de políticas públicas.

Tal "solução" já foi posta em prática noutros tempos, adotada na legislação da antiga União Soviética, e se revelou desastrosa para a produção cultural. É o que Dietrich Loeber constatou em estudo publicado em meados de 1980, portanto ainda na existência da URSS:

\begin{abstract}
Uma importante tarefa para o legislador soviético é atingir o equilíbrio entre os legítimos interesses dos autores e os interesses da 'sociedade'. Enquanto o autor busca almeja ampla proteção contra qualquer uso não-autorizado de sua obra, a sociedade aspira por amplo acesso aos tesouros culturais da terra. De um estado que está construindo o comunismo pode-se esperar que desenvolva 'novos conceitos e relações' para solucionar o conflito de interesses entre o autor e a 'sociedade'. Esses novos conceitos incluem o escopo da proteção pelo direito autoral, $\mathrm{o}$ alcance dos direitos do autor às suas obras e o alcance dos direitos da 'sociedade' a utilizar obras protegidas por direitos autorais. ${ }^{525}$
\end{abstract}

A formulação soviética garantiu ao autor alguns direitos, somente no aspecto moral, sendo que os principais eram aqueles da paternidade e do inédito, além do direito de modificação da obra. Cumpre, entretanto, notar - e isso revela semelhança com o que hoje é defendido pelos partidários dessa proposta em análise - que o direito de modificação deveria ser reconciliado com a regra de que outros autores também poderiam utilizar tal obra ${ }^{526}$.

No aspecto patrimonial não existiam direitos assegurados, havendo tão-somente o pagamento de remuneração pelo trabalho, que podia ser na qualidade de empregado ou free-lancer. Informa Fabio Maria De Mattia que "a retribuição do autor - os honorários -

525 Tradução livre de "One important task for the Soviet legislator is to strike a balance between the legitimate interests of authors and the interests of 'society'. While the author seeks broad protection against unauthorized use of his work, society strives for wide access to the cultural treasures of the land. A state that is building communism can be expected to develop 'new concepts and relationships' for solving the conflict of interests between author and 'society'. These new concepts include the scope of copyright protection, the extent of authors' rights to their works, and the extent of 'society's' rights to use copyrighted works." (LOEBER, Dietrich A. "Socialist" Features of Soviet Copyright Law. Columbia Journal of Transnational Law, n.23, p.298, 1984-1985).

526 Baseado no estudo de Dietrich Loeber, para quem: "Soviet Laws grants authors a number of personal rights. Of basic importance are the rights to authorship and to recognition as the author of a particular work. The right of authorship includes the authority to decide when the work is ready to be disclosed to the public. ... Finally, the author is entitled to adapt and to change his work. This right, however, must be reconciled with the rule that other authors may use that work as well, provided that their work meets the test of 'newness', i.e. that it has the quality of an original, independent creation." (LOEBER, "Socialist" Features..., p.300). 
não depende nem do preço de venda nem do da distribuição da edição ao público"527. Os critérios para a remuneração variavam de acordo com a "importância" do que era produzido, sendo certo que as obras as quais exaltavam a "revolução" ou o caráter superior do socialismo e do comunismo, o Partido Comunista, assim como a vida dos ícones da revolução rendiam aos autores os máximos valores. Cumpre notar, entretanto, que se fosse do entendimento da burocracia que algum autor recebia valor "desproporcional", as obras passavam à titularidade do Estado, pelo que se passava a receber o salário normal.

Por outro lado, os direitos conferidos à "sociedade" eram mais abrangentes e favoreciam a comunidade em detrimento dos autores e se constituam no direito de publicar uma obra, do uso livre, do licenciamento compulsório e da aquisição compulsória ${ }^{528}$.

Com isso se torna perceptível que os fundamentos da proposta de alteração legislativa acabam por, na prática, conduzir a uma situação em que o autor se livra da exploração da indústria fonográfica "capitalista" para então ter que se submeter aos "interesses da sociedade" - esses tomados levando-se em conta o perfil ideológico do governo de plantão -, com isso abrindo mão de conquistas importantes, representadas pelo reconhecimento do direito autoral.

Por outro lado, realmente - e isso foi visto no decorrer do presente estudo - a legislação protetora dos direitos autorais recrudesceu nos últimos tempos. Mas tal recrudescimento, por si só, não justifica a sua profunda alteração.

É perceptível, outrossim, que os defensores de tal proposta olvidam das principais inovações trazidas pela internet - vistas neste estudo -, cuja existência e de seus muitíssimos meios de disseminação de obras autorais inquestionavelmente possibilitou o acesso dos consumidores a uma quantidade imensa de obras musicais. E isso sem a necessidade de qualquer reformulação normativa.

527 DE MATTIA, O autor e o editor..., p.267.

528 "There are four important rights of 'society' that favor the community at the expense of the author and exhibit unconventional features vis-à-vis the capitalist system. These rights involve the right to make a work public, free use, compulsory license and compulsory purchase." (LOEBER, "Socialist" Features..., p.301). Informa o mesmo autor, sobre o direito de publicação que "contrary to a widely-held view in the West, Soviet law has not abolished or limited this right, as long as the author does not exercise the right as a trade or for profit. In practice, the right amounts to the opportunity to duplicate a work in typewritten form since the general public has no access to photocopiers. The author is free to disseminate the typescript among friends, a method known in the Soviet Union as samizdat (self-publishing)". 
Noutras palavras, se antes o consumidor tinha o acesso tão-somente ao que lhe era oferecido pela indústria fonográfica, com o que travava contato por meio das emissoras de radiodifusão - e correspondentes "acertos comerciais para divulgação" -, hoje tem acesso a um número infinitamente superior de obras musicais, cujos autores e intérpretes estão dispostos a tornar disponíveis na internet de forma direta, mediante cobrança ou não.

A partir disso é de questionar o motivo da ampla modificação de uma legislação moderna, que privilegia a autonomia privada do compositor e do intérprete em não contratar com gravadora se assim não o desejar, e que também torna possível a oferta de suas músicas por meio de licenças alternativas, a exemplo do Creative Commons ${ }^{529}$.

É o mesmo exercício da autonomia privada que se espera do usuário de obras musicais. Se pretende ter acesso a obras às quais não haja a necessidade do pagamento de contraprestação, terá multiplicidade de opções. Por outro lado, se ele pretende utilizar músicas de compositores, artistas ou gravadoras que optem pela cobrança de contraprestação, que esteja disposto a pagá-la.

É simples. Consiste no reconhecimento de que a própria evolução tecnológica fez surgir um cenário muito mais interessante a todos os sujeitos. O acesso às obras musicais é extremamente facilitado. Se antes o número de artistas e compositores vinculados a uma gravadora major era calculado na ordem de centenas, hoje são milhões deles espalhados pelo mundo e tornados acessíveis pela internet, grande parte oferecendo sua arte sem a cobrança de contraprestação.

Com efeito, em vista do que já foi objeto de análise no presente estudo, mister ressaltar que o modelo de cobrança atualmente adotado pelas grandes gravadoras, ao que parece, não terá maior tempo de sobrevida. Mas nem por isso se faz necessária a profunda revisão legislativa. O próprio consumidor do segmento musical se encarregará de fazer as mudanças, sem que seja necessário o uso de fórceps para tal.

Note-se, entretanto, que o entendimento não é pela imutabilidade e rigidez absolutas da legislação. Sempre existirão aspectos a serem aprimorados, vide o já mencionado caso da possível criminalização dos usuários de redes P2P e também a necessidade de se incluir como exceção aos direitos autorais a cópia privada, que já constava da lei autoral anterior, mas foi suprimida na atual.

529 Sobre o qual adiante será tratado. 
Por fim, ressalte-se que a proposta de profunda mudança legislativa confronta com a Constituição Federal, que garante, no capítulo das garantias individuais, o conteúdo patrimonial do direito de autor ${ }^{530}$. Ao esvaziá-lo, sob a justificativa de privilegiar o direito de acesso da população às obras autorais, certamente se estará a infringir tal dispositivo constitucional.

b) Outra proposta de solução apresentada é o licenciamento compulsório de obras musicais, com critérios explícitos em lei e mediante a instituição de valores a serem definidos por entidade governamental designada a gerir o funcionamento.

Trata-se de mecanismo já previsto na legislação estadunidense, e seus defensores pugnam pela ampliação das hipóteses de aplicação, atualmente existentes no caso de regravação e distribuição de obras musicais após sua primeira publicação $0^{531} \mathrm{e}$, desde o advento do DMCA, também para qualquer execução efetuada em ambiente digital sem que haja a interatividade com o usuário - inclusive as rádios on-line que preencham tal requisito -, excetuando-se aquelas que retransmitam a programação de uma rádio "tradicional"532.

De acordo com essa proposta, o interessado - por exemplo um digital shop ou um serviço de $\mathrm{P} 2 \mathrm{P}$ - providencia o pagamento segundo as regras definidas pela lei, em valores instituídos pela entidade governamental investida na função e assim tem autorizadas a utilização ou a distribuição das obras musicais digitalizadas.

530 Constituição Federal, "Art. 5. ${ }^{\circ}$ Todos são iguais perante a lei, sem distinção de qualquer natureza, garantindo-se aos brasileiros e aos estrangeiros residentes no País a inviolabilidade do direito à vida, à liberdade, à igualdade, à segurança e à propriedade, nos termos seguintes:

XXVII - aos autores pertence o direito exclusivo de utilização, publicação ou reprodução de suas obras, transmissível aos herdeiros pelo tempo que a lei fixar."

531 "The 'compulsory mechanical license' limits the copyright owner's exclusive right to make phonorecords of most musical works. Once the owner allows someone to make and sell phonorecords of a musical work, anyone else can make his or her own phonorecords of that work. This requires compliance with certain procedural requirements and paying a fee established by the Copyright Office. This license essentially allows the making of so-called 'cover' recordings, where a performer records a song that another performer previously recorded. As long as the compulsory license requirements are complied with, one can go into a recording studio and record, for example, a performance of the song 'Yesterday' as it was written by John Lennon and Paul McCartney and sell compact discs of the recording without the permission of the copyright owner of that musical work." (REESE, R. Anthony. Copyright and Internet Music Transmissions: Existing Law, Major Controversies, Possible Solutions. University of Miami Law Review, v.55, n.2, p.242, Jan. 2001).

532 O licenciamento compulsório já existe, nos Estados Unidos, para as obras musicais cuja execução seja disponibilizada por meio da internet. Esse tema foi explorado no tópico que trata das rádios on-line, no presente estudo. É a entidade SoundExchange, vinculada ao Departamento de Copyright do Congresso Estadunidense, que exerce tal papel. 
O caráter compulsório se dá pela desnecessidade em se obter a autorização dos titulares de direitos autorais, uma vez que preenchidos os requisitos formais estipulados na norma. Para Stan Liebowitz:

É importante notar que o aspecto compulsivo da "licença compulsória" se refere
a uma ação que compele o comportamento do titular do direito autoral, não o
usuário da obra. Um esquema de licenciamento compulsório é aquele no qual o
governo determina que titulares de direitos autorais tornem suas obras
disponíveis ao público, usualmente a um preço fixo. 533

Em síntese, pela proposta, os titulares de direitos autorais lançariam os dados de obras sob sua titularidade num banco de dados governamental, que também seria acessado pelos sistemas dos utilizadores "comerciais" e passaria a haver o confronto do que foi efetivamente distribuído ou executado e automaticamente os valores equivalentes ao definido para tal licenciamento seriam pagos à entidade responsável que, por sua vez, faria o repasse aos titulares, depois de descontadas taxas para o serviço.

$\mathrm{Na}$ teoria, o licenciamento compulsório até pode funcionar, já que teria o condão de conformar a situação posta, consistente na ilicitude da conduta de usuários que utilizam indevidamente obras musicais pela internet, com o interesse dos titulares de direitos autorais. Assim, sendo do entendimento do governo de que os valores praticados pelos titulares são elevados e responsáveis a conduzir os consumidores à ilicitude, determina-se a compulsoriedade do licenciamento mediante preço definido, de modo que os usuários possam agir em respeito aos direitos autorais, já que o valor seria repassado aos respectivos titulares. Pela proposta, todas as obras musicais seriam simultaneamente submetidas a tal licenciamento.

Na prática, entretanto, são diversos os problemas: i) a fixação do valor seria o primeiro. Quais seriam os critérios adotados? Quem deveria pagar: o usuário? O provedor de acesso à internet? Como isso seria feito? Necessariamente a definição do valor seria arbitrária, imposta, igualando desiguais; ii) no caso específico do Brasil, não existe, em matéria de direitos autorais, no ordenamento jurídico, algo semelhante ao que possibilita a licença compulsória nos Estados Unidos. Pelo contrário, a Constituição Federal elenca o

533 Tradução livre de "It is important to note the compulsion aspect of the 'compulsory license' refers to an action compelling the behavior of the copyright owner, not the user of the work. A compulsory licensing scheme is one where the government requires that copyright owners make their works available to users, usually at a fixed price". (LIEBOWITZ, Stan J. Alternative Copyright Systems: The Problems with a Compulsory License. School Of Management. University of Texas at Dallas, 2003. p.3. Disponível em: $<$ http://www.utdallas.edu/ liebowit/intprop/complpff.pdf $>$. Acesso em: 8 dez. 2007). 
direito patrimonial de autor entre as garantias individuais, o que veda alteração legal que contemple tal forma de licenciamento. Poder-se-ia aduzir como fundamento a função social da propriedade, no caso a intelectual, no que igualmente não seria acertado, uma vez que o que justificaria tal entendimento - o acesso aos bens culturais - resta prejudicado pelo fato de que na própria internet se localiza número enorme de obras musicais cujos autores e demais titulares permitem a utilização gratuita, de modo que tal argumento é esvaziado, já que existem opções às obras musicais pelas quais se cobra; iii) ainda, no caso específico do Brasil, trata-se de algo arriscado delegar ao poder público tal função, pois sabe-se que o funcionamento da maioria dos entes estatais deixa a desejar no quesito eficiência.

É a opinião de Stan Liebowitz:

\begin{abstract}
Embora o sistema atual seja obviamente imperfeito, como qualquer sistema deve ser, é improvável que o licenciamento compulsório atinja até mesmo os objetivos mais modestos de um impacto positivo, isso para não dizer nada acerca das alegações de virtual perfeição que tem sido feitas. Apenas pelo fato de um sistema poder existir e sobreviver, não quer dizer que ele seja eficiente sob uma perspectiva econômica. .534
\end{abstract}

c) Outra proposta decorre da experiência estadunidense da regulamentação - e autorização - da cópia privada pelos usuários de música, a partir da lei federal Audio Home Recording Act de 1992.

Como medida de compensação aos titulares de direitos autorais, que seriam prejudicados em detrimento de lucros dos fabricantes das mídias e dos aparelhos, ficou estabelecido o pagamento de uma porcentagem do valor das mídias virgens destinados à gravação de música (os chamados CD-áudio) e também de aparelhos gravadores, desde que não tenham sido fabricados para serem utilizados com microcomputadores.

Tal formulação foi aprimorada por outros países ${ }^{535}$, onde atualmente é utilizada e garante, ao mesmo tempo, o direito de cópia privada dos usuários e resguarda os interesses dos titulares de direitos autorais. Essa regra é denominada private copying levy, que em

534 Tradução livre de "Although the current system is obviously imperfect, as any system must be, it is unlikely that a compulsory license would meet even the modest goals of a net positive impact, to say nothing of the claims of virtual perfection that have been attributed to it. Just because a system could exist and survive, that does not mean that it is efficient from an economic perspective." (LIEBOWITZ, Alternative Copyright Systems..., p.3).

535 Mais de 40 países adotam sistema semelhante, de acordo com Michelle Delio (DELIO, Michelle. Canadians Burned By Blank-CD Levy, 8 jan. 2003, Disponível em: <http:/www.wired.com/entertainment/music/ news/2003/01/57114>. Acesso em: 9 dez. 2007). 
português faria sentido como "cópia privada tarifada" ou ainda, grosso modo, "cópia privada remunerada".

No Canadá são taxadas a importação e a fabricação de todos os tipos de mídia regravável (CD-R inclusive, no valor de 21 centavos de dólar canadense por unidade) e de digital audio players, inclusive os portáteis iPod e congêneres ${ }^{536}$. O procedimento é gerenciado pela Canadian Private Copying Collective (CPCC) ${ }^{537}$, que trata de repassar os valores aos titulares, mediante critérios definidos pelo Copyright Board do Canadá538.

Na Suécia a utilização do private copying levy é ainda mais ampla que nos Estados Unidos e Canadá, válida para diversos tipos de mídia e aparelhos ${ }^{539}$, independentemente do uso que deles se faça. Também é cobrada dos importadores e fabricantes. A diferença principal é que a lei autoral sueca prevê a redução da tarifa no caso de os titulares terem sido de outra maneira compensados pela cópia privada ou se a remuneração é excessiva em razão da natureza do produto ou das condições gerais do mercado. A ampla utilização de DRMs pelos titulares, por exemplo, pode ensejar a redução das tarifas, já que seria subtraído ao consumidor o seu direito de cópia privada ${ }^{540}$.

536 Informa Michel Geist sobre o temor da Associação Canadense da Indústria Fonográfica de que o private copying levy possa "legalizar" a troca de arquivos pelas redes P2P, uma vez que o importador ou fabricante de aparelho leitor portátil já pagou quantia hábil a autorizar a cópia privada efetuada pelo usuário em tal aparelho. $\mathrm{O}$ argumento da indústria fonográfica é que não existe como comprovar a legalidade da fonte da cópia (GEIST, Michel. Fearing Legalized P2P Downloading, CRIA Declares War on Private Copying Levy, 15 set. 2007. Disponível em: <http://www.michaelgeist.ca/content/ view/2238/125/>. Acesso em: 9 dez. 2007).

537 Para maiores informações acerca do funcionamento do sistema canadense, vide <http://www.cpcc.ca/ english/pdf/CPCC-General-Information2.pdf>.

538 O Capítulo VIII, arts. 79 a 88 da Lei autoral canadense (Copyright Act) é destinado ao instituto da cópia privada.

539 DVD-R/RWs, CD-R/RWs (discos de dados), reprodutores de música com armazenamento interno (MP3 Players, iPods), aparelhos reprodutores de DVD e set-top boxes, fitas VHS e fitas-cassete com capacidade de mais de 15 minutos de gravação e fitas cass, more than 15 minutes e Minidiscs.

540 "Under section $26 \S l$, a reduction may be granted if authors are in some other way compensated for any private copying, or if the remuneration is excessive with regard to the nature of the product or conditions generally in the market. The prepatory text to the law states that the rates of remuneration may be reduced if, for example, products that in themselves are particularly suitable for private copying are also widely used for other purposes. A reduction is also possible if consumers - for example at the point of purchasing a disc - also pay certain remuneration to the rightholders via DRM (digital rights management) systems. The levy may also be affected by the presence of TPM such as copy protection." (COPYSWEDE. Private Copying Levy in Sweden 2007. Collection and Distribution: A report from COPYSWEDE. Stockholm, 2007. p.4. Disponível em: <http://www.copyswede.se/files/GVePPPPv.pdf>. Acesso em: 9 dez. 2007). 
$\mathrm{Na}$ Europa, quando da edição da diretiva sobre direitos autorais, foram concedidas aos países-membro as opções de proibir a cópia de obra para uso privado ou autorizá-la e conceder "justa compensação" aos titulares de direitos autorais. Somente cinco dos países optaram por proibir a cópia privada, enquanto os outros preferiram autorizá-la e instituir a tarifa sobre a venda de mídias e aparelhos utilizados para a reprodução.

Objetivando ajustar, com precisão, o private copying levy às tecnologias digitais, a Comissão Européia consultou os países-membro em 2004 e, em 2006, distribuiu às entidades envolvidas, academia e interessados o questionário denominado "Copyright levies in a converging world", cujas respostas compõem as discussões que atualmente estão a ocorrer naquela Comissão.

Autorizar e tarifar a cópia privada de fonte legitimamente adquirida já é, portanto, estratégia adotada em grande número de países, mas não representa solução completa, já que adstrita a apenas um escopo do problema dos direitos autorais na música. Seus defensores sugerem sua ampliação de modo que passe também a abranger o compartilhamento de arquivos via redes $\mathrm{P} 2 \mathrm{P}$. O estudo que está sendo conduzido pela Comissão Européia certamente será de extrema importância para a verificação da possibilidade de alargamento ou, caso se perceba a impossibilidade, da melhor solução para a "cópia privada remunerada".

ii) Constituem propostas aplicáveis sob a égide das legislações atuais: a) o licenciamento individual voluntário; b) o licenciamento coletivo voluntário e c) o Modelo Alternativo de Compensação de Fisher.

a) A proposta de licenciamento individual voluntário revela-se simples e condizente com a legislação autoral em vigor. Consiste no ato de o titular de direitos autorais licenciar a sua obra musical mediante condições que determinar, pela adoção de contrato de licença, portanto utilizando as prerrogativas que lhe são conferidas pelos artigos 28 e 29 da LDA, que versam sobre os direitos patrimoniais.

Tal forma de licenciamento, outrossim, não configura nenhuma novidade, mas sim o fato de que, com o advento da internet, o contato pessoal ou com a editora, que se fazia necessário, possibilitou a criação de mecanismo tecnológico que propicia a ciência do usuário, privado ou comercial, a respeito da forma de licenciamento pretendida pelo autor. 
O maior exemplo é o sistema de licenciamento por meio do Creative Commons que, nas palavras de Ronaldo Lemos ${ }^{541}$ :

\begin{abstract}
Cria instrumentos jurídicos para que um autor, um criador ou uma entidade diga de modo claro e preciso, para as pessoas em geral, que uma determinada obra intelectual sua é livre para distribuição, cópia e utilização. Essas licenças criam uma alternativa ao direito da propriedade intelectual tradicional, fundada de baixo para cima, isto é, em vez de criadas por lei, elas se fundamentam no exercício das prerrogativas que cada indivíduo tem, como autor, de permitir o acesso às suas obras e a seus trabalhos, autorizando que outros possam utilizá-los e criar sobre eles.
\end{abstract}

O Creative Commons é uma iniciativa interessante por oferecer dispositivos contratuais flexíveis e adaptáveis aos interesses de cada autor ou titular, em respeito ao direito positivo ${ }^{542}$ e, conseqüentemente, ao princípio da autonomia privada.

Explica Ronaldo Lemos ${ }^{543}$ que as licenças são escritas em três níveis: para leigos, "explicando no que consiste a licença e quais os direitos que o autor está concedendo"; para advogados, em que a redação da licença se utiliza de termos jurídicos, tornando-a válida perante um determinado ordenamento jurídico" e para técnicos,

em que a licença é transcrita em linguagem de computador, permitindo que as obras sob ela autorizadas no formato digital sejam digitalmente 'marcadas' com os termos da licença, e permitindo que um computador identifique os termos de utilização para os quais uma determinada obra foi autorizada.

Interessante notar que, mais uma vez, a técnica apresenta soluções para os desafios que ela mesma cria. Quando o Creative Commons utiliza-se de marcas digitais para auxiliar na identificação dos termos de utilização, o faz lançando mão de um tipo de DRM, mesmo mecanismo utilizado pela indústria fonográfica, o que corrobora o dito no tópico sobre esse tema, neste estudo, de que, se bem utilizada, a tecnologia do DRM pode ser uma possível solução para o problema dos direitos autorais na música.

541 LEMOS, Direito, tecnologia..., p.83.

542 Nesse sentido, para Ronaldo Lemos: "Por outro lado, esta mudança de paradigma quanto ao direito autoral não renega o direito autoral tradicional. Ao contrário: fundamenta-se nele e nas prerrogativas legais dos autores de autorizarem a utilização de suas obras como bem entenderem. Trata-se de um deslocamento do eixo de 'todos os direitos reservados' para 'alguns direitos reservados' ('all rights reserved' para 'some rights reserved')." (LEMOS, Direito, tecnologia..., p.83).

543 LEMOS, Direito, tecnologia..., p.84. 
O Creative Commons recebe o suporte de grandes e respeitadas universidades dos Estados Unidos (Stanford e Harvard, dentre outras) e, no Brasil, conta com o suporte da Faculdade de Direito da Fundação Getúlio Vargas, do Rio de Janeiro, além do amplo apoio institucional do Ministério da Cultura.

Há que se levar em conta, entretanto, o contexto de criação do Creative Commons, que se deu nos Estados Unidos, país que adota o sistema de proteção do Copyright, de essência comercial, diferente portanto do sistema adotado no Brasil, de natureza moral - e que direitos morais lá praticamente inexistem, conforme já foi visto. Um exemplo é que naquele sistema os direitos autorais podem ser concedidos originariamente a uma pessoa jurídica, enquanto no nosso sistema o direito de autor é conferido tão-somente ao criador pessoa física ${ }^{544}$. Na prática, no Brasil, a eventual transferência de direito do autor há de ser necessariamente expressa e presume-se onerosa ${ }^{545}$, enquanto nos Estados Unidos não necessariamente a pessoa física será a titular originária, o que representa um problema que aqui não temos em relação à autoria.

Diante disso, natural que os dilemas relativos aos direitos autorais, naquele país, sejam essencialmente diferentes daqueles do Brasil, de modo que não se pode simplesmente importar possíveis soluções para o que aqui não constitui grande problema. Daí porque é importante o trabalho efetuado pelos voluntários que fazem a tradução e a adequação das licenças para serem conformadas com o ordenamento jurídico pátrio. E que o façam tendo em vista as diferenças conceituais.

É fato, outrossim, que tanto nos Estados Unidos quanto no Brasil - e isso já foi devidamente analisado nos Capítulos anteriores - nas últimas décadas existiu uma realidade em que os autores e intérpretes sempre estiveram numa situação muito desfavorável em relação à indústria fonográfica. Conforme já foi visto, os modelos contratuais do setor eram "importados" dos Estados Unidos e junto vinham os respectivos problemas. Oxalá agora, ao invés dos problemas, venham as soluções.

\footnotetext{
544 LDA, "Art. 11. Autor é a pessoa física criadora de obra literária, artística ou científica."

545 LDA, "Art. 50. A cessão total ou parcial dos direitos de autor, que se fará sempre por escrito, presume-se onerosa."
} 
b) A Electronic Frontier Foundation, poderosa organização não-governamental que versa sobre novas tecnologias do ponto de vista do consumidor, defende a utilização de um sistema de "licenciamento coletivo voluntário"546, no qual a indústria fonográfica cria uma associação que fará a cobrança de valor mensal "razoável", e enquanto o usuário pagar a "mensalidade" estará em conformidade com a lei, podendo compartilhar música ilimitadamente por meio das redes P2P. O dinheiro coletado, por essa proposta, será dividido entre as gravadoras conforme a popularidade das músicas das quais são titulares.

Essa proposta de solução é muito semelhante ao instituto do licenciamento compulsório, embora receba o nome de "licenciamento coletivo voluntário" e apresenta como fator diferencial apenas o fato de ser gerido diretamente por associação de titulares e, de ser, pretensamente, "voluntário". Isso se diz em vista do que a própria EFF afirma em seu estudo, que espera a "sensibilidade" da indústria fonográfica em aceitar a sua proposta, caso contrário o Governo deve alterar a lei e instituir o licenciamento compulsório e designar órgão público para a gestão ${ }^{547}$. Do mesmo modo, afirmam que os artistas que não aderirem simplesmente não receberão os valores correspondentes à utilização de suas obras nas redes $\mathrm{P} 2 \mathrm{P}$.

Diante disso, resta evidente que a proposta em questão é "voluntária" só na denominação e só não consiste em proposta de licenciamento compulsório porque visa tãosomente manter o Governo estadunidense fora do circuito, com o que certamente a situação dos usuários infratores (aqueles que não pagassem tais taxas mensais) fica mais

546 "EFF has spent the past year evaluating alternatives that get artists paid while making file sharing legal. One solution has emerged as the favorite: voluntary collective licensing. The concept is simple: the music industry forms a collecting society, which then offers file-sharing music fans the opportunity to "get legit" in exchange for a reasonable regular payment, say \$5 per month. So long as they pay, the fans are free to keep doing what they are going to do anyway-share the music they love using whatever software they like on whatever computer platform they prefer-without fear of lawsuits. The money collected gets divided among rights-holders based on the popularity of their music. In exchange, filesharing music fans will be free to download whatever they like, using whatever software works best for them. The more people share, the more money goes to rights-holders. The more competition in applications, the more rapid the innovation and improvement. The more freedom to fans to publish what they care about, the deeper the catalog." (EFF - ELECTRONIC FRONTIER FOUNDATION. A Better Way Forward: Voluntary Collective Licensing of Music File Sharing. "Let the Music Play" White Paper, Fev. 2004. p.1. Disponível em: <www.eff.org/files/collective_lic_wp.pdf>. Acesso em: 1. ${ }^{\circ}$ dez. 2007).

547 "If, instead, they continue their war against the Internet and continue inflicting collateral damage on privacy, innovation and music fans, then it may be time for Congress to take steps to force their hand. Congress can enact a "compulsory license" and create a collecting society to move us toward a sensible solution." (EFF, A Better Way Forward..., p.4-5). 
branda, já que, naquele país, uma coisa é litigar contra a indústria fonográfica ou associação privada, outra com o Governo ou órgão estatal.

c) A proposta de William Fisher ${ }^{548}$, Professor de Propriedade Intelectual da Universidade de Harvard e Diretor do Berkman Center for Internet and Society, centro de estudos especializado em novas tecnologias, daquela mesma instituição, que, segundo palavras de Ronaldo Lemos

Em síntese, a proposta alternativa é a de criação de um modelo de incentivo à
produção intelectual, inicialmente voltado para música e filmes, gerido pelo
Estado, que se encarregaria de coletar os fundos necessários na sociedade e
repassá-los aos criadores. Com isso, seriam suspensas várias das restrições
monopolísticas dos direitos autorais, permitindo que a informação circulasse
livremente e, ainda assim, fazendo com que os autores fossem recompensados de
maneira justa pelo trabalho. 549

Tal proposta leva em conta cálculo de quanto seria razoável para a remuneração dos titulares de direitos autorais e demais sujeitos que teriam prejuízos com a livre distribuição de música pela internet ${ }^{550}$ (para o qual chegou ao número de U\$ 2,5 bilhões de dólares) e propõe que o valor seja arrecadado mediante o imposto de renda, o que daria um acréscimo de U\$27,00 (vinte e sete dólares estadunidenses) por família, em base anual, que ainda poderia ser progressivo em razão da quantia já recolhida aos cofres públicos ${ }^{551}$.

548 Constante do sexto capítulo da sua obra Promises to Keep: Technology, Law, and the Future of Entertainment. Palo Alto: Stanford University Press, 2004.

549 LEMOS, Direito, tecnologia..., p.174. O mesmo autor, na página seguinte, reflete que não será caso de suspensão das "restrições monopolísticas" mas sim de "eliminação" delas: "Em síntese, esse modelo propõe a eliminação de todas as proteções monopolísticas conferidas ao autor pelo direito autoral (sobretudo exclusividade de reprodução e distribuição) e, em contrapartida, estabelece um mecanismo público de remuneração para os autores, com fundos obtidos por meio da cobrança de impostos." (p.175).

550 Também obras audiovisuais, na proposta de Fisher, mas aqui o foco será dirigido às obras musicais e fonogramas.

551 "The two and a half billion dollars a year necessary to run this system might be raised in one of two ways. First, we might increase slightly the federal income tax. Currently, approximately 87 million households pay federal income taxes in the United States. If the increased tax burden were spread evenly over that population, each household would pay an additional \$27 per year. If, more plausibly, the burden were distributed in accordance with the rates those taxpayers are already paying, then taxpayers with higher incomes would pay somewhat more than that amount, while taxpayers with lower incomes would pay less than that amount. This approach would have two major advantages. First, it would be efficient. The relevant tax increases could be implemented without incurring any significant additional administrative costs. Nor would the relevant tax base have to be reevaluated in future years." (FISHER, Promises to Keep..., cap. 6, p.16). 
Como segunda opção, a exemplo do sistema utilizado no private copying levy, é pela ampliação do conceito, não apenas para abranger a cópia privada como todo o conteúdo musical (e audiovisual) da internet, para que sejam taxados os aparatos eletrônicos e as mídias, assim como o acesso à internet. A distribuição seria feita pelo órgão público responsável mediante critérios a serem definidos, sendo que algumas opções foram analisadas no capítulo do livro que lançou tal proposta.

Trata-se, entretanto, de um sistema que dificilmente funcionaria no Brasil, por vários motivos, mas três principais: primeiro, a questão é tratada tão-somente pelo prisma do copyright, ignorando o fato de os sistemas não estarem integralmente harmonizados, mormente em relação aos direitos morais. Segundo, leva em conta uma situação distinta da encontrada no Brasil, já que nos Estados Unidos os serviços estatais são prestados sob as premissas da honestidade e da adoção de padrões de eficiência. O serviço público constitui, no geral, carreira de Estado, que não se vincula ao humor dos ocupantes do governo. Raríssimos são os "cargos em confiança". Terceiro, em relação à cobrança de impostos, o Brasil já é campeão e certamente não seria aceito nem pela população nem pelos congressistas tal tributação, ainda mais no imposto de renda ${ }^{552}$. São fatores que, de forma isolada ou cumulada, inviabilizam essa proposta em nosso país.

Essas propostas, ao lado de outras que são apresentadas na tentativa de conformar a questão dos direitos autorais na música, denotam a preocupação em relação do modo com que a informação é tratada. Nesse sentido, Alexandre Dias Pereira:

Num tempo em que se vai acentuando a distância entre os que têm informação e
os que não a têm, em que a informação constitui um bem económico que é
objecto de negócios no mercado da informação, urge que essa revisão se faça em
atenção às 'necessidades da sociedade da informação'. Necessidades essas que,
adiante-se, obstam a que a informação composta por objectos do direito de autor
e direitos conexos (obras literárias e artísticas, e prestações artísticas e
empresariais) seja tratada segundo uma abordagem puramente mercantilista, que
não atenda, designadamente, aos interesses pessoais dos criadores e artistas, à
privacidade dos utilizadores, e ao interesse geral do livre fluxo de informação. ${ }^{553}$

552 Isso sem levar em conta o fato de ser missão difícil - talvez impossível - coordenar tal proposta em vista da legislação e dos princípios do direito tributário.

553 PEREIRA, Informática, direito..., p.24. 
Com efeito, é a conformação dos interesses múltiplos - e por vezes tão discrepantes - que a proposta eficaz deve almejar, mas, ao contrário, percebeu-se que algumas delas são revestidas de caráter ideológico, com o que acabam por privilegiar em demasia um ponto de vista em relação ao outro. Assim, para que os objetivos sejam atingidos, necessário se faz que os sujeitos envolvidos - inclusive a academia - reflitam sobre a situação posta e propostas já elaboradas. 


\section{CONCLUSÕES}

$\mathrm{O}$ assunto enfrentado nesta tese projeta o conflito entre os direitos autorais e o direito de acesso aos bens culturais. A conformação de ambos constitui um relevante desafio trazido pelos novos tempos da chamada "sociedade da informação", na qual a informação é cada vez mais valorizada, sendo que a música digital está inserida nesse contexto.

É interessante notar, outrossim, que tal conflito, no âmbito dos sujeitos envolvidos ao contrário do caráter dúplice que se supõe haver -, é tripartite, composto pelos usuários, que pretendem o acesso ao maior número de obras musicais possíveis (de preferência sem ter que pagar); pelos investidores no mercado fonográfico que pretendem cada vez mais lucrar com a circulação das obras musicais, mas que muitas vezes adotam parâmetros próprios irrazoáveis e, por fim, os compositores, que deveriam ser efetivamente protegidos pela legislação autoral, mas que acabam relegados a um plano inferior, conforme se procurou retratar nas constantes e subseqüentes crises do direito autoral na música.

Ao consumidor de música, desde o início da indústria fonográfica, foi destinado um papel passivo, limitando o seu acesso às obras musicais que fossem escolhidas por esta indústria, ao preço por ela determinado. Com os avanços tecnológicos, porém, esse mesmo consumidor passou a ter voz ativa, não somente por meio da interatividade, mas também pela facilidade de acesso às obras musicais extremamente diversificadas, ofertadas diretamente por músicos que, por razões estéticas e mercadológicas, não teriam, em outras circunstâncias, condições materiais de exposição e oferta de suas obras à comunidade.

Ademais, a tecnologia permite a seleção individual das faixas musicais escolhidas, rompendo a prática usual de se obrigar o consumidor a adquirir um meio físico contendo músicas que nem sempre correspondem ao seu gosto.

Ocorre que, por inação da indústria fonográfica nos primeiros anos da internet, foi criado o hábito de se acessar às músicas sem o pagamento de contraprestação, dando origem a uma situação fática complexa, já que, para toda uma geração de jovens usuários, fazer trocas de músicas pela internet constitui tarefa comum e até moralmente aceitável, muito embora - em decorrência das ações judiciais que as entidades associativas da indústria fonográfica ingressaram contra usuários, que recebem da imprensa grande destaque - tenham conhecimento inequívoco de que tais atos são ilícitos.

É importante notar que o papel da indústria fonográfica foi de fundamental importância para a disseminação da música, mormente nas primeiras décadas de sua 
instalação e desenvolvimento, pois, a seu modo, promoveu pesados investimentos. Essa indústria criou e solucionou uma das importantes crises do direito do autor no música. Essa dívida histórica, entrentanto, já foi quitada, acrescida de juros e correção monetária.

Passou-se, a partir disso, à contraposição de dois importantes pontos de vista ${ }^{554}$ : de um lado, aqueles que pretendem a manutenção do status da legislação autoral e cada vez garantir mais direitos e os lucros deles decorrentes e, por outro, a maior parte dos usuários, representada por proeminentes membros da academia, que advogam pela alteração legislativa profunda, até mesmo mediante a eliminação de direitos exclusivos concedidos aos titulares de direitos autorais. Concluiu-se, entretanto, que há exageros de ambos os lados, que por vezes lançam mão de discurso permeado pelo maniqueismo e por uma insensibilidade a respeito dos diversos atores envolvidos no mercado fonográfico.

Já os compositores, dos quais pouco se têm notícias em tais debates - a maioria deles teve que ceder os respectivos direitos autorais patrimoniais às gravadoras -, são utilizados pelas gravadoras como justificativa para as cobranças de valores, que supostamente a eles seriam destinados. Sabe-se que a realidade, na maioria dos casos, é diferente: a eles somente cabe pequena porção da fatia econômica decorrente da riqueza que eles mesmos criaram ${ }^{555}$. Isso faz com que sejam mal-vistos pelos usuários, aqueles para os quais dedicam a sua arte, que os vêem como componentes "do outro lado", considerando o discurso maniqueista anteriormente exposto. Infelizmente, parece que os destinatários da legislação autoral acabam por atuar como espectadores de um espetáculo no qual pretensamente seriam os protagonistas.

Tal situação é paradoxal, já que o interesse dos compositores e intérpretes contempla os interesses dos investidores culturais e do público, pelo fato de que tanto quer ver sua obra disseminada ao máximo por entre os usuários quanto quer auferir renda delas ${ }^{556}$.

554 Tal cenário conflituoso foi notado por Alexandre Dias Pereira: "Cumpre referir, desde já, que neste processo de adaptação do direito de autor ao paradigma da tecnologia digital a máxima parece ser o 'reforço' dos direitos de propriedade intelectual. Contudo, esse reforço de protecção no novo ambiente digital põe em causa certos valores fundamentais, como sejam o livre fluxo da informação". (PEREIRA, Informática, direito..., p.19).

555 Isso quando fazem jus ao efetivo recebimento, em vista dos adiantamentos que são efetuados e posteriormente cobrados com juros e correção monetária, a depender do sucesso da composição.

556 Nesse sentido, Christophe Geiger: "a doutrina do direito do autor teve a tendência de colocar lado a lado o autor e o público. Estes teriam interesses radicalmente opostos: o autor teria a vontade de submeter toda utilização de suas obras à sua autorização, autorização que ele permitirá mediante o pagamento de uma renda, e o público teria a vontade de utilizar ao máximo as obras do autor gratuitamente, sem uma 
Esse cenário de conflito de interesses, que é o pano de fundo para a mais recente crise do direito do autor na música, dificilmente seria solucionável não fosse justamente o advento da internet, que possibilitou a profunda transformação nos hábitos dos usuários tal como constatado na presente tese. Mais uma vez, a causa da crise pode ser o "princípio ativo" do remédio.

Noutras palavras: muito do que é considerado problema é, na realidade, solução. A disseminação do uso da tecnologia pelos compositores e intérpretes e a utilização, por eles, de serviços específicos na internet - além de mecanismos contratuais alternativos de licenciamento -, propiciaram meios alternativos para que desenvolvessem um novo modelo de negócios, em que a indústria fonográfica deixou de ser protagonista e passou a ser coadjuvante.

contrapartida em dinheiro. Haveria então um tipo de luta enfurecida entre de um lado o autor que deseja cobrar tudo e de outro o público que não deseja pagar nada. Essa apresentação caricatural de uma oposição entre o autor e seu público, de tal forma que podemos às vezes a encontrar em filigrana na literatura que versa sobre direito do autor, poderia surpreender, e em primeiro lugar, as partes concernentes: $\mathrm{O}$ autor, primeiramente, que incansavelmente cultiva o público, busca a sua atenção, sua admiração e seu apoio, e o público em seguida, que venera e idolatra aquele que, para retomar a expressão de um autor, "nos instrui,... nos diverte,... nos proporciona um ambiente de vida mais agradável...". O autor e o público, numa relação íntima de sedução permanente, se oporiam radicalmente na seara do direito? Isso parece improvável. De fato, a relação entre autor e público parece alterada no âmbito do direito do autor por um terceiro ator da atividade cultural, o explorador, que dará as cartas. Este, conforme a situação, irá se meter na pele do autor, seja na pele do público para defender os interesses que lhe são próprios. Como destaca M. Cohen-Jehoram a respeito dos interesses subjacentes ao direito do autor, "é muito mais simpático e eficaz lutar aparentemente pelos direitos de qualquer outro do que por seus próprios interesses". Tradução livre de "La doctrine du droit d'auteur a eu tendance it mettre dos it dos l'auteur et le public. Ceux-ci auraient des intérêts radicalement opposes: l'auteur aurait la volonté de soumettre toute utilisation de ses reuvres it son autorisation, autorisation qu'il monnayera contre payement d'une redevance, et le public aurait la volonté d'utiliser au maximum les reuvres de l'auteur gratuitement, sans bourse delier. Il y aurait donc une sorte de lutte acharnee entre d'un cote l' auteur qui voudrait faire tout payer et de l'autre le public qui voudrait ne rien payer. Cette presentation caricaturale d'une opposition entre l'auteur et son public, telle qu'on peut parfois la trouver en filigrane dans la litterature du droit d'auteur, pourrait surprendre, et en premier lieu les parties concernees: l'auteur d'abord, qui inlassablement courtise le public, recherche son attention, son admiration et son soutien, et le public ensuite, qui venere et idolatre ceux qui, pour reprendre l'expression d'un auteur, 'nous instruisent,... nous divertissent,... nous rendent plus agreable l'ambiance dans laquelle nous vivons...'. L'auteur et le public, dans un rapport intime de seduction permanente, s'opposeraient radicalement sur le terrain du droit? Cela semble improbable. En fait, le rapport entre auteur et public semble fausse sur le terrain du droit d'auteur par un troisieme acteur de l'activite culturelle, l'exploitant, qui va venir brouiller les cartes. Celui-ci, selon la situation, se glissera soit dans la peau de l'auteur, soit dans la peau du public pour defendre des interets qui lui sont propres. Comme le souligne M. CohenJehoram a propos des interets sous-jacents au droit d'auteur, 'il est tellement plus sympathique et efficace de se battre apparemment pour les droits de quelqu'un d'autre plutôt que pour ses propres interets'". (GEIGER, Droit d'auteur..., p.54). 
Nesse novo mercado musical, os compositores e intérpretes podem oferecer suas músicas da maneira que desejarem, licenciando-as gratuita ou onerosamente. Podem, também, contratar com a indústria fonográfica se desejam contar com assessoria especializada. Em igual medida, possibilita-se a cada músico gerir pessoalmente sua carreira. As opções são múltiplas. Também é assim com o usuário, que pode decidir se pretende escutar música gratuita ou paga, já que encontra inúmeras opções de ambas as formas. É o princípio da autonomia privada a ser exercido no âmbito dos direitos autorais na música.

No cenário apresentado, no entanto, permite-se uma maior preservação da verdadeira autonomia dos compositores, intérpretes em detrimento do poder da indústria fonográfica que, tradicionalmente, tolhia a autonomia dos demais.

É certo que, sob a direção da indústria fonográfica, buscou-se recrudescer as normas autorais no decorrer dos anos. Em que pese terem garantido a si, de forma direta, diversos direitos (os direitos conexos), tinham o hábito de, principalmente, fazê-lo de forma dissimulada, sob o pretexto de proteger o autor, de quem na verdade eram cessionárias nos direitos patrimoniais. Noutras palavras, propunham normas das quais seriam as reais beneficiárias sob o discurso simpático da proteção ao compositor.

Outrossim, o fato de a legislação autoral lançar firme proteção ao autor deve ser louvado. Alguns ajustes são necessários, no entanto, para que esse autor possa efetivamente voltar à posição de efetivo destinatário da norma. $\mathrm{O}$ que não se pode admitir é a manutenção da prática, denunciada e repudiada pelo Professor Fabio Maria De Mattia em sua obra "O autor e o editor na obra gráfica", citada no presente trabalho, no sentido de que se mantenha a permissão da cessão definitiva e integral dos direitos patrimoniais do autor. Sabe-se que, nesse mercado, a cessão definitiva e integral dos direitos patrimoniais do autor é o mecanismo utilizado para se retirar a autonomia do artista e, por conseqüência, a autonomia dos consumidores. Eis o tempo para superar essa nova crise.

Defende-se a ampla possibilidade sustentada na tecnologia inovadora exposta ao longo do trabalho a liberdade de o autor licenciar sua obra da maneira que desejar, sem que essa liberdade seja o fio condutor para a sua escravidão.

Outra proposta de alteração legislativa é a garantia do direito à cópia privada, a ser feita mediante a instituição de medida que recompense os titulares de direitos autorais, em semelhança ao que ocorre na Comunidade Européia, Canadá e outros países, conforme visto no presente estudo. 
A terceira medida de grande importância é a alteração legislativa que vise esclarecer sobre a não-incidência do usuário de redes P2P que efetue compartilhamento não-autorizado de arquivos digitais no tipo penal da violação dos direitos autorais.

Entretanto, mais do que propostas, é de se questionar acerca do autor-compositor: em vista de todas as mudanças causadas pelas novas tecnologias, qual o papel que agora lhe cabe? Continuará subjugado aos interesses dos grandes investidores culturais, recebendo ínfima recompensa ou, terá efetivamente a chance de ser devidamente reconhecido e remunerado? Nesta tese defende-se a segunda hipótese.

As perguntas e as respostas encontram-se submetidas, para além das paredes da academia, ao caráter mutável imposto pela rapidez dos avanços tecnológicos, em que os problemas atuais podem não mais o ser em questão de horas, ao sobrevir novidade técnica que os encerre.

Finalmente, o que se espera de todos os envolvidos é a aplicação do bom senso, mediante a compreensão de que as novas tecnologias sempre trarão desafios e que, na maioria das vezes, elas mesmas trazem junto as soluções. As crises, portanto, podem ser apenas o prenúncio de um novo tempo que, se espera, melhor. 


\section{REFERÊNCIAS}

1. ABPD. Publicação anual do mercado fonográfico ABPD 2005. Rio de Janeiro, 2006.

2. ABPD - Associação Brasileira dos Produtores de Discos. Disponível em: $<$ http://www.abpd.org.br/noticias_internas.asp?noticia=147>. Acesso em: 9 ago. 2007.

3. ABPI - Associação Brasileira da Propriedade Intelectual. Resolução: O MP3 e a proteção dos direitos autorais. Revista da ABPI - Associação Brasileira da Propriedade Intelectual, n.49, nov./dez. 2000.

4. ACEL - Associação Nacional de Operadoras Celulares. Acel avalia cobrança de direito autoral sobre toques telefônicos musicais. 5 abr. 2005. Disponível em: $<$ http://www.acel.org.br/003/00301009.asp?ttCD_CHAVE=7383>. Acesso em: 8 out. 2007 .

5. AGÊNCIA FRANCE PRESSE, NY. Reportagem. Folha de São Paulo, 17 maio 2007, Caderno Informática. Disponível em: <http://www1.folha.uol.com.br/ folha/informatica/ ult124u22070.shtml>. Acesso em: 24 ago. 2007.

6. APDIF - Associação Protetora dos Direitos Intelectuais Fonográficos. Disponível em: $<$ http://www.socinpro.org.br/piratinternet.htm>. Acesso em: 9 ago. 2007.

7. AKESTER, Patrícia. O direito de autor e os desafios da tecnologia digital. Cascais: Principia, 2004.

8. ANDERSON, C.A., FUNK, J.B. e GRIFFITHS, M. D. Video Games and Public Health. Journal of Adolescence, v.27, n.1, p.1-122, February 2004.

9. ARE, Mario. L'oggetto del diritto di autore. Milão: Giuffrè, 1963.

10. ASCENSÃO, José de Oliveira. Direito de autor e informática jurídica. In: Estudos sobre direito da internet e sociedade da informação. Coimbra: Almedina, 2001.

11. ASCENSÃO, José de Oliveira. Novas tecnologias e transformação do direito de autor. In: . Estudos sobre direito da internet e sociedade da informação. Coimbra: Almedina, 2001. 
12. ASCENSÃO, José de Oliveira. O direito de autor no ciberespaço. In: Estudos sobre direito da internet e sociedade da informação. Coimbra: Almedina, 2001.

13. ASCENSÃO, José de Oliveira. Os direitos de autor no domínio das telecomunicações. In: . Estudos sobre direito da internet e sociedade da informação. Coimbra: Almedina, 2001.

14. ASCENSÃO, José de Oliveira. Aspectos jurídicos da distribuição em linha de obras literárias, musicais, audiovisuais, bases de dados e produções multimédia. In: Direito da sociedade da informação. Coimbra: Coimbra Editora, 2004. v.5.

15. ASCENSÃO, José de Oliveira. Convergências de tecnologias: perspectivas jurídicas. In: Direito da sociedade da informação. Coimbra: Coimbra Editora, 2004.

16. AUGUSTO, Sérgio. CDs e lojas de CDs: morte anunciada. O Estado de São Paulo, São Paulo, 31 mar. 2007, Caderno 2, p.D5.

17. BALSANO, Anna Maria. An International Legal Instrument for Cyberspace? A Comparative Analysis with the Law of Outer Space. In: International Dimensions of Cyberspace Law. Paris: UNESCO, 2000.

18. BARBOSA, Conceição Aparecida Pereira; SERRANO, Claudia Aparecida. O Blog como ferramenta para construção do conhecimento e aprendizagem colaborativa. Disponível em: <http://www.abed.org.br/congresso2005/por/pdf/011tcc3.pdf $>$. Acesso em: 12 nov. 2007.

19. BARBOSA, Denis Borges. Uma introdução à propriedade intelectual. Rio de Janeiro: Lúmen Júris, 2003.

20. BARBOSA, Denis Borges. A posse e a propriedade na concorrência. Disponível em: $<$ http://www.uj.com.br/publicacoes/doutrinas/default.asp?action=doutrina\& iddoutrina $=2956>$. Acesso em: 17 nov. 2007.

21. BARBOSA, Denis Borges; JESSEN, Nelida Jabik. O uso livre de música encontrada na internet. 2000. Disponível em: $<$ http://denisbarbosa.addr.com/116.DOC $>$. Acesso em: 27 out. 2007. 
22. BENHAMOU, Françoise; FARCHY, Joëlle. Droit d'auteur et copyright. Paris: La Découverte, 2007.

23. BERNARDES DE MELLO, Marcos. Teoria do fato jurídico: plano da existência. 13.ed. São Paulo: Saraiva, 2007.

24. BERTRAND, André. La musique et le droit De Bach à Internet. Paris: Éditions Litec, 2002.

25. BEVILACQUA, Clovis. Direito das coisas. 2.ed. atual. Rio de Janeiro: Freitas Bastos, 1946. v.1.

26. BITTAR, Carlos Alberto. Curso de direito autoral. Rio de Janeiro: Forense, 1988.

27. BLAKENEY, Michael. The international protection of industrial property: From the Paris Convention to the TRIPS agreement. Cairo: OMPI, 2003.

28. BOBBIO, Pedro Vicente. O direito de autor na creação musical. São Paulo: LEX, 1951.

29. BRAGA, Glória. Propriedade intelectual: não há conflito entre novas tecnologias e direito autoral. Revista Consultor Jurídico, 5 jul. 2005. Disponível em: $<$ http://conjur.estadao.com.br/static/text/36033,1>. Acesso em: 8 out. 2007.

30. BRAIN, Marshall. "Como funcionam os modens" em HowStuffWorks. Verbete. Disponível em: <http://informatica.hsw.uol.com.br/modem1.htm>. Acesso em: 13 out. 2007.

31. BUONO, Francis M. e FRIEDMAN, Jonathan A. Maximizing the Enforceability of Click-Wrap Agreements. Journal of Technology Law \& Policy, University of Florida Levin College of Law, v.4, n.3, 1999.

32. CANOTILHO, J. J. Gomes; MACHADO, Jónatas E. M. Machado. 'Reality Shows' e liberdade de programação. Coimbra: Coimbra Editora, 2003.

33. CARBONI, Guilherme. Função social do direito de autor. Curitiba: Juruá, 2006.

34. CARON, Christophe. Abus de droit et droit d'auteur. Paris: LITEC, 1998. 
35. CARPANEZ, Juliana. Podcasts trazem novos desafios à indústria fonográfica. Folha Online, São Paulo, 20 fev. 2006. Disponível em: <http://www1.folha.uo1.com.br/folha/ informatica/ult12419676.shtml>. Acesso em: 14 nov. 2007.

36. CHAVES, Antonio. Proteção internacional do direito autoral de radiodifusão. São Paulo: Max Limonad, 1952.

37. CHAVES, Antonio. Proteção internacional do direito autoral de radiodifusão. São Paulo: Marajó, s/d.

38. CHAVES, Antônio. Direito do autor: princípios fundamentais. Rio de Janeiro: Forense, 1987.

39. CHAVES, Antônio. Criador da obra intelectual. São Paulo: LTr, 1995.

40. CHERNIJ, Carlos. Bill Gates aposta que celular vai substituir iPod. Info Online, São Paulo, 12 maio 2005. Disponível em: <http://info.abril.com.br/aberto/infonews/ 052005/12052005-6.shl>. Acesso em: 8 out. 2007.

41. COMMISSION OF THE EUROPEAN COMMUNITIES. Digital Rights: Background, Systems, Assessment. Comission Staff Working Paper. Bruxelas, 14 fev. 2002.

42. CONTI, Fátima. Muitas dicas. Disponível em: <http://www.cultura.ufpa.br/dicas/ progra/arq-cod.htm>. Acesso em: 5 maio 2007.

43. COPYSWEDE. Private Copying Levy in Sweden 2007. Collection and Distribution: A report from COPYSWEDE. Stockholm, 2007. p.4. Disponível em: $<$ http://www.copyswede.se/files/GVePPPPv.pdf>. Acesso em: 9 dez. 2007.

44. CORDEIRO, Pedro João Fialho da Costa. Direito de autor e radiodifusão: um estudo sobre o direito de radiodifusão desde os primórdios até à tecnologia digital. Coimbra: Almedina, 2004.

45. De ANGELIS, Deborah. La tutela giuridica delle opere musicali digitali. Milão: Giuffrè, 2005.

46. DE MATTIA, Fabio Maria. O autor e o editor na obra gráfica: direitos e deveres. São Paulo: Saraiva, 1975. 
47. DE MATTIA, Fabio Maria. O direito de tradução no direito comparado. In: Estudos de direito de autor. São Paulo: Saraiva, 1975.

48. DE SANCTIS, Vittorio M.; FABIANI, Mario. I contratti di Diritto di Autore. Milão: Giuffrè, 2000.

49. DELIO, Michelle. Canadians Burned By Blank-CD Levy, 8 jan. 2003. Disponível em: $<$ http://www.wired.com/entertainment/music/news/2003/01/57114>. Acesso em: 9 dez. 2007.

50. DIAS, Marcia Tosta. Os donos da voz: indústria fonográfica brasileira e mundialização da cultura. São Paulo: Boitempo, 2000.

51. DICIONÁRIO AURÉLIO. Copyright. Disponível em: $<$ http://www.wipo.int/aboutip/en/copyright.html>. Acesso em: 28 maio 2006.

52. DICIONÁRIO HOUAISS. Internet. Disponível em: <http://houaiss.uol.com.br/ busca.jhtm? verbete $=$ internet $\& \mathrm{x}=0 \& \mathrm{y}=0 \&$ stype $=\mathrm{k}>$. Acesso em: 19 mar. 2007.

53. DICIONÁRIO HOUAISS. Baixar. Disponível em: $<$ http://houaiss.uol.com.br/ busca.jhtm?verbete=baixar\&stype=k>. Acesso em: 7 abr. 2007.

54. DICIONÁRIO OXFORD. Disponível em: <http://www.askoxford.com/ worldofwords/bubblingunder/archive/bubbling_06/>. Acesso em: 7 out. 2007.

55. DILGER, Daniel Eran. How FairPlay Works: Apple's iTunes DRM Dilemma. RouglyDrafted Magazine, 26 fev. 2007. Disponível em: <http://www.roughlydrafted.com/ RD/RDM.Tech.Q1.07/2A351C60-A4E5-4764-A083-FF8610E66A46.html>. Acesso em: 24 ago. 2007.

56. DORIA, Pedro. Perda de capricho. O Estado de São Paulo, São Paulo, 27 nov. 2006, Caderno Link, p.L12.

57. DOWNING, Douglas. Dictionary of Computer and Internet Terms. 6.ed. New York: Barron's, 1998. 
58. EFF - ELECTRONIC FRONTIER FOUNDATION. A Better Way Forward: Voluntary Collective Licensing of Music File Sharing. "Let the Music Play" White Paper, Fev. 2004. p.1. Disponível em: <www.eff.org/files/collective_lic_wp.pdf>. Acesso em: 1. ${ }^{\circ}$ dez. 2007

59. EFF - ELECTRONIC FRONTIER FOUNDATION. Unintended Consequences: Seven Years under the DMCA, versão 4, abril de 2006. Disponível em: $<$ http://www.eff.org/IP/DMCA/unintended_consequences.php>. Acesso em: 19 ago. 2007.

60. ELLMERICH, Luis. História da música. 2.ed. São Paulo: Boa Leitura, 1964.

61. EMERY, Miguel Ángel. Propriedad Intelectual. Buenos Aires: Editorial Astrea, 2003.

62. FISHER, William. Promises to Keep: Technology, Law, and the Future of Entertainment. Palo Alto: Stanford University Press, 2004.

63. FOLHA ONLINE. Conteúdo para celulares deve movimentar US\$ 43 bi em 2010. publicado em 1. ${ }^{\circ}$ de ago. 2005. Disponível em: <http://www1.folha.uol.com.br/ folha/informatica/ult124u18754.shtml>. Acesso em: 7 out. 2007.

64. FRAUNHOFER INSTITUTE FOR DIGITAL MEDIA TECHNOLOGY IDMT. Metadata Retrieval and Processing. Disponível em: $<$ http://www.iis.fraunhofer.de/ fhg/Images/MD_gesamt_en_cont_tcm278-76020.pdf>. Acesso em: 18 ago. 2007.

65. Gartner|G2 \& BERKMAN CENTER. iTunes: How Copyright, Contract, and Technology Shape the Business of Digital Media - A Case Study. Cambridge: Harvard Law School, 15 jun. 2004.

66. GartnerG2; THE BERKMAN CENTER FOR INTERNET \& SOCIETY AT HARVARD LAW SCHOOL. Copyright and Digital Media in a Post-Napster World. Version 2. Cambridge: Harvard Law School, jan. 2005.

67. GASSER, Urs; BEGUE, Gabriela Ruiz. iTunes: Some Observations After 500 Million Downloaded Songs. Cambridge: Harvard Law School, ago. 2005.

68. GAUTIER, Pierre-Yves. Propriété littéraire et artistique. 2e éd. mise à jour. Paris: Presses Universitaires de France, 1996. 
69. GEIGER, Christophe. Droit d'auteur et droit du public à l'information. Paris: LITEC, 2004.

70. GEIST, Michel. Fearing Legalized P2P Downloading, CRIA Declares War on Private Copying Levy, 15 set. 2007. Disponível em: <http://www.michaelgeist.ca/ content/view/2238/125/>. Acesso em: 9 dez. 2007.

71. GHIDINI, Gustavo; MONTAGNANI, Maria Lillà. Esercizio del diritto d'autore e dei diritti conessi in ambiente digitale e dispositivi tecnologici di controlo dell'accesso ai contenuti. In: SPADA, Paolo (Org.). Quaderni di AIDA n. 16: Gestione colletiva dell'oferta e della domanda di prodotti culturali. Milão: Giuffrè, 2006.

72. GIL, Gilberto. Por uma reforma da lei do direito autoral. O Globo, Rio de Janeiro, 11 out. 2007, Segundo Caderno, p.4.

73. GORDON, Steve. The future of the music business: how to succeed with the new digital techonologies. São Francisco: Backbeat Books, 2005.

74. GUERRA FILHO, Willis Santiago. Teoria processual da constituição. São Paulo: Celso Bastos Editor: Instituto Brasileiro de Direito Constitucional, 2000.

75. GUNDERSEN, Edna. Mastertones ring up profits. USA TODAY, McLean, 29 nov. 2006. Disponível em: <http://www.usatoday.com/life/music/news/2006-11-28mastertones-main_x.htm>. Acesso em: 7 out. 2007.

76. HAMMES, Bruno Jorge. O direito de propriedade intelectual: subsídios para o ensino. 3.ed. São Leopoldo: Ed. Unisinos, 2002.

77. HASLAM, Karen. Comissária da União Européia critica vinculação de iPod e iTunes. Matéria jornalística publicada no IDGNOW, 12 mar. 2007. Disponível em: $<$ http://idgnow.uol.com.br/computacao_pessoal/2007/03/12/idgnoticia.2007-0312.0627774807/>. Acesso em: 24 ago. 2007.

78. HELLMUT, Oliver et al. Advanced Audio Identification Using MPEG-7 Content Description. Erlangen: Fraunhofer Institute for Integrated Circuits IIS-A, 2001. 
79. HELLMUT, Oliver et al. Using MPEG-7 Audio Fingerprinting in Real-World Applications. Erlangen: Fraunhofer Institute for Integrated Circuits IIS-A, 2003.

80. HIMANEN, Pekka. A ética dos hackers e o espírito da era da informação: a importância dos exploradores da era digital. Trad. Fernanda Wolff. Rio de Janeiro: Campus, 2001.

81. IAZZETTA, Fernando. O que é a música (hoje). Trabalho apresentado no I FÓRUM CATARINENSE DE MUSICOTERAPIA, Florianópolis, 31 ago. e 01 set. de 2001. Disponível em: <http://www.eca.usp.br/prof/iazzetta/papers/forum2001.pdf>. Acesso em: 10 dez. 2007.

82. IFPI - International Federation of the Phonographic Industry. IFPI 2007: Record Industry in Numbers. Londres: IFPI, 2007.

83. IFPI - International Federation of the Phonographic Industry. IFPI:07 Digital Music Report. Londres: IFPI, 2007.

84. IMFELD, Cassandra Jacqueline. Repeated resistance to new technologies: a case study of the recording industry's tatics to protect copyrighted works in cyberspace between 1993 and 2003. 2004. Tese (Doutorado em Filosofia) - Departamento de Jornalismo e Comunicação de Massa - University of North Carolina, Chapel Hill, 2004.

85. IMMINK, Kess A. Schouhamer. The compact disc history. J. Audio Engineering Society, v.46, n.5, p.458-465, maio 1998. Disponível em: <http://www.exp-math.uniessen.de/ immink/pdf/cdstory.pdf>. Acesso em: 29 nov. 2006.

86. JOBS, Steve. Thoughts on music. Publicado em 6 fev. 2007. Disponível em: $<$ http://www.apple.com/hotnews/thoughtsonmusic/>. Acesso em: 9 ago. 2007.

87. KAMINSKI, Omar. A internet e o ciberespaço. Disponível em: $<$ http://buscalegis.ccj.ufsc.br/arquivos/a14-internetC.htm>. Acesso em: 6 maio 2007.

88. KENNEDY, John. The evolving business of music. In: Recording Industry in Numbers. London: IFPI, 2007. 
89. KIRSH, Steven J. The effects of violent video games on adolescents: The overlooked influence of development. Aggression and Violent Behavior, v.8, n.4, p.377-389, July-August 2003.

90. KRASILOVSKY, M. William; SHEMEL, Sidney. This business of music: the definitive guide to the music industry. 9.ed. Nova Iorque: Watson-Guptill Publications, 2003.

91. KRETSCHMER, Martin; KAWOHL, Friedemann. The History and Philosophy of Copyright. In: FRITH, Simon; MARSHALL, Lee (Orgs.). Music and Copyright. 2.ed. Edimburgo: Edinburgh University Press, 2004.

92. KUSEK, David; LEONHARD, Gerd. The future of music: manifesto for the digital music revolution. Boston: Berklee Press, 2005.

93. LEGRAND, Gerard. Dicionário de filosofia. Lisboa: Edições 70, 1986.

94. LEITE, Eduardo Lycurgo. Direitos autorais nas mídias digitais. Revista da ABPI Associação Brasileira da Propriedade Intelectual, n.49, p.3-21, nov./dez. 2000.

95. LEMOS, Ronaldo. Direito, tecnologia e cultura. Rio de Janeiro: FGV, 2005.

96. LEONARDO, Rodrigo Xavier. Redes contratuais no mercado habitacional. São Paulo: Revista dos Tribunais, 2003.

97. LEONARDO, Rodrigo Xavier. A função social da propriedade: em busca de uma contextualização entre a Constituição Federal e o Novo Código Civil. Revista da Faculdade de Direito de São Bernardo do Campo, ano 8, n.10, p.271-290, 2004.

98. LESSIG, Lawrence. Cultura livre: como a grande mídia usa a tecnologia e a lei para bloquear a cultura e controlar a criatividade. São Paulo: Trama, 2005.

99. LEVINE, Robert. EUA aumentam taxa de música online. Originalmente publicado no The New York Times. Disponível em: <http://www.link.estadao.com.br/ index.cfm?id_conteudo=10541>. Acesso em: 27 de out. 2007. 
100. LIEBOWITZ, Stan J. Alternative Copyright Systems: The Problems with a Compulsory License. School Of Management. University of Texas at Dallas, 2003. Disponível em: $<$ http://www.utdallas.edu/ liebowit/intprop/complpff.pdf $>$. Acesso em: 8 dez. 2007

101. LIEBOWITZ, Stan J. The Elusive Symbiosis: The Impact of Radio on the Record Industry. School Of Management. Dallas: University of Texas. Mar. 2004.

102. LIPSZYC, Delia. Derecho de autor y derechos conexos. Paris: UNESCO, 2001.

103. LOEBER, Dietrich A. "Socialist" Features of Soviet Copyright Law. Columbia Journal of Transnational Law, n.23, p.297-313, 1984-1985.

104. LOSANO, Mario G. Lições de informática jurídica. São Paulo: Resenha Tributária, 1974.

105. LOSSO, Ezequias. Atividade empresarial de telefonia de radiofreqüência e inclusão social. 2007. Dissertação (Mestrado em Direito) - Faculdades Integradas Curitiba, Curitiba, 2007.

106. MANSO, Eduardo Vieira. Direito autoral: exceções impostas aos direitos autorais: derrogações e limitações. São Paulo: Bushatski, 1980.

107. MARMELSTEIN, George. Um tapinha dói ou não dói? A censura na música após a Constituição de 88 - limites à liberdade de expressão musical. In: Get Up, Stand Up, Stand Up For Your Rights. 12 de Setembro de 2007. Blog acessível por: $<$ http://georgemlima.blogspot.com/2007/09/um-tapinha-di-ou-no-di-censura-namsica.html>. Acesso em: 3 out. 2007.

108. MARTINS, Rodrigo. Vídeo Game 'In Concert'. O Estado de São Paulo, São Paulo, 27 ago. 2007, Caderno Link. Disponível em: <http://www.link.estadao.com.br/ index.cfm?id_conteudo=11687>. Acesso em: 16 nov. 2007.

109. MORAES e SILVA, Maurício. Amazon começa a vender música digital pela internet. O Estado de São Paulo, São Paulo, 01 out. 2007, Caderno Link, p.L3. 
110. MORAES e SILVA, Maurício. Porque a música digital custa tão caro no Brasil?. O Estado de São Paulo, São Paulo, 01 out. 2007, Caderno Link, p.L3.

111. MORTAIGNE, Véronique. Num mercado do disco acidentado, a edição musical está com boa saúde. Tradução de NEUFVILLE, Jean-Yves. Le Monde, Paris, 29 set. 2007. Disponível em: <http://noticias.uol.com.br/midiaglobal/lemonde/2007/09/29/ ult580u2688.jhtm>. Acesso em: 1. ${ }^{\circ}$ out. 2007.

112. MORTON. David. A History of The Eight Track Tape. Disponível em: $<$ http://www.wgeneration.com/70f4.html>. Acesso em: 12 nov. 2006.

113. NATIONAL INFORMATION STANDARDS ORGANIZATION. Understanding Metadata. Bethesda: NISO Press, 2004.

114. NEGREIROS, Adriana. Tutinha. Revista Playboy, ed. 368, Nov. 2005. Entrevista.

115. NEUBAUER, Christian; HERRE, Jürgen. Digital Watermarking and its Influence on Audio Quality. Erlangen: Fraunhofer Institute for Integrated Circuits IIS, 1998.

116. NEUBAUER, Christian; HERRE, Jürgen. Advanced Watermarking and Its Applications. Erlangen: Fraunhofer Institute for Integrated Circuits IIS, 2000.

117. OMPI - Organização Mundial da Propriedade Intelectual. The WIPO Internet Treaties. Genebra: WIPO, 1999.

118. PIMENTEL, Alexandre Freire. O direito cibernético: um enfoque teórico e lógicoaplicativo. Rio de Janeiro: Renovar, 2000.

119. PEREIRA, Alexandre Dias. Informática, direito de autor e propriedade tecnodigital. Coimbra: Coimbra Editora, 2001.

120. PEREIRA, Alexandre Dias. Direitos de autor, da imprensa à internet. Revista da ABPI - Associação Brasileira da Propriedade Intelectual, n.64, p.21-28, maio/jun. 2003.

121. PEREIRA, Alexandre Dias. Música e electrónica: "sound sampling", obras de computador e direitos de autor na internet. In: Direito da sociedade da informação. Coimbra: Coimbra Editora, 2004. v.5. 
122. PIMENTEL, Alexandre Freire. O direito cibernético: um enfoque teórico e lógicoaplicativo. Rio de Janeiro: Renovar, 2000.

123. PINHEIRO, Daniel. No Brasil, taxa sobre direitos autorais para rádios online. Disponível em: <http://tecnologia.uol.com.br/ultnot/2007/04/19/ult4213u77.jhtm>. Acesso em: 27 de out. 2007.

124. PONTES DE MIRANDA. Francisco Cavalcanti. Tratado de direito internacional privado. Rio de Janeiro: José Olympio, 1935. Tomo I.

125. PONTES DE MIRANDA, Francisco Cavalcanti. Tratado de direito privado. Rio de Janeiro: Borsoi, 1956. Tomo VII.

126. PONTES DE MIRANDA, Francisco Cavalcanti. Tratado de direito privado: parte especial. Rio de Janeiro: Borsoi, 1956. Tomo XVI.

127. PONTES DE MIRANDA, Francisco Cavalcanti. Tratado de direito privado: parte especial. Rio de Janeiro: Borsoi, 1963. Tomo XLIV.

128. PONTES DE MIRANDA. José Cavalcanti. Tratado de direito privado. 3.ed. Rio de Janeiro: Borsoi, 1970. Tomo I.

129. RECORDING INDUSTRY IN NUMBERS. London: IFPI, 2007.

130. REESE, R. Anthony. Copyright and Internet Music Transmissions: Existing Law, Major Controversies, Possible Solutions. University of Miami Law Review, v.55, n.2, Jan. 2001.

131. RIAA, Record Industry American Association. Disponível em: <http://www.riaa.org/ faq.php>. Acesso em: 2 nov. 2007

132. ROCHA, Maria Victoria. Multimédia e direito de autor: alguns problemas. 1996.

Disponível em: $<$ http://www.ciberjus.net/revista/multimedia.htm $>$. Acesso em: 6 set. 2007.

133. ROSA, Dirceu Pereira de Santa. Download musical: falta definição de direitos autorais dos toques de celular. Revista Consultor Jurídico, 24 jun. 2005. Disponível em: <http://conjur.estadao.com.br/static/text/35778,1>. Acesso em: 8 out. 2007. 
134. SAMUELSON, Pamela. TOWARDS MORE SENSIBLE ANTI-CIRCUMVENTION REGULATIONS. Palestra apresentada na Financial Cryptography 2000 Conference, 2000.

135. SAMUELSON, Pamela. DRM \{AND, OR, VS.\} THE LAW. COMMUNICATIONS OF THE ACM, v.46, n.4, April 2003.

136. SANCTIS, Vittorio M. de. I soggetti del diritto d'autore. Milão: Giuffrè, 2000.

137. SANTOS, Manoel J. Pereira dos. A proteção autoral do website. Revista da ABPI Associação Brasileira da Propriedade Intelectual, n.57, p.3-9, mar./abr. 2002.

138. SANTOS, J. M. de Carvalho. Código civil brasileiro interpretado. 3.ed. Rio de Janeiro: Freitas Bastos, 1943. v.8.

139. SCHRICKER, Gerhard (Hrsg.) Urheberrecht auf dem Weg zur Informationsgesellschaft. Baden-Baden: Nomos, 1997.

140. SIDAK, J. Gregory; KRONEMYER, David E. The 'New Payola' and the American Record Industry: Transaction Costs and Precautionary Ignorance in Contracts for Illicit Services. Harvard Journal of Law and Public Policy, v.10, n.3, p.521-572, 1981.

141. SILVA NETO, Amaro Moraes e. Resgatemos os hackers. Jus Navigandi, Teresina, ano 4, n.44, ago. 2000. Disponível em: <http://jus2.uol.com.br/doutrina/texto.asp?id=1831>. Acesso em: 21 ago. 2007.

142. SILVA NETO, Amaro Moraes e. O spam à luz do direito brasileiro (uma visão geral). Disponível em: <http://www.internetlegal.com.br/artigos/>. Acesso em: 9 ago. 2007.

143. SOCINPRO - Sociedade Brasileira de Administração e Proteção de Direitos Intelectuais. Disponível em: http://www.socinpro.org.br/piratinternet.htm>. Acesso em: 9 ago. 2007.

144. SOUZA, Carlos Fernando Mathias de. Informativo jurídico "O neófito". Disponível em: <http://www.neofito.com.br/artigos/art01/civil57.htm>. Acesso em: 4 jun. 2006. 
145. STAUT JÚNIOR, Sérgio Said. Percurso e crise dos direitos autorais: uma leitura crítica da expressão patrimonial e do conteúdo moral. 2002. Dissertação (Mestrado em Direito) - Setor de Ciências Jurídicas - Universidade Federal do Paraná, Curitiba, 2002.

146. TEIXEIRA, Fernando. Novas tecnologias são novo alvo de cobrança do Ecad. Valor Econômico, São Paulo, 22 ago. 2007, Caderno Legislação \& Tributos.

147. THÉBERGE, Paul. Technology, Creative Practice and Copyright. In: FRITH, Simon; MARSHALL, Lee (Orgs.). Music and Copyright. 2.ed. Edimburgo: Edinburgh University Press, 2004.

148. UBERTAZZI, Luigi Carlo. I diritti d'autore e connessi. 2.ed. Milão: Giuffrè Editore, 2003.

149. UCKMAR, Victor. Introduzione. In: . Corso di Diritto Tributário Internazionale. II edizione. Padova: CEDAM, 2002.

150. VIANNA, Hermano. A música paralela. Folha de São Paulo, São Paulo, 12 dez. 2003, Caderno Mais!, p.10 e 11.

151. VILLALBA, Carlos Alberto; LIPSZYC, Delia. EI derecho de autor en la Argentina. Buenos Aires: La Ley, 2001.

152. VOSS JUNIOR, José; PÉRICAS, Francisco Adell. Compartilhamento de informações entre computadores através da tecnologia Peer-to-Peer (P2P) usando a plataforma JXTA. Artigo apresentado no XIII Seminário de Computação da FURB. Disponível em: <http:/www.inf.furb.br/seminco/2004/artigos/102vf.pdf>. Acesso em: 10 dez. 2007.

153. WEBB, William. Análise: celular do futuro será controle remoto da vida. Disponível em: <http://noticias.uol.com.br/bbc/2007/01/10/ult2363u9035.jhtm>. Acesso em: 7 out. 2007.

154. WEBER, Raul Fernando. Criptografia contemporânea. Porto Alegre: UFRGS, 1998. Disponível em: <http://www.inf.ufsc.br/ mauro/curso/redes/cripto.doc>. Acesso em: 22 ago. 2007. 
155. WIENER, Norbert. Cibernética; ou, contrôle e comunicação no animal e na máquina. Trad. Gita K. Ghinzberg. São Paulo: Polígono e Universidade de São Paulo, 1970.

156. WIKIPÉDIA. Desenvolvido pela Wikimedia Foundation. Apresenta conteúdo enciclopédico. Disponível em: $<$ http://pt.wikipedia.org/w/index.php?title= Advanced_Audio_Coding\&oldid=7045825>. Acesso em: 9 ago. 2007

\section{Sites consultados:}

$<$ http://eur-lex.europa.eu/LexUriServ/LexUriServ.do?uri=CELEX:22000A0411(02):PT:HTML>. Acesso em: 19 ago. 2007.

$<$ http://eur-lex.europa.eu/LexUriServ/LexUriServ.do?uri=CELEX:22000A0411(01):PT:HTML>. Acesso em: 19 ago. 2007.

<http://europa.eu/pol/infso/overview_pt.htm>. Acesso em: 13 nov. 2007.

$<$ http://europa.eu/scadplus/leg/pt/lvb/126053.htm>. Acesso em: 7 jun. 2007.

$<$ http://homes.eff.org/ barlow/Declaration-Final.html>. Acesso em: 5 mai. 2007.

$<$ http://mashable.com/?p=1528>. Acesso em: 1. ${ }^{\circ}$ out. 2007.

$<$ http://musicdownloads.walmart.com/catalog/servlet/MainServlet>. Acesso em: 9 ago. 2007.

$<$ http://musicsearch.myspace.com/index.cfm?fuseaction=music.search $>$. Acesso em:

1. ${ }^{\circ}$ out. 2007.

$<$ http://nickciske.com/tools/binary.php>. Acesso em: 5 maio 2007.

<http://pt.wikipedia.org/wiki/Imagem:DRM_Is_Killing_Music.png>. Acesso em: 24 ago. 2007.

$<$ http://sonora.terra.com.br/help/ajuda_comoouvir.htm>. Acesso em: 19 ago. 2007.

$<$ http://stcmegastore.uol.com.br/ajuda/ajuda-84.jhtm>. Acesso em: 19 ago. 2007.

$<$ http://tramavirtual.uol.com.br/>. Acesso em: 14 out. 2007. 
<http://www.abpd.org.br/pirataria_dados.asp>. Acesso em: 14 jan. 2007.

$<$ http://www.apple.com/itunes/store/>. Acesso em: 9 ago. 2007.

<http://www.apple.com/legal/itunes/ww/>. Acesso em: 9 ago. 2007.

$<$ http://www.correiodobrasil.com.br/noticia.asp?c=108331>. Acesso em: 7 out. 2007.

$<$ http://www.cultura.gov.br/blogs/direito_autoral/?p=10>. Acesso em: 9 dez. 2007.

$<$ http://www.cultura.gov.br/blogs/direito_autoral/?p=11\#more-11>. Acesso em: 9 dez. 2007.

$<$ http://www.dw-world.de/ dw/article/0,2144,971608,00.html>. Acesso em: 12 nov. 2006.

$<$ http://www.ecad.org.br/ViewController/publico/conteudo.aspx?codigo=16>. Acesso em: 8 out. 2007.

<http://www.eureka.be/about.do>. Acesso em: 4 abr. 2007.

$<$ http://www.fraunhofer.de/fhg/EN/company/science/Joseph_von_Fraunhofer_Preis_2004. jsp>. Acesso em: 18 ago. 2007.

<http://www.iis.fraunhofer.de/EN/bf/amm/projects/mpeg/index.jsp>. Acesso em: 9 ago. 2007.

$<$ http://www.imusica.com.br/Ajuda.aspx?Id=52>. Acesso em: 19 ago. 2007.

$<$ http://www.imusica.com.br/Corp.aspx?f=QuemSomos>. Acesso em: 10 ago. 2007

$<$ http://www.imusica.com.br/TermosDeUso.aspx>. Acesso em: 19 ago. 2007.

<http://www.internetlegal.com.br/projetos/camara/>. Acesso em: 9 ago. 2007.

<http://www.iso.org/iso/en/ISOOnline.frontpage>. Acesso em: 16 ago. 2007.

$<$ http://www.last.fm>. Acesso em: 1. ${ }^{\circ}$ out. 2007.

$<$ http://www.licensing.philips.com/information/cd/audio/>. Acesso em: 10 dez. 2006.

$<$ http://www.microsoft.com/windows/windowsmedia/forpros/drm/default.mspx $>$. Acesso em: 24 ago. 2007. 
<http://www.napster.com/about_napster.html>. Acesso em: 10 December 2007.

$<$ http://www.odisseiadosom.com.br>. Acesso em: 10 out. 2007.

$<$ http://www.piratpartiet.se/international/english>. Acesso em: 25 nov. 2007.

$<$ http://www.piratpartiet.se/international>. Acesso em: 25 nov. 2007.

$<$ http://www.pp-international.net/>. Acesso em: 25 nov. 2007.

$<$ http://www.pp-international.net/forum/viewtopic.php?t=1028\&sid=3e6f2915a3a

74019db0fdbf4530d0a4a. Acesso em: 25 nov. 2007.

$<$ http://www.research.philips.com/newscenter/dossier/optrec/index.html>. Acesso em: 29 nov. 2006.

$<$ http://www.sony.net/Fun/SH/1-20/h5.html>. Acesso em: 29 nov. 2006.

$<$ http://www.soundexchange.com>. Acesso em: 27 out. 2007.

$<$ http://www.thecommonwealth.org/Internal/20596/about_us/. Acesso em: 16 ago. 2006.

$<$ http://www.theregister.co.uk/2006/06/07/bpi/>. Acesso em: 19 nov. 2006.

<http://www.universalmusic.com.br/quemsomos.asp>. Acesso em: 12 nov. 2006

<http://www.wipo.int/meetings/en/2007/sem_cr_ge/>. Acesso em: 19 ago. 2007.

$<$ http://www.wipo.int/treaties/en/ip/rome/summary_rome.html>. Acesso em: 11 nov. 2006.

http://www.wipo.int/treaties/en/ip/berne/summary_berne.html>. Acesso em: 28 maio 2006. 